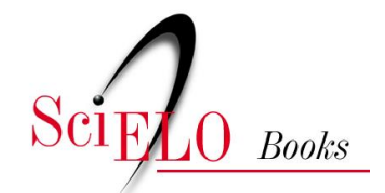

\title{
Agricultura, cooperativas e multinacionais
}

\author{
Odacir Luiz Coradini \\ Antoinette Fredericq
}

CORADINI, OL., and FREDERICQ, A. Agricultura, cooperativas e multinacionais [online]. Rio de Janeiro: Centro Edelstein de Pesquisas Sociais, 2009. 193 p. Agricultura, cooperativas e

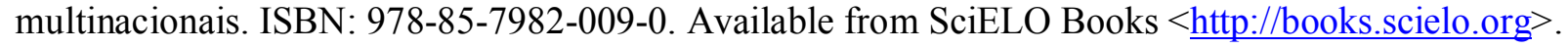

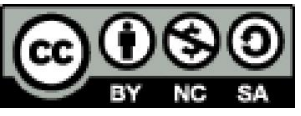

All the contents of this chapter, except where otherwise noted, is licensed under a Creative Commons Attribution-Non Commercial-ShareAlike 3.0 Unported.

Todo o conteúdo deste capítulo, exceto quando houver ressalva, é publicado sob a licença Creative Commons Atribuição Uso Não Comercial - Partilha nos Mesmos Termos 3.0 Não adaptada.

Todo el contenido de este capítulo, excepto donde se indique lo contrario, está bajo licencia de la licencia Creative Commons Reconocimento-NoComercial-CompartirIgual 3.0 Unported. 


\section{BIBLIOTECA VIRTUAL DE CIÊNCIAS HUMANAS}

\section{AGRICULTURA, \\ COOPERATIVAS E \\ MULTINACIONAIS}

\section{Odacir Luiz Coradini Antoinette Fredericq}

centro edelstein de pesquisas sociais www.centroedelstein.org.br 
Odacir Luiz Coradini

Antoinette Fredericq

\section{Agricultura, cooperativas e multinacionais}

\author{
Centro Edelstein de Pesquisas Sociais \\ www.centroedelstein.org.br \\ Rua Visconde de Pirajá, 330/1205 \\ Ipanema - Rio de Janeiro - RJ \\ CEP: 22410-000. Brasil \\ Contato: bvce@centroedelstein.org.br
}

parte desta publicação pode ser reproduzida ou transmitida por per comunicação para uso comercial sem a permissão escrita proprietários dos direitos autorais. A publicação ou partes dela podem ser reproduzidas para propósito não-comercial na medida em que a origem da

ISBN 978-85-7982-009-0 


\section{Sumário}

Apresentação

Produtores, cooperativismo empresarial e multinacionais: o caso do trigo e

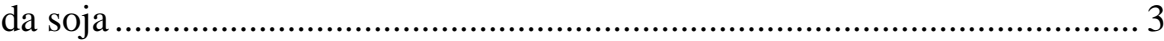

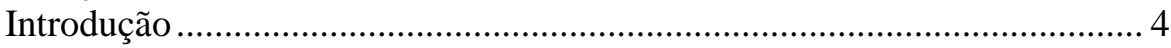

1 Formação e evolução histórica da estrutura agrária da região ..................... 7

1.1 A formação da estrutura agrária do Sul do Brasil............................... 7

1.2 A transformação da estrutura agrária................................................. 13

1.3 A produção de trigo e soja e a integração da produção agrícola ....... 23

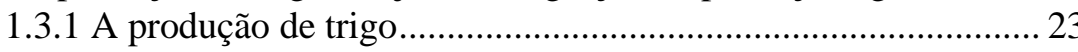

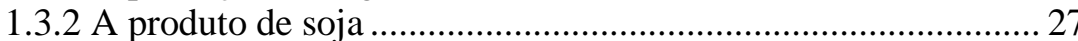

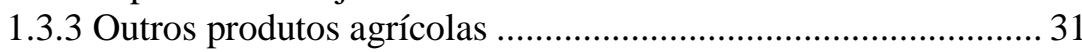

2 Complementaridade, antagonismo e articulação: O Capital Multinacional,

o Estado e as Cooperativas no Padrão de Acumulação e Dominação Social

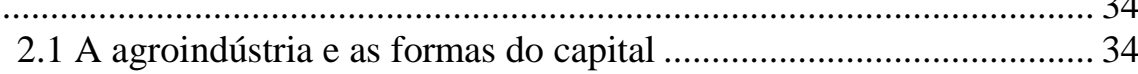

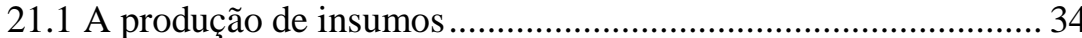

2.1.2 Comercialização e processamento da produção agrícola ........... 41

2.2 A atuação do Poder Público e das cooperativas agrícolas .................. 52

2.2.1 O Estado e a orientação e coordenação do processo de produção

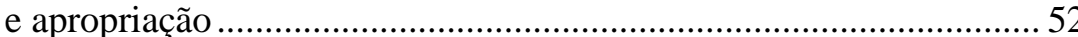

2.3 O cooperativismo como agente de viabilização econômico-política

do capitalismo associado-dependente......................................................5 59

2.3.1 Configuração geral do cooperativismo agrícola no Brasil ......... 61

2.3.2 Integração da agricultura e transformação do cooperativismo agrícola.

.... 63

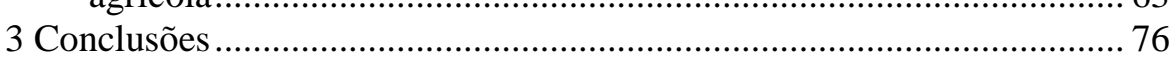

A "Babá" dos Brasileiros: uma multinacional no setor leiteiro ..................... 88

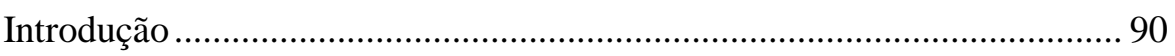

Subordinação da agricultura ao capital industrial e financeiro................ 90

O capital estrangeiro na agricultura brasileira .......................................... 93

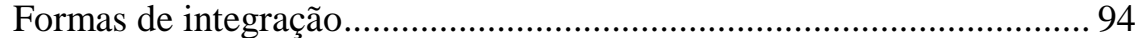

Concentração e origem do capital no "ciclo do leite" ............................. 96

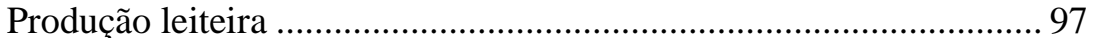

O produtor no "price-cost squeeze" ................................................... 98

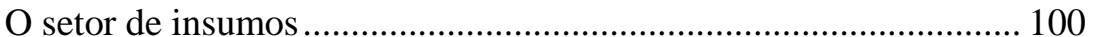

Transformação industrial .................................................................... 103

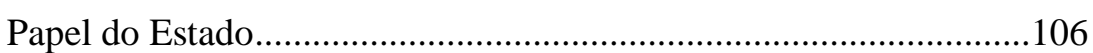

Importância da Nestlé no "ciclo do leite" brasileiro ...............................107

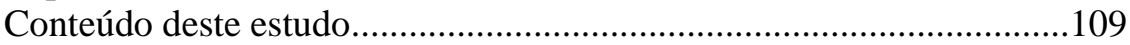

1 A Nestlé: empresa líder do setor alimentício brasileiro............................110

1.1 No caminho da diversificação ......................................................111

1.2 Primeira empresa alimentícia brasileira ............................................113

1.3 Estrutura financeira do grupo suíço no Brasil ...................................119

1.4 A Nestlé no setor de derivados leiteiros ...........................................123

2 A empresa e seus fornecedores de leite .........................................................126

2.1 Algumas reflexões sobre a persistência da produção familiar no

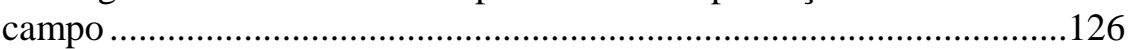

2.2 Apropriação do sobretrabalho camponês pelo capital e estratégias das grandes empresas alimentícias ..........................................................128

2.3 Capital transnacional e produção agropecuária................................129

2.4 Implantação e consolidação das fábricas de leite Nestlé..................131

2.5 Assistência Nestlé aos produtores de leite .......................................132

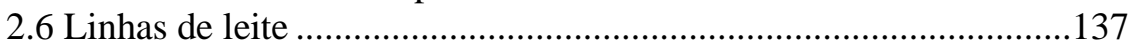

2.7 A Nestlé, os produtores e suas cooperativas ...................................138

2.8 A empresa em Três Corações..........................................................143

2.9 Os fornecedores da fábrica de Três Corações ...................................146

2.10 Tendência migratória da Nestlé no Brasil .......................................151

3 O leite em pó na ideologia dominante: a luta do seio contra a mamadeira

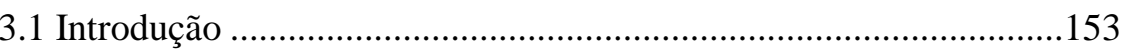

3.1.1 O seio perdeu a primeira partida ...............................................153

3.1.2 Perigos da alimentação artificial ...............................................154

3.1.3 Na luta entre o seio e a mamadeira, o árbitro é a ideologia .....156

3.2 Por que as mães brasileiras estão abandonando o aleitamento natural?

.

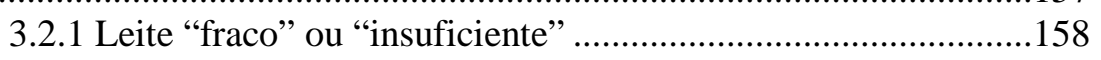

3.2.2 Classes sociais, expansão do capitalismo e diminuição da

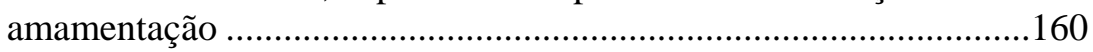

3.2.3 A mamadeira dá "status" .........................................................162

3.3 ... E as empresas de leite em pó modificado para crianças?...............163

3.3.1 O "matador de bebês" ...........................................................163

3.3.2 Mudança de tática ......................................................................165

3.4 A ideologia da comunidade de interesses......................................165

3.4.1 "A Serviço dos profissionais de saúde" .....................................166 
A Nestlé e os médicos pediatras 166

A Nestlé e as mães. 169

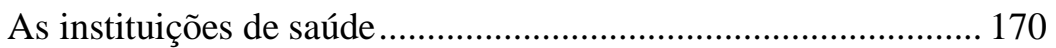

3.4.2 Interesses econômicos e missão humanitária ............................ 171

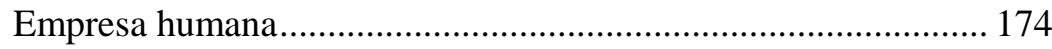

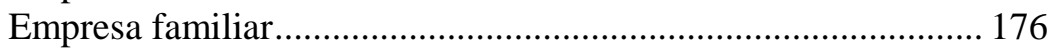

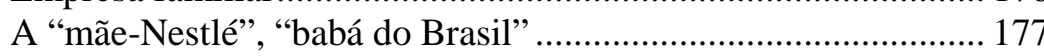

3.5 Publicidade: análise de alguns mecanismos utilizados.................... 178

4 Conclusão .

Bibliografia citada...

\section{Apresentação}

Até fins da década de 1960, os estudos rurais no Brasil eram orientados pelas teorias que localizavam no latifúndio o entrave central ao desenvolvimento capitalista no campo, ou, inversamente, que consideravam o modo de produção capitalista dominando as relações sociais na agricultura. Em época recente, esses paradigmas foram geralmente postos de lado para enfatizar a problemática da penetração do capitalismo na agricultura e, em particular, as formas através das quais a agricultura tradicional favorece a acumulação de capital.

Em torno desses problemas, foram produzidos sem dúvida estudos importantes para a compreensão da formação e dinâmica do capitalismo brasileiro, porém os termos desse debate mostram insuficiências cada vez mais aparentes no que se refere à capacidade de explicar a dinâmica social e a configuração da estrutura de classes da agricultura brasileira. Para avançar nessa caracterização, devem-se explicitar e determinar tanto os mecanismos e formas concretas através dos quais os diversos tipos de capitais "penetram" na agricultura quanto à especificidade das relações sociais existentes no campo e seu papel como agente ativo nesse processo.

É preciso deixar de lado, portanto, discussões semânticas sobre a "natureza" da subordinação do produtor familiar ao capital para desenvolver estudos concretos que permitam determinar as características do processo de formação de classes na agricultura. Nesse contexto as atuais teorizações deverão reconhecer sua precariedade, de forma que, servindo para orientar novas pesquisas, possam ser reformuladas à luz dos resultados destas.

São necessários, portanto, estudos críticos de casos específicos que permitam esclarecer os processos de diferenciação social, de subordinação agroindustrial, de integração e luta que se dão dentro da diversidade da paisagem social do campo brasileiro. É nessa perspectiva que se inscrevem os dois estudos apresentados neste livro. Fruto de pesquisas realizadas nos anos de 1977 e 1978, estes estudos são uma síntese dos resultados apresentados nas dissertações de mestrado defendidas no Departamento de Ciência Política da Universidade Federal de Minas Gerais. 
O trabalho de Luiz Coradini é um esforço de compreensão do papel das cooperativas no processo de expansão da produção do trigo e soja no Sul do país e o desenvolvimento da estrutura social sob o impacto de uma capitalização e tecnificação aceleradas da produção. É particularmente interessante o seu argumento em torno da inexistência de um processo de proletarização que acompanharia o processo de modernização agrícola, assim como a análise das grandes cooperativas como espaço contraditório de reprodução do capital agroindustrial.

Diferentemente do estudo de Coradini, a análise do processo de produção, comercialização e transformação do leite, realizada por Antoinette Fredericq, centra-se particularmente no desvendamento das formas de atuação e expansão de uma empresa agroindustrial, no caso, a Nestlé. O trabalho privilegia particularmente o que pode ser denominado a "ideologia agroindustrial", que procura substituir produtos tradicionais de consumo por outros manufaturados, geralmente de preços mais altos e menor valor nutritivo.

Abordando aspectos diferentes, os dois estudos focalizam mecanismos de interpenetração crescente entre o capital agroindustrial e os produtores rurais, as estratégias que os diversos agentes utilizam e o papel das cooperativas dentro desse complexo jogo de forças. Nesse sentido, estes trabalhos ocupam lugar importante como exemplo de estudos concretos capazes de iluminar a dinâmica social da agricultura brasileira na atualidade.

Bernardo Sorj

Belo Horizonte, novembro de 1980

\section{Produtores, cooperativismo empresarial e multinacionais: o caso do trigo e da soja}

O. L. Coradini 


\section{Introdução}

Abordamos no presente trabalho a dinâmica da articulação entre as transformações da estrutura agrária, o cooperativismo empresarialmente desenvolvido e sua inserção no padrão de acumulação e dominação social. Procuramos explicitar a dinâmica social e política da qual as cooperativas agrícolas, em especial as vinculadas à produção de trigo e soja no Sul do Brasil, fazem parte.

Como não se trata de enfocar as cooperativas em si, mas o contexto social de que resultam e onde se integram e atuam, torna-se central neste trabalho a especificidade da expansão do capitalismo na agricultura, nas condições históricas em questão. Por isso, a primeira parte é uma tentativa de apreender a estrutura de classes decorrente da penetração do capitalismo na agricultura e das novas formas de suas conexões com a sociedade capitalista como um todo.

Na parte seguinte procuramos situar às organizações e instituições através das quais se viabiliza a expansão do capitalismo na agricultura, sua reprodução geral e sua articulação com o capitalismo internacional. Entre essas organizações e instituições destacam-se o Estado, a agroindústria e o cooperativismo empresarialmente desenvolvido.

Tratamos do avanço do capitalismo na agricultura em condições históricas específicas. Por isso, as condições não são as mesmas do capitalismo em geral ou mesmo do capitalismo na agricultura em outros contextos históricos. Por isso, no presente trabalho é central o problema da pequena produção agrícola e sua manutenção, readaptação e consolidação com o desenvolvimento das forças produtivas e, consequentemente, o problema das formas e tipos de relações de produção resultante.

${ }^{1}$ Este trabalho resultou da adaptação da tese de mestrado em ciência política - "Estrutura agrária, classes sociais e cooperativismo no Sul do Brasil" —, apresentada ao Departamento de Ciência Política da UFMG em 1979, sob a orientação do professor Bernardo Sorj. Para sermos sintéticos, subtraímos aqui as referências teóricas e as evidências empíricas mais detalhadas.
Não se trata de, a priori, estabelecer a transformação de relações de produção não tipicamente capitalistas, como "trabalho familiar", em relações assalariado-comprador de força de trabalho. O que está em questão é como o capital, ao envolver a produção agrícola, mesmo onde a produtividade física do trabalho se apresenta altamente desenvolvida, mantém e consolida o "trabalho familiar", ao mesmo tempo em que transfere excedentes, exclui e marginaliza a mão-de-obra excedente etc. Em síntese, o que está em questão é a diversidade de formas de o capital incorporar diversas relações sociais, apropriar-se dos excedentes e reproduzir a dominação social.

Quanto ao cooperativismo agrícola empresarialmente desenvolvido, tentamos detectar como a expansão do capital e a reprodução da dominação social se servem de organizações específicas e como essas organizações, por força da própria dinâmica social, se enquadram e se articulam com esse processo, atuando no sentido da complementação do capitalismo associadodependente e do Estado autoritário. Portanto, enfocamos essa forma de cooperativismo enquanto articulador do processo de transformação da estrutura agrária de onde resultam as classes e camadas sociais especificamente agrícolas que lhe dão suporte social e político, com as políticas estatais e com o capital em geral e agroindustrial em especial, predominantemente sob o controle do capital externo ou do grande capital nacional. Por isso, procuramos detectar não só o relacionamento do cooperativismo com o capital transnacional e as demais formas de capital naqueles setores em que as cooperativas atuam, mas também as alianças e fricções de classe e agentes sociais que lastreiam esse relacionamento. Cabe explicitar, entretanto, que não se trata de buscar, no relacionamento entre cooperativas e outras formas de capital, uma luta entre dois modos de desenvolvimento socioeconômico — onde o capital nacional apareceria como vítima da rapina internacional - mas formas de capital em articulação, concorrência e complementaridade na emergência e consolidação do capitalismo associado-dependente. A ênfase ao capital transnacional justifica-se pelo poder dessa forma de capital em impulsionar e moldar o avanço do capitalismo associado-dependente, isto é, pela sua maior potencialidade enquanto capital com interesses específicos e não pela sua nacionalidade. 
Trata-se de uma produção agrícola em que a "produção familiar" é a base histórica de sua formação. Porém, a própria expansão do capitalismo a recria, redimensiona e transforma a produção agrícola à qual se vincula o cooperativismo em questão. Por isso, nosso enfoque está apoiado em especial em trabalhos teóricos recentes que tentam explicar a permanência e mesmo o crescimento da "pequena produção agrícola familiar" nos países de capitalismo central. Portanto, é basicamente a partir de autores como, em especial, Servolin e num grau menor Susan e Dickinson, Vergopoulos etc., que implícita ou explicitamente tentamos elaborar o corpo de ideias e conceitos de que nos servimos para a explicação do processo de transformação da estrutura agrária e formação de classes sociais na agricultura em questão. ${ }^{2}$

Partimos do pressuposto de que a dinâmica da expansão do capitalismo é definida essencialmente por forças exógenas à agricultura em si, que têm na produção industrial da grande empresa seu polo dominante. Desse modo, após delinearmos as características básicas do processo de formação histórica da estrutura fundiária e agrária e suas transformações através da integração e subordinação da produção agrícola ao capitalismo em geral, explicitamos o lugar do cooperativismo agrícola nesse processo e sua articulação com os demais agentes e forças sociais que envolvem a agricultura, em especial suas relações, concorrências e complementaridade com o grande capital externo. Na última parte procuramos demonstrar as alianças de classes e a complementaridade que se estabelecem entre o cooperativismo empresarialmente desenvolvido e a intervenção do Estado tanto no tocante à busca da racionalidade econômicoprodutiva quanto da mediação política por parte do Estado e das classes sociais em que se apoia, através dessa forma de cooperativismo. Tomamos como marco empírico básico o cooperativismo vinculado à produção de trigo e soja no Sul do Brasil, que serve de modelo para o tipo de cooperativismo em questão.

2 Ver Servolin, Claude, "L'absorption de l'agriculture dans le mode de production capitaliste", in Cahiers de la Fondation Nationale des Sciences Politiques, 184; L'univers politiques des paysans. Paris; Fondation Nationale des Sciences Politiques, 1972; Susan, A. e Dickinson, James M., "Obstacles to the development of a capitalist agriculture", in The Journal of Peasant Studies, 5 (4). Londres, julho de 1978; Vergopoulos, Kostas, "Capitalism and peasant productivity", in The Journal of Peasant Studies. Londres, julho de 1978; "Capitalismo disforme (o caso da agricultura no capitalismo)", in Amim, S. e Vergopoulos, K., A questão agrária e o capitalismo. Rio, Paz e Terra, 1977. Para uma discussão da bibliografia teórica em geral e brasileira referente à questão, ver a primeira parte de nosso trabalho supracitado.

\section{Formação e evolução histórica da estrutura agrária da região}

Procuramos a seguir delinear as bases históricas gerais em que se deu a ocupação do solo e a formação da estrutura fundiária do Sul do Brasil e as transformações pelas quais passa a estrutura agrária na medida em que a produção agrícola se incorpora de maneira mais estreita à produção capitalista em geral e agroindustrial em especial. Desse modo, num primeiro momento tentamos caracterizar a formação da estrutura agrária e fundiária em sua especificidade em relação à estrutura fundiária brasileira em geral, para, a seguir, explicitar as tendências básicas no tocante à sua evolução e às relações de produção. Na seção seguinte traçamos as linhas gerais do contexto macroeconômico em que se desenvolve a produção agrícola, em especial de trigo e soja, carros-chefe do tipo de agricultura e cooperativismo em questão.

\subsection{A formação da estrutura agrária do Sul do Brasil}

A formação e a consolidação da pequena propriedade rural nos três Estados do Sul do Brasil devem-se sobretudo à imigração estrangeira. O caráter específico da integração dos Estados do extremo sul desde o período colonial até a Revolução de 1930 fez com que a imigração para esses Estados fosse decorrente de outros fatores e tivesse resultados diferentes de outros Estados, como São Paulo. Enquanto a imigração estrangeira para São Paulo visava basicamente o suprimento de mão-de-obra para a lavoura cafeeira, que passaria a substituir a mão-de-obra escrava, para os Estados do extremo sul a finalidade básica da imigração era a ocupação efetiva do solo e sua defesa da fronteira com os países do Prata. ${ }^{3}$

A história da ocupação do solo sulino proporcionou o surgimento de suas duas faces básicas: de um lado, a grande propriedade fundiária, resultado da ocupação dos campos limpos através da concessão de sesmarias e, de outro, a pequena propriedade familiar, a partir da imigração. $\mathrm{Se}$, nas demais regiões brasileiras, a pequena propriedade familiar podia constituir-se em ameaça para o latifúndio, no Rio Grande do Sul e nos Estados sulinos em geral esse problema tem características próprias. A

${ }^{3}$ Lando, Aldair M. e Barros, Eliane C., A colonização, alemã no Rio Grande do Sul. Porto Alegre, Movimento, 1976, pp.40-41. 
pecuária extensiva e a produção de charque - ou seja, a produção da grande propriedade fundiária no Sul - não requeriam o mesmo volume de mão-deobra da produção cafeeira, e a produção agrícola das "colônias" de imigrantes nada teria em comum com a produção dos grandes estabelecimentos. Enquanto as "colônias" se dedicavam à policultura, com base no trabalho familiar (a própria legislação proibia o uso do trabalho escravo nas "colônias"), as estâncias possuíam sua base econômica na pecuária extensiva e na produção de charque, ocupando os campos limpos, com base no trabalho escravo ${ }^{4}$ (e mais tarde no trabalho assalariado).

$\mathrm{O}$ exposto anteriormente e o relativo fracasso da tentativa oficial de ocupação efetiva do solo no Sul através da imigração açoriana fizeram com que existissem duas correntes de imigração para o Brasil, quanto aos objetivos, à iniciativa e ao sistema de produção. Uma, visando basicamente a instituição da pequena propriedade, teve como suporte principal a ação oficial, localizando-se no Sul; outra, tendo como objetivo básico a importação de braços para a lavoura cafeeira, com importante participação da iniciativa privada, localizou-se em sua maior parte em São Paulo. No Sul, onde o imigrante se fixava com fins de colonização, a pequena propriedade seria complementar à grande produção, enquanto ocupação do solo e fornecimento de bens alimentares e artesanais, que deixavam de ser economicamente importantes para o latifúndio.

Como mostraremos mais adiante, parte da área ocupada pela pecuária extensiva passou a ser paulatinamente ocupada pela lavoura, com as modificações introduzidas na produção agrícola, sobretudo a partir do desenvolvimento industrial, desde a década de 1950. Por sua vez, a pequena produção agrícola formada pela imigração estrangeira foi desde o início o ponto de partida para um processo de expansão permanente dessa forma de produção, através de sucessivos desdobramentos, para mais tarde ser gradativamente incorporada e subordinada ao capitalismo industrialfinanceiro.

\footnotetext{
${ }^{4}$ Lando, A.M. e Barros, E.C., op. cit., pp.21 e passim. Sobre a oposição e defesa da formação da pequena propriedade através da imigração no Brasil, ver também Dean, Waren, "Latifúndio y política en el Brasil dei siglo XIX", in Florescano, Enrique (org.), Haciendas, latifúndios y plantaciones en América Latina. México, Siglo Veintiuno, 1975.
}

Se a pequena propriedade rural no Sul do Brasil se configurou basicamente através da imigração estrangeira, numa primeira fase, seu desenrolar não se restringe à ação direta dessa corrente migratória. A corrente migratória vinda diretamente da Europa oscila e mesmo se interrompe, condicionada pelos movimentos socioeconômicos propulsores e pela política oficial do Governo brasileiro em relação à entrada de imigrantes. Todavia, inicia-se aqui uma outra corrente que já não tem origens diretamente na Europa, mas nas próprias "colônias". 5

Com as condições técnicas e sociais da produção agrícola encontradas, os imigrantes foram forçados a abandonar suas técnicas de produção a fim de se adaptarem às novas condições socioeconômicas, passando a utilizar, por exemplo, a queima e rotação de terras. Nas condições técnicas da época, consequentemente, o tamanho dos estabelecimentos apropriados pelos colonos e o crescimento demográfico das "colônias velhas", ou núcleos iniciais de imigrantes, ofereceram um excedente populacional que passou a ocupar outras áreas, em sucessivos desdobramentos. Além disso, a Lei de Terras de 1850, segundo a qual as terras devolutas não poderiam ser adquiridas por outro meio que não fosse a compra, favoreceu esse processo, ainda que os preços nem sempre favorecessem o acesso a essas terras.

Esse processo ocorreu em todas as colônias, extrapolando inicialmente as fronteiras do Rio Grande do Sul e abrangendo a fronteira agrícola do Oeste catarinense e, mais tarde, do Oeste do Paraná, Mato Grosso do Sul etc. 6 Nas "colônias novas" os excedentes populacionais surgem com maior rapidez e intensidade, em boa medida graças à

\footnotetext{
${ }^{5}$ Utilizamos aqui os termos "colônia" para designar o núcleo de colonização formado por imigrantes e/ou seus descendentes, e "colonos" para designar os imigrantes e/ou seus descendentes.

${ }^{6}$ Para uma descrição geográfica e etnográfica do processo de ampliação da área ocupada pela imigração nos três Estados do Sul, ver Weibel, Leo, Capítulos de geografia tropical e do Brasil. $2^{\mathrm{a}}$ ed., Rio, IBGE, 1979, pp.225-77. Para o desdobramento desse processo no Paraná e os conflitos resultantes, ver Westphalen, Cecília et al., "Nota prévia ao estudo da ocupação da terra no Paraná moderno", in Boletim da Universidade Federal do Paraná, (7). Curitiba, 1968, pp.2-52.
} 
diminuição do tamanho dos lotes distribuídos, ${ }^{7}$ e, numa segunda fase, graças ao processo de modernização e reorganização da produção agrícola.

Os núcleos de colonização oficial e os de iniciativa privada foram as bases para o prolongamento do processo de ocupação do solo. Contudo, mesmo quando a delimitação do tamanho da propriedade não foi fixada oficialmente, em geral não ocorreu a formação de propriedades maiores, mas ao contrário. Isso porque o processo produtivo agrícola nessas condições históricas não requeria uma área superior à recebida, nem uma expansão da área cultivada pela família, nem tampouco uma divisão social do trabalho aprofundada. Em outras palavras, a expansão da ocupação do solo baseava-se na reprodução da agricultura familiar e essa reprodução não se definia pela acumulação do capital na própria agricultura e, permanecendo a estrutura produtiva enquanto tal, esta não requeria uma divisão do trabalho que fosse além da produção familiar.

Desse modo, de um lado a expansão da pequena propriedade encontrou condições na renda diferencial, visto que as novas terras incorporadas eram terras de menor valor comercial, não pela falta de fertilidade natural, mas pelo seu estado natural e pela distância do mercado. De outro, a aquisição dessas terras era feita, geralmente, por camponeses que não tinham em vista investimentos de capital, mas a aquisição de uma área suficiente para dar conta do emprego da mão-de-obra familiar pela qual eram responsáveis, em determinadas condições técnicas e sociais. A renda diferencial possibilitaria a aquisição de uma área maior que a da região de origem, salvo as exceções, ${ }^{8}$ os camponeses que imigravam eram

${ }^{7}$ Os primeiros colonos, em 1824, recebiam cerca de 77ha. Em 1851, o tamanho dos lotes foi reduzido para cerca de 48,4ha e a partir de 1889 (colônias novas), para 25ha. Ver Roche, Jean, A colonização alemã e o Rio Grande do Sul. Porto Alegre, Globo, 1969, v. 1, p.321.

${ }^{8}$ Existe também a possibilidade da apropriação de uma área relativamente grande na região a ser colonizada. Isso poderia acontecer: 1) quando o imigrante possuía uma área relativamente grande na região de origem e transferia o valor resultante de sua venda para a região de ocupação, porque o preço da terra era quase nulo na fronteira agrícola; 2) quando o imigrante se instalava numa região de transição entre o campo e a mata, havendo a possibilidade de transformar-se em pecuarista, ou 3) quando o imigrante se transformava em comerciante, moinheiro etc. e aplicava os resultados financeiros dessas operações na compra de terras. Apesar de exceções em termos puramente numéricos, esses casos são relevantes na medida em que esse pessoal se viu favorecido, mais tarde, quando essa agricultura ingressou em outros moldes de produção e a área mínima exigida para cada unidade produtiva passou a ser maior. os que não possuíam um montante de valor maior que o necessário para a aquisição de uma área apenas suficiente para a aplicação do trabalho da família na região de destino.

O processo rápida e genericamente descrito anteriormente é relevante na medida em que é responsável pela formação da estrutura fundiária da maior parte do Rio Grande do Sul, Santa Catarina e Paraná e ainda atua como um condicionante básico nas transformações da estrutura agrária. Ainda que as condições históricas e naturais variem em determinado grau no interior da própria região, desse processo resulta que a maior parte da produção agropecuária nesses Estados provém de pequenos estabelecimentos, com base no trabalho familiar. Se tomarmos a região Sul como um todo, as exceções de monta que fogem absolutamente do padrão descrito constituem-se na zona da "campanha" ou de pecuária extensiva, cuja ocupação obedeceu a outros moldes, as regiões de produção de arroz irrigado e as regiões cafeeira e pecuária no Paraná e Santa Catarina.

A partir da ocupação do solo nessas bases, foi-se configurando nas colônias uma policultura mercantil, baseada numa variedade relativamente grande de produtos agrícolas, que oscilavam ao sabor das vicissitudes da conjuntura do mercado e das condições tecnológicas e climáticas de sua produção. Contudo, ainda que a variedade de produtos agrícolas fosse grande, na realidade essa policultura sempre esteve comandada por um ou mais produtos de maior valor comercial. Ao lado dessa agricultura mercantil, apareceram os comerciantes, ${ }^{9}$ intermediando os excedentes da produção agrícola com outros mercados e importando aqueles bens de consumo não produzidos pelo artesanato das colônias, os quais tinham um relativo peso na orientação da produção agrícola.

Todavia, a simples comercialização de uma parte da produção agrícola não significou um crescimento econômico contínuo, havendo inclusive um relativo retrocesso da agricultura em todas as colônias. Isso porque, de um lado, as condições tecnológicas dessa agricultura baseada num processo rudimentar e o tamanho dos estabelecimentos não permitiam

\footnotetext{
${ }^{9}$ Segundo Roche, já citado, os comerciantes de produtos rurais nas colônias “(...) [foram] a única classe social rural que enriqueceu" nas primeiras fases da colonização, até aparecerem as indústrias, inicialmente em sua maior parte de origens artesanais, o que vai ao encontro do corpo teórico de Susan e Dickinson, já citado.
} 
um aumento constante da produtividade ou da produção, nessas condições. A própria agricultura itinerante, além de limitada pelo tamanho dos estabelecimentos, representaria um empobrecimento progressivo do solo. Por outro lado, a realização dos excedentes comercializáveis dependia de condições mais amplas, que extrapolam as colônias, como mercado, transportes, intermediação, política governamental etc. Com efeito, até os anos 1940, em períodos de certa forma diferentes para as diversas colônias, a agricultura é marcada por uma fase de estagnação e mesmo de retrocesso tanto em relação à produtividade física quanto ao desenvolvimento tecnológico. ${ }^{10}$

A retomada do crescimento da produção agrícola aconteceu basicamente a partir da década de 1940. Os principais produtos responsáveis por essa retomada e pelo início do processo de modernização da produção, numa primeira fase, foram o trigo e o arroz, e posteriormente a produção de soja. Contudo, essa rearticulação da produção agrícola através da progressiva especialização em determinados produtos é determinada por fatores que extrapolam a região e inclusive a própria agricultura em si. Entre esses fatores podem ser enumerados o novo padrão de industrialização e urbanização do país, a política governamental e o progressivo fortalecimento e diversificação agroindustrial. A produção de soja, que surgiu em bases comerciais em especial a partir da década de 1960 e que, juntamente com a produção tritícola, contribuiu para as subsequentes transformações da estrutura agrária, insere-se de certa forma nessas

\footnotetext{
${ }^{10}$ No Rio Grande do Sul, por exemplo, onde, com exceção da rizicultura, praticamente toda a produção agrícola era feita nas colônias, tomando-se como índice 100 para a produção agrícola para 1920, o mesmo se reduz para 74 em 1924, 84 em 1928, $81 \mathrm{em} 1932$ e $87 \mathrm{em}$ 1936. A partir de 1939, tomando-se globalmente o Estado com o índice 100 para 1939, o mesmo eleva-se para 162 em 1949 e 222 em 1954, isto é, um aumento de 122\% em 15 anos. Schilling, Paulo R., A crise econômica no Rio Grande do Sul: a crise agropecuária. Porto Alegre, Difusora de Cultura e Técnica, 1961, pp.27-37. Em termos de taxa de crescimento, no período de 1920-39, a média de crescimento da agricultura gaúcha foi de 0,3 . O valor bruto da produção decresceu em média $1,6 \%$ ao ano e a área Cultivada reduziu-se numa média anual de $0,2 \%$. Já no período $1939-56$, a produção aumentou em $157 \%$, numa média anual de $5,7 \%$, o valor bruto da produção teve um crescimento médio de $6,7 \%$ e a área cultivada teve um incremento de 5,7\% ao ano. De 1956 a 1968 a produção física cresceu em cerca de $4 \%$ ao ano e o valor bruto da produção em 3\%. Incra (Coordenadoria do Rio Grande do Sul), Levantamento dos recursos naturais, socioeconômicos e institucionais do Estado. Brasília, 1972 (versão preliminar), v. 2. Sobre a crise das colônias, ver também Roche, já citado.
}

condições. Mais adiante tentaremos definir o contexto socioeconômico do desenvolvimento da produção de trigo e soja, por ser a base do cooperativismo agrícola empresarialmente mais desenvolvido no Sul do Brasil.

\subsection{A transformação da estrutura agrária}

Procuraremos nesta parte explicitar as tendências básicas provocadas pelo impacto da integração da produção agrícola na estrutura agrária e na formação de classes sociais. Deter-nos-emos em especial no caso da produção de trigo e soja no Rio Grande do Sul, visto que visaremos definir o suporte social e político do cooperativismo mais desenvolvido empresarialmente, no tocante às classes sociais na agricultura stricto sensu. Para tanto, mostraremos sinteticamente a evolução da área média das unidades produtivas para depois analisarmos as tendências básicas quanto às formas de ocupação do solo e da ocupação da força de trabalho e, consequentemente, as relações de produção resultantes desse processo.

Não obstante o considerável avanço do capitalismo e a consequente integração de boa parte da produção agrícola no Rio Grande do Sul, as alterações estruturais que esse processo provoca não podem ser consideradas quantitativamente profundas. Mesmo assim, podem-se detectar em linhas gerais, no que se refere à evolução da área média ocupada de 1940 a 1975, um aumento acelerado até 1970 e um decréscimo dos estabelecimentos considerados "pequenos" (menos de 50ha); um aumento constante dos estabelecimentos "médios" (50 a 500ha) e uma relativa estabilização da quantidade de estabelecimentos "grandes", com uma diminuição gradativa dos estabelecimentos maiores em termos de área. ${ }^{11}$

\footnotetext{
${ }^{11}$ Devido ao caráter de síntese deste texto, abstraímos as evidências empíricas mais detalhadas e restringimos a explicitação em termos conceituais àquilo que consideramos absolutamente necessário ao esboço do processo de formação das classes sociais.
} 
De qualquer modo, os dados mostram que a expansão da agricultura tida como "empresarial", nessas condições históricas, não resultou na formação de grandes estabelecimentos. ${ }^{12}$

Geralmente, a literatura corrente aborda a estrutura agrária do Rio Grande do Sul em três segmentos básicos. Esses segmentos seriam a agropecuária colonial, a pecuária tradicional e a agricultura empresarial, com origens históricas e estruturas produtivas próprias. ${ }^{13}$ Todavia, tudo leva a crer que esses segmentos, submetidos aos novos moldes decorrentes da inserção da agricultura na acumulação e reprodução do capital, na fase do capitalismo oligopólico industrial, resultam tendencialmente na configuração e progressiva consolidação de uma estrutura fundiária e produtiva, que, no limite, não condiz propriamente com nenhum dos referidos segmentos, ainda que possa conter elementos de praticamente todos eles. A pecuária tradicional perde importância tanto no tocante à área ocupada quanto à formação do valor bruto da produção, na medida em que o capital e, com ele, novas formas de produção avançam; ${ }^{14}$ a agropecuária colonial, formada em condições históricas e sociais alheias às novas formas de produção, é forçada a se readaptar, dentro de seus limites, às novas

${ }^{12}$ Cabe ponderar que, para o IBGE, uma mesma propriedade pode estar dividida em vários estabelecimentos. Contudo, os dados do Incra de 1967 a 1977 confirmam a tendência esboçada pelos dados do IBGE. Conforme estes, os imóveis com área até 50ha tiveram uma pequena diminuição, passando de $87,9 \%$ para $87,3 \%$; os imóveis com área entre 50 e 200ha aumentaram de $8,6 \%$ para $9,0 \%$ e os com mais de 200 ha, que representavam $0,15 \%$ do total em 1967 diminuíram para 0,13\% em 1977. (Dados do Incra, reorganizados por Oliveira, Péricles F.L. de, Estrutura agrária e agricultura gaúcha. Porto Alegre, CEPA, 1978, Tabela 1.2.)

${ }^{13}$ Ver, entre outros, o trabalho do Incra (Coordenadoria do Rio Grande do Sul), op. cit. e da FEE - Fundação de Economia e Estatística, 25 anos de economia gaúcha. Porto Alegre, FEE, 1975, v. 3.

${ }^{14}$ Cabe declarar que não pretendemos de forma alguma que esse avanço da lavoura tida como empresarial em relação às demais formas de produção resolva por si só a questão entre o "latifúndio" e o "minifúndio" e, por extensão, o problema da "reforma agrária", espinha dorsal da maior parte das interpretações da estrutura agrária gaúcha. Pensamos que essa questão persiste, mas a questão básica em termos socioeconômicos não se situa na resistência do "latifúndio" ao avanço da "empresa rural". A questão básica é a exclusão potencial ou efetiva da maior parte da população tanto das possibilidades de qualquer trabalho produtivo quanto das demais formas de vida social. Essa questão não se resolve com a simples substituição do "latifúndio" pela "empresa rural". Por outro lado, também a manutenção da agropecuária colonial produtivamente estagnaria a fim de evitar o êxodo rural, marginalização social etc., como querem alguns, também não resolve a questão. exigências do produto em questão e das condições macrossociais que orientam a produção agrícola.

Aparentemente, o resultado lógico dessas tendências resultaria na consolidação da grande empresa rural capitalista. Contudo, esse processo está condicionado a uma série de fatores técnicos e sociais. Assim, se, por um lado, o grupo de estabelecimentos tidos como "empresas rurais" foi o segmento que mais cresceu no Rio Grande do Sul nas últimas décadas, esses estabelecimentos em geral não podem ser considerados como empresas no sentido de grande extensão de área ocupada ou do uso de trabalho predominantemente assalariado e de certa forma, nem pela remuneração do capital investido de acordo com a taxa média de lucro, a não ser em condições e conjunturas especiais.

A condição técnica que atua no sentido de não aumentar a área dos estabelecimentos é o processo produtivo agrícola que, nessas condições, não requer o aumento da área média, ao ponto de formar grandes empresas. ${ }^{15}$ Em outras palavras, a utilização dos meios de produção em forma econômica produtiva "ótima" não necessita necessariamente de um aumento da área média ocupada pelas unidades produtivas, ${ }^{16}$ (a não ser por parte das que se situam abaixo do patamar tecnicamente necessário) e, como veremos mais adiante, nem da utilização do trabalho assalariado.

As condições sociais que atuam nesse sentido são as próprias condições que, na medida em que integram em termos produtivos a agricultura com a produção industrial e/ou capitalista, em geral a subordinam socioeconomicamente. Essa subordinação da agricultura está assentada no maior desenvolvimento, acumulação e centralização do capital em setores não agrícolas, graças basicamente à maior velocidade da rotação de capital e, portanto, à maior lucratividade nessas esferas da produção.

${ }^{15}$ Nesse aspecto, em termos teóricos, apoiamo-nos especialmente no trabalho de Servolin, C., op. cit., pp.70 e passim.

${ }^{16}$ Por exemplo, a área mínima para a aquisição de um trator, com razoável aproveitamento e viabilidade econômica, na área de influência inicial da Cotrijuí (Noroeste do Rio Grande do Sul), de acordo com os cálculos da mesma, é de cerca de 40ha. A área ótima para um bom desempenho produtivo de um estabelecimento integralmente mecanizado é de cerca de $100 \mathrm{ha}$ e, no caso de ser feita a colheita por combinada automotriz do próprio estabelecimento, a área considerada ótima é de 150ha. Já a Fecotrigo, para cálculos dos custos de produção para o estabelecimento dos preços mínimos, toma como tamanho ideal estabelecimentos com área entre 90 e 180ha. 
Essa situação, mais a atuação do Estado, contribui para que os setores nãoagrícolas atuem oligopolicamente em relação à agricultura. As próprias condições sociais poderiam contribuir para a formação da empresa capitalista no sentido conceitual do termo, como padrão de desenvolvimento da produção agrícola - evidentemente, na medida em que as condições históricas propiciassem a formação de uma burguesia rural bastante forte para exigir politicamente condições para a realização da taxa média de lucro para o capital investido na produção agrícola. ${ }^{17}$ Todavia, no tocante à produção de trigo e soja e da maior parte dos produtos agrícolas no Sul do Brasil, não é este o caso.

Desse modo, o decréscimo dos estabelecimentos de maior área e o aumento dos considerados "médios" e mesmo "pequenos" são decorrentes em boa medida da própria expansão daquilo que se tem como lavoura empresarial. Com efeito, no Rio Grande do Sul, a produção de arroz, trigo e soja é tida como a lavoura empresarial, a qual na última década passou a ser o segmento mais importante em termos produtivos. Em 1972, 92,2\% dos imóveis que produziam soja possuíam menos de $100 \mathrm{ha}$, sendo responsáveis por $70 \%$ da área colhida, enquanto apenas $0,28 \%$ dos imóveis produtores de soja possuíam mais de 500ha, representando apenas $1,24 \%$ da área colhida. Por sua vez, 94,4\% dos imóveis produtores de trigo possuíam área inferior a 100ha e esses imóveis foram responsáveis por $51,6 \%$ da área colhida. Os imóveis com mais de 500 ha que produziam trigo $-0,11 \%$ do total foram responsáveis por apenas $0,5 \%$ da produção desse cereal. ${ }^{18}$ Isso evidencia que os produtos tidos como típicos da "lavoura empresarial" são produzidos, quase exclusivamente, por estabelecimentos com área inferior à média, sendo que a maior parte da produção se dá em estabelecimentos com área inferior a 100ha, tamanho que se situa pouco acima do considerado "tamanho ótimo" do ponto de vista produtivo, para esses produtos, nessas condições.

\footnotetext{
${ }^{17}$ Ver, por exemplo, em Servolin, C., op. cit., pp.47-49, a formação do "preço político" dos

cereais na França.
${ }^{18}$ Dados das Estatísticas Cadastrais do Incra, reorganizadas por Oliveira, Péricles F.L. de, op. cit., Tabela 3.4.1. Quanto à produção de arroz, em 1979, 85\% se deveram a lavouras de menos de 100 ha e apenas $0,7 \%$ a lavouras com mais de 500 ha. Ao mesmo tempo, o tamanho médio das lavouras consideradas "grandes (acima de 9ha)" foi de 84,5ha. Ver Irga, Anuário estatístico do arroz - 1979. Porto Alegre, v. 34, p.12.
}

Esses estabelecimentos têm origem tanto nas antigas unidades produtivas coloniais, quanto em áreas anteriormente ocupadas pela pecuária tradicional. Existe porém uma relativa tendência para os estabelecimentos menores serem responsáveis por aqueles produtos menos integrados e, por isso, boa parte da produção está sendo destinada ao autoconsumo. Em certos casos, eles se dedicam a produtos com processos produtivos diversos, que ex; em outros meios de produção, área mínima menor e proporcionalmente maior inversão de força de trabalho, como ocorre com a produção de fumo, hortigranjeiros, gado leiteiro, fruticultura etc. ${ }^{19}$

De qualquer modo, na medida em que parte dessas pequenas unidades produtivas estaria abaixo das condições razoáveis do ponto de vista produtivo, a tendência seria sua eliminação, como os dados parecem apontar, em especial após 1970. No entanto, essa tendência choca-se com determinadas condições sociais, como a falta de alternativas de emprego da mão-de-obra excedente, que é agravada com o esgotamento da fronteira agrícola, aumentando assim a pressão em relação à terra. Por conseguinte, em determinados períodos e regiões esses estabelecimentos crescem em número e em área ocupada.

É importante notar que, se tomar uma área de agricultura integrada, tecnicamente desenvolvida, ${ }^{20}$ além de ter sido formada historicamente sobretudo através da pequena propriedade, as tendências antes expostas ficam mais nítidas. Isto é, apenas da relativa rigidez da estrutura fundiária em relação à crescente penetração do capitalismo na agricultura, existe uma crescente adaptação da área média dos estabelecimentos às necessidades do processo produtivo, nas condições históricas em que se dá essa produção,

${ }_{19}$ Os estabelecimentos com área inferior a 50ha no Rio Grande do Sul, em 1970, foram
responsáveis por $85,5 \%$ da produção de milho, $88,3 \%$ de feijão, $88,0 \%$ de mandioca, $91,3 \%$
de batata, 92,8\% de cana-de-açúcar, $92,2 \%$ de amendoim, $92,2 \%$ de uva, $84,2 \%$ de ovos,
$62,4 \%$ de leite, $88,4 \%$ de suínos e $86,5 \%$ da produção de aves. (Cf. IBGE, Censo
agropecuário de 1970.)
20 microrregião colonial de Ijuí, por exemplo, em 1970 já possuía a razão de um trator para
47ha. É importante notar que existe uma tendência para a mecanização e uso de insumos
modernos, que começou sendo uma prática tipicamente da grande lavoura e passou a ser
progressivamente de determinados setores e linhas de produção, independentemente do
tamanho do estabelecimento. Por exemplo, de acordo com os dados do IBGE, em 1950 os
estabelecimentos com menos de 100ha possuíam apenas $18,92 \%$ dos tratores existentes no
Rio Grande do Sul. Esse percentual passou para 40,05 em 1960 e 50,80\% em 1970 . 
através da progressiva eliminação dos estabelecimentos com área abaixo do mínimo exigido e da diminuição ou eliminação progressiva dos estabelecimentos maiores.

Quanto às formas de ocupação do solo no Rio Grande do Sul, o arrendamento está associado, de um lado, à expansão da lavoura sobre áreas anteriormente ocupadas pela pecuária extensiva - que tem na renda fundiária capitalizada seu suporte — e, de outro, à readaptação das unidades produtivas do antigo campesinato às novas formas de produção. Portanto, o arrendamento está vinculado à expansão da lavoura "especializada" e integrada ao capitalismo industrial.

A produção de trigo, soja e arroz é responsável pela maior parte dos arrendamentos. Conforme estimativas “(...) as áreas arrendadas representam aproximadamente $44 \%$ da área cultivada com trigo e soja no Rio Grande do Sul". ${ }^{21}$ No caso da produção de arroz, o arrendamento representa cerca de 60/70\% da área cultivada. As lavouras arrendadas representavam 5,60\% do número total em 1960, 7,41\% em 1970, e 5,34\% em $1975 .^{22}$

Aparentemente, esse arrendamento estaria, em geral, associado a grandes empresas capitalistas, visto que está diretamente vinculado à expansão da lavoura tida como empresarial. Contudo, o número de arrendatários evoluiu de 1920 a 1970, em 11,67 vezes, enquanto a área arrendada aumentou em apenas 1,44 vezes, o que evidencia a diminuição drástica do tamanho médio dos estabelecimentos arrendados. Com efeito, conforme dados do IBGE, a área média dos estabelecimentos arrendados, que era de 107,3 ha em 1960 , decresceu para 77,41 ha em 1975 , portanto bem abaixo do que poderia ser considerado um grande ou mesmo médio estabelecimento.

Tudo leva a crer que uma boa parte desses arrendamentos estejam vinculados à readaptação do uso do solo às novas exigências do processo produtivo, em termos de área mínima, daqueles estabelecimentos do antigo campesinato. Em outras palavras, em boa medida o arrendamento resulta da necessidade de satisfazer uma área mínima, nessas condições de produção, a qual boa parte dos antigos estabelecimentos formados a partir das colônias já não satisfazem, à medida que avança o processo de mecanização.

\footnotetext{
${ }^{21}$ Fecotrigo, Trigo/soja; custos da produção 1967,1973 e 1974. Porto Alegre, 1975.
}

${ }^{22}$ Oliveira, P.F.L. de, op. cit., p.17 e Tabela 2.1
Portanto, esse tipo de arrendamento seria mais próprio das regiões ocupadas com base na pequena propriedade e em rápida modernização do processo produtivo. ${ }^{23}$ Um exemplo típico desse processo seria a área de atuação da Cotrijuí, no Noroeste gaúcho, onde $90 \%$ de imóveis são considerados "minifúndios" e ao mesmo tempo aumenta a proporção de arrendamentos, onde praticamente não existe a grande empresa rural.

Outra forma de arrendamento é a que se processa preponderantemente nas regiões antes ocupadas pela pecuária extensiva Não se trata da readaptação da antiga "estância" e/ou latifúndios a essa forma de produção agrícola. A quase totalidade desses arrendamentos para produção agrícola é feita por agricultores com origens nas colônias. ${ }^{24}$

Nas páginas anteriores apontamos as causas pelas quais o desenvolvimento produtivo e a integração da agricultura não formam necessariamente grandes unidades produtivas no que tange à área dos estabelecimentos. No que respeita às formas de ocupação da força de trabalho, tendencialmente, também não se constitui a "empresa agrícola capitalista" a não ser em casos específicos.

À primeira vista, a não-formação de estabelecimentos de grande área poderia decorrer da intensificação do capital em uma área menor. Nesse sentido, com exceção do tamanho da área ocupada, todos os demais elementos componentes de uma empresa capitalista no sentido completo desse conceito permaneceriam inalterados, em especial a proletarização do campesinato. ${ }^{25}$ Contudo, analisando-se os dados referentes à agricultura no Rio Grande do Sul, em especial nas regiões de trigo e soja, esses dados apontam no sentido inverso. Como decorrência da especificidade do processo de produção agrícola, ou seja, suas bases técnicas em relação à aplicação de tecnologia e novos meios de produção, o aumento da

${ }^{23}$ De acordo com as Estatísticas Cadastrais do Incra, no Rio Grande do Sul, em 1972, 75,5\% dos arrendamentos para fins agrícolas eram imóveis com menos de 50ha, apenas 4,4\% dos imóveis arrendados possuíam mais de 50011a e somente 14,8\% mais de 200ha.

${ }^{24}$ A produção de arroz, por sua formação histórica e por ser cultivada com irrigação e rotação de terras e em sua maior parte em áreas anteriormente ocupadas pela pecuária é um caso que foge a esses parâmetros.

${ }^{25}$ Ver Lenin, V.I., "Nuevos datos sobre las leyes de desarrollo del capitalismo en la agricultura", in Obras escogidas. Buenos Aires, Cartago, 1973, v. 2, pp.315-32 e Graziano da Silva, J.F. (org.), Estrutura agrária e produção de subsistência na agricultura brasileira. São Paulo, Hicitec, 1978, p.72 e passim. 
produtividade física do trabalho não requer necessariamente concentração de capital e divisão social do trabalho de forma aprofundada. ${ }^{26}$ Evidentemente, trata-se do processo produtivo de produções agrícolas determinadas, isto é, produção de trigo e soja em condições tanto técnicas quanto sociais específicas. Existem produções agrícolas em outras bases, as quais requerem, portanto, outro processo de trabalho. Por outro lado, esse processo produtivo deve ser definido dentro de determinadas condições sociais e, no caso em questão, na medida em que os setores não-agrícolas, em especial a produção industrial, são o locus ou eixo principal da acumulação de capital, determinados setores da produção agrícola tornamse desatraentes enquanto acumulação de capital, ainda que dinâmicos em termos puramente produtivos.

Disso decorre que a utilização de trabalho assalariado na agricultura gaúcha é proporcionalmente mínima e inclusive, em alguns períodos e setores, tende a decrescer. ${ }^{27} \mathrm{E}$ isso acontece mesmo num contexto sócioeconômico de excesso de mão-de-obra e, por isso, mal remunerada.

De acordo com os dados do IBGE, em geral o número de trabalhadores na agricultura gaúcha cresceu em números absolutos de 1.334.039 em 1960 para 1.893.935 em 1975, o que representa um aumento de $29 \%$ nesses 15 anos. Entretanto, nesse período a única categoria de trabalhadores que aumentou proporcionalmente foi a dos "responsáveis e membros não remunerados da família", que passaram de $85,18 \%$ do total em 1960 para 89,90\% em 1975; os empregados permanentes passaram de $4,41 \%$ para $4,64 \%$; os temporários, de $8,93 \%$ para $4,43 \%$, e os parceiros, de $1,04 \%$ para $0,56 \%$ no mesmo período.

Evidentemente, ao se considerar a agricultura do Estado em seu todo incluem-se várias formas de produção, em condições diversas. Porém, essa tendência se confirma se tomar uma das áreas de agricultura mais modernizada e especializada na produção de trigo e soja, isto é, a área de influência inicial da Cotrijuí. Nessa área, a mão-de-obra familiar, que representava $80,14 \%$ em 1950 - início da produção tritícola —, passou a

\footnotetext{
${ }^{26}$ Ver Servolin, C., op. cit. pp.44-54.

${ }^{27}$ É sintomático que uma das explicações mais correntes para o não-crescimento do trabalho assalariado em alguns setores da agricultura é o Estatuto do Trabalhador Rural. Implícito a essa explicação está o pressuposto segundo o qual o trabalho assalariado nesses setores somente seria economicamente viável quando seu preço estiver abaixo do salário mínimo.
}

representar 94,18\% em 1975; enquanto isso, a mão-de-obra assalariada em conjunto em 1975 atingia apenas $4,85 \% .^{28}$ Assim, é justamente nas zonas tidas como de agricultura mais empresarial que se tende a utilizar menos mão-de-obra assalariada e mais trabalho familiar. Mesmo aquele segmento da agricultura tido como empresarial não tem no trabalho assalariado sua forma básica de ocupação do trabalho. ${ }^{29}$

Quanto às formas de ocupação de mão-de-obra especificamente na produção de soja, no Rio Grande do Sul, em 1970, existiam 252.285 trabalhadores, maiores e menores de 14 anos. Destes, 95,87\% eram responsáveis e membros não-remunerados da família, 1,05\% empregados permanentes, $2,07 \%$ empregados temporários, $0,80 \%$ parceiros e $0,18 \%$ em outra condição. Na produção de trigo, na mesma época, havia um total de 159.285 trabalhadores, $85,42 \%$ de responsáveis e membros nãoremunerados da família, 7,41\% de empregados temporários, $5,80 \%$ de empregados permanentes, $0,97 \%$ de parceiros e $0,37 \%$ em outra condição. Com efeito, tanto num como noutro caso, a mão-de-obra familiar é a base. ${ }^{30}$

Desse modo, nessa forma de expansão do capitalismo na agricultura não existe lugar para o aumento do trabalho assalariado, nem para outras formas de trabalho preexistentes como meeiros, parceiros etc. Por outro lado, esse não-crescimento e, inclusive, diminuição de um contingente considerável de assalariados não resulta da falta de mão-de-obra em potencial para se proletarizar, mas da forma de integração e subordinação da produção agrícola, a qual possibilita a transferência de valor a outros setores e a transferência dos riscos naturais à agricultura, não possibilitando a realização da taxa média de lucro a não ser em condições e setores especiais. Por exemplo, em 1975, no Rio Grande do Sul, os estabelecimentos com área até 10ha remuneravam a mão-de-obra ativa com apenas $0,34 \%$ do salário mínimo regional; os com área entre 10 e $100 \mathrm{ha}$, ${ }^{28}$ Mereceria ser discutido o sentido do uso de trabalho assalariado nessas condições.
${ }^{29}$ Em 1972 , segundo as Estatísticas Cadastrais do Incra, o latifúndio por exploração utilizava
$38,34 \%$ do total de assalariados, contra $37,50 \%$ para a empresa rural, $24,10 \%$ para o
minifúndio e $0,5 \mathrm{~J} \%$ para o latifúndio por dimensão. Nesse mesmo período, entre os
trabalhadores especificamente da empresa rural, $32,08 \%$ eram dependentes do proprietário
trabalhando e $15,90 \%$ eram assalariados permanentes.
${ }^{30}$ A produção de arroz constitui exceção, por possuir tanto uma formação histórica quanto
um processo produtivo diverso, no sentido, por exemplo, de não possuir uma mecanização integral de todas as fases do processo. 
com 0,67\%; apenas os estabelecimentos com mais de 100ha possuíam uma remuneração acima do salário mínimo regional. ${ }^{31}$

Um dos reflexos sociais mais notórios disso é o processo de migração, tanto rural/urbana quanto rural/rural para a fronteira agrícola. Em outras palavras, existe um processo violento de seleção/exclusão a partir do avanço do capitalismo na produção agrícola, impulsionado pelo aumento do preço da terra e ao 4ua1 se contrapõe a falta de alternativas de emprego da mão-de-obra excedente. ${ }^{32}$

Num esboço do que parece ser a tendência básica da formação da estrutura de classes sociais decorrente do exposto acima, o aspecto básico é a progressiva formação de uma camada de "neocamponeses", cujas unidades produtivas são altamente capitalizadas e integradas à esfera de circulação e à produção industrial e com base no trabalho familiar praticamente não utilizando outra forma de trabalho. É fundamentalmente essa camada de produtores agrícolas, juntamente com a burguesia rural, que quantitativamente é insignificante, no caso, que constitui o suporte socioeconômico e político do cooperativismo agrícola mais desenvolvido empresarialmente. Ao mesmo tempo, é sobre esse processo de violenta exclusão/marginalização/transferência de sobretrabalho e suas contradições e tensões sociais que essas organizações atuam também como catalisadoras e viabilizadoras.

Simultaneamente à afirmação dessa camada de produtores, existe a progressiva deterioração do antigo campesinato em algumas regiões e setores, a transformação do latifúndio pela lavoura mecanizada, que em alguns casos convive com outras formas de ocupação da força de trabalho, como trabalho assalariado, entre outras, quantitativamente pouco significativas.

\footnotetext{
31 Dados do Rio Grande do Sul. Programa de Investimentos Integrados para o setor agropecuário do Rio Grande do Sul. Porto Alegre, 1975. Sobre a remuneração do trabalho agrícola e os excedentes de mão-de-obra, ver ainda o trabalho do Incra. Coordenadoria do Rio Grande do Sul, op. cit., v. 2

32 “(...) o saldo migratório do Rio Grande do Sul foi sucessivamente crescente: de 97.068 no período 1940-50, passou para 162.352, no intervalo $1950-60$ e atingiu 367.330 pessoas entre 1960 e 1970.” FEE, op. cit., p.71. Ver também FEE, Indicadores sociais - RS. Porto Alegre, 4 (4), 1976.
}

\subsection{A produção de trigo e soja e a integração da produção agrícola}

Procuraremos nesta parte delinear em termos gerais a evolução da produção de trigo e soja e seus condicionantes básicos. Nesse sentido, tentaremos demonstrar que a produção de trigo e soja, carro-chefe de um processo de profundas transformações na estrutura agrária e de uma nova forma de cooperativismo, está condicionada por forças sociais e agentes que extrapolam a agricultura stricto sensu. Desse modo, embora a produção tritícola e de soja se inscreva no marco de uma nova fase de relacionamento entre a agricultura, a indústria e o capitalismo em geral, ela não apresenta apenas uma expansão quantitativa notável nas últimas décadas. Esses produtos agrícolas, num primeiro momento, e outros, mais tarde, representam a introdução e progressiva consolidação de uma nova forma de produção agrícola no Sul do Brasil, em outras bases e com outro processo produtivo, agora estreitamente integrado e subordinado à agroindústria e às políticas estatais. Portanto, se de um lado a expansão dessa forma de produção atua no sentido de provocar profundas mudanças na estrutura agrária, de outro, vincula mais estreitamente a produção agrícola ao capitalismo agroindustrial, predominantemente de capital externo, e às políticas de viabilização e reprodução do capitalismo associado-dependente.

\subsubsection{A produção de trigo}

A produção tritícola, um dos principais responsáveis pela reorganização e integração da agricultura gaúcha, foi introduzida nesse Estado, em meados do século XVIII, pelos imigrantes açorianos, visando tanto sua subsistência quanto a produção para comercialização. No começo do século XIX deu-se o auge de sua produção, mas a partir de 1820 esse cereal praticamente desapareceu do Estado. As razões básicas desse desaparecimento foram os problemas de moléstias, a expansão das charqueadas devido à crise do charque platino que atraiu os açorianos para a pecuária e à abertura dos portos em 1808, com a consequente importação de farinha norte-americana. ${ }^{33}$

\footnotetext{
${ }^{33}$ Schilling, Paulo, Trigo; o trigo e o latifúndio no Rio Grande do Sul - o acordo do trigo norte-americano - perspectiva da triticultura gaúcha. Rio, M.A./ISEB, 1959, pp.16-17.
} 
O ressurgimento da produção desse cereal deu-se com a imigração italiana e alemã, na segunda metade do século passado. Contudo, apesar dos incentivos do Governo provincial e imperial, na segunda metade do século passado e durante quase toda a primeira metade deste, o trigo manteve-se como um produto essencialmente de subsistência das colônias. ${ }^{34}$

Se a produção tritícola se manteve quase estagnada até a década de 1940, a partir de 1939 até 1956 a produção assinala resultados favoráveis, ainda que oscilantes. ${ }^{35}$ Esse crescimento decorre em boa medida dos incentivos governamentais - créditos, subsídios, garantia de preços mínimos, criação de infraestrutura de comercialização, melhorias tecnológicas. É nesse período que a produção de trigo extrapola os limites das colônias, avançando sobre áreas anteriormente ocupadas pela pecuária. ${ }^{36}$ É nesse período também que, graças aos incentivos governamentais, a mecanização da produção tritícola começa a provocar mudanças aceleradas na estrutura produtiva. Na medida em que a produção deixou de se dar exclusivamente nas colônias e avançou sobre outras áreas, transformando a antiga estrutura produtiva, a lavoura tritícola começou a se diferenciar. Não que a produção passasse a se dar exclusiva ou predominantemente em bases empresariais, mas na medida em que a triticultura passou a ser incentivada, passou a haver e a se consolidar um segmento de produtores especializados. Esse segmento, que inicialmente era constituído pelos maiores produtores, aumentou proporcionalmente ao incremento da produção e passou a ser mais tarde um fenômeno responsável por transformações paulatinas também nas colônias, na medida

\footnotetext{
${ }^{34}$ Ver Roche, Jean, op. cit. , pp.245-46.

${ }^{35}$ De 1920 a 1940, a área plantada aumentou apenas de 120.000ha para 169.517ha. Em 1958 já havia aumentado para 614.377ha, numa média anual de crescimento de aproximadamente 50.000ha no período 1940-58, ritmo só alcançado mais tarde no Rio Grande do Sul, com a produção de soja.

${ }^{36} \mathrm{O}$ interesse pela produção de trigo, principalmente na segunda metade da década de $1940 \mathrm{e}$ na segunda metade da década de 1950, atingiu também profissionais liberais, pequenos comerciantes etc., atraídos pelos incentivos governamentais. Ver Oliveira, Jorge de, Aspectos produtivos e econômicos das dez principais culturas do Rio Grande do Sul: 1948 a 1969. Porto Alegre, IEPE/UFRGS, 1971, p.64. Isso tem levado muitos a interpretarem o impulso à produção tritícola e de soja como resultado da inversão de capital de origem urbana na agricultura. Pensamos que se trata de uma confusão entre aspectos conjunturais e estruturais.
}

em que na maior parte delas o trigo - posteriormente junto com a soja passou a ser a produção hegemônica.

A partir de 1958, até 1966, as condições climáticas desfavoráveis e a mudança na política de importação de trigo - assinatura dos Acordos do Trigo com base na Public Law 480, entre 1956-57 e 1966-67 - fizeram com que com a mesma rapidez da ascensão da produção houvesse o descenso. ${ }^{37}$ Entre 1958-66 a área cultivada caiu em 39\% e entre 1958-64, em $51 \%$. Com esse declínio da produção houve uma evasão dos produtores de origem urbana e um avanço temporário da pecuária em áreas anteriormente ocupadas com produção de trigo, voltando em alguns períodos a ser as regiões coloniais os principais lugares de sua produção e onde o trigo nem sempre é o principal produto agrícola.

A partir da segunda metade da década de 1960, em especial de 1967, há uma retomada geral da produção tritícola tanto no Rio Grande do Sul quanto em termos nacionais. É a partir desse período que se consolidou a produção do trigo em outros Estados brasileiros, como é o caso do Paraná e hoje o Mato Grosso do Sul e o cerrado brasileiro. No Rio Grande do Sul, de

\footnotetext{
${ }^{37}$ Cerca de $85 \%$ do valor em cruzeiros do trigo norte-americano importado seriam emprestados ao BNDE (Banco Nacional de Desenvolvimento Econômico) e o Acordo estipulava a aprovação prévia por parte do Governo norte-americano dos financiamentos feitos pelo BNDE, ao mesmo tempo em que uma parcela fixa do total dos empréstimos seria destinada para "(...) financiamentos a empresas privadas de qualquer nacionalidade". Ver Schilling, Paulo, Trigo (...), op. cit., pp. 31-39.

É importante notar que nesse período já se delineavam algumas das bases daquilo que seria o padrão de acumulação e nele a inserção da produção agrícola, bem como da forma de produção agrícola a ser adotada. Ou seja, o tipo de agricultura representado sobretudo pelo trigo e pela soja já estava sendo articulado e gestado bem antes de 1964. De acordo com jornais do início da década de 1960, por exemplo, "750 milhões de cruzeiros vão ser destinados pela Agency for International Development dos Estados Unidos para o desenvolvimento do Sistema Brasileiro de Extensão Rural, segundo o convênio fumado no Gabinete do Ministro da Agricultura, pelos ministros Armando Monteiro Filho, embaixador Lincoln Gordon (...) e diretor da AID no Brasil, ministro Leonard Saccio.

"O acordo tem em vista o desenvolvimento de projetos para o desenvolvimento da produção agropecuária, no Brasil (...) e vai ser financiada (sic) com recursos oriundos do Acordo do Trigo, dentro dos princípios da Aliança para o Progresso. Após a assinatura do convênio, a Ascar recebeu a primeira parcela desse montante, no valor de 250 milhões de cruzeiros." (Correio do Povo, Porto Alegre, 17 de março de 1962.)
} 
1966 a 1972, a área cultivada aumentou em $392 \%,{ }^{38}$ que apesar das oscilações extremamente bruscas se manteve em ascensão.

Um dos elementos presentes no incremento ou descenso da produção brasileira de trigo é a política de importação ou produção interna, condicionada, de um lado, pelas condições climáticas brasileiras relativamente adversas e, de outro lado, por uma série de relações entre agentes socioeconômicos que envolvem a grande indústria, as indústrias produtoras de insumos, os Estados nacionais etc., cuja relação de forças muda para cada momento considerado. Em termos gerais, a evolução da política de importação ou não de trigo pode ser considerada em diversas fases, tais como o período de gestação e implementação das primeiras políticas estatais no sentido de incentivo à produção interna desse cereal e tendo a Argentina como principal fornecedor; o período do pós-guerra, até o final da década de 1960, no qual os EUA surgem como potência alimentar e se estabelecem os Acordos do Trigo e quando já começa a despontar a grande indústria de processamento (Bunge y Bom) como um dos elementos básicos na determinação da política de importação; e, finalmente, o período iniciado na segunda metade da década de 1960, de incremento à produção nacional e relativa diminuição das importações no consumo.

Para esse novo impulso à produção tritícola contribuiu uma série de condicionamentos naturais e forças socioeconômicas, as quais atuam tanto num sentido quanto noutro. Entre os condicionamentos naturais merecem destaque a baixa fertilidade natural e a acidez do solo, as condições climáticas difíceis e a escassa tecnologia, que tomam o trigo produzido no Brasil relativamente custoso. ${ }^{39}$ Entre as principais forças socioeconômicas que atuam no sentido do aumento da produção estão o próprio Estado brasileiro - entre outras coisas, tentando evitar o consumo de divisas com importações - o crescimento e consolidação do complexo agroindustrial e sua integração com a produção tritícola, o grupo de pressão política que os triticultores - agora organizados em cooperativas - representam, a

\footnotetext{
38 Ver Grzybwoski, C., "O trigo no Brasil", in Notes du GEREI (2), pp.15-42, Paris, setembro de 1977. Ver também Freitas, Luiz M. e Neto, A.D., O trigo no Brasil. São Paulo, Associação Comercial, 1960

${ }^{39}$ Ver Knight, Peter T., "Substituição de importações na agricultura brasileira: a produção de trigo no Rio Grande do Sul”, in Estudos Econômicos. São Paulo, I (3), 1971, pp.92-97.
}

complementaridade entre produção de trigo e soja, além da falta de opções para cultivos de inverno.

Por outro lado, independentemente das oscilações e da discutível racionalidade estritamente econômico-produtiva da triticultura, ${ }^{40}$ interessanos aqui a consolidação dessa produção agrícola enquanto desencadeadora de um processo de transformação da estrutura produtiva e socioeconômica e integração da agricultura em questão. Nesse sentido, o próprio desenvolvimento da produção de soja está de certo modo vinculado à produção de trigo não apenas por ser complementar, mas inclusive por ter aproveitado boa parte da infraestrutura de produção e desenvolvimento tecnológico. O mesmo está acontecendo com outros produtos com processos produtivos semelhantes.

\subsubsection{A produto de soja}

Ao lado do desenvolvimento da produção tritícola, o incremento, consolidação e, posteriormente, a hegemonia da produção de soja é um dos elementos básicos, no tocante à produção agrícola, para a explicitação das transformações da estrutura social e para $o$ fortalecimento do cooperativismo agrícola em bases empresariais. Também quanto à produção de soja não nos interessa diretamente o aumento da produtividade física em si nem o montante produzido, a não ser como indicadores das condições técnicas e sociais sob as quais se dá essa produção.

Ao mesmo tempo em que a produção de soja, em especial no Rio Grande do Sul, tem muito em comum com a produção tritícola no tocante às bases técnicas e sociais da produção, foi por seu intermédio que se deu o maior avanço no sentido da integrado da estrutura produtiva agrícola às esferas da produção capitalista em geral. Portanto, ainda que ao nível macroeconômico a posição da produção de soja seja um tanto diversa da tritícola, ao nível da estrutura produtiva complementam-se inclusive no

\footnotetext{
${ }^{40}$ As posições quanto à continuidade ou não da produção tritícola nacional ainda variam desde os que advogam a autossuficiência através de estímulos oficiais e desenvolvimento tecnológico, até sua pura e simples supressão, devido aos altos custos que sua manutenção representaria para o Estado. Cabe notar que, na medida em que já existe uma série de produtos agrícolas com alto consumo de insumos industriais, esse setor industrial não faz as mesmas pressões no sentido de seu incentivo, por haver outras opções de consumo de insumos. 
sentido de articular essa estrutura produtiva com a agroindústria e as políticas estatais.

De maneira geral, o aumento da produção brasileira de soja, em especial a partir do final da década de 1960, pode ser atribuído à conjugação de uma série de fatores, entre os quais alguns podem ser considerados como decisivos: a crescente internacionalização da economia da soja - conjugado com o fato de a soja brasileira ser colhida na entressafra dos maiores produtores mundiais; a política brasileira de incentivo à sua produção e exportação; a consolidação da indústria de processamento e da agroindústria em geral; o baixo custo da força de trabalho e da terra, comparativamente aos maiores produtores mundiais; e, no caso das regiões produtoras de trigo, a complementaridade existente ao nível da produção (insumos, tecnologia, sazonalidade), comercialização (ocupando praticamente a mesma estrutura montada para o trigo, como as cooperativas) e da política de incentivos a esses dois produtos.

De qualquer modo, o crescimento tanto da produção brasileira de soja quanto da capacidade de processamento das indústrias situadas no Brasil, em especial na última década, foi acelerado. Com efeito, no período 196675, a produção mundial cresceu em 1,60 vez e a produção brasileira em 9,28 vezes. No período de $1970-77$, o crescimento foi de $800 \%{ }^{41}$

Como a produção brasileira é destinada em sua maior parte à exportação (em grão, farelo, óleo), o Brasil ocupa o lugar de segundo exportador mundial. Essas exportações acompanham o crescimento da produção, as quais representaram 2,6\% do total das divisas das exportações brasileiras em 1970 e passaram a representar 17,6\% em 1976. ${ }^{42}$ No Rio Grande do Sul, nesse ano, a soja in natura $(33,78 \%$ ), farelo e óleo de soja em bruto representaram $62,76 \%$ do total das exportações. Por outro lado, o Brasil, que importava óleo de soja, passou a exportá-lo em 1972, ainda que esse produto tenha passado a substituir outros óleos vegetais e a banha. Cerca de 70-80\% do farelo de soja são exportados. Dependendo da safra, ainda são exportados $20-30 \%$ in natura. Os principais mercados para os

\footnotetext{
${ }^{41}$ Ver Conjuntura Econômica. Rio, 30 (11), novembro de 1976, p.119 e passim, e M.A., Comissão de Financiamento da Produção. Subsídios para fixação dos preços mínimos safra 1978-79. Brasília, 1979, p.145.

${ }^{42}$ M.A., Comissão de Financiamento da Produção, op. cit., p.145.
}

produtos com base na soja ou in natura é o Mercado Comum Europeu, países da Europa em geral, URSS e Japão.

Além da alta cotação internacional da soja, que é atribuída, basicamente, ao crescimento dos rebanhos bovinos na Europa e EUA, estimulando assim o preço do farelo, à queda da produção de farinha de peixe no Peru e à entrada da URSS na importação dessa oleaginosa, ${ }^{43}$ devese levar em conta a internacionalização do complexo de processamento e comercialização da soja. Isto é, a comercialização e, em boa medida, a industrialização da soja brasileira dependem das grandes companhias ou conglomerados internacionais que não têm necessariamente interesses estabelecidos geográfica ou nacionalmente. Com efeito, as exportações norte-americanas de soja são feitas por um número relativamente pequeno de empresas, como a Continental Grain, Cargill Incorporated, Bunge y Bom, Cargill/Tradax, Louis Dreifus, European Grain and Shopping/Andre Cie, Central Soya Co., Swift \& Co., Ralston Purina, Anderson Clayton etc., quase todas atuando também na comercialização e processamento da soja brasileira, com incentivos governamentais. ${ }^{44}$ Além disso, essas empresas geralmente atuam na forma de "Trading Companies", possuindo escritórios em todo o mundo, ao mesmo tempo em que possuem unidades de processamento nos países produtores ou consumidores, além de companhias de navegação e de seguros e incluem ramos industriais e associações com grupos financeiros.

Evidentemente, não são apenas os acidentes climáticos ou as leis de mercado atuando livremente que determinam a alta do preço internacional da soja, mas forças sociais organizadas, com interesses diversos, que abrangem desde os produtores, os grupos comerciais e industriais envolvidos no circuito produção-comercialização-transformação, até os Estados nacionais onde os EUA aparecem como força maior. ${ }^{45}$

\footnotetext{
${ }^{43}$ Conjuntura Econômica, op. cit., pp.121-22.

${ }^{44}$ Ver Rio Grande do Sul. Assembleia Legislativa. Análise do $1^{\circ}$ Simpósio Nacional da Soja. Porto Alegre, Assembleia Legislativa, 1977, p.54 e passim. Ver também Rio Grande do Sul. Assembleia Legislativa. $1^{o}$ Simpósio Nacional da Soja. Porto Alegre, Assembleia Legislativa, 1976.

${ }^{45}$ Sobre as forças sociais em jogo no "complexo soja" e a dominação norte-americana do mercado, ver Berlan, J.P. et al, "Blé et soja: pénuries sur commande?", in La Recherche, (56), Paris, maio de 1975, pp.408-17.
} 
É nesse contexto que se inserem as políticas do Estado brasileiro no sentido do aumento da produção e exportação da soja. Assim, essa oleaginosa e seus derivados (óleo, farelo) passaram a representar a maior parte do consumo e comércio internacional de oleaginosas, com uma alta taxa de crescimento. Com sua política voltada para o incremento à produção para a exportação, o Brasil ocupa o segundo lugar no comércio internacional de soja e derivados, ficando a liderança com os EUA. Entretanto, ainda que os maiores importadores de soja, como os países do Mercado Comum Europeu, dependam quase que exclusivamente de importação para suprimento de suas necessidades e não possuam condições de alcançar a autossuficiência, adotam uma política protecionista que se contrapõe à política brasileira de exportação.

Assim, “(...) cada vez que um exportador colocar um produto na Europa, terá, automaticamente, de dar uma contribuição para esse fundo (de prelevements). Por exemplo, cada vez que uma tonelada de milho do Brasil atinge a Europa (sendo que o preço de orientação é de 130 dólares) estaremos contribuindo com 20 dólares para esse fundo (...)" ${ }^{46}$

Contra isso o Estado brasileiro joga com o menor custo de força de trabalho na produção de soja, se comparada internacionalmente, o menor preço de renda fundiária e a orientação de suas políticas agrícolas seletivamente, entre as quais se incluem a racionalização e subsídios à infraestrutura de produção, comercialização, processamento e exportação de soja. No conjunto das políticas de estímulo à exportação de soja e derivados, visando uma maior competitividade internacional, destacam-se a política cambial - minidesvalorizações —, reduções do ICM e estímulos e créditos fiscais que beneficiam os agentes envolvidos no processamento e exportação dessa oleaginosa. É com base nesse conjunto de forças sociais contraditoriamente entrelaçadas que o grande capital vinculado ao processamento e comercialização internacional da soja e derivados montam suas estratégias.

Alguns autores atribuem o grande crescimento da produção e exportação brasileira de soja e sua competitividade no mercado internacional à complementaridade da produção de trigo-soja (o que não acontece nos EUA, maior produtor e exportador, responsável por mais da

\footnotetext{
${ }^{46}$ Rio Grande do Sul, Ass. Legislativa, op. cit., p.90.
}

metade da produção mundial) e à renda fundiária, que é mais baixa no Brasil em relação aos EUA, além de as empresas que operam no Brasil serem praticamente as mesmas. ${ }^{47}$ Ainda que sejam elementos básicos para a exploração, o baixo custo da força de trabalho no Brasil é determinante e tem a ver inclusive com a entrada das empresas multinacionais na comercialização e industrialização da soja no próprio país. Desse modo, em 1977, os custos para a produção de soja praticamente se equivaleriam entre os EUA e o Brasil (Rio Grande do Sul), com uma pequena margem de vantagem para a produção norte-americana, a qual contava, entre outras vantagens, com um menor preço dos insumos em geral e menores custos na comercialização (pouco mais de um décimo das despesas brasileiras). Entretanto, essas vantagens ficam praticamente anuladas na medida em que a produção norte-americana tem uma despesa com mão-de-obra 3,47 vezes superior e uma despesa com renda fundiária mais de quatro vezes superior à produção brasileira. ${ }^{48}$

\subsubsection{Outros produtos agrícolas}

Como foi dito em páginas anteriores, apesar da primeira fase da agricultura nas regiões coloniais do Sul do Brasil ter sido uma policultura, essa aparente policultura sempre esteve comandada por um ou mais produtos de maior valor comercial, os quais constituem o essencial do excedente comercializável. Logicamente esses produtos variam conforme as condições de produção e a maneira pela qual a agricultura se integra ao mercado. Paralelamente a essa produção voltada para o mercado, essa forma de agricultura se encarrega de uma série de produtos para o consumo do próprio produtor. Ao mesmo tempo, nas antigas colônias a relação entre produção para o próprio consumo e para a troca é extremamente vulnerável às oscilações conjunturais do mercado, não existindo uma delimitação 'rigorosa entre produtos para consumo e para o mercado, visto que é uma produção não especializada, não tendo uma vinculação e orientação estreita por parte das políticas oficiais e mercado ao ponto de determinar

47 Ver Berlan, Jean-Pierre et al., Le complexe soja des Etats-Unis. Paris, GEREI, 1976,pp.73-74.

48 Dados brutos extraídos de M.A., Comissão de Financiamento da Produção. Preços mínimos; regiões: Centro-Oeste, Sudeste e Sul. Safra 1977-78. Brasília, 1978, p.150. 
rigorosamente os produtos e as formas de produção, inclusive porque parte dos meios de produção é produzida através do artesanato das colônias.

$\mathrm{Na}$ medida em que essa estrutura produtiva passa a ser substituída pela produção de trigo e soja e outros produtos, em outros moldes, estes passam a ser hegemônicos em determinadas regiões. Como decorrência de uma integração mais estreita da produção agrícola à agroindústria e às políticas estatais, há uma progressiva eliminação e/ou transferência espacial dos produtos agrícolas com menor valor comercial e uma progressiva eliminação da produção para autossubsistência. Em outras palavras, a formação do "produtor especializado" e a readaptação das estruturas às novas condições da produção.

Por exemplo, em algumas regiões produtoras de trigo e soja no Sul do Brasil, a composição do valor bruto da produção chegava, em 1973, a ser composta em $80 \%$ por esses dois produtos, situação notavelmente contrastante com a maior diversidade de alguns anos antes. ${ }^{49}$ Por outro lado, em 1977, no Rio Grande do Sul, a soja e o trigo ocupavam 57\% das áreas e do valor da produção e, se acrescentarmos o arroz e o milho, a área ocupada pela lavoura aproximava-se dos $90 \%{ }^{50}$

Em relação às cooperativas, esse aspecto da especialização é relevante na medida em que o cooperativismo mais empresarialmente desenvolvido, como o vinculado à produção de trigo e soja, que surgiu no bojo do incremento a essas produções, adota uma posição abertamente contrária à monocultura. Desse modo, mesmo que alguns produtos continuem hegemônicos, a tendência é uma relativa e gradativa diversificação impulsionada de certo modo pelas cooperativas até onde essas organizações têm poder de orientação da produção, o que contribui para a diversificação das atividades das cooperativas.

Contudo, essa diversificação da produção (gado leiteiro, suinocultura, fruticultura, hortigranjeiros), seja ela promovida através das cooperativas ou da agroindústria em geral, não é um retorno à antiga policultura colonial, já que é orientada e integrada à reprodução do capital. Um fator que contribui para isso é o exagero com que a política agrícola investiu na exportação,

${ }^{49}$ Dados do Convênio Incra-Unicamp. Regiões homogêneas da agricultura (mimeog.). São Paulo, 1977, p.147.

${ }^{50}$ Dados da Lavoura Arrozeira. Porto Alegre, agosto de 1977, p.11. ampliando a necessidade de produtos de consumo interno (e mesmo para exportação, além da soja).

Do ponto de vista das cooperativas, uma das razões básicas de sua atuação nesse sentido é a necessidade de uma alternativa para as massas marginalizadas pela expansão do capitalismo na produção tritícola. Nesse sentido, pelo menos ao nível político-ideológico, o cooperativismo tentaria adaptar os pequenos estabelecimentos com área insuficiente para a produção de trigo e soja àquelas produções que exijam proporcionalmente mais trabalho e menos terra e capital. 


\section{Complementaridade, antagonismo e articulação: O Capital Multinacional, o Estado e as Cooperativas no Padrão de Acumulação e Dominação Social}

Nesta segunda parte procuramos explicitar as formas básicas de conexão do cooperativismo agrícola com as demais forças sociais e agentes que envolvem e definem a produção agrícola, tendo como base social, no tocante à agricultura stricto sensu, a estrutura produtiva e de classes caracterizada na parte anterior. Buscamos situar o cooperativismo agrícola em questão tanto em relação ao capital agroindustrial e externo quanto em relação ao poder público.

\subsection{A agroindústria e as formas do capital}

\subsection{A produção de insumos}

A produção agrícola, nas condições em questão, apresenta-se como um poderoso, consumidor de insumos de origem industrial, o qual possui um poder de barganha incomparavelmente superior. Por isso, na medida em que a produção agrícola intensifica suas relações com os demais setores e agentes, entre os quais a indústria de insumos, esta aumenta sua capacidade de orientar e controlar aquela e transferir valor, pela maior concentração e centralização do capital, integração produtiva agricultura-indústria, em síntese, pela maior capacidade de impor preços tanto frente aos produtores agrícolas quanto ao Estado.

Contudo, isso não significa que a indústria de insumos (ou de transformação da produção agrícola) se apresenta de forma homogênea e linear no tocante ao grau de oligopolização, ao poder de barganha ou à participação do capital externo. No subsetor de produção de insumos e também de processamento da produção agrícola, convivem, de forma extremamente diversa para cada caso, desde as pequenas empresas de capital nacional até os grandes conglomerados formados com controle acionário ou participação de capital externo. É nessa relativa convivênciacom "divisão de funções", concorrência, recriação — de diversas formas de capital, apesar do rápido processo de oligopolização em termos gerais, que se situa o capital das cooperativas agrícolas mais desenvolvidas empresarialmente. Sua participação ou não nos diversos subsetores decorre das próprias condições técnicas, econômicas e políticas da formação do subsetor.

A produção de insumos, que teve uma rápida expansão em virtude da tecnificação da agricultura, exemplifica a diversidade no tocante ao grau de concentração do capital, à participação de capital externo e à divisão do trabalho entre os vários segmentos do capital. Nesse sentido, a produção de máquinas agrícolas passou de 8.372 unidades em 1950 para $156.592 \mathrm{em}$ 1970, a quase-totalidade no Sudeste e Sul. ${ }^{51}$ A produção de tratores, por ser resultante da diversificação da indústria de automotores e já se ter implantado no Brasil sob o controle das corporações de capital transnacional ainda no período do desenvolvimentismo populista e devido ao seu patamar técnico e grau de concentração de capital, é um dos subsetores em que a participação do capital externo é proporcionalmente maior. Existe uma estreita correlação entre o grau de concentração de capital, a tecnologia envolvida e o controle pelo capital externo desse ramo industrial. ${ }^{52}$ Das empresas produtoras de tratores no Brasil, a Massey Ferguson (capital inglês-norte-americano), a Valmet (finlandês) e a Ford (norte-americano) controlam cerca de $80 \%$ do mercado nacional. O restante é basicamente ocupado pela CBT - Companhia Brasileira de Tratores (controle acionário do capital nacional), Caterpillar do Brasil (norteamericano), Case do Brasil (idem), Komatsu Brasil (japonês) e Agrale (controle acionário do capital nacional). ${ }^{53}$ Por sua vez, diversamente da

${ }^{51}$ No Rio Grande do Sul o número de tratores evoluiu de 34.334 em 1967 para 49.384 em 1973 , além de a produção agrícola ser regionalizada e, portanto, concentrar o aumento de seu uso em regiões determinadas. Nas regiões de produção de trigo e soja existe uma média de 60ha/trator e em algumas regiões do Noroeste do Estado, essa razão era de 33 e 47ha/trator. Vide BRDE - Banco Regional de Desenvolvimento do Extremo-Sul. A indústria de máquinas agrícolas no Rio Grande do Sul. Porto Alegre, 1975, pp.3-16.

52 "Por exemplo, um levantamento recente mostra que as empresas multinacionais são responsáveis por aproximadamente $60 \%$ das vendas, lucros e ativo das 500 maiores firmas privadas do Brasil. (...) As empresas multinacionais controlam, pelo menos, 70\% das receitas das vendas nas indústrias de veículos de transporte, equipamento elétrico, produtos farmacêuticos, mecânica, plásticos, borracha e cigarros." Brandt, William K. et al., "Estratégias mercadológicas de empresas multinacionais no Brasil", in Revista de Administração de Empresas. Rio, 16 (4), julho-agosto de 1976, p.7.

${ }^{53}$ Ver Conjuntura Econômica. Rio, 26 (1), janeiro de 1972, pp.50 e 52 e "Quem é quem na economia brasileira", in Visão, 55 (5), 27 de agosto de 1979, p.222. 
produção de tratores, a produção de implementos agrícolas em geral apresenta uma menor concentração e conta com menor participação do capital externo. Assim, enquanto a produção de tratores está quase exclusivamente sob controle do capital externo e, em termos especiais, centralizada em São Paulo, a produção de implementos agrícolas, quando não está a cargo de subsidiárias das próprias fábricas de tratores, é formada em sua maior parte por médias e, conforme o caso, inclusive por pequenas empresas de capital nacional, com origens artesanais. Em 1965, o Rio Grande do Sul produzia $24 \%$ do total de implementos e máquinas agrícolas do total fabricado no Brasil e 50\% dos implementos; em 1970, essa participação era de um terço da produção nacional, contra 68,9\% e 83,4\%, respectivamente, para São Paulo. De qualquer modo, das 55 empresas pesquisadas em 1975, havia duas com mais de $60 \%$ de capital estrangeiro, enquanto outras tinham participação estrangeira minoritária. Esse ramo industrial foi o que mais se expandiu no Rio Grande do Sul nas últimas décadas, como decorrência do processo de tecnificação da produção agrícola. $^{54}$

A produção de colheitadeiras automotrizes, a exemplo da produção de tratores, teve um rápido crescimento e internacionalização do capital produtor, suprindo boa parte do mercado, anteriormente dependente apenas da importação. Ainda que algumas empresas tenham começado e se desenvolvido com capital privado nacional (Indústria de Máquinas Agrícolas Ideal, Schneider \& Logman), praticamente a totalidade das empresas produtoras já possui associação num maior ou menor grau com capital externo, em alguns casos associando capital privado nacional, externo e estatal. Do mesmo modo que na indústria de fertilizantes e outras,

\footnotetext{
${ }^{54}$ BRDE, op. cit., pp.1-11. A menor participação do capital estrangeiro na produção de implementos agrícolas, além das razões apontadas, pode decorrer também do fato de que, apesar de o ramo ser o mais concentrado do setor metal-mecânico no Rio Grande do Sul, conforme o estudo citado, a origem da maior parte dessas indústrias é de bases artesanais e somente tomou impulso nas últimas décadas, com o incremento da produção de trigo, soja e arroz. Esses três produtos representam $80 \%$ do estoque de tratores e máquinas agrícolas no Rio Grande do Sul e praticamente a totalidade de seu cultivo utiliza fertilizantes, tração mecânica integral, aproximando-se em muito dos países de agricultura mais mecanizada.
}

na produção de colheitadeiras o capital externo participa minoritariamente, tendo em vista o acesso ao crédito oficial subsidiado e outros incentivos. ${ }^{55}$

Em relação aos defensivos agrícolas, a hegemonia do capital externo é praticamente total, responsabilizando-se por cerca de $80-90 \%$ da sua produção. Em 1975 foi aprovado pelo Governo federal o Programa Nacional de Defensivos Agrícolas, visando incentivar a produção nacional a suprir a demanda interna de defensivos. Segundo esse Programa, a contribuição nacional crescia de $22 \%$ em 1974 para quase $50 \%$ em 1980, e dele participariam tanto o capital externo, quanto o privado nacional e o estata1. ${ }^{56}$ Das 24 principais empresas vinculadas à produção de produtos químicos para a agricultura em 1979, havia cerca de 20 com controle acionário estrangeiro (11 norte-americanas, três alemãs, duas suíças, duas japonesas), uma com controle acionário estatal e cerca de três com controle acionário do capital privado nacional.

O consumo de fertilizantes teve um dos maiores crescimentos entre todos os insumos agrícolas nas últimas décadas, sendo que, entre 1965 e 1974, o consumo aparente no Brasil aumentou em 581\%. Durante esse período as regiões Norte e Nordeste mantiveram sua participação estagnada em cerca de $8 / 10 \%$ do consumo nacional, o Leste e o Centro-Oeste, conjuntamente, diminuíram sua participação relativa de $77 \%$ para $62 \%$, enquanto a participação do Sul (Rio Grande do Sul e Santa Catarina), em boa medida como resultado do incremento da produção de trigo e soja,

\footnotetext{
55 É o caso, por exemplo, da Indústria de Máquinas Agrícolas Ideal, situada no Rio Grande do Sul. Essa empresa teve seu controle acionário adquirido pelo Banco lochpe de Investimentos, ficando o capital majoritário (60\%) com esse banco (privado nacional) e $40 \%$ com o BRDE (oficial), através de uma empresa holding formada pelo capital dos bancos acima (52\% do capital da empresa) e $32 \%$ do capital que pertencia até essa data à Fahar (multinacional alemã) e que passou para a International Harvester (norte-americana). O capital da empresa ficou sob controle acionário nacional e foi acrescido em $400 \%$. Ver ZeroHora, Porto Alegre, 19 de março de 1978, p.27 e Coojornal, Porto Alegre, abril de 1976

${ }_{56}^{\text {p. }}$ Esse plano, em alguns casos, resultou na implantação do "tripé" em sua forma mais pura, talvez em boa medida pelo controle tecnológico exercido pelo capital externo. Por exemplo, “(...) com capital inicial de 150 milhões de cruzeiros a CNDA foi concebida dentro de um modelo tríplice (1/3 - capital privado nacional, 1/3 - grupo estrangeiro e 1/3 - estatal), para a pesquisa, síntese de matérias ativas, formação e comercialização de defensivos agrícolas (Lavoura Arrozeira. Porto Alegre, 31 (310), novembro-dezembro de 1979, p.47.
} 
elevou-se de $13 \%$ para $30 \%$ do consumo, no período. ${ }^{57}$ Em 1978 , o Rio Grande do Sul, isoladamente, já representava $32 \%$ do consumo nacional de fertilizantes, importando $100 \%$ da matéria-prima. ${ }^{58}$

A participação da indústria localizada no Brasil na produção de fertilizantes é mínima e, embora tivesse aumentado de $7,6 \%$ para $34 \%$ do consumo total na década de 1950 , teve um decréscimo a partir de 1965 , atingindo apenas $19 \%$ do consumo em 1970. Por outro lado, a produção de matérias-primas nacionais era bem menor, atingindo apenas $10 \%$ do consumo dessa época e $8 \%$ em $1974,{ }^{59}$ o que provocou a formação do plano de incentivo à expansão da produção desse insumo básico por parte do Estado brasileiro, inclusive com inversão direta na produção. Ao implantar o PNFCA - Programa Nacional de Fertilizantes e Calcário Agrícola, em 1974-75, o Governo brasileiro pretendia obter a autossuficiência no tocante a adubos e expansão da produção de calcário até $1981 .^{60}$ É evidente que, para esse plano de incentivos, se contaria tanto com capital estatal como privado nacional e externo. Em 1978, dos 3,1 milhões de toneladas consumidos, mais de 1,7 milhão de toneladas foi importado e 1,3 milhão de toneladas foi produzido internamente, chegando-se perto da autossuficiência em algumas matérias-primas como a rocha fosfática, ainda que outras, como o potássio, continuem sendo totalmente importadas. ${ }^{61}$

Em virtude de a produção de fertilizantes no Brasil consistir quase exclusivamente na mistura da matéria-prima, exigindo assim um patamar técnico e de concentração de capital relativamente pouco elevado, da estratégia de incentivos do Estado brasileiro à produção desse insumo e das políticas de acesso a esses incentivos, a produção de fertilizantes conta tanto com empresas de capital privado nacional como com empresas de capital externo e estatal. Em muitos casos, na mesma empresa estão representadas as três formas de capital.

Em 1979, o setor de indústria química e farmacêutica, no qual se inclui a produção de fertilizantes, contava com 422 empresas, das quais 286

\footnotetext{
${ }^{57}$ Conforme Dirigente Rural. São Paulo, 14 (516), maio/junho de 1975.

${ }_{58}$ Jornal do Comércio. Porto Alegre, 25 de maio de 1978, p.34.

${ }^{59}$ M.S., Suplan. Produção e abastecimento; perspectivas e proposições: síntese 1975-76. Brasília, 1975, p.63.

${ }^{60}$ Dirigente rural, op. cit., loc. cit.

${ }^{61}$ Quem é quem na economia brasileira', in Visão, 27 de agosto de 1979, p.253.
}

com controle acionário privado nacional, 26 estatais e 110 estrangeiras. Especificamente no setor de química, das 219 empresas, 142 eram privadas nacionais, com 35,3\% do patrimônio líquido, 56 estrangeiras, com 31,3\% do patrimônio líquido - o que confirma a regra segundo a qual as empresas, com controle acionário do capital externo ou estatal possuem um maior grau de concentração - e 26 com controle acionário estatal, com $33,4 \%$ do patrimônio líquido do ramo. ${ }^{62}$

No Rio Grande do Sul, das quatro empresas que representavam a quase-totalidade da produção de fertilizantes em 1979, havia três com controle acionário do capital privado nacional e uma (Companhia Riograndense de Nitrogenados) com controle acionário do Estado do Rio Grande do Sul, com participação ainda da Petrobrás (30\%) e Fibase (40\%), dos quais $10 \%$ são de empresas de capital privado. ${ }^{63}$ Outra empresa, a CRA (Companhia Rio-grandense de Adubos) que até o final de 1978 pertencia à Wintershall (subsidiária da multinacional alemã BASF) passou seu controle acionário ao grupo de capital majoritário nacional Olvebra — uma das maiores empresas exportadoras e processadoras de soja do Estado e atuando como conglomerado em outros ramos industriais; a participação do Grupo Reno (franco-germânico) nessa empresa ficou em 29,3\%. A razão básica da nacionalização do controle acionário, a exemplo de outros setores, são as dificuldades de participação nos incentivos estatais. ${ }^{64}$

O que importa reter desses exemplos empíricos é que, apesar das fricções entre as diversas formas de capital, sua associação, não apenas na formação do padrão de acumulação em geral, mas na formação das próprias unidades produtivas, demonstra que a lógica de sua reprodução supera essas divergências; em outras palavras, a subordinação do capital privado nacional ao capital externo e/ou estatal é decorrente de sua fraqueza enquanto capital e não de algum plano diabólico por parte do capital estrangeiro ou da falta de incentivos estatais, ainda que estes estejam condicionados pelas forças sociais em jogo, entre as quais o capital externo. Nesse processo cada forma de capital participa com suas condições e estratégias específicas: o Estado visando a reprodução e coordenação da acumulação investindo naqueles setores estratégicos e de retorno mais a

${ }^{62}$ Visão, op. cit., p. 255

${ }^{63}$ Jornal do Comércio. Porto Alegre, 15 de maio de 1978, p.34.

${ }^{64}$ Zero Hora. Porto Alegre, 22 de novembro de 1978, p.25. 
longo prazo; capital externo ocupando as faixas que requerem a participação do capital mais desenvolvido e por isso com mais tecnologia e poder de barganha; o capital nacional associando-se a uma ou outra forma de capital, ou preenchendo espaços específicos nos quais possui poder de concorrência.

De qualquer modo, pelo menos nos períodos de crescimento econômico acelerado, o próprio crescimento do capital estatal e externo "abre espaços" para o capital privado nacional, o que, por razões óbvias, não elimina a concorrência entre forças desiguais, assentadas em patamares tecnológicos e produtivos diferenciados e nas vicissitudes das alianças e conflitos entre as várias formas de capital. Essa concorrência entre forças desiguais torna-se mais acirrada nas conjunturas de crise, como é o período pós-1975. Nesse sentido, a concorrência entre capitais de diversas magnitudes tende a um processo de associações, fusões e seleção, onde o capital externo "penetra de cima para baixo", ao passo que o capital privado nacional se integra horizontalmente, adquire capacidade de concorrência por força da acumulação ou dos incentivos estatais, ou se associa.

Entretanto, isso não é suficiente para que o capital das cooperativas de produtores agrícolas - que tiveram um rápido crescimento nas últimas décadas - , passasse a controlar algum ramo importante da produção de insumos agrícolas. As maiores exceções à regra restringem-se às fábricas de defensivos agrícolas e calcário da Fecotrigo, que, apesar da relativa expansão recente, está longe de ameaçar algum concorrente. Para a expansão dessa produção, as cooperativas contam com um mercado de certa forma cativo formado por seus associados, o que não elimina ele forma alguma a concorrência oligopólica. A forma básica de enfrentar os concorrentes no que tange à tecnologia foi importar "pacotes tecnológicos". Outras cooperativas produzem insumos agrícolas como subprodutos da industrialização da soja, por exemplo. No entanto, além de se destinarem quase que totalmente à exportação, tais insumos, quando colocados no mercado interno, via de regra são comercializados com empresas que controlam esses setores.

O controle da produção de insumos agrícolas em geral pelo grande capital externo e/ou estatal, com um alto grau de oligopolização, é um dos responsáveis básicos pela estrita dependência e entrelaçamento efetivo entre as cooperativas mais desenvolvidas empresarialmente e a agroindústria em geral, visto que a produção agrícola em que se apoiam essas cooperativas conta com uma altíssima participação dos insumos modernos na composição dos custos da produção agrícola. Assim, por exemplo, na produção de trigo e soja - como de maneira geral ainda que distinta, na agricultura produtivamente mais moderna — de acordo como os cálculos para o estabelecimento dos preços mínimos, o item máquinas e implementos situa-se entre $20-30 \%$ do total dos custos da produção; o item insumos modernos (fertilizantes, calcários, sementes, defensivos) nunca fica abaixo de $40 \%$, atingindo em alguns casos mais da metade dos custos, ao passo que as despesas com mão-de-obra se situam entre $6 \%$ e $10 \%$ e o arrendamento entre $5 \%$ e $10 \% .^{65}$

\subsubsection{Comercialização e processamento da produção agrícola}

Procuraremos demonstrar a seguir a participação das diversas formas de capital na comercialização e processamento da produção agrícola. Aqui também tentaremos detectar o grau de concentração e a nacionalidade do capital nas diversas fases da comercialização e processamento e o tipo de participação das cooperativas agrícolas.

No Rio Grande do Sul e demais Estados do Sul, a indústria de processamento de produtos primários tem um peso relativamente grande na formação do parque industrial em geral; naquele Estado, conforme dados do Censo Industrial de 1970 , esse ramo representava $60 \%$ da produção e do emprego industrial. Desse setor, somente a indústria de alimentação representava $25,9 \%$ dos estabelecimentos, $19 \%$ do pessoal ocupado, 31,2\% do valor da produção e 16,1\% dos salários dos estabelecimentos com mais de cinco pessoas ocupadas. ${ }^{66}$ Além disso, há uma política agressiva de incentivos a esses ramos industriais.

Na comercialização e processamento da produção agrícola em geral e de trigo e soja em especial, atuam cooperativas agrícolas, grandes e pequenas empresas de capital nacional, de capital externo, estatal ou misto,

${ }^{65}$ Conforme dados da Fecotrigo. Encarte da revista Agricultura \& Cooperativismo. Porto ${ }^{65}$ Conforme dados da Fecotrigo. En
Alegre, (10), fevereiro de 1977, p.25.

${ }^{66}$ Rio Grande do Sul. Informe geral sobre a agroindústria gaúcha. Porto Alegre, 1976, Quadro I. Ver também Relatório da Gazeta Mercantil. São Paulo, 27 de abril de 1976, pp.7- 
de forma diferenciada e com lugar determinado no movimento geral da realização dos produtos agrícolas. A participação desses diversos agentes e forças socioeconômicas distingue-se não só pela magnitude mas também pela qualidade dessa participação.

Por outro lado, na comercialização e, em alguns casos como a soja, também no processamento da produção, é onde a expansão da atuação das cooperativas agrícolas é considerável. Assim, na última década, com algumas oscilações para cada ano, cerca de $90-95 \%$ do trigo; $60-80 \%$ da soja; $80-85 \%$ da lã; $20-30 \%$ do feijão e $25-30 \%$ da uva no Rio Grande do Sul foram comercializados a partir do produtor por cooperativas ${ }^{67}$ Contudo, essa participação, de maneira geral, restringe-se às primeiras fases da comercialização, salvo aqueles casos em que essa participação chega ao processamento e/ou exportação da produção, como a soja, por exemplo, exportada em média $60-70 \%$ por cooperativas, no Rio Grande do Sul. Desse modo, com exceção daquelas cooperativas que chegaram a formar grupos econômicos com razoável poder de barganha, essa hegemonia refere-se apenas à primeira fase da comercialização, isto é, a aquisição diretamente do produtor, para posteriormente repassar à indústria e/ou comércio atacadista.

Por exemplo, na safra de 1966-67, as cooperativas foram responsáveis por $86,1 \%$ da comercialização do trigo e $53,7 \%$ da soja diretamente do produtor, no Rio Grande do Sul. Os demais agentes compradores de trigo, diretamente do produtor, na época, foram o comércio $(9,3 \%)$, órgãos governamentais $(2,4 \%)$ e a indústria $(0,4 \%)$. Entretanto, se tomada a participação das várias instituições compradoras no total das transações comerciais de trigo e soja, independentemente da origem da compra, ou seja, incluindo tanto a compra diretamente do produtor quanto aquisições de outros vendedores, a participação das cooperativas declina de modo drástico. Sua participação na comercialização do trigo diminui para

67 Dados extraídos de M.A., Suplan, Pesquisa socioeconômica das cooperativas de produtores e da produção agrícola brasileira. Brasília, 1977, v. 1, e Dirigente Rural. São Paulo, maio de 1980, p.8. "Sob a Administração das cooperativas agrícolas construíram-se ao redor de $25 \%$ de toda a capacidade de armazenamento do país; perto de $40 \%$ da capacidade de esmagamento de soja e exportaram-se $8 \%$ a $10 \%$ do total de excedentes agrícolas, $40 \%$ da carne do Rio Grande do Sul e quase $80 \%$ da lã; $90 \%$ do trigo e perto de $70 \%$ da soja; mais de $70 \%$ da produção de leite, atingindo $10 \%$ da população e $16 \%$ dos imóveis rurais." Conforme Dirigente Rural, supracitado, p. 8 .
$28,98 \%$ do total, enquanto as indústrias foram responsáveis por 70,91\% e os atacadistas por $0,11 \%$ das aquisições em geral. No caso da soja, além das cooperativas que adquiriram $53,7 \%$ do total diretamente do produtor, nessa safra os comerciantes adquiriram $37,7 \%$ e as indústrias $3,5 \%$ do total diretamente do produtor. Portanto, também para a soja, na aquisição diretamente do produtor, as cooperativas foram responsáveis pela comercialização da maior parte. Porém, a exemplo da comercialização do trigo, na aquisição da soja em geral, independentemente da origem da aquisição, as cooperativas são responsáveis por apenas $24,97 \%$ das transações comerciais, contra $16,17 \%$ para os atacadistas e $58,86 \%$ para a indústria. ${ }^{68}$

Evidentemente essa participação dos diversos agentes compradores deve ter-se alterado na última década no caso da soja — o trigo é de compra estatal predominantemente através das cooperativas -, alterações essas provocadas pelo aumento da capacidade de processamento e exportação de algumas cooperativas, o que não elimina sua concorrência mais acirrada com o grande capital na compra do produto e na industrialização, e sua integração efetiva com esse capital em termos de funcionamento entrelaçado, subordinado e conjunto, por exigências do próprio padrão de acumulação, o que o apoio estatal não elimina, mas consolida.

Ou seja, ainda que a comercialização e a exportação através de cooperativas tenha se expandido, por força dos incentivos à exportação e de sua expansão enquanto empresas, na exportação de soja em especia $1{ }^{69}$ a hegemonia continua sendo das empresas multinacionais, que operam em forma de conglomerados, atuando em diversos setores simultaneamente, o que aumenta seu poder de barganha pela maior concentração e maior capacidade de captação de recursos financeiros externos e pela flexibilidade do capital. ${ }^{70}$ Mesmo assim, a expansão e integração horizontal e vertical de

${ }^{68}$ Dados extraídos de Rio Grande do Sul, "Programa de Investimentos Integrados para o Setor Primário", in Estudo Global da Comercialização. Porto Alegre, 1975, v. 1, Tabelas 64 e 65 .

${ }^{69}$ Em 1978, em torno de 120 cooperativas atuaram no comércio externo, metade delas com sede no Rio Grande do Sul.

"Também no comércio internacional as empresas estrangeiras são beneficiadas por suas redes de comercialização, já existentes. (...) na amostra das (5.113) maiores empresas, 51,4\% da exportação é realizada pelas estrangeiras e apenas 9,8\% pelas empresas privadas brasileiras", sendo o restante estatais. Rattner, Henrique, "Aspectos econômicos e 
grupos econômicos cooperativos e os incentivos e mesmo a participação do capital estatal diretamente (COBEC) criam condições para sua participação na comercialização para além dos portos de embarque; para tanto se associa e se integra, jurídica ou funcionalmente, capital de cooperativas com privado nacional, estatal-privado nacional e nacional com estrangeiro, ${ }^{71}$ num processo contraditório de fricções, concorrência e interdependência entre os diversos agentes. Contudo, é essa mesma interdependência que faz com que, por exemplo, o Estado apoie os grupos econômicos de cooperativas para a implementação de suas políticas específicas de incentivos à produção e exportação e estes busquem nessas mesmas políticas uma maior barganha frente ao capital externo.

A comercialização e processamento da soja é um dos ramos onde as cooperativas agrícolas mais penetraram, ${ }^{72}$ como decorrência de uma série de fatores, entre os quais se destacam a expansão da produção dessa oleaginosa e a sua complementaridade (pelo menos em relação ao Sul) à

tecnológicos da indústria de alimentos brasileira", in Revista de Administração de Empresas. São Paulo, 18 (3), julho setembro de 1978, p.22. Quanto à oligopolização, internacionalização e estratégias do grande capital que atua no setor de oleaginosas, ver em especial o excelente trabalho de Muller, Geraldo, Estratégias das corporações multinacionais na indústria oleaginosa brasileira (mimeog.). São Paulo, Cebrap, 1978.

${ }^{71}$ A nova legislação cooperativista de 1971 (Lei $n^{\circ}$ 5.764) favoreceu esse processo ao permitir a associação de cooperativas com outras empresas de capital privado. Por exemplo, a Cotrijuí exporta através da Cotriexport, na qual possui controle acionário, sendo o restante capital privado; o que acontece com a Fecotrigo, que exporta da mesma forma ou através da Cobec (Trading cujo controle acionário é privado, com $30 \%$ do Banco do Brasil e participação de outros bancos oficiais). Além da Cobec, no ramo de produtos agrícolas em 1975, havia mais de uma dezena de exportadoras Trading companies formadas pelo Governo brasileiro visando o incentivo às exportações, das quais uma com controle acionário estrangeiro e as demais com capital privado nacional, ou misto com capital estatal. Ver Rio Grande do Sul, Assembleia Legislativa, $1^{\circ}$ Simpósio Nacional da Soja, op. cit., p.100 e passim.

72 Das 20 maiores empresas brasileiras (da edição especial da revista Exame de 1979) por receita operacional vinculadas à produção agropecuária em 1979, cerca de seis eram cooperativas de trigo e soja e, das maiores empresas do Rio Grande do Sul nesse ano, por receita operacional ou por vendas, havia apenas uma cooperativa, a Cotrijuí, que se expandiu basicamente através da comercialização e industrialização de soja e trigo. Segundo a pesquisa do M.A., Suplan, já citada em 1975, a soja, bovinos, leite e uva foram responsáveis por $70 \%$ do valor das vendas dos produtos industrializados pelas cooperativas, época em que o Rio Grande do Sul detinha 65\% do valor dos produtos industrializados pelas cooperativas e a soja representava $26,6 \%$ desse total. produção tritícola, no que tange aos aspectos produtivos e aos incentivos governamentais, sendo que as atuais cooperativas envolvidas na comercialização e processamento da soja foram criadas tendo-se em vista a comercialização do trigo; além disso, paralelamente à expansão da produção de soja, que se destina à exportação, o parque industrial para seu processamento ainda não havia sido implantado, isto é, ainda que existissem no Rio Grande do Sul pequenas empresas que operavam com outras oleaginosas (linhaça, girassol etc.), não havia ainda um parque industrial razoável dedicado a esse ramo industrial, com exceção da Samrig. Como a expansão da produção da soja ocorreu paralelamente e inclusive foi um dos responsáveis pela capitalização e expansão empresarial das cooperativas, estas passaram a investir nesse espaço econômico alargado pela expansão da produção e exportação da soja. Soma-se a isso que à política de exportação interessa remeter ao exterior mercadorias com certo grau de beneficiamento, ou seja, com um valor real ativo maior, o que contribui para que as cooperativas tenham maior acesso aos financiamentos. Além disso, a própria substituição da banha e outros óleos com um custo maior pelo consumo do óleo de soja contribui para o barateamento de um componente básico da alimentação urbana.

Esses elementos que atuam no sentido da rápida expansão da industrialização da soja, que teve seu apogeu numa fase de crescimento econômico acelerado, favoreceram a convivência de uma grande heterogeneidade de empresas tanto em relação ao tamanho quanto ao patamar técnico. No entanto, o aumento da concorrência, a concentração do capital e os novos patamares técnicos tendem a substituir essa convivência pela seleção através de falências ou fusões.

Com efeito, a indústria de processamento de soja no Brasil em geral é muito mais concentrada que no Rio Grande do Sul. Contudo existe um processo de rápida concentração e bipolarização nesse Estado, sendo um dos polos compostos pelas grandes indústrias de capital externo, com sua participação ou com controle acionário do capital privado nacional (Olvebra) e grandes cooperativas e, de outro lado, as pequenas empresas de capital privado nacional, sem condições de acompanhar o processo.

Já no período 1969-74 esse processo de concentração estava em plena marcha e se aprofundou nos anos posteriores. Assim, em 1974, das 36 empresas de processamento de soja, apenas 14 possuíam instalações de 
refino e, destas últimas, apenas duas possuíam capacidade de esmagamento acima de 1.000t/ano, sendo que nenhuma das restantes ultrapassava 300t/ano e já nessa época cerca de " $86,8 \%$ das empresas do Paraná, 94,5\% das do Rio Grande do Sul e 97,1\% das de São Paulo estariam sendo antieconômicas". ${ }^{73}$ No período posterior a 1974, a concentração se intensificou, ainda que muitas empresas que apenas extraíam óleo bruto ingressassem na produção de óleo refinado, entre elas algumas cooperativas.

Desse modo, as cinco unidades consideradas grandes possuíam 63,4\% da capacidade de extração em 1974 e passaram a deter 73,5\% em 1977; essas mesmas unidades possuíam 73,9\% da capacidade de refino em 1974 e passaram a deter $87,2 \%$ em 1976 e $73,6 \%$ em 1977, sendo que a interrupção do processo de concentração referente à capacidade de refino em 1977 é decorrente da "desativação de duas unidades pertencentes a uma grande empresa a qual concentrou o setor de refino numa terceira instalação" e da expansão da capacidade de refino de pequenas e médias empresas. As 14 empresas consideradas pequenas eram responsáveis por $10 \%$ da extração e 6,5\% do refino em 1974 e passaram a extrair 6,7\% e refinar 7,8\% da soja no Rio Grande do Sul em 1977. Nesse ano havia 38 unidades produzindo óleo degomado e industrial e farelo-torta, 13 óleo refinado, 4 sabão de soja, três farinha e apenas uma (Samrig) produzindo gordura hidrogenada. margarina, proteína e glicerina e uma (Olvebra) produzindo leite de soja, evidenciando assim a estrutura diferenciada entre as diversas empresas. ${ }^{74}$

Em 1979 (março-dezembro) houve sete cooperativas que participaram da industrialização da soja no Rio Grande do Sul, as quais foram responsáveis por cerca de $16,84 \%$ do tota $1 .{ }^{75} \mathrm{O}$ restante $(83,16 \%)$

\footnotetext{
${ }^{73}$ M.A., Suplan, Produção e abastecimento; perspectivas e proposições; 197576. Brasília, Suplan, 1975, p.67; Codesul-BRDE, A indústria de óleos vegetais no Rio Grande do Sul. Porto Alegre, 1969, pp.20-44 e Rio Grande do Sul. Ass. Legislativa, op. cit., p.234.

${ }^{74}$ BRDE, A indústria de óleo de soja no Rio Grande do Sul. Porto Alegre, 1979, pp.47 e 7172. O Rio Grande do Sul foi responsável por 49,1\% da industrialização da soja em 1974 e por $37,9 \%$ em 1977.

${ }^{75}$ Destacando-se a Cotrijuí com 39,52\% e a Fecotrigo com 39,84\% do total industrializado por cooperativas. A Fecotrigo, com a inauguração de sua nova e grande unidade em Cachoeira do Sul, passou a possuir uma capacidade instalada de esmagamento de cerca de $3.800 t / a n o$ e a Cotrijuí conta com cerca de 1.200t/ ano.
}

ficou a cargo da Samrig (Grupo Bunge y Bom) com 13,28\%, Olvebra (controle acionário do capital privado nacional) com 21,49\%; Incobrasa, $5,7 \%$, A Perin (Copatrade, Suíça) com $2,59 \%$ e a Anderson Clayton com $2,32 \%$, sendo o restante $37,78 \%$ divididos entre as 24 empresas restantes. ${ }^{76}$ Desse modo, o controle da indústria de processamento de soja é exercido, de um lado, pelo grande capital nacional, formado basicamente pela Olvebra, Cotrijuí e Fecotrigo, o que não significa que essas cooperativas tenham controle do setor, enfrentando concorrência inclusive ao nível da aquisição da matéria-prima; de outro lado, está o grande capital externo ou a ele associado, carro-chefe do processo de expansão desse ramo industrial, secundados todos por uma miríade de pequenas empresas de capital privado nacional.

É importante ressaltar que, a exemplo desse ramo industrial no Brasil, ${ }^{77}$ no Rio Grande do Sul também se apresenta um alto grau de

\footnotetext{
${ }^{76}$ Conforme dados do Sindicato da Indústria de Óleos Vegetais.

${ }^{77}$ Uma das preocupações básicas das cooperativas em 1979 foi ter baixado sua participação no recebimento da soja diretamente do produtor para cerca de $50 \%$, isto é, perder terreno nesse campo para os demais grupos compradores. Para se ter uma ideia da concentração do capital no ramo de óleos vegetais a nível nacional, a exemplo da indústria alimentícia, em 1976, a Samrig, a Olvebra e as Indústrias Coelho detinham 40\% do patrimônio líquido do ramo, no qual as dez maiores representavam cerca de 60\%. Revista de Administração de Empresas, op. cit., p.32. No Rio Grande do Sul, o Grupo Olvebra, em via de se tornar conglomerado, é responsável em média por $25,25 \%$ da industrialização da soja $(11,25 \% \mathrm{em}$ relação ao Brasil) e planeja expandir-se para o Estado do Espírito Santo. (Jornal do Comércio. Porto Alegre, 19 de fevereiro de 1978, p.1 e 22 de julho de 1978, p.5.) Atualmente essa empresa conta com uma capacidade de esmagamento de cerca de 1 milhão e 800 mil t/ano em três unidades, o que, juntamente com as 600 mil t/ano da Samrig, representa $60 \%$ da capacidade instalada no Estado no final de 1977. Acrescente-se ainda que tanto a Olvebra quanto a Samrig atuam em diversos ramos e setores industriais e comerciais, ou seja, em forma de conglomerados. Informações e dados de Gazeta Mercantil; balanço financeiro, São Paulo, 1980, p.11; Zero Hora. Porto Alegre, 12 de agosto de 1980 e BRDE, financeiro, São Pau cit., Tabela 38.
Ep.

É importante notar ainda que a Samrig e a Olvebra, ao lado do Estado e Cooperativas, foi quem impulsionou e incentivou a produção de soja no Rio Grande do Sul, sendo que um dos marcos da modernização da produção de soja foi a “(...) instalação, em 1958, em Porto Alegre, da Sociedade Anônima Moinhos Rio-grandense (Samrig), do Grupo Bunge y Bom. Segundo seu diretor gaúcho, Arnaldo Coelho Borges, a Samrig distribui hoje mais de $8 \mathrm{mi}$ sacos de sementes de soja para 6,5 mil agricultores e aumentou sua capacidade de esmagamento de 120 mil toneladas, em 1958 para 600 mil toneladas, em 1976." (Negócios em Exame, 12 de abril de 1978, p.76.)
} 
concentração, marchando para a oligopolização. Já surgem alguns conglomerados, com a participação tanto do capital externo quanto do capital nacional, como exemplificam a Olvebra e as cooperativas empresarialmente mais desenvolvidas.

O acelerado crescimento da indústria de transformação de soja pode ter criado condições para a manutenção das pequenas e médias empresas de capital nacional ou de cooperativas. Entretanto, sua expansão depende da manutenção desses requisitos, e pela conservação da divisão de funções entre as grandes e pequenas empresas. Isso é pouco verossímil, na nova fase da economia, com um novo patamar tecnológico para o setor, atingido apenas pelas maiores empresas do capital privado nacional, do capital externo ou das cooperativas. Estas, em especial as socioeconomicamente melhor situadas, tratam de ingressar nessa nova fase através de uma política agressiva de integração vertical e de seu ingresso num padrão tecnológico mais elevado. Para as cooperativas em especial, isso é condicionado também de forma mais direta por sua posição frente ao mercado de matérias-primas, que no caso da soja, está longe de ser oligopsônico, e pelo apoio financeiro oficial direto.

Por sua vez, o processo de realização da produção tritícola, ainda que conte praticamente com os mesmos elementos da soja, é bem mais simples, por uma série de razões. Acontece que, ao se desenvolver a produção tritícola nacional, no final da década de 1950, ao contrário dos grupos econômicos cooperativos, já estava em processo de consolidação a grande indústria moageira, surgida sob controle acionário externo e com características oligopólicas, em torno da qual girava uma constelação de pequenos "moinhos coloniais" com um peso decrescente e praticamente nulo em termos de participação efetiva.

Por outro lado, basicamente como efeito de o trigo consumido internamente ter sido sempre em boa parte importado, a intervenção do Estado nessa esfera também foi sempre mais direta. Nessa intervenção na comercialização foram enquadradas as cooperativas, o que foi facilitado por ser uma produção voltada apenas para o suprimento interno e, por isso, com uma indústria de transformação com menor expansão, ${ }^{78}$ envolvendo assim um menor grupo de agentes e interesses.

Em 1962, por reivindicação das cooperativas, que ia também ao encontro dos interesses do Estado em sistematizar e controlar a política de incentivos à produção e evitar desvios dos subsídios, a produção tritícola passou a ser adquirida exclusivamente pelo Banco do Brasil, que criou para a efetivação das transações o Departamento Geral de Comercialização do Trigo Nacional da CTRIN. ${ }^{79}$ Esse órgão é responsável também pela distribuição do trigo nacional e importado aos moinhos. O recebimento do produto, bem como o seu armazenamento e distribuição são feitos pelas organizações autorizadas pela CTRIN, destacando-se a Fecotrigo e demais cooperativas filiadas — responsáveis em média por $80-90 \%$ — e entidades paraestatais, como a Cibrazen e Ceasa e, com participação desprezível, organizações particulares como os "moinhos coloniais" e clandestinos, que fogem do controle governamental.

As cooperativas apenas coletam e revendem o trigo, com cotas fixadas pela CTRIN, recebendo pela coleta, armazenamento etc. uma taxa de serviços. O preço pago aos produtores é baseado nos cálculos dos custos da produção elaborados pela Fecotrigo e depois "negociados" com órgãos estatais. As cotas de consumo industrial para os moinhos e a fixação da quantidade a ser importada é responsabilidade da Sunab Superintendência Nacional de Abastecimento. Dessa forma, a indústria de processamento adquire o trigo, via de regra, dos órgãos governamentais. As cooperativas tritícolas foram criadas e fortalecidas para se tornarem agentes de comercialização da produção interna entre os produtores e os órgãos

\footnotetext{
${ }^{78}$ No período 1965-73 o consumo total de trigo no Brasil aumentou de 2,1 milhões para 3,8 milhões de toneladas e a produção passou de 190 mil em 1965 para 1,5 milhão de toneladas em 1973, isto é, de 10\% para 50\% do consumo. (Conjuntura Econômica. Rio, 28 (4), abril de 1974, pp.78-79.) Por outro lado, no caso da soja no Rio Grande do Sul, somente no período 1970-75 as exportações de produtos agropecuários aumentou em 3,2 vezes enquanto os produtos de origem vegetal, dos quais a soja e seus derivados (farelo torta) representam $82 \%$, aumentaram em 5,8 vezes entre 1966 e 1975, significando uma taxa anual de 50\% no período. (Jornal do Comércio. Porto Alegre, 8 de maio de 1978, p.8.)

${ }_{79}$ Ver M.A., Suplan, Produção e abastecimento; perspectivas e proposições; trigo $1975-76$. Brasília, 1975, p.39. A CTRIN (Comissão de Compra do Trigo Nacional), criada em 1962 foi transformada em 1967 em Departamento Nacional e integrada à Diretoria de Coordenação e Execução da Política de Crédito Rural, responsável pela política em relação ao trigo. 
governamentais que se encarregam da distribuição à indústria de processamento.

É nessa esfera que se localiza o grande capital, preponderantemente transnacional. Se na industrialização da soja as pequenas e médias empresas de capital nacional e de cooperativas participam em determinado grau do processo ainda que conjuntamente e em desigualdade de condições em relação à capacidade produtiva e poder de barganha, no caso da industrialização do trigo essa configuração é bem mais dicotômica. A hegemonia nesse ramo no Rio Grande do Sul desde a década de 1950 é da Samrig, do Grupo Bunge y Born. ${ }^{80}$ Para se ter uma ideia do poder de oligopólio desse conglomerado, cumpre mencionar que no Brasil ele atua, por exemplo, no setor de moinhos, mineração, têxtil, fertilizantes, óleos vegetais, aviação, química, turismo, cigarros, seguros etc. Ela age através de suas três grandes ramificações, entrelaçadas acionariamente, representadas pela Sambra, Moinho Fluminense e Moinho Santista, sendo que a maior parte das empresas em que participa é sem controle acionário a fim de conseguir, entre outras vantagens, acesso aos subsídios oficiais. A Sambra é o maior complexo agroindustrial e exportador do Brasil, com um volume de vendas em 1979 de cerca de 20 bilhões de cruzeiros e exportação de 300 milhões de dólares, representando 2,5\% da receita cambial brasileira. A Moinho Fluminense é responsável pela moagem de $500 \mathrm{mil}$ toneladas de trigo no Rio de Janeiro, sendo a Samrig sua mais importante associada.

A hegemonia desse grupo manifesta-se claramente também no sentido do entrelaçamento do grande capital com os órgãos do Estado. Por

\footnotetext{
${ }^{80}$ A exemplo do que ocorre com as empresas produtoras de fertilizantes, defensivos, colheitadeiras etc., esse grupo também "nacionalizou" em 1979 uma de suas principais empresas, a S.A. Moinho Santista Indústrias Gerais, da qual detinha 51,78\% do capital passando para $48 \%$. As razões são basicamente as mesmas, isto é, em “(...) primeiro lugar, as ações da companhia, que já possuem razoável índice de liquidez na bolsa paulista, ganham negociabilidade maior, pois têm acesso às carteiras dos investidores institucionais. (...) Outra vantagem proporcionada pela condição de empresa de capital privado nacional (embora os acionistas estrangeiros, do Grupo Bunge y Bom, argentino, mantenham o poder de decisão) à Moinho Santista é que a empresa está credenciada a desfrutar de regalias oficiais e mesmo de recursos de agências governamentais, como BNDE, Caixa Econômica Federal, Banco do Brasil etc." (Ver Bunge y Born, "Vantagens da nacionalização", in Gazeta Mercantil. São Paulo, 2 (3), maio de 1980, p.10.)
}

exemplo, suas subsidiárias controlam praticamente todas as entidades representativas ou sindicatos patronais do setor no Brasil. Um dos instrumentos para tanto são as presidências dessas organizações que, via de regra, estão vinculadas a empresas do grupo, através das quais se conseguem acesso e influência na política referente à produção, comercialização e processamento do trigo e outros produtos. No caso do Rio Grande do Sul, participa do grupo um ex-secretário do Estado trabalhando especificamente neste sentido, isto é, em suas relações com o Estado. $^{81}$

Como consequência dessa grande concentração e controle da indústria de processamento de trigo e seu aprofundamento, no Sul existe um processo de rápido extermínio dos pequenos moinhos de capital nacional ou "moinhos coloniais". Somente nos anos de 1975-77 estes foram reduzidos de cerca de 2 mil no Rio Grande do Sul, para aproximadamente 800. Os que restam é mais por questões de sobrevivência econômica da mão-de-obra familiar envolvida que propriamente por viabilidade da realização do lucro. $^{82}$

As indústrias de processamento de trigo no Rio Grande do Sul de propriedade de cooperativas, cerca de 13 , se bem que se situem num nível técnico e de capital superior a esses "moinhos coloniais", não estão ligadas ao grande capital. Seu ponto de apoio maior para sobrevivência é o mercado de certa forma cativo representado pelos associados. De qualquer maneira, a participação do trigo na venda de produtos industrializados pelas cooperativas é desprezível, situando-se em torno de 0,2\% em 1973 e 0,1\% em $1975^{83}$

\footnotetext{
${ }^{81}$ Ver Silva, Paulo Couto e, As multinacionais e o trigo: a economia do Brasil em perigo (rnimeog.). Porto Alegre, 1977, (s.n.t.), p.8.

${ }^{82}$ Esse extermínio violento provocou uma reação política por parte dos responsáveis por esses moinhos, através da qual foi conseguido certo amparo legal para sua manutenção. Ver Agricultura \& Cooperativismo. Porto Alegre, 1 (9), janeiro de 1977, pp.8-12.

${ }^{83}$ M.A., Suplan, op. cit. , v. 1.
} 


\subsection{A atuação do Poder Público e das cooperativas agrícolas}

\subsubsection{O Estado e a orientação e coordenação do processo de produção e apropriação}

Procuraremos a seguir traçar as linhas básicas do grau e formas de intervenção do Estado em sua estratégia de orientação e coordenação da reprodução do capital e do modelo de dominação social, conforme as vicissitudes da dinâmica econômico-política, para mais adiante explicitar o cooperativismo agrícola empresarialmente mais desenvolvido como sendo inscrito nessa dinâmica.

A intervenção do Estado na formação e desenvolvimento da agricultura no Sul do Brasil não se restringe à fase de modernização dessa agricultura. A própria imigração, responsável básica pela formação da atual estrutura fundiária, é, em boa parte, obra direta da intervenção oficial.

Contudo, esta intervenção, apesar de em última instância buscar o desenvolvimento do capitalismo brasileiro como um todo, é moldada pela conjugação de forças de cada momento histórico.

Com o desenvolvimento industrial, a agricultura passou a ser, basicamente, o fornecedor de matérias-primas industriais, mercado consumidor de insumos industrializados e bens de consumo, fonte de divisas para a importação de insumos industriais, provedora de alimentos para a reprodução da força de trabalho urbana e fonte do "exército de reserva" dessa força de trabalho. Por isso, mesmo que a razão última seja a viabilização da reprodução capitalista, que gradativamente passa a ter na acumulação industrial o principal centro dinâmico, a forma pela qual o desenvolvimento do capitalismo transforma a agricultura abrange não só a reprodução e acumulação do capital na agricultura, mas em especial a reprodução do sistema como um todo e o lugar que a produção agrícola ocupa nessa reprodução. Nesse sentido, o Estado assume o lugar de direcionador não só da acumulação, mas também da apropriação que cada classe ou setor de classe obtém, de acordo com a correlação de forças do momento histórico.

Se atentarmos para as condições nas quais o Estado brasileiro incentiva a produção e controla a apropriação dos excedentes entre os vários grupos e classes sociais, através do controle dos preços, subsídios, incentivos fiscais, criação de infraestrutura de produção e realização etc., não resta dúvida de que, embora isso tudo seja regido pela acumulação capitalista, essa acumulação não se dá pelas leis da oferta e procura, numa situação de livre concorrência, de forma automática, mas por "controles administrativos". 84 Além disso, a forma pela qual a indústria brasileira se desenvolve, com tecnologia sofisticada e, por isso, com necessidade de menos capital variável, faz com que a necessidade da agricultura como fornecedor de força de trabalho diminua, tornando o que antes era apenas uma necessidade para o crescimento industrial em um problema social, na medida em que cria um excedente de mão-de-obra, que em última instância tem a ver com a "responsabilidade social" do Estado.

Portanto, o crescimento do "exército industrial de reserva" se processa de forma desproporcional em relação às necessidades de força de trabalho para os setores urbanos. Ao mesmo tempo em que isso pode ter um poder bastante grande no rebaixamento dos salários, pode pressionar para que o avanço do capitalismo no campo se molde às necessidades de viabilização social e política deste capitalismo, que o Estado busca paralelamente à reprodução e acumulação do capital.

Outro aspecto fundamental é o caráter de dependência e subordinação da agricultura, à medida que esta se integra na produção industrial, tornando-a economicamente inviável sem os recursos e o apoio estatal. O apoio progressivo à agricultura no Brasil vai desde os subsídios indiretos, através da manipulação das taxas de câmbio, prática já iniciada no período colonial, aos subsídios diretos iniciados no início do século atual, provocado inicialmente pela crise da economia cafeeira (Convênio de Taubaté), até a dependência da agricultura em relação ao Estado em caráter permanente, a partir da Revolução de Trinta. ${ }^{85}$ Cada etapa histórica teve, porém, sua forma específica, conforme a imbricação Estado-sociedade e especificamente, Estado-agricultura. Mas é o período iniciado com a depressão de 1929-30, e com o novo rearranjo das forças socioeconômicas emergidas daí, que nos interessa de forma mais direta, já que é a partir

${ }^{84}$ Conforme Oliveira, Francisco de, A economia brasileira: crítica à muro dualista. São Paulo, Cebrap, 1977, p.15.

${ }^{85}$ Ver Guimarães, Alberto Passos, "Uma etapa de crescimento agrícola: da Revolução Industrial à crise geral", in Temas de Ciências Humanas, São Paulo, (2), pp.69-98, 1977. 
desse período que começam a ser gestadas no Brasil as novas políticas agrícolas, que tiveram como resultado o surto de crescimento da produção nacional de trigo e soja.

$\mathrm{Na}$ medida em que se consolida a economia industrial no Brasil e se configura o padrão de acumulação vigente, com base na grande empresa e na associação de capitais, aumenta a participação crescentemente decisiva do poder público no sentido da criação das condições propriamente econômico-produtivas e da viabilização político-ideológica dessa forma de acumulação e reprodução do capital. Por outro lado, essa participação crescente do poder público no sentido de dar viabilidade histórica ao padrão de acumulação intensifica-se, concomitantemente, na busca da inserção da produção agrícola e da "sociedade agrária", de acordo com as condições e interesses concretamente envolvidos e a estratégia geral da formação e reprodução do capitalismo associado-dependente.

Alguns autores têm enfatizado o numeroso contingente de mão-deobra, a oferta elástica de terras e a “(...) viabilização do encontro desses dois fatores pela ação do Estado construindo a infraestrutura, principalmente a rede rodoviária" para explicar a participação da agricultura na formação da economia industrial brasileira. Dessa oferta elástica de terras e mão-de-obra resultaria uma “(...) permanente expansão horizontal da ocupação com baixíssimos coeficientes de capitalização e até sem nenhuma capitalização prévia: numa palavra, opera como uma sorte de acumulação primitiva". ${ }^{86}$ Pensamos que a chamada "acumulação primitiva" ou transferência de excedentes não requer necessariamente a expropriação da propriedade formal da terra do produtor rural - como acontece com o posseiro na fronteira agrícola expulso pela grande produção capitalista, que incorpora o excedente que se forma pela posse transitória da terra. $\mathrm{O}$ produtor rural pode continuar a ser proprietário da área cultivada e mesmo dos instrumentos de trabalho em geral. Isso porque, na formação tanto dos preços mínimos oficiais quanto do preço médio real, entram em jogo agentes e forças sociais em condições extremamente diferenciadas.

${ }^{86}$ Oliveira, Francisco de, "A economia brasileira: crítica à razão dualista”, in Oliveira, F. de e Sá Jr., F., Questionando a economia brasileira. $2^{\mathrm{a}}$ ed., São Paulo, Cebrap/Brasiliense, $2^{\mathrm{a}}$ ed., 1976, pp.15-17.
Por outro lado, como tentamos demonstrar em páginas anteriores, as bases técnicas em que se dá boa parte da produção permitem que haja aumento da produtividade física do trabalho pela modernização da produção, sem que se forme necessariamente a empresa capitalista. Desse modo, tendo em vista essas condições diferenciadas, é lógico que boa parte dos produtores trabalhem em condições economicamente deficitárias do ponto de vista da remuneração do trabalho e do capital, ainda que seja uma produção técnica e produtivamente desenvolvida. Um dos pontos de apoio disso é o caráter do desenvolvimento industrial, com um padrão de produção e poder de controle na luta pela apropriação dos excedentes, com respaldo e regulamentação por parte do Estado, ${ }^{87}$ e numa espécie de "reprodução simples" e/ou negativa permanente por parte das unidades produtivas agrícolas em determinados setores da produção, o que não significa que nos demais setores da produção agrícola não haja acumulação de capital.

Se, de um lado, a intervenção do Estado na agricultura, tanto no que se refere a instrumentos mais específicos como crédito ou subsídios, quanto às políticas de caráter mais geral, evolui no sentido de seu crescimento acelerado, por força das próprias necessidades da acumulação, de outro, o apoio seletivo é o que define a intervenção oficial na agricultura. Através disso são selecionados os produtos e os produtores, isto é, as condições técnicas e sociais em que se realiza a produção e seu incremento, ao mesmo tempo em que o Estado faz a mediação política, buscando suporte nos setores abrangidos pelo apoio para a viabilização sociopolítica da reprodução do padrão de acumulação adotado, de acordo com a correlação de cada conjuntura.

O marco inicial da consolidação da assistência financeira e demais políticas dirigidas à agricultura brasileira de maneira mais sistemática pode ser considerado a criação da CREAI (Carteira de Crédito Agrícola e Industrial) do Banco do Brasil, em 1937. Em 1965, com a criação do Sistema Nacional de Crédito Rural (SNCR) pelo Governo federal, foi

87 Ou, segundo o diretor executivo da Comissão de Financiamento à Produção, Paulo R. Vianna: "Quem paga a supervalorização cambial é a agricultura. Toda a política, que através de tabelamento corta a evolução natural dos preços, impõe um tributo ao setor agrícola (...). Temos que continuar tirando dinheiro da agricultura, para subsidiar outros setores (...)." (Jornal do Comércio. Porto Alegre, 13 de abril de 1978, p.3.) 
permitido que toda a rede bancária dele participasse. A participação dos bancos particulares, visto que os juros reais para a agricultura são negativos — inferiores à taxa de inflação -, tem por base a Resolução $\mathrm{n}^{\circ} 69$, segundo a qual os bancos particulares devem aplicar $10 \%$ de seus depósitos no crédito agrícola ou recolhê-los ao Banco Central, recebendo um juro de 7\%. Outra forma de aumentar o montante de recursos para o crédito agrícola foi a criação do Fundo Nacional de Refinanciamento Rural (FNRR) para receber os recursos dos bancos privados e de outras fontes como financiamentos externos e usá-los no financiamento agrícola. ${ }^{88}$

No que tange especificamente aos subsídios ao uso de insumos modernos, merece destaque a Funfertil (Fundo de Estímulo Financeiro ao Uso de Fertilizantes e Suplementos Minerais) criada para pagar a totalidade dos juros (17\%) nos empréstimos para aquisição de fertilizantes. Em 1969, com a substituição da Funfertil pela Fundag (Fundo Especial de Desenvolvimento Agrícola) o Governo federal passou a subsidiar a aquisição de outros insumos, como ração, defensivos etc., pagando $8 \%$ dos juros e ficando os restantes $7 \%$ a cargo do produtor.

O crédito agrícola, que representava $18 \%$ do crédito total do Brasil em 1960 e passou a representar 30\% em 1968, teve um crescimento enorme nas últimas décadas. ${ }^{89}$ Assim, de 1969, quando contava com 9,3 bilhões de cruzeiros, para 1971, teve um crescimento em valor real de $33,6 \%$ e em 1978 os recursos destinados a esse tipo de crédito já representavam um aumento de quatro a cinco vezes em relação a 1973, em valor real, equivalendo a mais do dobro do crescimento da produção agrícola. ${ }^{90}$ Desse modo, no período 1973-78, o crédito rural cresceu em valor real em $190 \%$, enquanto a produção agrícola aumentou em $17 \%$ e o preço da terra no Brasil em cerca de $1.780 \%$. No final do período, 1978, a política de crédito agrícola movimentou cerca de 300 milhões de cruzeiros, ou seja, mais de 80\% do Produto Agrícola Nacional, enquanto em 1960 representava apenas $10 \%$. "Como se trata de recursos emprestados a juros bem inferiores aos de mercado, há uma carga de subsídio que, segundo a Fundação Getúlio Vargas, representa $20 \%$ do Produto Agrícola. Além disso, o setor rural

\footnotetext{
${ }^{88}$ Paiva, Ruy M. et al., O setor agrícola no Brasil, op. cit., pp.123-24.

${ }_{90}^{89}$ Dados extraídos de Paiva, R.M. et al, op. cit., p.130.

90 Jornal do Comércio. Porto Alegre, 25 de setembro de 1978, p.6. O Banco do Brasil destinou em 1977 cerca de 55\% de seu crédito à agricultura, todo subsidiado.
}

conta com subsídios fiscais que, somados aos créditos, alcançaram 170 bilhões de cruzeiros em 1978, quase 50\% da receita do Tesouro Nacional" de $1977 .{ }^{91}$ Para o presidente do Banco do Brasil, em 1973, para cada cruzeiro de recursos próprios, o produtor agrícola brasileiro contava com 60 centavos de crédito e em 1978, para cada cruzeiro próprio, o crédito entrava em Cr\$ 8,60. Ainda que o crédito não represente o conjunto de incentivos e subsídios - existem ainda, por exemplo, os incentivos fiscais, a criação de infraestrutura etc. ${ }^{92}$ - esse enorme crescimento do financiamento pode ser tomado como o indicador básico da relação entre o apoio oficial e a produção agrícola.

Quanto à seletividade e orientação em relação a produtos agrícolas específicos, em 1976, por exemplo, a soja, o trigo, o café e o arroz, que representavam $49,6 \%$ da produção agrícola brasileira, receberam $80 \%$ do crédito rural; o feijão recebeu $0,4 \%$ e o milho, que representava $16,1 \%$ da produção, recebeu 5,9\% dos financiamentos do Banco do Brasil ${ }^{93}$. No Rio Grande do Sul, de acordo com os dados do Banco Central, em 1978, apenas três produtos - soja, trigo e arroz — receberam $90 \%$ do crédito de custeio e somente a soja recebeu $46 \%$, acontecendo coisa semelhante com os financiamentos para crédito destinado à garantia de preços mínimos e à comercialização. ${ }^{94}$ Para cada um desses produtos, em especial para o trigo, o apoio oficial é parte integrante de sua história. Para o trigo, o número de empréstimos mais que triplicou entre 1964 e 1970, enquanto o valor deflacionado procura aumentar em mais de cinco vezes no período para o Rio Grande do Sul. ${ }^{95}$

\footnotetext{
${ }^{91}$ Negócios em Exame. São Paulo, (180), 18 de julho de 1979, p.77.

${ }^{92}$ A série de obras realizadas em 1972-73, com a participação do Ministério da Fazenda, Ministério dos Transportes, Banco Interamericano de Desenvolvimento e a Federação Nacional de Compras das Associações Cooperativas do Japão, estariam orçadas em 500 milhões de dólares. Esse plano de obras denominado "Corredores de Exportação", consiste na organização de uma infraestrutura de transportes e armazenamento, do qual faz parte o Porto de Rio Grande, por onde é exportada a soja gaúcha. (Revista Ipiranga. Rio Grande, 13 (60), 1972, pp.20-25.)

${ }_{93}^{93}$ Agricultura \& Cooperativismo. Porto Alegre, 2 (24), abril de 1978, p.7.

${ }^{94}$ Ver $O$ Interior. Carazinho, 28 de outubro de 1978, p.5, e FEE, Indicadores Econômicos RS. Porto Alegre, 4 (1/2), janeiro-julho de 1976, p.109.
}

${ }^{95}$ Paiva, R.M. et al., op. cit., p.174. 
A seletividade dos financiamentos e subsídios quanto aos produtos torna-se evidente quando, por exemplo, o Sistema Nacional de Crédito Rural - incluindo todos os bancos privados e oficiais - atinge apenas de $10 \%$ a $20 \%$ dos produtores agrícolas. "Segundo levantamentos do Banco do Brasil, $80 \%$ dos produtores brasileiros trabalham sem crédito governamental. Entre os $20 \%$ que o usam, entretanto, a distribuição é muito desigual. Em 1976, ano da última estatística disponível no BB, enquanto $83 \%$ dos contratos receberam $18 \%$ dos recursos totais do crédito agrícola, apenas $1 \%$ dos contratos absorvia 39\%". ${ }^{96}$ Ainda segundo dados do Banco do Brasil, dos recursos destinados à agricultura, os "grandes produtores" absorviam 20\% em 1966 e aumentaram sua participação para 54\% em 1976, enquanto os "médios" decresceram sua participação de $46 \%$ para $35 \%$ e os "pequenos", de $34 \%$ para $11 \%$ nos recursos no período. O mesmo acontece com os recursos destinados ao financiamento da agropecuária no Rio Grande do Sul, onde existiam aproximadamente 500 mil estabelecimentos agrícolas e apenas cerca de 15 mil recebiam financiamentos nesse ano e apenas 3,08\% dos produtores receberam $41,34 \%$ do valor dos empréstimos do Banco do Brasil e, se incluídos todos os bancos que financiam a agricultura, $3 \%$ dos empréstimos equivalem a $50 \%$ do crédito. ${ }^{97}$ Muitas vezes, essa participação, compulsoriamente retida, chega até a ultrapassar o capital próprio de que as regionais dispõem para si. De outro lado, as cooperativas regionais precisam da organização centralizada das centrais, no que diz respeito ao transporte e à comercialização de sua produção. Dependem, pois, das centrais, através de vários mecanismos financeiros, econômicos e organizacionais.

\footnotetext{
${ }_{97}^{96}$ Negócios em Exame, op. cit., p.79.
}

${ }^{97}$ O Interior. Carazinho, 23 de março de 1978. Existem indícios de que -como decorrência da nova correlação de forças na medida em que o latifúndio perde poder em relação às facções da burguesia industrial-financeira envolvida no complexo agroindustrial e às restrições ao crédito provocadas pela crise econômico-financeira e política a partir de 1975 a tendência se reverteria no sentido de aumento do crédito agrícola a pequenos produtores. Entretanto, nesse caso mudariam os critérios, direcionando uma maior parte àqueles pequenos e médios produtores em condições de participarem do processo de modernização e integração da produção agrícola, mas não a seletividade do apoio do Estado, cuja lógica é a reprodução do capital e a mediação política. Sobre as mudanças na política agrícola a partir da nova situação de classes e correlação de forças, ver Sorj, Bernardo, "Estrutura agrária e dinâmica política no Brasil atual”, in Revista de Cultura \& Política. São Paulo, 1 (1), agosto de 1979, pp.19-25.
Dentro desse quadro, não é de estranhar que o cooperativismo leiteiro apresente um dos principais problemas do sistema associativo brasileiro em geral, o problema da não-participação e da não-identificação dos cooperados. Para eles, a cooperativa pode chegar a se assimilar a qualquer empresa comercializadora de leite: a palavra "cooperativa", tal como é usada por muitos produtores, serve para indicar a empresa a que entregam suas matérias-primas, seja uma associação de produtores, seja uma empresa privada de capital nacional ou estrangeiro. Acontece frequentemente ouvirse falar de empresas privadas de laticínios como de "cooperativas". E, de fato, não pode existir muita diferença, aos olhos dos produtores, entre os dois tipos de empresas: as duas têm o mesmo comportamento, oferecem as mesmas vantagens etc. $\mathrm{Na}$ área leiteira, especialmente, é difícil falar de retorno financeiro aos cooperados, por causa da baixa rentabilidade do produto.

A necessidade de se adaptar às exigências de um mercado liderado por corporações de capital altamente concentrado e a consequente escolha, pelas cooperativas centrais, de um esquema fortemente empresarial, entra em choque com a difusão da ideologia cooperativista entre seus associados: se o fortalecimento do sistema de cooperativas se faz por sua transformação em empresas capitalistas cada vez mais concentradas, isso dificultará, necessariamente, a identificação do produtor com sua cooperativa e sua consequente participação associativa.

É dentro desse contexto econômico-produtivo e político, com base na seletividade/exclusão, que se inscreve o cooperativismo agrícola empresarialmente desenvolvido, enquanto agente, entre outras coisas, de implementação e reprodução desse processo.

\subsection{O cooperativismo como agente de viabilização econômico- política do capitalismo associado-dependente}

Nesta parte tratamos de inserir e explicitar o cooperativismo agrícola na dinâmica do quadro mais geral delineado até aqui, isto é, no processo de formação de classes sociais na agricultura stricto sensu, a integração da produção agrícola ao capitalismo industrial-urbano em especial à agroindústria e à atuação do Estado brasileiro. Para tanto, após esboçarmos as linhas gerais do cooperativismo agrícola no Brasil, tomamos o 
cooperativismo empresarialmente mais dinâmico, em especial de trigo e soja, como ponto de referência empírica básica.

O cooperativismo agrícola pode ser apreendido, de um lado, pela racionalização econômico-produtiva que essa forma de organização exerce em contextos determinados; de outro lado, pelo caráter de mediação sociopolítica que assume no processo social, tendo em vista a viabilização e a reprodução da expansão do capitalismo, em condições determinadas. Concretamente, esses dois aspectos básicos atuam entrelaçadamente e é a explicitação dessa busca da racionalidade socioeconômica e da mediação política através do cooperativismo que examinamos a seguir.

Num contexto histórico como o que está em questão, o cooperativismo agrícola assume o caráter de uma das formas através das quais o Estado e suas bases sociais atuam no sentido de, concomitantemente, desenvolver as forças produtivas e manter as tensões e conflitos sociais nos limites do politicamente viável para o padrão de acumulação e dominação pública. Nesse sentido, essa forma de organização adquire o caráter de instrumento de compatibilização e catalisação das tensões sociais.

Concordamos quando se afirma que, na "América Latina os movimentos cooperativistas têm sido geralmente estimulados por motivos políticos: são como um meio para pacificar um povo rebelde. Buscam suavizar os efeitos adversos de uma depressão, promover ou ao menos prometer uma vida em áreas atrasadas instáveis e alimentar apetites de clientela política". ${ }^{98}$ Entretanto, na medida em que o cooperativismo tende a se consolidar como um dos agentes básicos da orientação, organização e integração da produção agrícola e, portanto, da reorganização da estrutura produtiva, como tende a ser o cooperativismo empresarialmente mais desenvolvido no Sul do país, essa forma de associativismo continua sendo um movimento político, mas assume também o caráter de instrumento de viabilização econômico-produtivo do processo. Aliás, na medida em que o cooperativismo envolve a estrutura produtiva de maneira mais profunda, redimensiona assume mais efetivamente seu caráter político, que no caso em questão é representado também pela viabilização da aliança de classes e

${ }^{98}$ Borda, Orlando Fals, El reformismo por dentro en América Latina. $3^{\text {a }}$ ed., México, Siglo Veintiuno, 1976, p.15. demais agentes envolvidos no ciclo produtivo. Soma-se a isso - no caso em questão é bom frisar - o contexto político brasileiro em que surgiu e se expandiu essa forma de cooperativismo, ou seja, o final do período populista onde se gestavam algumas das condições do Estado autoritário e o período de sua consolidação.

Por estar inserido na dinâmica do processo social, o cooperativismo agrícola, como qualquer tipo de cooperativismo, amolda-se às transformações e contradições desse processo, de acordo com as condições socioeconômicas e políticas que servem de base a esse tipo de associação, ao mesmo tempo em que essas bases sociais podem ser influenciadas pelo mesmo.

\subsubsection{Configuração geral do cooperativismo agrícola no Brasil}

De maneira geral, o cooperativismo agrícola no Brasil pode ser alinhado nos grandes moldes em que se dá o desenvolvimento da agricultura brasileira. Desse modo, numa primeira caracterização encontramos as cooperativas ligadas aos produtos tradicionais de exportação (açúcar no Nordeste, café em São Paulo) que se caracteriza por ser altamente comercial, formado, em termos de quadro social, basicamente por grandes proprietários rurais que nas últimas décadas de certa forma tendeu ao enfraquecimento, visto que seus sócios conseguem com certa facilidade acesso direto aos incentivos oficiais e à política de exportação. $\mathrm{O}$ segundo grande tipo de cooperativismo agrícola no Brasil surge vinculado à modernização e integração da agricultura e geograficamente situa-se no Centro-Sul, tendo emergido basicamente a partir de grupos de colonos (japoneses em São Paulo e italianos alemães no Sul). A composição social dessas cooperativas é altamente heterogênea no que se refere ao tamanho das unidades produtivas dos associados e à estrutura destas, se bem que os associados, em sua grande maioria, podem ser considerados "minifundiários" e "neocamponeses". Ao mesmo tempo em que essas cooperativas se caracterizam por estarem voltadas para a comercialização, a realização da produção se dá tanto no mercado interno (por exemplo, trigo no Sul e hortigranjeiros em São Paulo) quanto no exterior (soja). ${ }^{9}$

${ }^{99}$ Ver Mato, Manoel Andrés, "A Cooperativa agrícola na dinâmica social”, in Cadernos do CEAS. Salvador, (33), pp.19-37, setembro-outubro de 1974. Além desses dois grandes tipos, 
Para exemplificar a composição dos associados em cooperativas basicamente por aquilo que designamos na primeira parte do trabalho por "neocamponeses", pesquisa realizada com dados de 1975 demonstrou que a proporção de associados em cooperativas agrícolas que não utilizam trabalho assalariado em seus estabelecimentos é de $86,1 \%$ no Sul, contra $75,3 \%$ no Nordeste e 22,0\% no Sudeste. Apenas 0,5\% dos associados de todas as cooperativas nos três Estados do Sul utilizam mais de dez assalariados em seus estabelecimentos, enquanto que no Nordeste esta porcentagem é de $3,2 \%$ e no Sudeste é de $17,5 \%$. Ainda que, pela própria seletividade das cooperativas, os produtores associados tenham estabelecimentos com área superior à média, a maior parte deles explora estabelecimentos considerados pequenos e médios.

A despeito das reservas com que o sistema cooperativista seria visto por setores da burocracia estatal, foi elaborado a partir de 1976 pelos órgãos do Estado o $1^{\circ}$ Pronacoop ( $1^{\circ}$ Programa Nacional de Cooperativismo), tendo como objetivos básicos o aumento do número de associados em cooperativas de 1 milhão e 300 mil para 2 milhões e 600 mil no período de 1976-79 e estimular e "racionalizar"o cooperativismo, em especial na agricultura. Esse projeto triplicaria as verbas governamentais para esse fim, sendo implantado por órgãos governamentais (Incra, Embrater e BNcC), ${ }^{100}$ fazendo parte da estratégia de modernização e aumento da produtividade física da agricultura brasileira.

"De acordo com o Departamento de Desenvolvimento Rural do Instituto Nacional de Colonização e Reforma Agrária (Incra), em meados do ano passado (1979) 2.460 cooperativas (de diferentes graus) estavam

existem outras formas de experiências cooperativas no meio rural brasileiro, embora quantitativamente pouco significativas e, por não estarem diretamente ligadas à modernização e integração da agricultura, não nos interessam aqui.

${ }^{100}$ Ver Planejamento e Desenvolvimento. Rio, 4 (41), outubro de 1976, pp.62-3. Conforme a pesquisa do M.A., Suplan, citada anteriormente, de 1973 a 1975 o número de associados em cooperativas aumentou em $27 \%$, enquanto a população brasileira cresceu em menos de $10 \%$, ainda que essas cooperativas restrinjam suas atividades quase que exclusivamente à comercialização. Em 1975, apenas 18\% das cooperativas brasileiras industrializavam parte da produção recebida. Na região Sul, essa proporção se eleva para $23,4 \%$ e no Sudeste para $21,7 \%$. Quanto à comercialização, o Sul representava nessa época $70,1 \%$ do total nacional, sendo que a soja, o trigo, o leite e o café representavam $78,8 \%$ dos produtos coletados. Os serviços de consumo das cooperativas brasileiras aumentou em 126\% nos anos de 1973 e 1974, comprando 46,5\% das mercadorias dos atacadistas e 40\% da indústria. autorizadas a funcionar no Brasil, representando este total quase o dobro do número de organizações existentes em 1974". ${ }^{101}$ Essas organizações eram responsáveis pela coleta da maior parte de uma série de produtos agrícolas - trigo-soja, leite etc. - e pela exportação de parte dessa coleta e especificamente no Rio Grande do Sul detinham 45,9\% e no Paraná 30,2\% da capacidade estática de armazenamento.

\subsubsection{Integração da agricultura e transformação do cooperativismo agrícola}

A transformação do cooperativismo agrícola de acordo com as mudanças das condições socioeconômicas da sociedade agrária onde se situa e das condições mais gerais evidencia-se na evolução do cooperativismo agrícola no Rio Grande do Sul. Nesse Estado tem-se como marco inicial do cooperativismo o ano de 1902, quando foi fundada a primeira "Caixa Econômica e de Empréstimos" (sistema Raiffeisen) em uma colônia de imigrantes, tendo como objetivo básico a ajuda financeira mútua.

A partir daí foi-se desenvolvendo nas colônias de imigrantes um cooperativismo ligado a uma agricultura formada por pequenos produtores. Nesse contexto, a associação em cooperativas tinha um caráter de defesa da remuneração do trabalho familiar frente ao comércio e à indústria de transformações. Ao mesmo tempo em que essas cooperativas se restringiam à comercialização dos excedentes agrícolas, sua dependência em relação ao Estado era mínima, visto que a agricultura camponesa das colônias nessa fase possuía um grau maior de autonomia em relação à agroindústria e às políticas oficiais.

Em 1953, por exemplo, existiam no Rio Grande do Sul cerca de 440 cooperativas de diversos tipos, com um total de 137.244 associados. ${ }^{102} \mathrm{Em}$ 1957, marco inicial do surgimento de um novo padrão de cooperativismo rural, foram recenseadas nesse estado 565 cooperativas agrícolas, que, com o progressivo desaparecimento da agricultura "tradicional" e sua integração em novas bases, se dissolveram ou foram incorporadas pelas novas.

${ }^{101}$ Dirigente Rural, op.cit., p.8.

${ }^{102}$ Ver Intercâmbio. Rio, 2 (1), janeiro de 1954, p.8. 
No caso das cooperativas de trigo - que mais tarde se transformaram em cooperativas de trigo e soja e ponta de lança de um novo modelo de cooperativismo - a época de seu surgimento é justamente o período em que os grandes produtores de trigo, atraídos pelos incentivos governamentais, consolidavam sua posição e, através delas, passavam a reivindicar melhores condições de produção e comercialização. Com o surgimento do Plano de Expansão Econômica da Triticultura Nacional (1957) e a Comissão de Organização de Cooperativas de Produtores, resultou que somente no ano de 1957 foram fundadas mais de 20 cooperativas tritícolas, além da Fecotrigo (Federação das Cooperativas Brasileiras de Trigo), todas compostas a princípio exclusivamente por grandes produtores. Com sua consolidação, o crescimento da economia da soja e a diversificação de sua atuação foram sendo facilitados e inclusive se estimulou $\mathrm{o}$ ingresso de pequenos produtores nessas cooperativas. Posteriormente foram criados mecanismos de entrada de certa forma compulsória, como o repasse de financiamentos através das cooperativas, além da própria estrutura de produção, comercialização, formação de preços, que induz os demais produtores que não os "grandes" a entrarem nas cooperativas por si sós. ${ }^{103}$

A dimensão política dessa forma de cooperativismo faz parte de sua própria gênese e, portanto, não é algo adquirido somente através de seu crescimento e centralização. Como foi exposto, foram criadas a partir de uma política governamental favorável à modernização e ao aumento da produção tritícola no final da década de 1950, durante o período caracterizado pelo populismo desenvolvimentista. Para racionalizar e controlar a comercialização, a política governamental induziu inicialmente os grandes e, mais tarde, os pequenos produtores a se associarem em cooperativas.

\footnotetext{
${ }^{103}$ A formação e desenvolvimento da Cotrijuí (Cooperativa Tritícola Serrana Ltda.) em 1957, no Noroeste gaúcho, exemplifica nitidamente o exposto. Essa cooperativa atualmente a maior cooperativa singular brasileira — foi fundada inicialmente por 16 "granjeiros" (grandes produtores), a Cooperativa Mista Mauá Ltda. e a Cooperativa Mista dos Agropecuaristas. No final de 1957, essa cooperativa contava com 60 sócios, número que passou para $11.361 \mathrm{em} 1976$ e cerca de $18.500 \mathrm{em}$ 1979. Esses associados se compunham, em termos de estrutura fundiária em 1976, em 79\% de "pequenos produtores" (com área até 50ha), 14\% de "médios produtores" (com área de 51 a 150ha) e 7\% de "grandes produtores" (mais de 150ha).
}

Acontece que, num primeiro plano, havia nesse contexto forte insatisfação e mobilização política dos produtores de trigo frente à insegurança para a comercialização da produção, controlada pela grande indústria de transformação, além das fraudes que os incentivos governamentais possibilitavam e a falta de infraestrutura de produção, armazenamento, transporte etc. Por outro lado, existia por parte do Estado o interesse de reorientar a produção e a comercialização, não apenas visando os interesses dos triticultores, mas também reduzir as importações e racionalizar e regulamentar a produção, processamento, distribuição e consumo.

Num segundo nível, já no final da década de 1950 e início dos anos 1960 , havia outros movimentos populares-reformistas, liderados por setores da Igreja, pela Frente Agrária Gaúcha e por partidos políticos. ${ }^{104} \mathrm{O}$ cooperativismo, respaldado no novo contexto, conseguiu cooptar e utilizar esses movimentos, canalizando-os conforme seus objetivos, determinados pela aliança das classes rurais melhor situadas socioeconomicamente, o Estado e o complexo agroindustrial. Foram sobretudo esses movimentos que forneceram a base ideológica para a mobilização dos produtores no sentido do cooperativismo e de determinado tipo de sindicalismo rural. Eles também organizaram e se encarregaram do trabalho de divulgação e doutrinação, primeiro pela própria dinâmica do movimento e, depois, através da criação dos departamentos de "comunicação e educação" das cooperativas. Em alguns casos, como a Cotrijuí, inclusive através da organização de núcleos de base. ${ }^{105}$

${ }^{104}$ Sobre a cooptação do Movimento Comunitário de Base, sindicalismo etc., em especial pela Cotrijuí, ver Steffens, Octávio, A comunicação e educação cooperativas (mimeog.). ljuí, 1978, pp.10 e passim. Para um relato histórico do movimento pelo cooperativismo e sindicalismo rural e trabalho de extensão em especial no Noroeste gaúcho, ver Marques, Mário O. e Brum, Argemiro J., Uma comunidade em busca de seu caminho. Porto Alegre, Sulina, 1970. Sobre as relações entre imigração, Igreja e associativismo rural em geral e cooperativismo em particular, no Rio Grande do Sul, com um tratamento apologético, ver Schneider, José O., Instituições religiosas e cooperativismo rural no Rio Grande do Sul. São Leopoldo, Unisinos, 1978. Sobre a manutenção do poder formal de uma cooperativa tritícola pela burguesia agrária e pelo campesinato melhor situado economicamente, ver Monteiro, Silvio T., Estudo de classes sociais numa cooperativa rural - Erexim. Erexim-Fapes, 1978. ${ }^{105}$ É interessante notar que, entre os planos do Governo brasileiro em relação à agricultura, existe um plano elaborado pelo Ministério da Agricultura e pelo Incra, no sentido' de instituir a "empresa social agrária", inspirado em parte na experiência da Cotrijuí. A 
Assim, essa forma de cooperativismo ocupa um determinado espaço político nesse contexto. Concomitantemente, essas organizações ampliam o espaço socioeconômico e mesmo geográfico de sua atuação. Com a evolução da agricultura "colonial" particularmente a partir do final da década de 1950 orienta-se e recria-se o cooperativismo rural. Nesse novo contexto social as cooperativas deixam de ser organizações de certa forma isoladas geograficamente - passando a expandir sua área de ação através de integração horizontal para outros municípios e também para outros Estados, como Mato Grosso - geralmente de tamanho pequeno e tendo como razão de ser basicamente a defesa dos preços dos produtos comercializáveis. O espaço socioeconômico onde passam a atuar não se restringe mais à agricultura stricto sensu, mas passam a ser o elo de ligação entre a indústria que envolve a agricultura, o Estado intervencionista e o corpo de associados, em alguns casos, avançando também, se bem que não preponderantemente, em termos de investimentos produtivos na própria transformação da produção agrícola, integrando assim a agroindústria também nesse aspecto.

Desse modo, com a crescente integração da produção agrícola, que vai progressivamente se mecanizando, os insumos modernos passam a representar um peso paulatinamente maior nos custos da produção. As cooperativas puseram-se a intervir também na comercialização de uma parte desses insumos e na difusão de novas tecnologias, além da comercialização da produção, sua atividade principal.

A preocupação do Estado de resolver os problemas de produção, comercialização, transporte, preços mínimos, armazenamento, crédito agrícola, em síntese racionalizar os incentivos à produção agrícola, vinha ao encontro dos interesses dos produtores, de unir-se em cooperativas. ${ }^{106}$ Desse

diferença maior seria que nesse plano a “(...) propriedade seria monopolizada pelas cooperativas e cada um de seus membros deteria um número de cotas condizentes com sua capacidade familiar de trabalho". (Veja, São Paulo, (153), dezembro de 1978, pp.102 e 105.) 106 "O Estado, através do orçamento público, atua na produção de bens públicos, mas ainda assim sua quantidade é limitada. As cooperativas reúnem características organizacionais que permitem complementar a função que assume o Estado.” (M.A., Suplan, op. cit., v. 1.) Por outro lado, existe certa similaridade entre a aliança agricultura-indústria-Estado, viabilizada pelo cooperativismo empresarial no Sul do Brasil e a aliança de produtores de soja nos EUA, concretizada lá, através da ASA (Associação Norte-Americana de Soja), resguardando-se as especificidades próprias, como parece ser a dependência mais estreita em relação ao Estado modo, o Estado delega às próprias cooperativas parte dos encargos, tendo em vista a solução de problemas da criação da infraestrutura de produção e realização.

Essa imbricação entre cooperativas, Estado e agroindústria, ao nível da organização da produção, reflete ao nível político uma aliança de classes que envolve de forma relativamente conduzida, controlada e mediatizada pelo Estado, as camadas sociais implicadas diretamente na produção agrícola de forma menos excludente no tocante à produção e apropriação "neocampesinato" e burguesia rural — os agentes que envolvem a produção agrícola stricto sensu e a intervenção do Estado. Se, por um lado, essa aliança encerra contradições e conflitos, latentes ou explícitos, relativamente profundos, por outro, a seletividade social desse processo e o controle e a mediação direta por parte do Estado tornam-na exequível ao ponto de não ameaçar o padrão de acumulação vigente, pelo contrário, dinamizando-o e consolidando-o. O controle e a mediação por parte do Estado abarcam toda a série de medidas no sentido de desmantelamento das demais formas de associativismo existentes no período populista. O atrelamento e controle rígido, tanto político-ideológico quanto jurídico do sindicalismo rural e sua vinculação efetiva ao assistencialismo e ao cooperativismo, ${ }^{107}$ transformando-o na única forma de associativismo com possibilidades de desenvolvimento e atuação no sentido mais político, ocupando o lugar das demais formas de atuação política, restringindo assim a política essencialmente de reivindicações que não ponham em questão o padrão de acumulação e dominação social vigente. Assim, ao transformar o

por parte do cooperativismo daqui. Sobre a aliança de produtores de soja-indústria e Governo norte-americano, ver Berlan, Jean-Pierre et al., op. cit., 1976.

107 A própria legislação sindical atua nesse sentido, na medida em que se tornou progressivamente mais corporativa e assistencialista. Com o Decreto-Lei ${ }^{\circ} 789$ de 1968 , foram divididas as categorias de trabalhadores e empregadores rurais de acordo com os módulos rurais, sendo considerado empregador quem tivesse uma propriedade superior, mesmo que não tivesse empregados. Desse modo juntaram-se diversas categorias de camponeses com a burguesia rural e latifúndios no mesmo sindicato. Com o Decreto-Lei ${ }^{\circ}$ 1.166 de 1971 se avançou ainda mais nesse sentido, ao se excluírem dos sindicatos de trabalhadores rurais os arrendatários, parceiros, posseiros, meeiros etc., que ultrapassassem em área o módulo. Mais tarde passou-se a tentar (Circular $\mathrm{n}^{\circ} 113$ ) enquadrar os filhos de camponeses maiores de 18 anos como empregados, ainda pie fizessem parte da mão-de-obra familiar. Assim, de um lado, estreitaram-se os controles e o atrelamento por parte do Estado e, de outro, transformaram-se os sindicatos em interclassistas. 
cooperativismo agrícola em principal canal político efetivo, a exemplo da politização da burocracia do Estado, restringe-se a atuação política mais direta àquelas camadas que participam na produção e apropriação de forma menos excludente. Nesse sentido, o cooperativismo passa a ser o principal catalisador das contradições e tensões sociais, mas de forma corporativa, visto que encerra, em seu quadro social, classes e camadas sociais diversas e inclusive antagônicas. Através disso, o antagonismo existente entre as classes e agentes sociais envolvidos, direta ou indiretamente, na produção agrícola é transformado em antagonismos intersetoriais. Isso se evidencia mais nitidamente nas conjunturas de crise, provocadas pelas vicissitudes naturais (secas etc.) ou pela apropriação de excedentes (preços, impostos etc.).

Por outro lado, o próprio crescimento econômico do cooperativismo e consequentemente sua maior integração às políticas estatais e ao padrão de acumulação vigente não amenizam mas acirram seus conflitos de interesses, setores da burocracia estatal, do comércio e indústria privados e com o quadro de associados, se bem que originários mais de uma luta por uma participação em melhores condições em relação aos demais agentes envolvidos, que propriamente de uma proposta de desenvolvimento que transcenda os limites da acumulação do capita $1 .{ }^{108}$ Suas lutas no sentido da mudança de políticas agrícolas específicas e na tentativa de diversificação da produção, tendo em vista suas estratégias de concorrência ou atendendo

\footnotetext{
${ }^{108}$ A não ser que se considere, como o fazem seus apologistas; o cooperativismo como a "terceira via", isto é, uma alternativa entre o capitalismo e socialismo por si só exequível, o que significa abstrair as relações sociais concretas e a lógica da acumulação e reprodução do capital. De qualquer modo, um exemplo da necessidade de organização e luta política tendo em vista seus interesses específicos pode ser a transformação recente da Fecotrigo Federação das Cooperativas Brasileiras de Trigo - na Central de Cooperativas de Produtores do Rio Grande do Sul Ltda. - Central-sul, simultaneamente com a criação da Federação das Cooperativas de Trigo e Soja do Rio Grande do Sul Ltda., que permaneceu com a mesma sigla. Para esta Federação “(...) O principal objetivo a ser buscado nesta área é participar de forma permanente na formulação da política agrícola, fazendo com que o governo ouça as reivindicações dos produtores." Agricultura \& Cooperativismo. Porto Alegre, julho de 1980, p.13. Desse modo, o cooperativismo atende uma das reivindicações de suas bases, que é a tentativa de diversificação da produção, evitando os riscos da monocultura de trigo/soja e atuando no sentido da diminuição do processo de marginalização social, na medida em que se incorporam - ou se retorna a — produções agrícolas com uma maior participação de trabalho em relação à utilização de capital/terra, ao mesmo tempo em que se busca uma participação mais ampla na formulação das políticas agrícolas.

aos reclamos do antigo campesinato em via de marginalização como consequência da rápida modernização do processo produtivo, exemplificam isso.

Paralelamente à expansão das cooperativas empresarialmente desenvolvidas e à extrapolação da sua atuação para além da agricultura stricto sensu, à sua progressiva integração às políticas do Estado e ao desenvolvimento agroindustrial, se processa a sua centralização. Visando uma maior racionalidade econômica e um maior poder de barganha frente aos concorrentes, o cooperativismo passou a defender enfaticamente uma política de integração horizontal e vertical, apresentando também a proposta de uma maior participação especificamente no complexo agroindustrial, com capitalização através de diversas formas; ou seja, a partir de uma maior participação financeira dos associados, retenção dos excedentes gerados, maior apoio financeiro do Estado etc. Todas essas propostas, em maior ou menor grau, chocam-se com os limites da acumulação baseada na agricultura com participação no processo geral de acumulação enquanto sócio-menor e com as próprias condições sóciopolíticas para sua efetivação. ${ }^{109}$

Esse crescimento e essa centralização (ou "gigantismo") tornam mais claras as divergências e mesmo a oposição de interesses específicos entre essa forma de cooperativismo e aqueles setores da indústria e do comércio que passam a sofrer concorrência mais direta. Nos últimos anos essas divergências passaram a ser explícitas e a abranger os vários escalões do Governo. Frequentemente esses setores reivindicam do Governo uma mudança na legislação cooperativa no sentido de restringir seu tamanho e as atividades desenvolvidas, a fim de evitar concorrências com o "setor privado", com as mais variadas justificativas ideológicas. A isso as cooperativas respondem a seu modo, onde os argumentos mais utilizados são a suposta eficiência econômico-social do cooperativismo como causa de seu crescimento, a contribuição do cooperativismo para a solução de problemas sociais, as vantagens que esse sistema teria para defender a economia da estatização, das multinacionais e do “(...) perigo da

${ }^{109}$ Sobre a defesa de propostas nesse sentido e sua justificativa ao nível da ideologia, ver em especial Luschner, Roque, Agroindústria como agente de modernização da empresa rural (mimeog.). Brasília, 1977. Vez também, entre outros, a Carta do Seminário de Gramado. Agricultura \& Cooperativismo. Porto Alegre, abril de 1977, p.5. 
socialização comunista" ${ }^{110}$ Evidentemente os diversos setores comerciais e industriais reagem diversamente frente à questão, visto que envolve desde concorrência fatal a alguns ramos até complementaridade e crescimento conjunto ou readaptação da estratégia no caso do grande capital, sendo a oposição maior a dos pequenos comerciantes de cereais e varejistas, estes últimos graças à concorrência representada pelos departamentos de consumo das cooperativas.

Contudo, essas oposições e divergências de interesses não impedem que determinadas cooperativas cresçam como grupos econômicos em determinados setores e linhas de produção. Entre os elementos que atuam nesse sentido destacam-se em especial o apoio do Estado, a própria expansão da produção daqueles produtos junto com os quais essas cooperativas se alicerçaram, o processo de modernização e aumento da capacidade produtiva da agricultura e a participação de cooperativas em determinadas brechas de setores da agroindústria - em termos de reinvestimentos produtivos com relativa capacidade competitiva. Essa expansão é condicionada, de um lado, pela capacidade de competição com o grande capital e, de outro, pelas alianças e conflitos dos quais resultam a política, incentivos e controles estatais. ${ }^{11}$

${ }^{110}$ Ver Informativo OCERGS. Porto Alegre, (09), dezembro de 1976 e também, entre outros, Folha da Manhã. Porto Alegre, 14 de julho de 1978, p.10.

111 "Uma vez que o cooperativismo já demonstrou suficientemente a sua eficácia como instrumento de modernização e desenvolvimento do setor agropecuário, o Governo tende a torná-lo executor dos seus programas de desenvolvimento setoriais, mediante condições especiais de obtenção de recursos e de tributação. Com isso consegue-se ampliar a ação governamental de forma efetiva $\mathrm{e}$, ao mesmo tempo, proporcionam-se às cooperativas melhores condições de competição no mercado." OCB - A Revista Nacional do Cooperativismo. Brasília, 2 (12), novembro-dezembro de 1979, p.48.

Tendo em vista a consolidação dessa expansão, que foi dinamizada pela nova legislação de 1971, ao permitir, por exemplo, a associação de cooperativas com outras empresas, uma das reivindicações básicas do cooperativismo empresarialmente desenvolvido é a formação de um banco próprio, visto que o BNCC (Banco Nacional de Crédito Cooperativo), do qual as cooperativas detêm $46 \%$ do capital e os restantes $54 \%$ pertencem ao Governo federal, não estaria em condições para tanto. Ou, segundo um de seus diretores, no “(...) estágio atual de criação, desenvolvimento e expansão de uma cooperativa está inserido o princípio da adaptação da mesma ao modelo econômico vigente, em bases empresariais nitidamente capitalistas como forma de participação num mercado altamente competitivo. Como atualmente são quase inexistentes as cooperativas de crédito e o BNCC atua discretamente numa faixa que não atende às reais necessidades do setor, o cooperativismo sobrevive, em
De qualquer modo, a participação das cooperativas mais desenvolvidas empresarialmente como sócios subordinados não impede sua expansão naquelas linhas de produção que fazem parte das estratégias da política governamental e naqueles setores que ainda não foram preenchidos pelo grande capital, de certa forma à semelhança dos grupos econômicos de capital nacional, e ampliem sua atuaçãol. ${ }^{112}$

O que esse crescimento não possibilita é que essas organizações façam frente aos oligopólios vinculados à indústria de insumos, processamento e comercialização da produção agrícola, ainda que ocupem espaços econômicos nesse sentido, ou diminuam sua dependência frente ao Estado - por mais que, ao nível da ideologia, seja esse o objetivo e razão principal de sua existência.

Com efeito, o crescimento dessa forma de cooperativismo é paralelo ao aumento de sua dependência e entrelaçamento com os oligopólios, em

termos creditícios, à base de transações com bancos particulares." OCB - A Revista Nacional do Cooperativismo. Brasília, 1 (3), maio-junho de 1978, p.37. O incentivo a determinados tipos de cooperativismo e a restrição das cooperativas de crédito ao ponto de seu quase-desaparecimento, foi uma das formas utilizadas pelo Estado para manter essas organizações financeiramente subordinadas.

${ }^{112}$ Para se ter uma ideia dessa expansão e diversificação, a Cotrijuí - uma das dez maiores empresas nacionais no setor agropecuário, ao lado da Cotrisa, Fecotrigo etc., a maior parte desse setor composto por cooperativas, segundo Negócios em Exame em sua edição especial de 1979 - e a Fecotrigo, que podem ser tomadas como modelo nesse sentido, atuam num maior ou menor grau, diretamente, através de empresas subsidiárias ou em convênio com órgãos governamentais nas seguintes atividades: comercialização da produção agrícola, repasse de crédito, assistência técnica, comercialização de bens de consumo, porto, "educação cooperativa", saúde, processamento de dados, exportações, corretora de câmbio, corretora de seguros, industrialização de soja, industrialização de leite, industrialização de carne, produção de defensivos e produtos veterinários, jornais, pesquisa e experimentação agronômica, transportes terrestre, fluvial e ferroviário, assistência social, colonização da fronteira agrícola, entre outras. Em 1979, a Fecotrigo contava com quase 200 mil associados e a Cotrijuí, isoladamente, com quase 20 mil. Por outro lado, para se ter uma ideia da "dinâmica própria" que o "fundo indivisível", que para a Cotrijuí representa cerca de $93 \%$ do capital social, toma com seu crescimento econômico, pode ser citado que em "(...) dezembro próximo a Cotrijuí abre uma loja de 5 mil metros quadrados, em ljuí, a primeira cooperativa a não atender unicamente a seus sócios. A loja venderá desde produtos de primeira necessidade (no sistema de auto-serviço) até peças para maquinaria agrícola, confecções, armarinho, insumos agrícolas e terá ainda um setor de miniatacado para pequenos armazéns. A contabilidade será separada da cooperativa, pagando-se os tributos normais de qualquer loja comercial". (Zero Hora. Porto Alegre, 6 de setembro de 1980, p.24.) 
termos comerciais e industriais, e de sua dependência financeira, políticoadministrativa e, conforme o caso, comercial em relação ao Estado. ${ }^{113}$

Por isso, a evolução econômico-política dessas organizações está estreitamente vinculada também à evolução das alianças e arranjos entre as várias facções da burguesia industrial e comercial, tanto do capital nacional quanto transnacional em relação ao Estado e da capacidade de reação dessas organizações. Aqui entra em jogo a força social e econômica que o cooperativismo representa, na medida em que representa também, de certa forma corporativamente, uma espécie de sindicato. Isso porque, por força do atrelamento e controle das demais formas de organização de classe, o cooperativismo, ainda que controlado pelo Estado a exemplo dos sindicatos, exerce efetivamente o lugar de canal político daquelas camadas que representa, cooptando inclusive as demais formas de associação.

Nesse quadro, na medida em que as cooperativas se lançam num crescimento acelerado, visando com isso um maior poder de barganha no movimento geral da acumulação - economia de escala, mercados, participação na industrialização —, um maior poder de participação nos recursos financeiros ${ }^{114}$ e melhor posicionamento político frente aos órgãos

\footnotetext{
${ }^{113}$ Por exemplo, dos dez maiores clientes da Cotrijuí, e que representavam a maior parte de seu movimento comercial no exercício de 1977-78, aparece em primeiro lugar a Cobec Inter-Corp.Paraná (empresa mista de capital estatal e privado) com cerca de $46 \%$ do valor; em segundo lugar a Cobec - Cia. Brasileira Entr. Com., com 16\%; Cotriexport Caimann, com 11\%; Cheavany Pater Elzeland Ltda. (Holanda), com 10\% e o Consejo Nacional de Subsistencia (Uruguai), com 8\%, sendo o restante distribuído entre a Sadia Concórdia, Incobrasa, Samrig, Anderson Clayton e Sipal. Conforme a pesquisa do M.A., Suplan, ${ }^{\text {op. cit }}{ }_{\text {., }}$ v. 1, no destino das vendas das cooperativas do Rio Grande do Sul, em 1975, destacam-se as vendas para as empresas privadas com $84 \%$ do total, seguidas pelas vendas para outras cooperativas com $13,6 \%$ e para o Governo, com $1,5 \%$ do total

${ }^{114}$ A Cotrijuí é um bom exemplo dessa dependência financeira. No exercício de 1969-70, essa cooperativa possuía um capital próprio de cerca de 10 milhões e 500 mil cruzeiros (cruzeiros de 1970), contra um capital total (excluindo-se o compensado) de cerca de 29 milhões e 675 cruzeiros, isto é, cerca de $35 \%$ de capital próprio. Nesse exercício o capital próprio correspondia a mais de $150 \%$ do imobilizado. Já no exercício de 1972-73, o capital próprio correspondia a 26\% do capital total de quase 113 milhões (cruzeiros de 1973). Assim, no exercício de 1969-70, a cada cruzeiro de capital próprio correspondiam cerca de 2,80 cruzeiros de capital de terceiros. Essa relação passou para mais de 1 por 3,8 em 197273, 1 por 8,1 em 1976-77 e 1 por 7,6 em 1977-78. Entre as fontes de recursos financeiros contava tanto com bancos oficiais federais, estaduais, regionais quanto particulares nacionais e estrangeiros. No exercício de 1979, devido à nova legislação que estabelece a
}

decisórios da política econômica, são levadas a aprofundar suas contradições com seu quadro social em geral. Isso fundamentalmente porque, de um lado, o maior crescimento e entrelaçamento com o Estado não suaviza essa contradição; antes a aprofunda, visto que não é resultante do movimento das cooperativas em si, mas das transformações socioeconômicas determinadas pelo avanço do capitalismo, do lugar que a agricultura ocupa na reprodução geral do capital e da diferenciação social que existe e se aprofunda no interior da própria agricultura. Por outro lado, ao mesmo tempo em que aumentam a diferenciação e exclusão social no interior da agricultura stricto sensu, amplia-se o quadro dos agentes envolvidos diretamente no processo e estreitam-se as relações entre os mesmos, tornando mais perceptível aos olhos dos próprios produtores agrícolas em geral sua vinculação com os demais agentes do ciclo produtivo, no qual eles se apresentam como o lado mais fraco.

Além disso, ao mesmo tempo em que as cooperativas são levadas a um maior entrelaçamento com o Estado e com as grandes corporações e a uma política agressiva de fusões, com exigência de sua própria dinâmica, esse crescimento e essa maior dependência financeira não lhes dão condições de dispensar, mas ao contrário aumentam suas necessidades de captação de recursos no próprio quadro social, onde existe uma reduzida parcela em condições de contribuir, em razão das condições sociais da produção agrícola.

Nesse quadro que se situa a questão da necessidade de acumulação e, de outro lado, o limite da acumulação nessas condições. É aqui que a dimensão ideológica do cooperativismo adquire sentido, na medida em que as cooperativas, pelo exposto, passam a ser progressivamente identificadas com os próprios aparelhos do Estado e/ou como um componente a mais do complexo agroindustrial, exterior, portanto ao "mundo camponês". Desse

obrigatoriedade de correção do ativo, a proporção de capital próprio aumentou para 18,97\%, isto é, ainda assim ficou abaixo de um quinto do capital total. Por outro lado, o capital socia integralizado dessa cooperativa nesse ano representava apenas 4,09\% do capital total e, se tomado todo o capital social, subscrito e integralizado, atinge apenas 7,01\% do capital total. Ao mesmo tempo, as despesas financeiras em relação às despesas totais, que representavam $14,9 \%$ do total em 1977, 22,43\% em 1978 e 26,6\% em 1979 é a sua segunda maior despesa. Entre as fontes de recursos financeiros contava tanto com bancos oficiais federais, estaduais e regionais, quanto particulares nacionais e estrangeiros. (Dados extraídos dos relatórios anuais da Cotrijuí.) 
modo, na medida em que a diferenciação e as contradições sociais se aguçam, essa forma de cooperativismo passa a exercer num grau maior sua força de desmobilização e reorientação política, especialmente através de seu "trabalho educativo". 115

Nesse sentido deve ser levada em conta a dificuldade própria de uma tomada de consciência por si só, por parte do campesinato, que ultrapasse o puramente local e imediato, a partir da diferenciação de classes no interior da agricultura, denunciando assim a aliança de classes representada nessa forma de cooperativismo e mesmo no sindicalismo rural vigente - apesar

115. Com essa expansão e centralização acelerada e a concorrência com o grande capital, o cooperativismo empresarial passou a rediscutir e são gradativamente postas em prática algumas readaptações no sentido da retomada de uma "comunicação e educação" cooperativa mais agressiva, visando em especial a maior "união" e "participação" dos associados nas cooperativas . Conjunta e interdependentemente desse aspecto, que foi relegado a um segundo plano na fase de crescimento acelerado, esse cooperativismo empresarialmente desenvolvido põe em rediscussão e atua no sentido de institucionalizar novas formas de representatividade para tomada de decisões. Nesse aspecto merece destaque a campanha de discussão sobre a "estrutura de poder" desencadeada e os ensaios postos em prática pela Cotrijuí, centrados na proposta de substituir a prática de assembleia geral de todos os associados por representantes ou delegados escolhidos nos núcleos. Essa discussão mais tarde se ampliou, em especial pela iniciativa da Fecotrigo, e já existem indícios de que o Incra pretende regulamentar e generalizar a experiência.

As justificativas básicas são a inviabilidade técnica da realização de assembleias gerais representativas, em virtude do número demasiadamente grande de associados e de sua dispersão geográfica, a necessidade de uma nova sistemática de tomada de decisões requerida pelo cunho empresarial das cooperativas e a necessidade de enfrentar a concorrência com as empresas não-cooperativas. Nesse sentido, conforme o presidente da Fecotrigo no “(...) ano passado (1979), quando o Rio Grande foi abalado por uma grande frustração da safra de soja, as cooperativas tremeram nas bases e entraram em violento processo de descapitalização. Por quê? Ora, com a quebra da colheita, a disputa pelo grão levou muitos associados a 'desviarem' o produto e as cooperativas acabaram recebendo menos da metade da produção".

"Foi por aí, aliás, que o sistema cooperativista gaúcho iniciou um longo período de reflexão. Que vantagens as outras empresas oferecem que o cooperativismo não pode oferecer?" Como forma para enfrentar essa concorrência são preconizadas a centralização e a maior participação na industrialização por parte das cooperativas e a reestruturação das relações associado/cooperativa, buscando assim o apoio dos associados. Ou seja, “(...) o objetivo que se busca com essa 'remexida' é um só: aumentar a eficiência empresarial das cooperativas e, ao mesmo tempo, criar uma estrutura forte (...)". Ver, entre outros, Agricultura \& Cooperativismo. Porto Alegre, setembro de 1980, pp.8-12. Zero Hora. Porto Alegre, 18 de julho de 1980, p.17 e Cotri jornal. Ijuí, agosto de 1980, p.23. do crescente enfrentamento mais estreito e direto entre essa classe social e o complexo agroindustrial e a rápida "urbanização" do campo. Acontece que. para a situação estrutural do campesinato, não existe um confronto imediato com outra classe, a exemplo do operariado, além do tipo de relações que se estabelece entre os mesmos no processo produtivo. ${ }^{116}$

A desmobilização política levada a efeito por essa forma de cooperativismo, em geral não se apoia na falta de discussão e participação, mas é através da manutenção e, conforme o caso, de sua intensificação que atua no sentido da persuasão e da reorientação das insatisfações e tensões sociais. $\mathrm{O}$ instrumento básico para tanto é a apresentação, perante o quadro de associados, de uma forma de desenvolvimento cuja concepção equivale essencialmente à modernização e aumento da produtividade física. Isso é complementado com a reorientação da mobilização político-ideológica no sentido de que não 'extrapole os limites das propostas e das concessões e rearranjos permitidos pelo padrão vigente da acumulação e dominação social, ou, em outras palavras, de acordo com o capitalismo associadodependente e o Estado autoritário.
${ }^{116}$ Sobre o poder de anulação das diferenças entre os camponeses que algum inimigo comum
exterior ao "mundo camponês" possui e as dificuldades ideológicas próprias do campesinato
em compreender a "macropolítica", ver Hobsbawn, Eric J., Los campesinos y la política e
Alavi, Hanza, Las classes campesinas y las lealtades primordiales. Barcelona, Editorial
Anagrama, 1976. Entretanto, discordamos de Servolin, quando conclui que "(...) não existe
luta de classes especificamente agrícolas" (Servolin, C., op. cit., p.76). Para esse autor não
haveria luta de classes porque não haveria um confronto direto entre o campesinato e os
produtores agrícolas capitalistas. Porém, o autor só toma o antagonismo entre essas duas
categorias de produtores em si como possível fonte de lutas de classe e além disso é
questionável que não haja confronto entre campesinato e burguesia rural. 


\section{Conclusões}

O processo de expansão do capitalismo na agricultura, sua articulação com o capitalismo internacional e a forma de cooperativismo abordada neste trabalho possui um alto grau de especificidade. Tanto a produção quanto as formas de realização e reprodução da dominação social, apoiadas em boa medida no cooperativismo agrícola que atua conjuntamente com o grande capital preponderantemente transnacional e com as políticas estatais, foge em boa medida dos demais padrões da agricultura brasileira.

Essa especificidade da agricultura enfocada remonta à própria história da ocupação do solo e formação da estrutura fundiária. A ocupação do solo nas colônias do Sul do Brasil e sua expansão em condições históricas determinadas resultou no estabelecimento e consolidação da pequena propriedade rural como unidade produtiva predominante. $\mathrm{Da}$ ocupação do solo nessas bases resultou, em termos produtivos, uma policultura alimentar, na qual alguns produtos representavam os excedentes comercializáveis e contribuíam para a orientação da produção.

Com o novo lugar que a agricultura passou a ocupar nos novos padrões de acumulação a partir de 1930 e em especial desde a década de 1950-, o trigo e mais tarde a soja e paulatinamente outros produtos agrícolas passaram a ser a ponta de lança da rearticulação e integração dessa agricultura com o capitalismo em geral. Essa rearticulação e essa integração reorganizam a estrutura agrária tendo em vista as novas condições técnicas e sociais da produção, induzidas pelas necessidades econômico-produtivas do capitalismo industrial urbano e coordenadas, viabilizadas pela intervenção do Estado e complementadas e mediatizadas pelas cooperativas agrícolas.

Tentamos detectar a tendência no tocante à estrutura de classes, resultante desse processo de integração da produção agrícola, tendo em vista a explicitação do contexto social em que o cooperativismo agrícola empresarialmente desenvolvido atua e do qual, em boa medida, é resultado. As condições técnicas e sociais em que se dá essa expansão do capitalismo na agricultura não provocam a proletarização, nem a concentração da propriedade fundiária de forma generalizada, a não ser num grau limitado requerido pela reorganização da produção. No tocante às relações sociais de produção, a única forma de utilização da força de trabalho que cresce em termos relativos e por vezes absolutos, como resultado desse processo, é a mão-de-obra familiar, eliminando assim, progressivamente, tanto o trabalho assalariado quanto as antigas formas de ocupação da força de trabalho, tais como o "antigo campesinato", meeiros, parceiros etc. Consequentemente, em termos de estrutura de classes, a camada social que resulta dessa forma de organização da produção agrícola é essencialmente aquilo que designamos como neocampesinato, que é a principal base social, em relação à agricultura stricto sensu, do cooperativismo agrícola empresarialmente desenvolvido, especialmente aquele vinculado à produção de trigo e soja. Paralelamente à afirmação dessa camada de produtores agrícolas, existe um processo violentíssimo de seleção/exclusão social do antigo campesinato, que potencial ou efetivamente abrange á maior parte da população rural do Sul.

Para apreender as causas básicas da não-formação de empresas capitalistas em seu sentido conceitual, embora se formem unidades produtivas altamente capitalizadas e com uma alta produtividade física do trabalho, apoiamo-nos em especial em ideias e conceitos de Servolin e Susan e Dickinson. Assim, a especificidade técnica da produção agrícola (Servolin) em determinadas condições permite um alto grau de desenvolvimento das forças produtivas sem que haja necessariamente acumulação e centralização do capital, aumento constante da área média dos estabelecimentos - a não ser para a formação do tamanho "ótimo" e proletarização na produção agrícola stricto senso. A inexistência da proletarização generalizada resulta da baixa quantidade de trabalhadores exigida pela divisão social e pela elevação da produtividade física no processo produtivo agrícola em questão, onde em geral o número de trabalhadores requerido não ultrapassa o número médio de trabalhadores de uma família de camponeses.

Essa especificidade técnica da produção agrícola deve ser entendida nas condições sociais e históricas em que se situa a produção em questão. Por isso, caracterizamos as bases históricas da formação de sua estrutura fundiária e agrária, visto que é sobre essa estrutura que as forças sociais exógenas à produção agrícola, tais como a agroindústria e as políticas estatais, atuam. Em outras palavras, a atuação dessas forças externas à produção agrícola em si, em última instância determinam a introdução de 
novos processos produtivos na agricultura assim como o tipo de tecnologia utilizada. No caso, essas condições sociais, no tocante à estrutura agrária, têm como base geral o campesinato formado pela ocupação do solo através da imigração e a constituição da pequena unidade produtiva familiar e sua gradativa integração, subordinação e readaptação pelo complexo agroindustrial e pelas políticas estatais. Entretanto, a forma dessa readaptação - bem como seus efeitos sociais - em boa medida é resultante dessas condições históricas e sociais encontradas pelo capital agroindustrial e pelas políticas estatais, visto que as formas de reação e readaptação dessa agricultura à sua integração e subordinação, tanto ao nível técnico-econômico quanto sociopolítico, se de um lado estão condicionadas pelas formas do capital agroindustrial e suas estratégias, de outro, dependem diretamente dessa situação histórica e social.

Por outro lado, ainda para explicitar as condições sociais e históricas da produção agrícola, agora em relação aos seus condicionantes mais gerais, procuramos demonstrar o grau de integração e subordinação da produção agrícola à agroindústria e à intervenção estatal. Através disso, procuramos demonstrar o poder oligopólico e de transferência de valor da agroindústria, viabilizado tanto pelo maior desenvolvimento e centralização do capital nos setores não-agrícolas, em associação com o capitalismo internacional, quanto pela atuação do Estado, enquanto viabilizador e coordenador geral da acumulação e reprodução do capital e da distribuição e apropriação dos excedentes.

E a partir desse quadro que enfocamos o cooperativismo agrícola vinculado a essa forma de produção. Em termos socioeconômicos, essa forma de associativismo, nas condições estudadas, representa um elo de ligação e articulação entre as diversas forças sociais, agentes e camadas sociais - camadas sociais melhor situadas na produção agrícola, Estado e agroindústria - envolvidas, direta ou indiretamente, com a agricultura. Portanto, nesse sentido, o cooperativismo agrícola configura-se como um agente de racionalização econômico-produtiva da integração da produção agrícola com o padrão de acumulação vigente, atuando como impulsionador do desenvolvimento das forças produtivas e sendo complementar tanto à agroindústria quanto à intervenção do Estado, se bem que subordinada e contraditoriamente. Como o padrão de acumulação vigente está assentado na associação do capital externo, estatal e privado nacional, é nesse contexto socioeconômico, com toda a gama de alianças, subordinações e conflitos de interesses específicos, que essa forma de cooperativismo desenvolve-se naqueles setores e linhas de produção ditadas pelos interesses mais amplos e lastreadas no apoio estatal, cujas políticas agrícolas complementa. O cooperativismo empresarialmente desenvolvido participa do padrão de acumulação como sócio-subordinado e com lugar definido no movimento geral da acumulação e reprodução, a exemplo do capital privado nacional, possibilitando sua rápida expansão e mesmo integração vertical em determinados setores. Nas fases de rápido crescimento econômico a própria expansão das grandes corporações transnacionais e da intervenção estatal em termos de investimentos produtivos diretos amplia espaços econômicos que podem ser ocupados pelos grupos econômicos cooperativos ou pelo capital privado nacional, pelo menos naqueles ramos ainda não preenchidos pelo grande capital, complementando-o assim.

Por outro lado, o cooperativismo agrícola nessas condições representa uma aliança de classes e passa a exercer efetivamente o lugar de canal político dos interesses das classes e camadas sociais rurais melhor situadas em termos produtivos, frente ao Estado e à agroindústria. Desse modo, nas condições políticas em que essa forma de associativismo se desenvolveu - final do período populista e consolidação do Estado autoritário - o cooperativismo politiza-se, corporativamente, ao ponto de se tornar o canal político efetivo básico dos interesses das camadas sociais rurais melhor situadas socioeconomicamente e/ou da expressão daqueles interesses que, se bem que contraditórios em relação às políticas estatais, não põem em questão o processo de acumulação e reprodução do capital. Simultaneamente, através desse canal político o Estado busca a concretização de sua intervenção. Assim, ao mesmo tempo em que esse cooperativismo serve como instrumento de mediação política, o Estado consegue por seu intermédio ter o controle e "resolver" parte das tensões sociais mais acirradas no meio rural, sem pôr em questão o padrão de acumulação vigente e sua correspondente forma de dominação política.

Por termos tratado de urna situação relativamente específica e de certa forma ainda em formação e devido aos próprios limites deste trabalho, uma série de questões fica em aberto. Uma delas, por exemplo, é a necessidade de explicitar de modo aprofundado e sistemático a existência ou não de poupança nas diversas formas de produção agrícola, sua possível 
transferência para outros setores ou reinversão na própria produção agrícola, bem como a remuneração do capital e trabalho aplicado na agricultura. Isso requer uma quantidade de dados empíricos desagregados em escassa disponibilidade e um quadro teórico que possibilite a explicação da diversidade de formas de realização do capital e sua articulação com o capitalismo internacional, da integração e subordinação da produção agrícola ao capital, bem como do resultado concreto em termos de estrutura de classes e que explicite, ao mesmo tempo, a unidade e dinâmica da expansão do capital e suas formas de subordinação do trabalho e exclusão social.

Isso tudo nos remete também à necessidade de um quadro de análise que explicite sistematicamente os mecanismos de dominação social referentes à "sociedade agrária", através dos quais é buscada pelo Estado a reprodução da dominação política e a viabilização histórica do capitalismo associado-dependente através da incorporação das diversas formas de trabalhadores rurais ao Estado burguês. Para tanto se faz necessário um quadro analítico e de um objeto que extrapole o cooperativismo agrícola empresarialmente desenvolvido e envolva, entre outras, as questões referentes à especificidade estrutural do campesinato enquanto classe social, seu corpo ideológico e sua diversidade.

Em síntese, torna-se necessária a eliminação de generalizações vazias e a priori, especialmente comuns em boa parte da bibliografia brasileira sobre a questão social na agricultura, entre as quais se ressalta a equivalência, a priori, entre expansão do capitalismo na agricultura e trabalho assalariado generalizado, sem se levar em conta a diversidade de formas de subordinação do trabalho pelo capital, a apropriação do sobretrabalho e a consequente forma de dominação social. Por outro lado, torna-se necessário explicitar as confusões ideológicas e preconceituosas das quais resultam, por exemplo, a equivalência entre propriedade privada camponesa - resultado de uma forma específica de produção, em regra com base na autoexploração - com propriedade privada capitalista ou, eventualmente, campesinato com rejeição ao capitalismo. $\mathrm{O}$ mesmo acontece com a confusão entre cooperativismo agrícola empresarial articulado e complementar ao capitalismo associado-dependente como uma proposta de transformação social e superação do capitalismo.

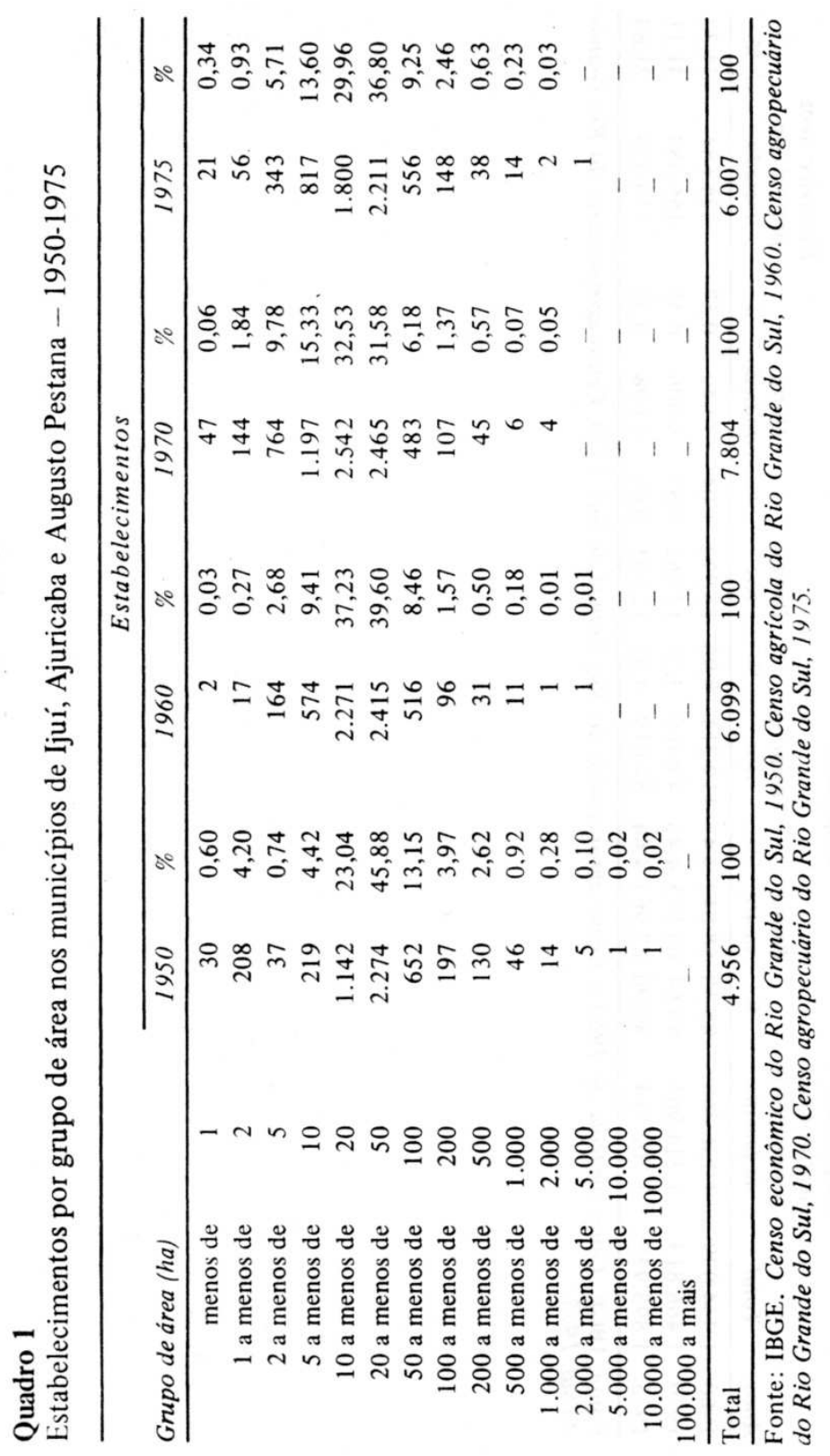



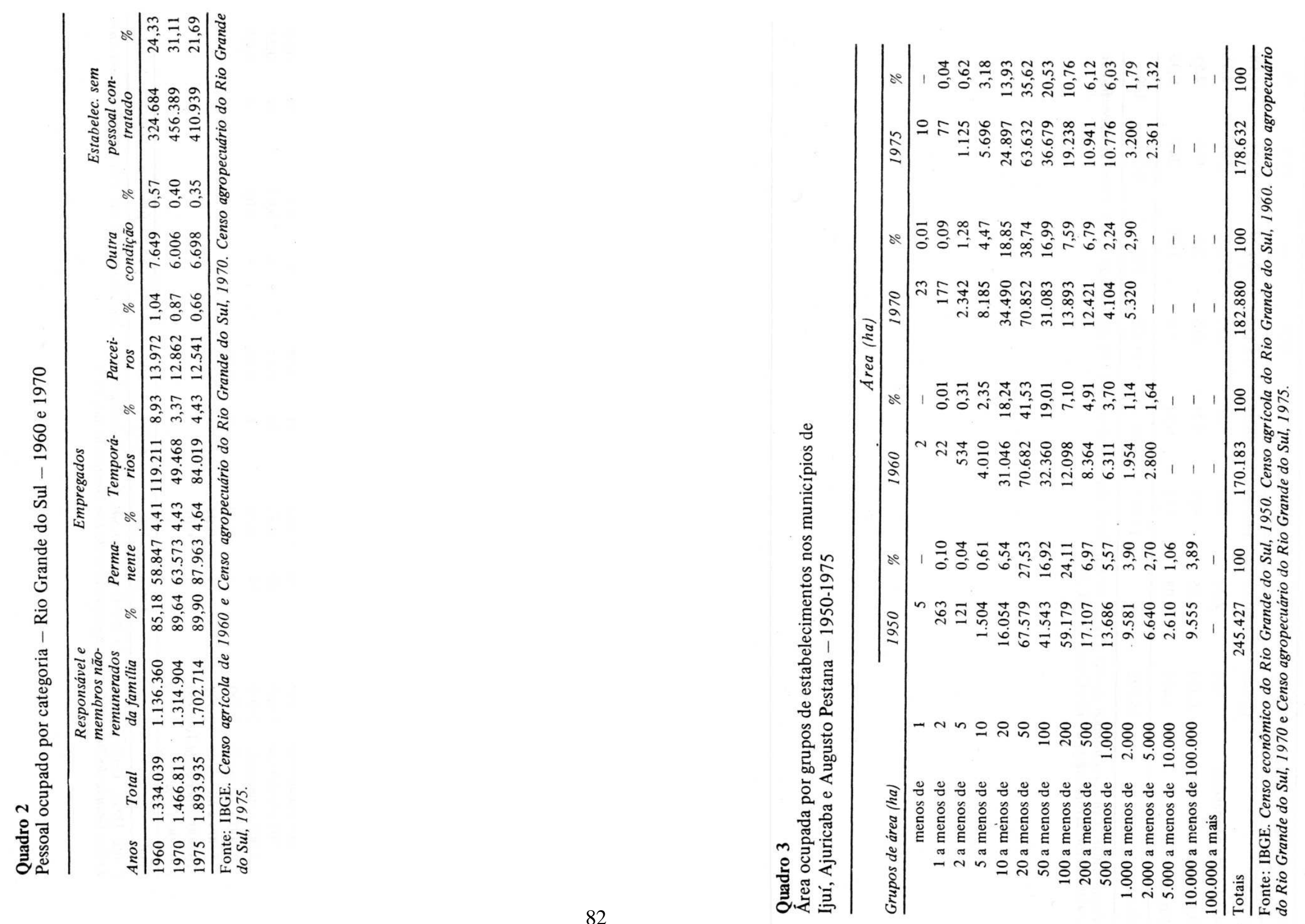

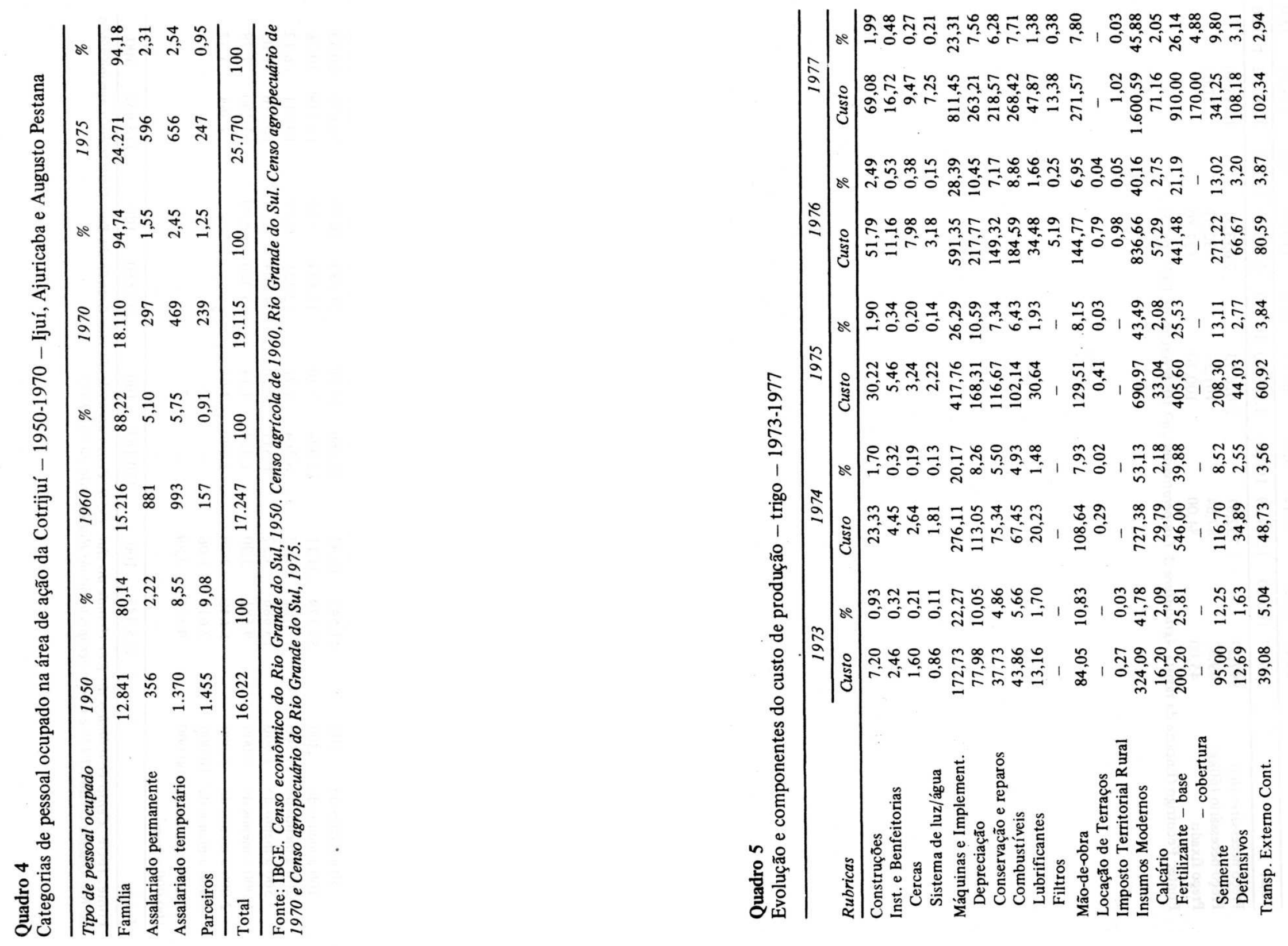


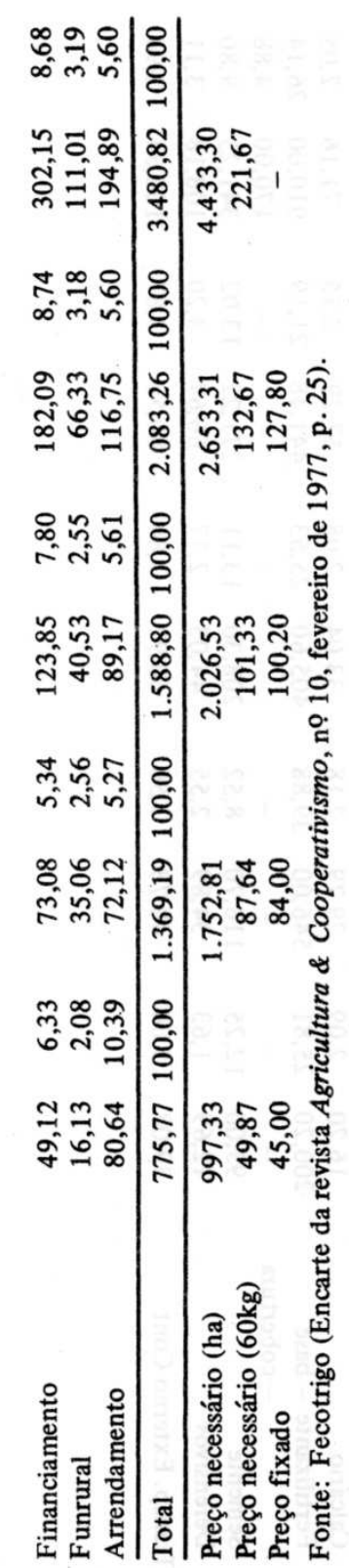

Quadro 6

Demonstrativo do custo de produção por rubrica - soja - 1977

\begin{tabular}{lrrr}
\hline & \multicolumn{3}{c}{ Custo de produção } \\
\cline { 2 - 4 } Rubricas & \multicolumn{1}{c}{ Total } & Hectare & Saca $(60 \mathrm{~kg})$ \\
\hline Construções & $10.812,57$ & 60,07 & 2,67 \\
Instalações e Benfeitorias & $2.616,13$ & 14,53 & 0,65 \\
Cercas & $1.480,87$ & 8,23 & 0,37 \\
Sistema de luz/água & $1.135,26$ & 6,30 & 0,28 \\
Máquinas e Implementos & $126.715,01$ & 703,97 & 31,29 \\
Depreciação & $42.550,66$ & 236,39 & 10,51 \\
Conservação e reparos & $33.296,96$ & 184,98 & 8,22 \\
Combustíveis & $41.320,37$ & 229,56 & 10,20 \\
Lubrificantes & $7.523,94$ & 41,80 & 1,86 \\
Filtros & $2.023,06$ & 11,24 & 0,50 \\
Mão-de-obra & $34.559,45$ & 192,00 & 8,53 \\
Imposto Territorial Rural & 182,98 & 1,02 & 0,05 \\
Insumos Modernos & $174.726,72$ & 970,70 & 43,14 \\
Calcário & $30.937,50$ & 171,87 & 7,74 \\
Fertilizantes* & $51.667,20$ & 287,04 & 12,76 \\
Semente & $38.610,00$ & 214,50 & 9,53 \\
Defensivos & $53.512,02$ & 297,29 & 13,21 \\
Transporte Externo Contrat. & $19.840,95$ & 110,23 & 4,90 \\
Financiamento** & $30.665,88$ & 170,37 & 7,57 \\
Funrural & $14.681,25$ & 81,56 & 3,62 \\
Arrendamento & $25.839,00$ & 143,55 & 6,38 \\
\hline * Descontado & & &
\end{tabular}

* Descontado o subsídio de $40 \%$.

** Financiamento de calcário, semente e defensivos isentos de juros. Fonte: Fecotrigo. 


\section{A "Babá" dos Brasileiros: uma multinacional no setor leiteiro}

Antoinette Fredericq
- Para Bernardo, Alaíde e Aninha, que me ajudaram para que este texto existisse.

- Para Felippe e os companheiros da Baronesa, que me ajudaram a sair da minha fase acadêmica.

- Para Trouc, pedaço da minha vida, que me ajudou, apesar de tudo, a chegar onde cheguei.

Ouro Preto, novembro de 1981

* Esta pesquisa foi desenvolvida durante os anos de 1978 a 1980, com a ajuda financeira da 


\section{Introdução}

\section{Subordinação da agricultura ao capital industrial e financeiro}

A produção agropecuária, hoje em dia, não é mais um setor isolado das demais atividades socioeconômicas. Depende, constantemente, do poder de decisão de entidades que lhe são estranhas: o agricultor precisa receber um financiamento bancário para comprar seus insumos e ampliar suas instalações. Ë procurado pelas firmas difusoras das tecnologias mais sofisticadas em matéria de equipamentos. E acaba vendendo sua colheita a baixo preço, sob as pressões constantes de comerciantes e industriais garantidos por uma forte posição oligopsônica. A agricultura se encontra em contato constante com o capital agroindustrial e financeiro, e esse contato não é de igualdade: a agricultura está subordinada a esses setores por mecanismos complexos e variados, que podem ser alterados em função de acontecimentos conjunturais.

No caso da maioria dos produtos agrícolas, existe um mecanismo central, pelo qual se reproduz a subordinação do produtor ao capital citado acima. Esse mecanismo é provocado pelo desajuste entre preços agrícolas e industriais. $\mathrm{O}$ preço dos alimentos é mantido artificialmente baixo, através de um controle governamental constante, para permitir a compressão do salário do operariado urbano: colabora, dessa maneira, com o processo de acumulação industrial. $\mathrm{O}$ preço dos produtos industriais acabados, ao contrário, não é controlado de maneira tão rígida, graças ao maior poder de barganha desse setor que se transformou, desde a década de 1950, no eixo de acumulação da economia brasileira. Com isto, o produtor rural acaba tendo de pagar um preço cada vez mais elevado pelos insumos e equipamentos de que precisa. Proporcionalmente, o preço que recebe por sua produção agrícola segue uma tendência nitidamente decrescente.

O resultado desse processo é o endividamento crônico de muitos produtores rurais e a necessidade de intervenção do Estado para conservar certo equilíbrio (crédito rural, garantia de preços mínimos e até intervenções na produção). ${ }^{1}$

Da mesma forma, muitas empresas transformadoras de produtos agrícolas lucram com esse fenômeno: compram suas matérias-primas a um baixo preço, garantido pelo Ministério da Agricultura, e colocam seus produtos acabados no mercado a um preço bem menos controlado. A isso se soma, ainda, o poder econômico das maiores empresas transformadoras: nesse setor, bastante concentrado, elas possuem, frequentemente, uma posição de monopsônio ou monopólio total.

A produção agropecuária não é, portanto, um setor autárquico dentro da sociedade. A agroindústria começou a comandar o processo de produção agrícola e as relações sociais na agricultura passaram a se reorganizar em função de sua integração no complexo agroindustrial. A agroindústria não só possibilitou uma melhoria na produtividade agrícola, um acréscimo na produção e um consequente aumento do potencial de extração do sobretrabalho no campo, mas desenvolveu, também, novas formas de extração desse sobretrabalho: uma vez que os produtores, anteriormente "independentes", 2 passaram a depender da agroindústria para a compra de seus insumos e para a venda de seus produtos acabados, tornaram-se subordinados a esse capital, de maneira indireta. A intensidade dessa subordinação e a forma por ela assumida dependem de vários fatores (tipo de produto, desenvolvimento das forças produtivas, intervenção do Estado etc.).

A agroindustrialização da agricultura brasileira é um processo inevitável e irreversível. O que deve ser criticado, no entanto, é a planificação do desenvolvimento agrícola do país sem um profundo controle do complexo agroindustrial que comanda a maior parte da produção rural. Não se pode esquecer a situação de crise em que se encontram os pequenos agricultores, para quem o "produzir mais", incentivado pelo Estado, muitas vezes somente é possível através de um endividamento maior, comprando insumos sofisticados que não lhes permitirão um aumento de sua renda. Não se podem ignorar os interesses ligados a esse "produzir mais", interesses orientados particularmente por

${ }^{1}$ Ver Guimarães, 1979.

${ }^{2} \mathrm{Ou}$ dependentes, unicamente, do capital comercial tradicional. 
algumas poderosas empresas oligopólicas, quase todas de capital transnacional.

No Brasil, podem ser citados como exemplo, do lado dos insumos, Ford, Massey-Ferguson, Valmet, Fiat, Mitsui, Bunge y Borne, Central Soja, Ralston Purina, Anderson-Clayton, Cargill, Bayer, Ciba-Geigy e o grupo Rockefeller; do lado do processamento industrial, Unilever, Nestlé, SwiftArmour, CPC International, Standard Brands, Del Monte, Coca-Cola, Carnation, General Foods, Borden, BsN-Gervais Danone, Ajinomoto, Kellogg etc., todas integrantes da lista das 50 maiores empresas agroalimentares a nível mundial. ${ }^{3}$

Foram essas empresas que passaram a participar de uma série de operações ligadas à produção agrícola brasileira, desde a escolha do tipo de tecnologia que colocam no mercado, até as decisões a respeito de como e quanto vai ser plantado, e de como e quanto da produção agrícola vai ser processado.

Retomando as palavras de Alberto Passos Guimarães, chegamos, aqui, a "aspectos estratégicos, que envolvem a submissão da agricultura, em todas ou na maior parte das questões de sua economia interna, às decisões das empresas multinacionais com suas subsidiárias colocadas a montante ou a jusante do complexo agroindustrial brasileiro...

Essas decisões não dizem respeito apenas a questões de natureza econômica, como, por exemplo, a captação, para as multinacionais, de grande parte da renda gerada na atividade agrícola, ao atuarem sobre mecanismos de preços para aumentar seus lucros industriais, em detrimento dos lucros da agricultura. Elas envolvem, além daqueles, questões ainda mais importantes, de natureza não-econômica, como, por exemplo, a das opções tecnológicas e a da preferência por determinados cultivos em prejuízo de outros, terreno em que os interesses das multinacionais contradizem frontalmente os interesses brasileiros" (Guimarães, 1979, p. 142).

\footnotetext{
${ }^{3}$ Essa lista se encontra em Rastoin, [s/d].
}

O capital estrangeiro na agricultura brasileira

Já bem antes do processo de transnacionalização das grandes empresas, o capital estrangeiro estava implantado na agricultura brasileira: um levantamento das empresas estrangeiras existentes no país, entre 1860 e 1913, conseguiu identificar 42 empresas ligadas ao setor agropecuário, num total de 534. ${ }^{4}$ Essas empresas se dedicavam, quase que exclusivamente, à comercialização da produção agrícola para exportação (borracha, açúcar, café).

Durante as décadas que se seguiram, mas principalmente a partir dos anos 1950, o capital estrangeiro foi-se expandindo e se diversificando em vários setores agrícolas. Desligou-se cada vez mais das atividades primárias, para concentrar-se a montante e a jusante da produção: em 1974, somente cinco das 109 maiores empresas estrangeiras estreitamente ligadas à agricultura exerciam, ainda, atividades primárias.

A partir de 1967, a penetração dessas empresas estrangeiras na agricultura chegou a alcançar um ritmo mais acelerado do que nos demais setores da economia. A totalidade dos investimentos e reinvestimentos das transnacionais "agrícolas" analisadas Por Plínio Sampaio (1977), por exemplo, superaram, em 1973-74, a soma dos 11 anos anteriores. Quanto à proporção de reinvestimentos no estoque de capital, foi de $68,9 \%$, contra $34,8 \%$ para as empresas estrangeiras ativas no resto da economia. Esses reinvestimentos são mais frequentes no ramo da industrialização de matérias-primas agrícolas.

Os dados citados acima indicam a existência de uma alta lucratividade das empresas ligadas à agricultura, e, mais especificamente, da indústria de transformação de matérias-primas. Podem, no entanto, ser relacionados também com as possibilidades de expansão desse mercado e com a política de incentivos fiscais na área.

A intervenção estatal foi essencial para a definição do lugar das empresas estrangeiras na agricultura. A reorganização do padrão de acumulação em torno do grande capital monopolístico, os incentivos à implantação do capital transnacional no país, a modernização da

${ }^{4}$ Castro, 1976; citado em Sampaio, 1977, p.49. 
agricultura, visando a integrá-la ao complexo agroindustrial, as medidas protecionistas frente aos mercados agrícolas internacionais, os incentivos à compra de terras nas áreas de fronteiras: todos esses fatores delinearam o campo de trabalho das corporações transnacionais no Brasil. A combinação dessas vantagens - proporcionadas pelo modelo econômico vigente com outras vantagens "naturais" (grandes extensões de terras agrícolas, mercado potencial considerável) tornou o Brasil um dos maiores focos mundiais de atração para o capital transnacional ligado à agricultura.

Qual é a extensão atual tomada por esse fenômeno? Segundo cálculo de Plínio Sampaio, 20 a 30\% do capital estrangeiro investido no país localizar-se-iam na produção agrícola propriamente dita, à sua jusante ou à sua montante. Essa participação, vista em termos de número de empresas, é a seguinte: das 400 maiores, 109 empresas, ou seja, 28\%, realizam atividades ligadas à agricultura.

\section{Formas de integração}

Quais são as formas concretas que adotou o capital industrial, e mais particularmente o capital industrial transnacional, em sua integração à agricultura? Na escolha entre duas opções básicas, a integração vertical (com a produção direta da matéria-prima) ou a quase-integração (em que a produção agrícola a ser processada é comprada de produtores em estabelecimentos próprios), o segundo caso é o mais comum; mas a opção por um ou outro sistema de produção dependerá de muitos fatores, como o tipo de cultura escolhido, possíveis imposições estatais etc.

A integração vertical permite um maior controle da regularidade nos prazos de entrega, da quantidade, qualidade e homogeneidade dos produtos, e pode até diminuir os custos de produção. Foi o esquema predileto da economia colonial, com plantações e enclaves integrados diretamente no processamento e na comercialização a nível mundial. No Brasil, temos, por

5 A grande maioria dessas empresas "agrícolas" é proveniente dos EUA, com uma A grande maioria dessas empresas "agrícolas" é proveniente dos EUA, com uma
preferência mareada pelos ramos de alimentação, exploração de madeira e papel. Depois das norte-americanas, as empresas mais numerosas são as japonesas, que se dedicam principalmente à comercialização de produtos agrícolas, seguidas pelo capital inglês, alemão e suíço. exemplo, os tradicionais engenhos do Nordeste, ligados ao mercado mundial do açúcar.

Agroindústrias modernas também recorreram à integração vertical para possibilitar um grau mais elevado de acumulação de capital: no setor avícola, por exemplo, o atual desenvolvimento das forças produtivas fez com que os ganhos de escala permitissem alcançar uma rentabilidade econômica maior. Em outros casos, os incentivos públicos é que determinaram a escolha desse tipo de produção. Tais incentivos foram importantes para a implantação de muitos projetos de pecuária, de reflorestamento etc., em regiões beneficiadas por incentivos fiscais.

$\mathrm{O}$ recurso à quase-integração, de outro lado, pode também ser induzido pelo Estado, ou então depender de contratos diretos entre produtores e agroindústria.

No primeiro caso, o Estado assume, da maneira mais direta possível, a organização das relações entre agricultores e indústria, chegando a controlar cada passo da produção em função de sua posterior transformação industrial. É o caso, por exemplo, da Codevasf, no vale do São Francisco (ver Sorj, 1980).

No caso da quase-integração mediante agricultura de contrato, de outro lado, a agroindústria assegura aos produtores - por contrato - o fornecimento dos insumos necessários e a posterior compra de toda a sua produção. Um exemplo típico a ser citado aqui é o da produção de fumo no Rio Grande do Sul: "No caso do fumo, as empresas [processadoras] fornecem todos os insumos necessários, controlam as sementes, fazendo pesquisa das variedades que lhes interessam, dão assistência técnica sistemática, garantem crédito, enfim, dão todas as condições de produção ao camponês, menos terra e mão-de-obra. No final da safra o camponês é obrigado a entregar para a empresa toda a sua produção aos preços fixados pela indústria" (Bueno, in Movimento, $\mathrm{n}^{\circ}$ 212).

$\mathrm{O}$ produtor, ainda formalmente proprietário de sua terra, perde, de fato, toda a sua autonomia decisória e transforma-se num simples elo da corrente agroindustrial dirigida pela empresa de transformação.

Para muitos tipos de produtos, as relações entre produtor e empresa transformadora são menos definidas e a dependência recíproca menos 
acentuada: em certos casos, a indústria transformadora não fornece insumos, em outros, não existe contrato formal obrigando o produtor a lhe entregar toda a sua colheita, ou os preços não são fixados pela indústria, e sim pelo Estado etc.

Apesar de uma "independência" maior do produtor, existe um predomínio evidente da grande empresa industrial. Esta consegue apropriarse de uma parte importante do sobreproduto gerado na produção agrícola, submetendo os produtores a seus interesses econômicos.

É o que veremos no caso escolhido aqui como objeto de estudo: o setor leiteiro. Trata-se de um assunto particularmente importante, por ser um setor essencial à alimentação popular, caracterizado, nestes últimos anos, por crises alternadas de superprodução e de escassez do produto. Tanto o setor de insumos leiteiros quanto o de laticínios estão passando por um rápido processo de concentração e são dominados por alguns oligopólios transnacionais. Os produtores, por sua vez, estão cada vez mais integrados numa economia mercantil.

Graças à importância de suas cooperativas, o setor leiteiro se tornou, também, um lugar privilegiado para o estudo das relações entre produtores, indústria de transformação e Estado.

\section{Concentração e origem do capital no "ciclo do leite"}

No caso da produção leiteira brasileira, como se apresenta a relação entre capital nacional e estrangeiro?

Podemos analisar o processo de produção leiteira como uma sucessão de momentos produtivos de vários subsetores, integrados entre si. Começa pela produção dos insumos e dos equipamentos necessários à exploração leiteira (rações para o gado, máquinas para ordenha etc.). Esse subsetor se comunica com um segundo, o da produção leiteira propriamente dita, que, por sua vez, manda seu produto final, o leite cru, para a indústria de processamento (pasteurização do leite e produção de derivados). Depois, os produtos acabados serão mandados para o setor de comercialização e, enfim, serão dirigidos para o mercado consumidor: é a essa sucessão de operações que se chama, aqui, "ciclo do leite".
O elo principal da corrente descrita é, sem dúvida, o produtor rural: ele é o responsável pela produção leiteira propriamente dita e, sem ele, os produtos lácteos nunca poderiam chegar até à mesa do consumidor.

Qual é, então, a situação desse produtor?

\section{Produção leiteira}

Informações a nível nacional podem ser encontradas no Censo Agropecuário de 1970. Segundo essa fonte, $70 \%$ dos produtores de leite ocupam áreas de menos de 50ha e se responsabilizam por $35,5 \%$ da produção. Escolhendo outro limite, o dos estabelecimentos de até 100ha, vemos que estes representam $82 \%$ do total. Tais dados evidenciam, portanto, uma produção atomizada quanto ao número de produtores, localizada principalmente em propriedades de menos de 50ha. A maior parte da produção, contudo, provém de estabelecimentos maiores.

Essas informações globais, no entanto, devem ser relativizadas e colocadas em contextos regionais bem diferentes. Estudos específicos sobre a tradicional região leiteira de São Paulo, Minas Gerais e Rio de Janeiro demonstraram que sua produção depende, principalmente, de pequenas e médias unidades familiares. ${ }^{6}$ Em Minas Gerais, por exemplo, a fragmentação da produção é retratada pelos recebimentos da cooperativa leiteira central do Estado (CCPR): $54 \%$ de seus cooperados lhe entregam uma produção que varia entre 1 e 25 litros diários.

Dados da CBCL Confederação Brasileira de Cooperativas de Laticínios (órgão político de representação cooperativista que agrupa, atualmente, as cooperativas centrais de São Paulo, Rio de Janeiro, Minas Gerais e Paraná) — permitem-nos dar mais um passo adiante na caracterização das unidades produtivas. Comparando a média diária de litros entregues por associado às suas cooperativas afiliadas, durante os últimos anos, vemos que está em redução constante, enquanto a produção total vem aumentando: parece que o leite entregue à Confederação Brasileira de Cooperativas é produzido de maneira cada vez mais

\footnotetext{
${ }^{6}$ Ver Moricochi, 1973, e Assistência Nestlé aos Produtores de Leite/ANPL, 1968 e 1973.
} 
fragmentada, em estabelecimentos cada vez menos especializados nessa atividade. $^{7}$

$\mathrm{Na}$ maior parte dos estabelecimentos citados pelo Censo de 1970, a produção leiteira representa uma atividade secundária, quando comparada, em termos de renda, à agricultura propriamente dita. É desenvolvida de maneira tradicional, ultrapassando raras vezes uma produtividade baixa (a média nacional é de 2,2 litros de leite por vaca). São poucos os produtores que conseguiram modernizar sua produção, para melhorá-la de maneira profunda. Os únicos que realmente se capitalizaram, em grande escala, durante os últimos anos, são uma minoria de grandes produtores, que apresentam garantias suficientes para se beneficiar do sistema oficial de crédito.

A situação de algumas regiões que não possuem tradição leiteira (novas áreas de Minas Gerais, Bahia e Goiás) é radicalmente diferente: temse notado ali um grande dinamismo na produção de leite, causado pelo deslocamento, para essas áreas, de importantes empresas de laticínios. De fato, parece ser mais lucrativo para elas implantar fábricas nessas novas regiões do que lutar contra os fatores estruturais (citados a seguir) que impeçam a expansão do setor leiteiro tradicional.

Tendo escolhido regiões com numeroso rebanho de corte, essas empresas deram oportunidade aos produtores para comercializar um importante subproduto de sua atividade. Contrariamente à situação observada nas bacias leiteiras tradicionais, os fornecedores, aqui, são, sobretudo, grandes produtores rurais que possuem propriedades e rebanhos bem maiores. $\mathrm{O}$ crescimento da produção leiteira nessas regiões novas compensou a queda constatada nas áreas tradicionais.

\section{O produtor no "price-cost squeeze"}

Vimos que, em decorrência da subordinação da agricultura às necessidades da acumulação industrial, foi possível tabelar os alimentos de primeira necessidade, para tentar controlar o custo de reprodução da força de trabalho industrial urbana. Dessa maneira, o preço do leite é mantido

${ }^{7}$ É claro que a utilização da média como unidade de análise coloca, aqui, o problema da diferenciação dos produtores e pode não captar a complexidade do processo em curso. artificialmente baixo e não consegue acompanhar o ritmo dos custos de produção, que sobem com muito mais rapidez. Isso pode ser ilustrado com urna análise comparativa da evolução dos preços do leite, dos insumos necessários à sua produção e da terra para pastos, na última década.

O preço oficial pago aos produtores de leite apresentou índices decrescentes até o ano de 1973, época em que foi reajustado e aumentado regularmente pelo Governo Federal. O crescimento total do preço real pago ao produtor, de janeiro de 1974 a julho de 1978, por exemplo, foi de 11,5\% (dados da Sunag).

Como se relaciona esse aumento com o preço dos insumos? Algumas informações foram conseguidas a esse respeito, em dados do Instituto de Economia Agrícola do Estado de São Paulo. Segundo esse Instituto, o aumento anual médio do preço real dos insumos leiteiros no Estado, entre 1973 e 1976, foi de 88,5\% para adubos e defensivos, $53 \%$ para vacinas e medicamentos, $46 \%$ para utensílios e combustíveis, $31 \%$ para mão-de-obra, $30 \%$ para sementes e mudas e $19 \%$ para a alimentação do gado.

De outro lado, em face da valorização constante do preço das terras agrícolas no Brasil, a compra ou o aluguel de pasto também implica um gasto cada vez maior para os pecuaristas. Em São Paulo, por exemplo, único Estado a respeito do qual se conseguiu esse tipo de dados, vemos que, para comprar um hectare de terra para pastagens, em 1971, um pecuarista leiteiro precisava ter o valor correspondente a 2,23t de leite. Para comprar a mesma quantidade de terra em 1972, 1973 e 1974, ele precisou, respectivamente, do valor correspondente a 2,58, 1,90 e 4,40t de leite in natura. $^{8}$

Esse aumento do preço dos insumos e da terra agrícola, muito superior aos acréscimos concedidos para o leite, constituiu importante fator de desestímulo para os produtores das regiões leiteiras tradicionais. A pecuária extensiva, que precisa de grandes áreas de pastos, torna-se cada vez menos rentável, especialmente quando não é acompanhada por um crescimento da produtividade conciliável com os aumentos nos custos.

${ }^{8}$ Para o ano de 1973 , essa quantidade é menor, por causa, provavelmente, dos vários subsídios introduzidos nesse ano para estimular os produtores leiteiros. 
Nessas bacias leiteiras tradicionais, então, a produção de leite foi relegada essencialmente a pequenas explorações familiares, que apoiam a comercialização do leite na produção de artigos de subsistência. A remuneração desses produtores não inclui renda fundiária, nem remuneração por seu capital: somente lhes permite a reprodução simples do processo de produção, e leva, muitas vezes, à descapitalização das unidades produtivas.

Os únicos que conseguem trabalhar com certa rentabilidade são os grandes produtores, que aproveitam a maior escala de sua produção e o crescimento natural do rebanho. Mesmo assim, muitos procuraram novas possibilidades de produção. Começaram a produzir leite B, um leite de qualidade superior, com maior teor de gordura, e cuja produção exige importantes investimentos e tecnologia mais avançada. Em oposição ao leite $\mathrm{C}$ (o leite comum), seu preço não é estabelecido oficialmente, o que permite uma significativa diferença de renda.

O processo de descapitalização das pequenas unidades produtivas das regiões leiteiras tradicionais, mencionado acima, entra em contradição com o objetivo de capitalização do campo brasileiro, desenvolvido pelo capital agroindustrial, e com os incentivos estatais que visam à regulamentação e ao aumento da produção. Resultam, dessas várias tendências, a sobrevivência cada vez mais precária das pequenas explorações tradicionais e o favorecimento das unidades médias e grandes, pela atuação do Estado e do capital agroindustrial.

\section{O setor de insumos}

O setor de insumos e equipamentos ligados à produção de leite não é homogêneo: o mercado de cada um de seus produtos apresenta características próprias. É possível, porém, destacar alguns aspectos gerais referentes à concentração do capital e à participação nacional e estrangeira no setor. ${ }^{9}$

Em todos os ramos, a dependência externa é muito importante. Para certos produtos, ela predomina sob a forma de importações: é o caso dos

\footnotetext{
${ }^{9}$ Os dados de mercado citados provêm, principalmente, de entrevistas com empresários e funcionários de organismos públicos ligados à agricultura
}

fertilizantes, responsáveis, até hoje, por grande parte do déficit do balanço de pagamentos brasileiro. É o caso, também, das práticas de inseminação artificial e de semeadura de pastagens, técnicas de uso recente no Brasil, que somente puderam ser introduzidas através da importação maciça de sementes e sêmen.

A dependência externa existe, ainda, na implantação direta de indústrias estrangeiras para a produção dos insumos. Em quase todos os subsetores, o mercado é liderado por empresas de capital transnacional. ${ }^{10}$ $\mathrm{Na}$ produção de rações, por exemplo, encontramos a Ralston Purina, a Cargill, a Central Soja, a Dreyfus e a Continental Grains. O mercado de produtos veterinários é liderado pela Bayer, a Pfizer, a Rhodia-Mérieux, a Ciba-Geigy, a Squibb e a Liquegás italiana, seguidos por muitos outros laboratórios farmacêuticos estrangeiros. $\mathrm{Na}$ área de sementes para pastagens, temos a International Basic Economy Corporation, a Dekalb e a Continental Grains. Quanto à produção de ordenhadeiras mecânicas, encontramos a Alfa-Lavai sueca e a Westphalia alemã.

Ao lado dessas empresas de capital transnacional, existem algumas indústrias nacionais de porte médio ou grande, que conseguem conviver ou, até mesmo, expandir-se nesse setor claramente dominado pelos interesses estrangeiros. O capital nacional conseguiu desenvolver-se principalmente nas áreas em que a concorrência exige capital menos concentrado e tecnologia menos sofisticada. Nesses setores, os vários tipos de capital chegaram a um funcionamento integrado, dividindo o mercado ou mesmo associando-se entre si.

O que distingue as corporações transnacionais de suas irmãs brasileiras é sua maior capacidade de diversificação e sua consequente implantação em mercados variados, além de uma clara superioridade financeira. São favorecidas, também, quando se torna necessária a aquisição de recursos ou de matérias-primas do exterior.

Quanto ao capital estatal, também entrou na produção direta de insumos agrícolas, principalmente no setor de fertilizantes, onde se tornou premente a necessidade de aumentar a produção através de grande

\footnotetext{
${ }^{10}$ Para um detalhamento maior da estrutura dos subsetores que se seguem, ver Fredericq, 1980, pp.24-29.
} 
concentração de capital. Nesse setor, também, chegou-se a vários tipos de associações entre capital estrangeiro, nacional e estatal.

Para quase todos os insumos leiteiros, o mercado é extremamente concentrado: os mercados de rações, produtos veterinários, corretivos, fertilizantes, sementes e ordenhadeiras são liderados por poderosos oligopólios, o que assegura, a essas empresas, uma maior facilidade para impor suas condições de venda, preços etc.

Muitas dentre elas fazem propaganda direta junto aos pecuaristas e têm serviços de assistência técnica cujos funcionários visitam as fazendas, para facilitar as vendas. Induzem os produtores a escolherem o tipo de tecnologia que colocam no mercado e que, muitas vezes, pode não ser o mais indicado, nem o mais econômico. No caso da indústria veterinária, por exemplo, existe uma venda indiscriminada de certos remédios, especialmente antibióticos, feita por vendedores leigos que ganham por comissão, o que levou a uma difusão muitas vezes abusiva de tais remédios.

As empresas estrangeiras, sendo as mais dinâmicas e dispondo de maiores recursos financeiros, desempenham um papel importante na modernização e na capitalização dos estabelecimentos leiteiros. Muitos de seus serviços privados de assistência técnica chegam a orientar os pecuaristas quanto à organização de sua produção, à tecnologia a ser utilizada, aos investimentos futuros etc.

Em muitos casos, a indústria de insumos e equipamentos leiteiros teve sua expansão facilitada pelo Estado: este lhe assegurou sua colaboração, através de uma nova legislação tarifária, a instalação de serviços de assistência técnica oficial, a obrigatoriedade de vacinação do rebanho, a outorga de financiamentos orientados, a fixação do preço do leite para o produtor etc. ${ }^{11}$

\footnotetext{
${ }^{11}$ A utilização de rações balanceadas foi muito incentivada pela implantação do sistema de "quota" ao produtor. Esse sistema foi introduzido para reduzir os desequilíbrios na produção de leite durante a época da seca, quando a entrega chega a ser reduzida em $60 \%$. A quota corresponde à quantidade média de leite entregue durante a seca, e é só para essa quota que o produtor tem direito ao preço estabelecido oficialmente. Para a quantidade de leite que a ultrapassa, durante os meses de safra, ele receberá um preço mais baixo. Uma produção regular de leite somente pode ser alcançada através da administração de alimentação
}

A menção que aqui se faz acerca do poder oligopólico das indústrias de insumos e de suas elaboradas estratégias de venda pode levar a uma impressão errônea sobre seu grau de penetração entre os pecuaristas leiteiros. De fato, a difusão de seus produtos foi limitada pelo processo de descapitalização crescente constatado nas bacias leiteiras tradicionais. Faltam, ao pequeno produtor tradicional, que trabalha com níveis de produtividade baixíssimos e capitalização quase nula, os recursos necessários à aquisição de muitos equipamentos. As empresas citadas tiveram, pois, de dirigir sua estratégia prioritariamente para os produtores médios e grandes que dispõem dos recursos e das garantias necessárias à modernização.

\section{Transformação industrial}

Vimos que os pecuaristas leiteiros se tornam cada vez mais dependentes das indústrias de insumos. Por outro lado, eles vendem seu produto, o leite cru, a empresas que o submeterão a um processo de transformação industrial, antes de colocá-lo no mercado consumidor.

Quanto às indústrias de transformação de leite em seu conjunto, é preciso tratar separadamente da pasteurização para consumo in natura e da posterior transformação industrial (leite em pó, iogurtes etc.). Trata-se de dois ramos com características bem distintas.

Já se mencionou o fato de que o leite in natura, produto básico da dieta popular, tem seu preço submetido a um controle oficial. Isso é verdade para cada etapa da produção e da comercialização: são controlados tanto o preço pago ao produtor como o pago à empresa pasteurizadora e ao varejista. Cada um desses agentes tem seu lucro diminuído ao máximo, garantindo, assim, a chegada do leite ao mercado consumidor ao preço mais acessível possível.

Esse controle governamental, que impõe aos produtores preços mais baixos que o valor de seu produto, permite uma importante transferência de excedentes para a posterior industrialização.

adequada às vacas durante a seca. Com essa regulamentação, o Estado participou ativamente da divulgação do uso de rações. 
As transformadoras captam, assim, o excedente gerado no setor agropecuário e fixam livremente o preço dos produtos que colocam no mercado. As pasteurizadoras, ao contrário, têm seu preço regulamentado e são obrigadas a transferir o excedente para a esfera do capital em geral. Essa tendência ainda se encontra reforçada pela posição de monopsônio e, em muitos casos, de quase-monopólio das empresas transformadoras, fato que já seria suficiente para garantir-lhes taxas de lucro superiores às taxas médias.

A partir desses dois fenômenos, chega-se a situações como a da Chambourcy, subsidiária da Nestlé e especializada na produção de iogurtes e de sobremesas lácteas, que trabalhou, em 1976, com uma rentabilidade declarada de quase $60 \% .^{12}$ Em um caso como este, aparece claramente a importância da pequena produção agrícola vinculada à agroindústria: a empresa não teria nenhum interesse em assumir, ela mesma, a produção leiteira, através de fazendas próprias, porque não poderia mais usufruir esse rebaixamento oficial do custo de sua principal matéria-prima.

Tendo feito essa divisão entre pasteurização do leite in natura, de um lado, e derivados, de outro, vemos que a essa primeira divisão corresponde outra: enquanto a pasteurização é feita unicamente por empresas de capital nacional privado e cooperativas, as empresas estrangeiras se encontram no segundo grupo. Elas se concentram nesse ramo mais dinâmico e lucrativo, seja diretamente na produção (por exemplo, Nestlé, Leite Glória), seja por contratos de fornecimento de know-how e assistência técnica a empresas nacionais de laticínios. ${ }^{13}$

${ }^{12}$ Quem é quem na economia brasileira, 1977. A rentabilidade é calculada como a razão do lucro disponível sobre o patrimônio líquido.

O estudo de Pires e Bielchowsky, 1977, pp.29-31, com base no Censo de 1970, analisou os custos de produção de leite pasteurizado e de vários outros produtos leiteiros, e evidenciou que a diferença de preço é muito maior que a diferença de custos, implicando uma rentabilidade bem maior dos derivados.

${ }^{13}$ Desde o início da década de 1970, com a aparição dos derivados sofisticados no mercado, as associações de empresas nacionais com estrangeiras se multiplicaram rapidamente. $\mathrm{O}$ exemplo foi dado pela associação da Laticínios Poços de Caldas com a Gervais-Danone francesa, seguida pela Mococa, que se associou à empresa italiana Parmalat, pela Polenghi, com o grupo francês Bongrain-Gérard etc. As cooperativas não ficaram para trás: a Cooperativa Central de Produtores de Leite (CCPL), por exemplo, lançou o "Yoplait", iogurte da Société de Diffusion de Marque.
$\mathrm{Na}$ estrutura de mercado dos vários derivados, aparecem, nitidamente, a concentração e o domínio das empresas transnacionais no setor. $^{14}$

Do mercado de leite em pó, por exemplo, $75 \%$ pertencem à Nestlé. Até os anos 1950, essa empresa tinha um controle quase absoluto do mercado. Em meados dos anos 1970, compartilhava os $25 \%$ restantes com a Leite Glória (subsidiária da Standard Brands, norte-americana), a Vigor (nacional), a Gervais-Danone (francesa) e outras. Quanto ao mercado específico do leite infantil modificado, o controle da Nestlé era de quase $100 \%$.

A Nestlé dominava, também, o mercado de leite condensado e o de creme de leite esterilizado. Tradicionalmente, era a única produtora. Desde 1977, no entanto, uma empresa nacional, a Mococa, conseguiu uma participação de 5 a $10 \%$ no mercado desses dois produtos. Para isso, no entanto, teve de lançá-los "idênticos em qualidade, preço e até mesmo apresentação de embalagem" aos de sua concorrente. ${ }^{15}$

O mercado de iogurte e de sobremesas lácteas é liderado pelos produtos Danone. Como esta foi a primeira empresa do país a colocar tais produtos no mercado, a partir de 1970, conseguiu facilmente dominá-lo e pôde fixar seus preços a um nível que lhe garantisse uma grande margem de lucro. ${ }^{16}$ Seu sucesso estimulou outras empresas a imitá-la e, no final da década de 1970, tinha como principal concorrente, a Chambourcy/Nestlé, seguindo-se a Vigor, as Cooperativas Centrais paulista, carioca, mineira e outras.

A indústria de queijo, ao contrário dos derivados anteriormente citados, constitui uma área muito tradicional no setor de laticínios. Existem algumas empresas médias e grandes, que se responsabilizam pelo

${ }^{14}$ Os dados citados são provenientes de entrevistas com empresários e com funcionários ligados ao setor de laticínios, principalmente no Estado de São Paulo.

${ }^{15}$ São as palavras do próprio diretor comercial da empresa (Gazeta Mercantil, 2 de fevereiro de 1977).

${ }^{16}$ A Gervais-Danone se associou, naquele ano, a uma tradicional empresa mineira, a Laticínios Poços de Caldas. As vendas dos iogurtes Danone superaram logo todos os recordes do grupo francês: graças a importante campanha publicitária, depois de dois anos de implantação, o Brasil já constituía o terceiro mercado da Gervais-Danone, perdendo somente para a França e a Alemanha. 
abastecimento das metrópoles, e inúmeras "microindústrias", que vendem seus produtos para um reduzido mercado local ou regional. A produção de queijos tradicionais está, pois, até hoje, nas mãos de empresas nacionais. Os únicos queijos que atraíram as estrangeiras foram os finos, de luxo: também nesse caso, elas se estão dedicando aos produtos mais sofisticados, dirigidos às classes urbanas de alto poder aquisitivo e que lhes garantam taxas de lucro mais elevadas.

\section{Papel do Estado}

Já se lembrou a ação do Estado na difusão de modernos insumos leiteiros. Seu papel é essencial, também, na transferência dos excedentes gerados na área agrícola, para as indústrias de transformação ou, no caso da pasteurização, para a esfera do capital em geral.

O elemento central no processo de captação desses excedentes reside na fixação do preço do leite abaixo de seu valor. O preço do leite é um preço político, elaborado em função das relações de força dentro da economia em geral, e do setor de laticínios em particular.

Estado não só determina o preço do litro de leite, mas também exerce um controle sobre as cooperativas, influencia o desenvolvimento das empresas agroindustriais etc.; enfim, desempenha um papel essencial, por ação ou omissão, ao resolver os conflitos de interesses entre os vários atores do setor leiteiro.

Dentro da cadeia agroindustrial descrita acima, o subsetor de produção do leite cru é o mais fracionado. Os produtores de leite são ligados, de um lado, ao subsetor de insumos, muito concentrado e liderado por oligopólios estrangeiros. De outro lado, vendem seu produto para empresas de transformação pertencentes ao setor de derivados controlado por oligopólios transnacionais - ou de pasteurização - nas mãos de indústrias nacionais privadas ou de cooperativas subsetor de produção do leite cru aparece, pois, como um elo mais fraco dessa corrente, controlado pelo Estado e confrontado com indústrias de grande poder econômico e financeiro.

\section{Importância da Nestlé no "ciclo do leite" brasileiro}

Este trabalho se propõe estudar a atuação de uma empresa específica dentro do setor leiteiro. Trata-se da Nestlé. Essa empresa não foi escolhida em função de sua representatividade, mas, sim, por causa de sua enorme influência no setor. Ou, para citar as palavras de um alto funcionário do Ministério da Agricultura: "É impossível, hoje, planejar uma política leiteira para o país que não leve em conta o poder da Nestlé".

\section{Em que consiste esse poder?}

Instalada no Brasil desde 1921, recebendo uma produção de mais de 3 milhões de litros por dia e controlando $75 \%$ do mercado de leite em pó, a empresa conseguiu influenciar profundamente a estrutura do setor leiteiro brasileiro, com sua atual relação entre pasteurização e produção de derivados.

Em certos países, a instalação de uma fábrica de leite em pó se dá somente quando existe excesso na produção leiteira. No Brasil, ao contrário, o impulso dado às empresas de transformação tem sido primordial, e assistimos a situações tão paradoxais quanto a instalação (beneficiada por incentivos fiscais) de grandes fábricas em regiões de escassa produção leiteira, valendo-se do argumento de que são importantes consumidoras de leite em pó.

A Nestlé, maior representante da indústria de transformação de leite, compra grande parte da produção de leite do país para transformá-la em derivados. Com isso, provoca escassez de leite fluido no mercado. ${ }^{17} \mathrm{Um}$ produto essencial à alimentação popular é desviado para a produção de laticínios cada vez mais diversificados e sofisticados, destinados a uma pequena parcela da população. São produtos "de luxo", apesar de serem comprados, também, pelas camadas mais pobres: não são essenciais a um regime alimentício básico e, muitas vezes, sua aquisição leva a gastos que diminuem o consumo de outros alimentos, de maior poder nutritivo. A empresa acaba impondo hábitos alimentares próprios aos países "desenvolvidos", colaborando, dessa maneira, para uma queda do nível geral de nutrição.

${ }^{17}$ Voltaremos à controvérsia que se desenvolveu em torno desta afirmação. 
A Nestlé, evidentemente, não é a única empresa que apresenta o comportamento aqui descrito: no Brasil, a falta de incentivos ao setor de pasteurização provocou um crescimento constante do volume de leite destinado à produção de derivados. Segundo estimativa do Ministério da Agricultura, essa proporção, que representava $50 \%$ do volume total produzido em 1975, já tinha aumentado para 67\% em 1978.

Todas as empresas brasileiras de laticínios dependem, para sua expansão (ou mesmo para sua sobrevivência), da produção de derivados. Mas um dos fatores que, sem dúvida, contribuíram para a falta de incentivos ao setor de pasteurização foi a presença antiga da Nestlé nas principais bacias leiteiras do país. Esta dificultou, desde o início, o surgimento de cooperativas com maior poder de barganha, que poderiam defender uma política oficial voltada para o leite líquido, uma vez que elas sempre foram as principais comercializadoras desse produto. ${ }^{18}$

A procura de leite para fabricação de derivados, nas bacias leiteiras próximas às metrópoles, provocou uma séria diminuição do leite fluido disponível nesses mercados. A falta de leite pasteurizado na Grande São Paulo foi estimada, por exemplo, em plena época de safra de 1977, em 500 mil litros diários. ${ }^{19}$

Como resolver o problema da escassez de leite nos grandes centros consumidores? Isso vem sendo feito graças a importações regulares e crescentes de leite em pó. Aqui, de novo, somos confrontados com a presença da Nestlé: várias de suas filiais espalhadas pelo mundo são fornecedoras do leite que será importado pelo Governo brasileiro, para suprir o déficit interno. ${ }^{20}$

O círculo acaba por se fechar: a Nestlé, uma das principais empresas responsáveis pela falta de leite pasteurizado no mercado, fornece uma parte do pó que vai ser reconstituído em leite fluido, para compensar a falta existente.

Essa rápida descrição de situações ligadas ao mercado de leite basta para justificar a escolha do tema da presente pesquisa.

\footnotetext{
${ }^{18}$ Souza, 1979.

${ }^{19}$ Estimativa do Ministério da Agricultura

${ }^{20}$ Ver nota ${ }^{\circ} 17$.
}

Conteúdo deste estudo

O primeiro capítulo tratará brevemente da implantação e da evolução da Nestlé no Brasil. Descreverá sua estrutura financeira, sua estratégia empresarial e sua evolução patrimonial. Seguir-se-á, depois, uma descrição da atuação da Nestlé no mercado leiteiro nacional.

Em uma segunda parte, mais extensa, analisaremos a posição dessa empresa transnacional nas várias etapas do "ciclo do leite", já mencionado.

Duas etapas desse ciclo foram escolhidas para serem aprofundadas em capítulos específicos: o segundo analisa as relações existentes entre a empresa e seus fornecedores de leite; o terceiro, sua atuação no mercado consumidor.

O estudo do contato que a Nestlé estabelece com os produtores rurais é essencial: através dele, chegaremos aos problemas gerais da pequena produção ligada à agroindústria. Essa pequena produção, organizada ou não em cooperativas, depende fortemente de suas empresas compradoras e dos mecanismos desenvolvidos para consolidar sua dependência. É o que veremos no caso particular dos fornecedores desse grupo transnacional.

Depois, seguir-se-á uma análise da atuação da Nestlé no mercado alimentar nacional e de sua influência nos hábitos de alimentação popular. Esse processo será estudado através de um caso particularmente interessante: o da substituição do aleitamento materno pela alimentação artificial de recém-nascidos, no Brasil.

Esta última parte analisará a mudança de comportamento dos consumidores, quando confrontados com a colocação de novos produtos no mercado. Veremos como a empresa se aproveita, de maneira ativa, de uma corrente ideológica mais ampla, ligada ao processo de acumulação do capital industrial. 


\section{A Nestlé: empresa líder do setor alimentício brasileiro}

A Nestlé representa o segundo grupo alimentício mundial (depois da Unilever) e já foi qualificada de "a mais internacional das multinacionais": realiza 97\% dos seus negócios fora de sua sede administrativa, a Suíça, e tem 303 fábricas no mundo inteiro, entre as quais 104 em 30 países periféricos (1974). ${ }^{1}$ Dos seus 146 mil empregados, só 5 mil trabalham na Suíça (contra 9 mil no Brasil). Para dar uma ideia de seu domínio dentro desse país, basta dizer que sua cifra de vendas ultrapassa as despesas totais das finanças federais suíças (Arbeitsgruppe Dritte Welt Bem, 1976). Sua história é uma longa enumeração de incorporações de empresas suíças e estrangeiras. $^{2}$

Somente $31,0 \%$ de suas vendas são provenientes de países periféricos, dividindo-se entre a América Latina (44,2\%), a Ásia $(41,6 \%)$ e a África (14,2\%), em 1978. Essa proporção pode parecer pequena, em vista da ênfase dada pelo grupo suíço à sua expansão nessas partes do mundo.

${ }^{1}$ As informações gerais sobre a atuação da empresa no mundo e no Brasil foram recolhidas das seguintes fontes principais: Arbeitsgruppe Dritte Welt Bern, 1976; Nestlé, 1975; Iffiand e Stettler, 1973; Entreprise, 5 de junho de 1971; Exame, março de 1971; Fortune, 13 de fevereiro de 1978; Exame, 26 de setembro de 1979.

${ }^{2}$ As principais empresas incorporadas foram as seguintes:

1905: Anglo-Swiss Condensed Milk Company

1929: Peter, Callier, Kohler Chocolats Suisses

1947: Maggi Alimentana (Suíça; produção de sopas)

1951: Lamont Corliss (EUA; chocolates)

1960: Crosse e Blackwell (Grã-Bretanha; enlatados, chás e geleias)

1960: Locatelli (Itália; queijos)

1962: Findus (Suécia; congelados; participação da Nestlé de 80\%)

1963: Libby, Mc Neill \& Libby (EUA; frutas enlatadas; controlada $100 \%$ pela Nestlé em 1975)

1971: Ursina-Frank (Suíça; laticínios). A absorção desse grupo acarretou o controle pela Nestlé do importante Handelsbank de Zurique.

1973: Stouffer Corp.(EUA; alimentos e cadeia de hotéis).

A Nestlé ainda tem participação majoritária em várias empresas, entre as quais podemos citar a Roustang francesa, a Sarotti italiana etc. A lista anterior não é completa, mas enumera somente as principais firmas controladas por holding suíço.

Quanto a suas participações minoritárias, podemos dizer que a empresa também está presente em firmas de renome tais como a Vittel e a Chambourcy. Em 1974, comprou, também, $49 \%$ das ações da Gesparal, que controla, por sua vez, 51\% do capital da L'Oréal, grande firma francesa de cosméticos, sabões etc.
Ela se explica, no entanto, pela incorporação recente de grandes empresas que não tinham tal preocupação (Findus, Locatelli, Ursina-Franck) e também pelo fato de que a Nestlé produz alimentos bastante sofisticados, que tradicionalmente encontram seus mercados principais na América do Norte e na Europa. Colocada essa ressalva, a progressão das atividades do grupo suíço nos países menos industrializados é uma constante e parece ser uma tendência a longo prazo.

A nível mundial, a Nestlé tem, como principais linhas de produção, bebidas desidratadas e líquidas, laticínios e sopas, caldos e refeições prontas. Sua tendência é dar cada vez mais importância aos alimentos "modernos" e de fácil preparação. No período de 1958 a 1967, por exemplo, a produção de alimentos instantâneos teve um aumento de $129 \%$, e a de pratos feitos, sorvetes e congelados, de $584 \%$, enquanto os laticínios só aumentaram em $42 \%$.

A filial brasileira parece estar seguindo a tendência de sua matriz quanto a essa diversificação da produção: a dependência da empresa em relação à matéria-prima leite está diminuindo cada vez mais, em benefício de produtos sofisticados para consumidores de altas rendas.

\subsection{No caminho da diversificação}

Como se deram a implantação e a evolução da Nestlé no Brasil? Ela foi uma das primeiras grandes empresas estrangeiras ligadas à agricultura que se instalaram no país. ${ }^{3}$ Antes, a empresa já comprara uma pequena fábrica de laticínios na Austrália, mas foi a sua implantação, em 1920, no Brasil, que realmente significou o início de suas atividades no "Terceiro Mundo". Primeiro, a nova filial se encarregou de importar e distribuir alimentos, e, no ano seguinte, comprou uma das duas fábricas de leite condensado existentes no país, em Araras (SP). Nessa época, e durante mais de 30 anos, dedicou-se quase exclusivamente à industrialização do leite, começando a fabricar, depois do leite condensado, farinha láctea, leite em

\footnotetext{
${ }^{3}$ As primeiras se implantaram durante a década de 1920 (Anderson-Clayton, Swift Armour, British American Tobacco), com raras exceções, como a Bunge y Borne, que já estava no país desde 1905.
} 
pó e diversas variedades dietéticas (com a aparição, no entanto, do chocolate solúvel em 1932).

A verdadeira diversificação começou em 1953. A estratégia empresarial da Nestlé brasileira se orientou, então, para um claro aumento das variedades de seus produtos. Em 1953, lançou-se, como pioneira no Brasil, à produção de café solúvel. Durante vários anos, a empresa teve de combater a oposição do poder público temeroso da concorrência que essa nova indústria criaria para o consumo de café em grão. Contudo, o Governo acabou incentivando os experimentos da empresa suíça nessa área, porque necessitava de uma bebida instantânea adequada para suas rações militares. Atualmente, a cota de café concedida pelo Instituto Brasileiro do Café à empresa é de 400 mil sacas por ano, das quais $75 \%$ se destinam ao mercado interno e $25 \%$ à exportação.

Em 1958, a Nestlé entrou no ramo de chocolates, através da aquisição de uma fábrica paulista e, em 1962, iniciou a produção de caldos, sopas desidratadas e condimentos. O passo seguinte foi a compra de uma fábrica de biscoitos em 1967, e sua consequente entrada nesse mercado. Em 1971, expandiu-se para a área de congelados (peixes e camarões), graças a incentivos fiscais concedidos pela Sudepe. No ano seguinte, lançou-se no mercado de sorvetes do Rio de Janeiro e de São Paulo, e começou também a produzir iogurtes, leites gelificados e sobremesas lácteas. Foi durante a década de 1970 que a empresa escolheu realmente o caminho da diversificação. ${ }^{5}$ Depois dos peixes congelados, dos sorvetes e dos iogurtes, também começou a produzir alimentos infantis preparados e entrou no ramo das águas minerais. Numa entrevista ao Jornal do Brasil, o diretor-geral da filial brasileira do grupo declarou mesmo estar pensando no "ingresso da companhia na área da soja, através de joint-venture com uma empresa já

${ }^{4}$ O café solúvel "Nescafé" é o principal produto de exportação da filial brasileira, seguido pelo chocolate solúvel "Nescau" e pelo leite condensado. Essas exportações têm pouca significação dentro da produção global da empresa, que é quase toda dirigida para o mercado interno: nem representa $3 \%$ das vendas. No entanto, em números absolutos, as exportações da empresa, em 1976, foram de mais de 13 milhões de dólares, o que significa um acréscimo de $253 \%$ sobre o ano anterior.

${ }_{5}^{5}$ Ao lado dos produtos alimentícios vendidos com a marca Nestlé, a empresa controla, atualmente, as sopas Maggi, os biscoitos São Luiz, os congelados Pescai, os sorvetes Yopa, os iogurtes e as sobremesas lácteas Chambourcy, a água mineral Minalba e o tempero para carnes Grill. operando no país nesse setor". ${ }^{6}$ Além disso, a empresa prepara hoje o lançamento de chás instantâneos e sucos de frutas congelados.

Vê-se que o grupo suíço tem penetrado em novos setores por duas vias diferentes: tanto pela incorporação de fábricas existentes, que já dispõem de uma infraestrutura produtiva montada e de um determinado mercado consumidor, quanto pela montagem de novas indústrias, aplicando nelas o know-how adquirido em outras partes do mundo. É importante também notar que a empresa não esclarece os consumidores sobre a importância exata da produção que controla, provavelmente para não realçá-la: os consumidores brasileiros não suspeitam que produtos tão diversos quanto água mineral, peixes congelados, sopa de preparo instantâneo, tempero para carnes e sorvetes são produzidos por uma mesma empresa.

\subsection{Primeira empresa alimentícia brasileira}

A Nestlé, que começou aqui com uma fábrica, em 1921, já tinha, em 1976, 16 fábricas funcionando em São Paulo, no Rio de Janeiro, em Minas Gerais e no Rio Grande do Sul, empregando mais de 7 mil pessoas. Dessas 16 fábricas, oito produzem laticínios e dependem do fornecimento de produtores de leite de suas regiões de implantação (ver Quadro 1).

Ultimamente, a empresa está-se expandindo territorialmente, penetrando em regiões menos industrializadas, deixando-se influenciar pelos promissores incentivos fiscais governamentais. Na área da Sudene, por exemplo, implantou recentemente uma fábrica destinada à produção de leite em pó e semi-industrializados de cacau. Em fase de elaboração, existe também um projeto, dependendo da Sudam, para a implantação de uma fábrica de leite em pó no município de São Miguel do Guamá (Pará). Tratase de regiões tradicionalmente não-leiteiras, onde a empresa deverá criar novas bacias desse produto.

Do ponto de vista de sua organização técnica, essas fábricas assumiram um caráter cada vez mais polivalente: não se restringem mais à produção de um tipo de derivado de uma matéria-prima específica. Elas

${ }^{6}$ Jornal do Brasil, 22 de dezembro de 1976 
associam a transformação de vários subprodutos criados durante um mesmo processo produtivo, ou, então, a transformação de várias matérias-primas diferentes.

Quanto a informações sobre a evolução do capital da filial brasileira da Nestlé, os dados do Quem é quem na economia brasileira, de 1977, dãonos certa ideia de seu crescimento. Seu patrimônio líquido, indicado pelos balanços relativos ao período de 1970 a 1976, teve um crescimento anual de mais de $10 \%$. Não se deve esquecer, no entanto, que se trata aqui da empresa "em sentido estrito", representada unicamente pela Companhia Industrial e Comercial Brasileira de Produtos Alimentares (Cicobra) ${ }^{7}$ e que são os números que ela mesma tem declarado oficialmente.

\footnotetext{
${ }^{7}$ Ver o organograma da p. 120 e o Quadro 5.
}

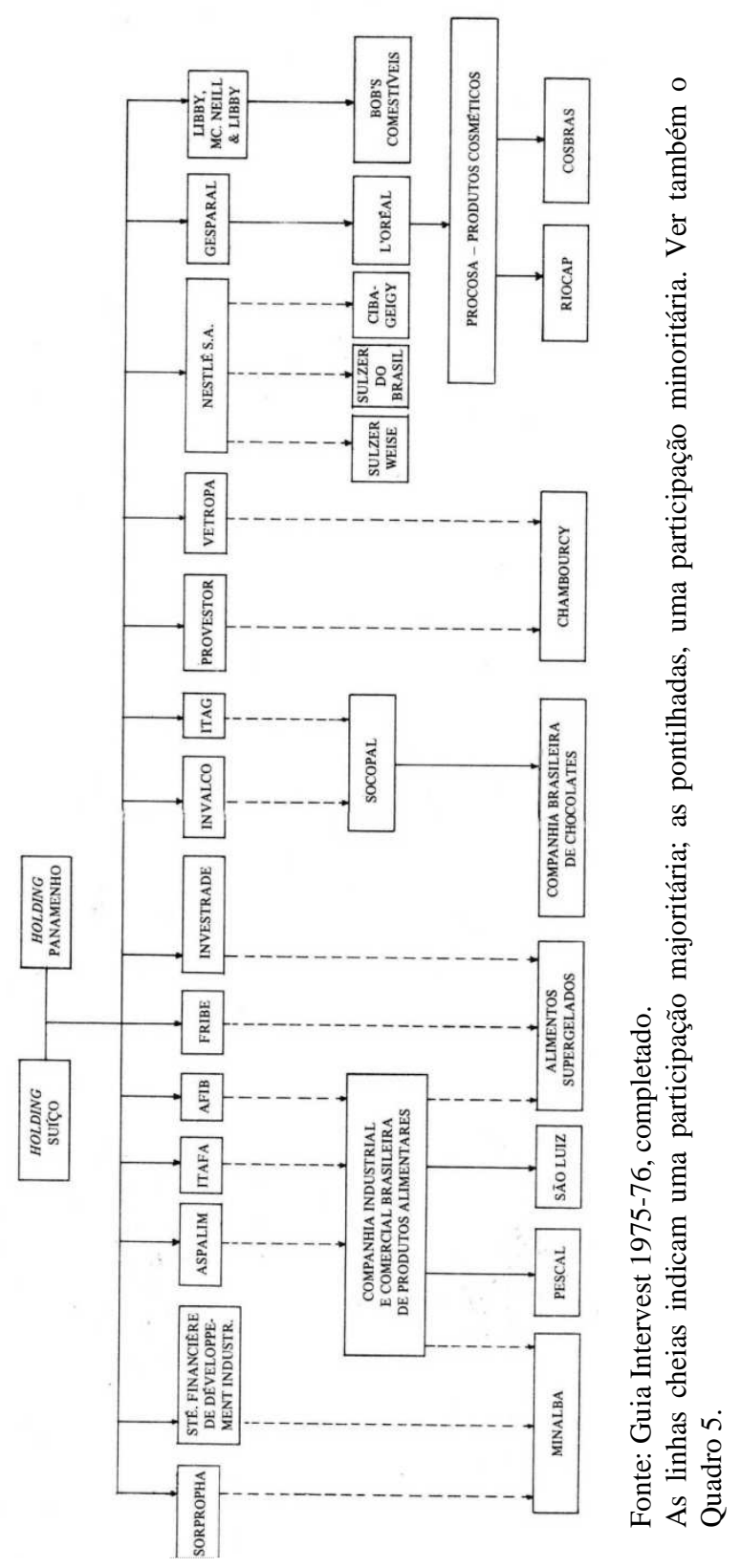




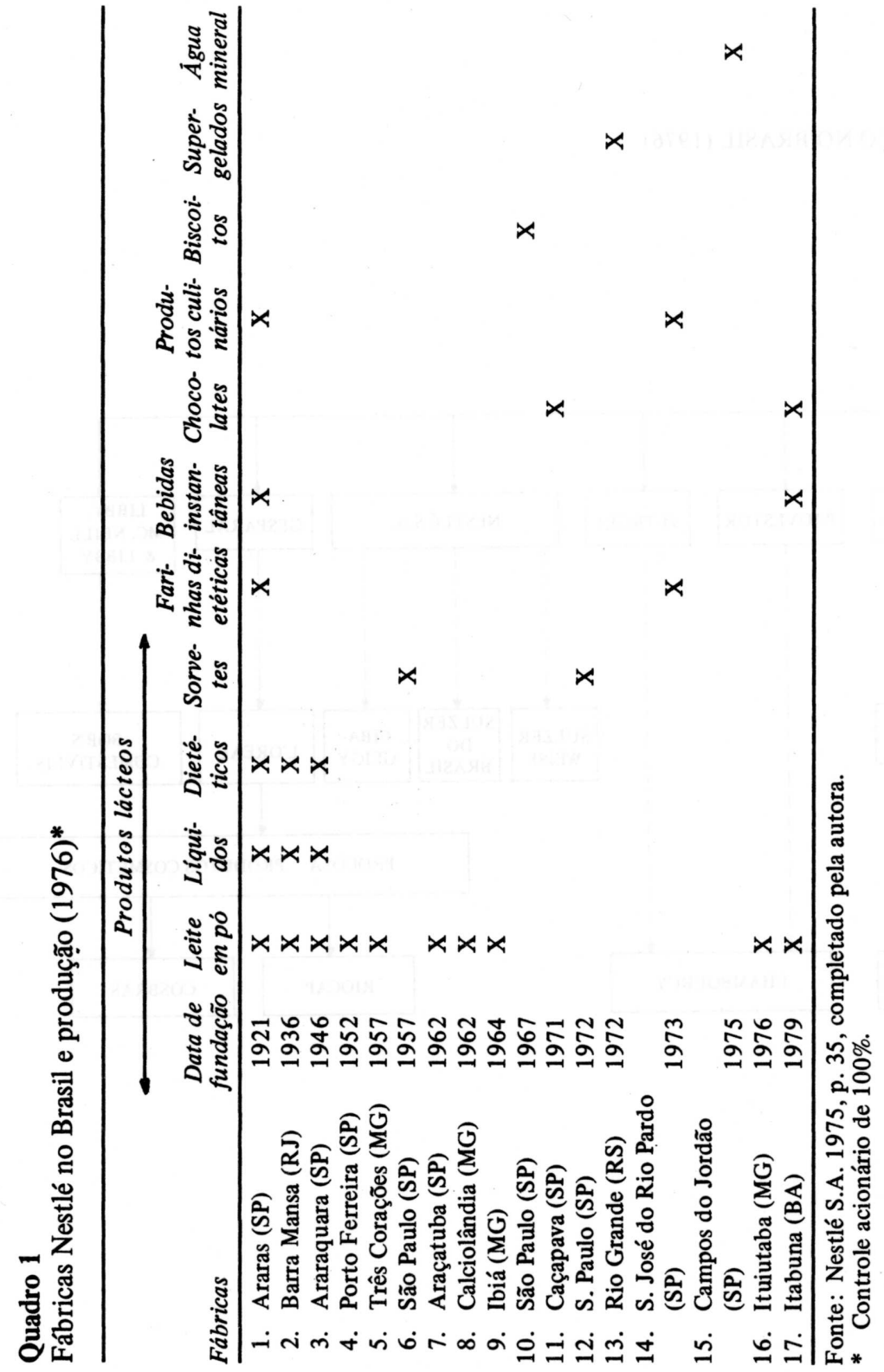

Quanto ao faturamento total da Cicobra e ao seu lucro líquido, ambos conheceram um crescimento constante. Notamos uma diferença entre o lucro líquido e o aumento patrimonial anual. Essa diferença deve corresponder às remessas para o exterior, declaradas pela empresa.

Quadro 2:

Cicobra: Patrimônio líquido, faturamento e lucro líquido ${ }^{8}(1970-76)$

\begin{tabular}{cccccc}
\hline Ano & \multicolumn{2}{c}{$\begin{array}{c}\text { Patrimônio líquido } \\
\text { deflacionado }\end{array}$} & \multicolumn{2}{c}{ Faturamento deflacionado } & $\begin{array}{c}\text { Lucro líquido } \\
\text { deflacionado }\end{array}$ \\
\hline & $\begin{array}{c}\text { Valor (Cr\$ } \\
\text { Crescimento } \\
\text { anual (\%) }\end{array}$ & $\begin{array}{c}\text { Valor (Cr\$ } \\
1000,00)\end{array}$ & $\begin{array}{c}\text { Crescimento } \\
\text { anual (\%) }\end{array}$ & (Cr\$ 1000,00) \\
\hline 1970 & 162,8 & - & 556,9 & - & 29,1 \\
1971 & 174,9 & 10,7 & 616,7 & 11,1 & 46,1 \\
1972 & 192,0 & 10,9 & 782,6 & 12,6 & 45,5 \\
1973 & 249,7 & 13,0 & 913,5 & 11,7 & 67,9 \\
1974 & 251,7 & 10,0 & 1063,8 & 11,6 & 85,1 \\
1975 & 274,3 & 10,1 & 1222,6 & 11,5 & 83,8 \\
1976 & 315,6 & 11,5 & 1276,5 & 10,4 & 134,1 \\
Média & - & 11,0 & - & 11,5 & - \\
\hline
\end{tabular}

Fonte: Elaboração da autora, a partir de Quem é quem, na economia brasileira, 1971, 1972 e 1977, e Brasil industrial, 1977-78.

Deflator: Coluna 2, Conjuntura Econômica, julho de 1978, FGV.

Um último dado que encontramos no Quem é quem na economia brasileira é o que indica a rentabilidade da empresa. Notamos que essa rentabilidade vem crescendo de maneira regular, ilustrando o lucrativo desempenho da Cicobra: quase duplicou em quatro anos, chegando a 30,5\% em 1975. Como dado comparativo, podemos lembrar que a rentabilidade média das empresas alimentícias relatadas no Quem é quem de 1977 é de $21,7 \%$, sendo que se trata aqui somente de sociedades anônimas com capital registrado de mais de 1 milhão de dólares. Quanto às outras subsidiárias brasileiras do grupo, algumas têm uma rentabilidade maior ainda. A declarada pela Chambourcy, por exemplo, no mesmo ano, é de 59,5\%.

\footnotetext{
${ }^{8}$ O patrimônio líquido é formado, segundo a fonte, pelo capital social + reservas capitalizáveis + lucro + passivo pendente - ativo pendente. $\mathrm{O}$ faturamento indica a soma de todas as rendas do ano e o lucro líquido é definido, pela fonte, como o lucro bruto (a diferença entre o faturamento e o custo dos produtos) menos as despesas não-apropriadas diretamente ao custo dos produtos vendidos, mas acrescido de todas as outras receitas e da reversão de provisões feitas em exercícios anteriores e não-aproveitadas para seus fins específicos.
} 
Os índices de desempenho da Nestlé no Brasil contrastam não somente com a média nacional do setor alimentício, mas são também superiores às médias apresentadas pelo conjunto das empresas do mesmo grupo no mundo inteiro.

Quadro 3: Cicobra: Rentabilidade (1972-76)

\begin{tabular}{cc}
\hline Ano & Rentabilidade \\
\hline 1972 & 16,6 \\
1973 & 21,2 \\
1974 & 28,2 \\
1975 & 30,5 \\
1976 & 30,3 \\
\hline
\end{tabular}

Fonte: Quem é quem na economia brasileira, 1977.

Quadro 4: Desempenho da Nestlé no Brasil e no mundo (1978)

\begin{tabular}{lcc}
\hline & Quadro 4: Desempenho da Nestlé no Brasil e no mundo (1978) & \\
\hline Crescimento de vendas & $22,0 \%$ & Grupo \\
Rentabilidade do patrimônio & $23,0 \%$ & $-2,7 \%$ \\
Rentabilidade das vendas & $4,2 \%$ & $18,1 \%$ \\
Liquidez & $1,3 \%$ & $3,7 \%$ \\
Capitalização & $53,0 \%$ & $1,4 \%$ \\
\hline
\end{tabular}

Fonte: Exame, 26 de setembro de 1979.

Em todas as classificações que foram feitas das empresas alimentícias que operam no Brasil, a Nestlé ocupa o primeiro lugar. Tanto no que diz respeito ao tamanho de seu patrimônio líquido ( 84 milhões de dólares em 1977) quanto ao capital registrado no Banco do Brasil (66,6 milhões de dólares em 1975), encontramos a referida empresa bem à frente de seus concorrentes estrangeiros e nacionais. Essa posição se evidencia no mercado nacional de produtos alimentícios: em todos os ramos em que o grupo penetrou, desempenha a função de forte oligopólio, ou mesmo, de controle monopólico absoluto.

Em 1979, a Nestlé controlava, no setor de laticínios, $75 \%$ do mercado de leite em pó, quase $100 \%$ do mercado de leite modificado para uso infantil, $95 \%$ do de creme de leite esterilizado e de leite condensado e $25 \%$ do de iogurte. Quanto aos outros produtos alimentícios, sua participação era a seguinte: café solúvel, $85 \%$; alimentos infantis, 65\%; bebidas

\footnotetext{
${ }^{9}$ A rentabilidade é a razão do lucro disponível sobre o patrimônio líquido.
}

achocolatadas, 64\%; sopas, 54\%; caldos, 38\%; chocolates, 30\%; farinhas, $25 \%$; sorvetes, $20 \%$; água mineral, $20 \%$; biscoitos, $5 \% .^{10}$

Para se ter, porém, uma ideia do poder de uma empresa desse tipo no Brasil, não bastam números, tais como o crescimento do capital ou a participação da empresa no mercado. Existem aspectos qualitativos que não se podem esquecer, um dos mais importantes dos quais, sem dúvida, é a relação da empresa com o Estado. Nesse contexto, é preciso mencionar, por exemplo, suas tentativas de se beneficiar de incentivos fiscais ${ }^{11}$ e sua penetração na burocracia de padronização que dita as normas para a produção de alimentos no Brasil.

Dependendo do Ministério da Saúde, a Comissão Nacional de Normas e Padrões para Alimentos (CNNPA) é constituída por representantes do setor público e do setor privado. Entre os três representantes do último, um membro é indicado pela Associação Brasileira de Indústrias de Alimentos (AMA), associação que agrupa os grandes oligopólios da área da alimentação. Na época a que se refere esta pesquisa (a década de 1970), o representante da ABIA na CNNPA era um alto funcionário da Nestlé brasileira. É inútil enfatizar o uso que pode ser feito desse cargo para favorecer, de maneira indireta, os interesses da empresa.

Dependendo da CNNPA, foram criadas subcomissões para padronizar a produção dos diversos ramos da indústria alimentícia. $\mathrm{Na}$ subcomissão encarregada dos laticínios, encontrávamos, mais uma vez, um representante da empresa suíça.

\subsection{Estrutura financeira do grupo suíço no Brasil}

Nada mais difícil do que descrever a estrutura de uma empresa transnacional do tamanho da Nestlé. No organograma das pp. 112-113, pode-se ver que a empresa se compõe de dois holdings, um suíço e um

${ }^{10}$ Exame, 26 de setembro de 1979

${ }_{11}$ Para o ano de 1974, por exemplo, os investimentos da Nestlé que se beneficiaram de incentivos fiscais foram os seguintes: 3,94 milhões de cruzeiros, na área da Sudene; 2,5milhões de cruzeiros, com incentivos do IBDF; 1,5milhão de cruzeiros, na área da Sudam; 1milhão de cruzeiros, com incentivos da Sudepe; 1milhão de cruzeiros, com incentivos da Embratur. 
panamenho, este último tratando dos investimentos na América Latina e na Ásia. Esses dois holdings controlam 14 companhias financeiras que operam no Brasil, das quais 13 a $100 \%$ e uma com urna participação acionária importante (a Gesparai, com 49\%).

Essas companhias controlam uma série de empresas, várias das quais não se ligam diretamente à produção alimentícia. A primeira é a Bob's Comestíveis, com controle acionário de $100 \%$ da Libby, McNeill \& Libby, controlada, por sua vez, pelo grupo suíço. Trata-se de uma cadeia de restaurantes e lanchonetes espalhados pelas grandes cidades brasileiras, e parece ser a única entrada da empresa no campo dos restaurantes.

A segunda empresa não-alimentícia associada ao grupo estudado é a Gebr. Sulzer A.G., segunda empresa suíça de fabricação de equipamentos pesados em geral. Entre suas subsidiárias no mundo inteiro, há quatro no Brasil, uma das quais controlada por um dos mais importantes complexos europeus no setor da metalurgia e da construção mecânica: o grupo Schneider de Paris. Das restantes, duas têm participação acionária da Nestlé a 50\%: a Sulzer do Brasil S.A. Indústria e Comércio e a Sulzer Weise S.A. Indústria e Comércio de Bombas Hidráulicas.

A terceira empresa não-alimentícia em que o grupo estudado tem participação no Brasil é a Ciba-Geigy, segunda empresa suíça em termos de vendas (logo depois da Nestlé) e maior grupo químico daquele país. Tem três filiais no Brasil, com uma participação minoritária da Nestlé $(11,5 \%)$ na mais importante, a Ciba-Geigy Química S.A.

Através do grupo francês de cosméticos e perfumes L'Oréal, a Nestlé participa, também, do controle da Procosa - Produtos Cosméticos, sétima firma brasileira de perfumaria em 1977.

Encontramos também a Nestlé, a Ciba-Geigy, a Gebr. Sulzer e o banco ligado a essas empresas, o Handelsbank Zurich, na "Adela Investment Company", poderoso holding de investimentos internacionais, cujas ações são distribuídas entre mais de 200 firmas industriais, bancos e instituições financeiras do mundo inteiro. Esse holding tem inúmeras participações no Brasil, em empresas que vão desde assessoria financeira até a produção de porcelana, passando por computadores, frigoríficos, indústrias químicas, containers, papel, seguros, avicultura, restaurantes, mineração, safaritours etc.

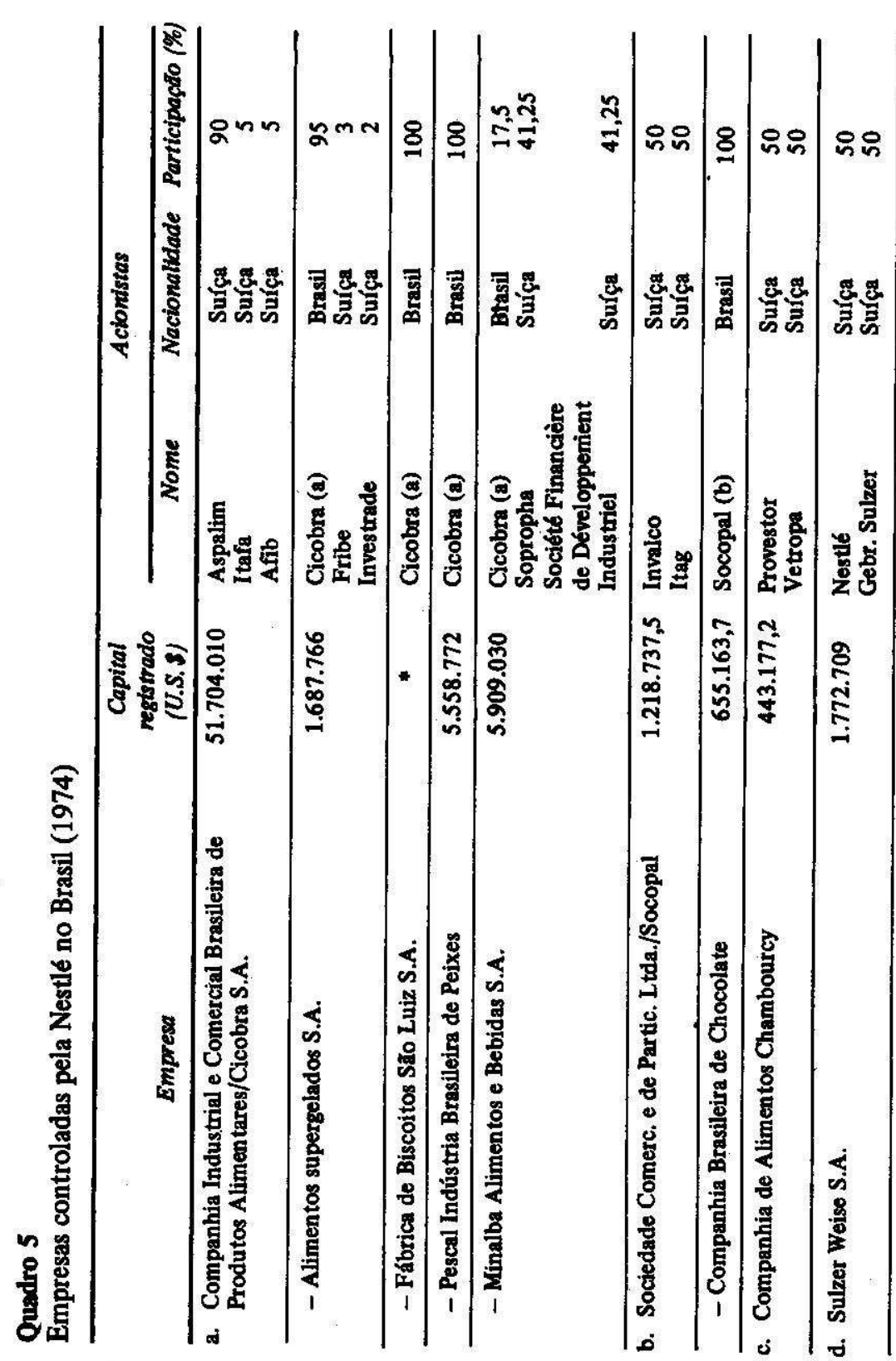

121 
A estratégia da Nestlé no Brasil se encaminha para uma diversificação e uma concentração cada vez maior. Sua participação em empresas não-

alimentícias é recente e data principalmente da década de 1970. Ao

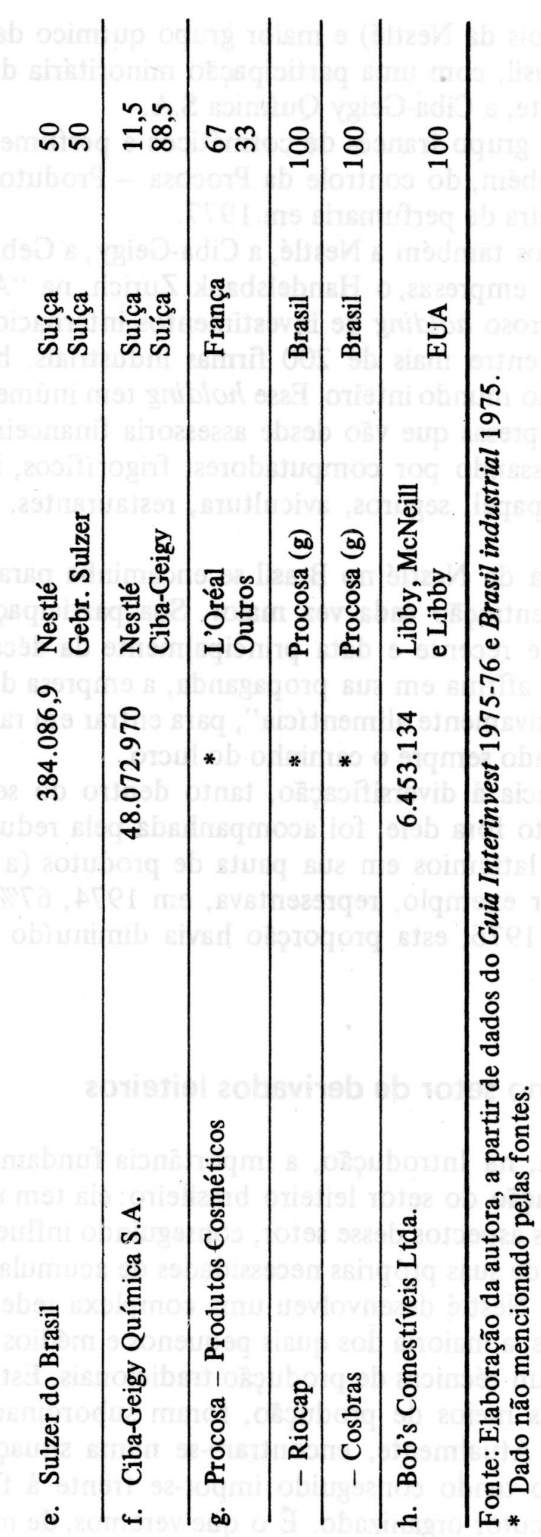

contrário do que afirma em sua propaganda, a empresa deixou de ter uma produção "exclusivamente alimentícia", para entrar em ramos novos e prometedores, seguindo sempre o caminho do lucro.

Sua tendência à diversificação, tanto dentro do setor da produção alimentícia quanto fora dele, foi acompanhada pela redução constante da importância dos laticínios em sua pauta de produtos (a participação dos leites em pó, por exemplo, representava, em 1974, 67\% do faturamento da empresa; em 1976, esta proporção havia diminuído para 56\%, e, em 1979, para 52\%).

\subsection{A Nestlé no setor de derivados leiteiros}

Já se mencionou, na Introdução, a importância fundamental da empresa suíça na organização do setor leiteiro brasileiro: ela tem um poder de controle sobre vastos aspectos desse setor, conseguindo influenciá-lo como um todo, em função de suas próprias necessidades de acumulação.

Primeiro, a Nestlé desenvolveu uma complexa rede de relações com seus fornecedores, a maioria dos quais pequenos e médios produtores familiares, que utilizam técnicas de produção tradicionais. Estes, apesar de proprietários de seus meios de produção, foram subordinados à empresa de várias maneiras. Atualmente, encontram-se numa situação de acentuada dependência, não tendo conseguido impor-se frente à firma compradora como um interlocutor organizado. É o que veremos, de maneira mais detalhada, no capítulo seguinte.

Foi mencionado, também, o domínio da empresa no setor da indústria de derivados leiteiros.

Qual é a evolução recente desse setor como um todo? Trata-se, claramente, de um setor muito concentrado: segundo o Censo de 1970, os 
19 maiores, estabelecimentos são responsáveis por $57 \%$ do valor da produção e $67 \%$ do valor da transformação industrial. ${ }^{12}$

Quanto à evolução do setor durante os últimos anos, existem algumas indicações de uma forte tendência à concentração: o número de fábricas de laticínios inspecionadas pelo Ministério da Agricultura, por exemplo, diminuiu, entre 1970 e 1977, em 21\%. De outro lado, entre os investimentos do setor de laticínios beneficiados por incentivos fiscais do Conselho de Desenvolvimento Industrial (cm) entre 1969 e 1975,62\% do valor dos investimentos foram feitos por apenas cinco empresas. ${ }^{13}$

Há um rápido processo de aquisição de pequenas empresas de laticínios pelas grandes, que tentam, assim, reagir contra o déficit que apresenta seu suprimento de leite cru. As pequenas, por sua vez, estão enfrentando sérios problemas, causados pelas exigências sanitárias do Serviço de Inspeção Federal e pelas medidas fiscais que dificultaram a estocagem de matéria-prima durante a época de safra.

Nesse quadro de uma concentração cada vez maior do setor, a posição predominante da Nestlé se afïmou há mais de meio século. Sua participação no setor de produção e de transformação do leite lhe permite controlar o destino de importante parte da produção nacional.

Em lugar de contribuir para a solução dos problemas criados pelo déficit de abastecimento leiteiro nas metrópoles, o grupo transnacional está tornando-os cada vez mais críticos. Diversificando sua produção e destinando-a a camadas limitadas da população, está desviando uma parte considerável da produção nacional de leite para a industrialização, de derivados sofisticados e supérfluos.

Nos momentos mais críticos do abastecimento, o Ministério da Agricultura tenta compensar a escassez de leite fluido dos grandes centros consumidores, recorrendo à importação de leite em pó. Essas importações podem ser procedentes da matriz ou de outras filiais da Nestlé.

${ }^{12}$ E não foi considerado, para esse cálculo, o maior estabelecimento, por falta de informações. Os dados também não precisam quantos desses estabelecimentos pertencem a empresas comuns. [Tabelação especial do Censo Industrial de 1970, citada em Pires e Bielchowsky, 1977, p.39]

${ }^{13}$ Tabelação especial do Censo Industrial de 1970, citada em Pires e Bielchowsky, 1977, p.39.
A empresa, responsável, em parte, pela escassez do leite in natura no Brasil, sempre negou energicamente tais fatos, alegando não ter fábricas nos países que exportam leite para o Brasil. ${ }^{14}$

Contudo, encontram-se quatro fábricas da Nestlé numa lista oficial de empresas argentinas creditadas para exportar leite em pó para o Brasil. ${ }^{15}$ Os outros países de onde o leite em pó está sendo importado são a Nova Zelândia, a Polônia, a Irlanda e os países do Mercado Comum Europeu. A empresa tem fábricas de laticínios na maioria dos países da Comunidade Econômica Europeia e na Nova Zelândia. Está também presente na Irlanda, mas não parece dedicar-se, ali, à produção de leite em pó. ${ }^{16}$

A insistência da empresa em negar totalmente sua presença nesses países só pode ser uma indicação de que não quer que sejam aprofundadas as relações comerciais entre suas filiais.

O Jornal do Brasil de 5 de junho de 1973 afirmou, com base em informações oficiais, que a quota de importações de leite em pó da Nestlé poderia chegar a 4 mil toneladas, ou seja, a $7 \%$ das importações totais efetuadas naquele ano. Pode ser útil acrescentar aqui que o preço do quilo do leite em pó vendido pela empresa no mercado interno é bem mais alto que o preço do leite em pó no mercado internacional.

É típico o desvio, já mencionado, de grande parte do leite produzido no país, para a produção de derivados sofisticados, "mágicos", dirigidos à "nova mulher brasileira". Para disseminar esses produtos, a empresa teve de investir maciçamente em publicidade. A esse respeito, convém citar a opinião do Diretor Comercial da Cicobra sobre a venda de café solúvel (que vale, também, para os laticínios mencionados aqui): "Vender [Nescafé] é marketing puro; devemos criar o hábito do solúvel nos lares brasileiros". ${ }^{17}$

\footnotetext{
${ }^{14}$ Nestlé rebate as críticas e acusa distribuidora", in Folha de Sdo Paulo, 7 de abril de 1977.

15 As importações foram autorizadas para a S.A. Nestlé Argentina de Productos Alimenticios, das províncias de Santa Fe, Córdoba, Entre-Rios e Buenos Aires (Dados DIPOA, 1977).

${ }^{16}$ Rastoin, [s/d] e 1976

${ }^{17}$ Exame, 26 de setembro de 1979.
} 


\section{A empresa e seus fornecedores de leite}

A Nestlé é uma das maiores empresas alimentícias brasileiras, em termos do número de produtores rurais a ela subordinados: no Brasil, mais de 40 mil produtores dependem de suas compras, somente no caso do leite. A empresa já foi citada por Kautsky, no fim do século passado, como exemplo típico da dominação do capital sobre formas de produção camponesa. ${ }^{1}$ Ver-se-á, aqui, quais são as razões pelas quais uma empresa desse tipo escolheu não se encarregar ela mesma da produção de sua principal matéria-prima, e como se adaptou às condições do campo brasileiro.

\subsection{Algumas reflexões sobre a persistência da produção familiar no} campo

A tendência à concentração da propriedade foi vista, durante muito tempo, como única saída possível para a agricultura. O próprio Marx achava que as pequenas unidades de produção tradicionais não seriam capazes de concorrer, a longo prazo, com grandes estabelecimentos capitalistas, transpondo, assim, para a agricultura, o esquema da concentração industrial do século XIX.

Um século mais tarde, no entanto, a pequena exploração familiar ainda não foi eliminada, nem nos países de industrialização mais antiga, nem em sociedades periféricas: continua existindo, apesar da modernização do campo e da possível concorrência de estabelecimentos capitalistas com alto grau de concentração e uso de trabalho assalariado.

Em artigo recente, Servolin resumiu as vantagens que favorecem a pequena exploração familiar e explicam sua permanência, impedindo sua transformação em empresas capitalistas. Ele destacou três razões para explicar esse fenômeno.

A primeira é relacionada à especificidade do processo de trabalho agrícola: suas características não permitem uma divisão do trabalho muito desenvolvida nos vários estágios da produção. Estes não podem ser

\footnotetext{
${ }^{1}$ Kaustsky, 1977, v. II, p.144
}

realizados de maneira conjunta, porque são submetidos ao próprio ritmo biológico da natureza. A parte principal do processo de produção é desenvolvida pelas células vegetais ou animais, e escapa, pois, à decomposição analítica que permitiu a passagem, no processo de produção industrial, para a manufatura e, depois, para a indústria capitalista.

Em vista do atual estágio de desenvolvimento tecnológico referente à produção agrícola, a divisão do trabalho não é compensadora e ganhos de escala representam poucas vantagens (com algumas exceções, tal como na produção avícola). A pequena exploração familiar pode, portanto, assumir a produção de vários produtos, sem ser desqualificada pela concorrência capitalista.

O segundo ponto levantado por Servolin retoma uma observação feita anteriormente por Marx: uma unidade de produção capitalista somente é rentável se alcançar a taxa de lucro médio vigente no resto da economia. No caso de uma pequena exploração familiar, ao contrário, o objetivo não é a valorização do capital investido, nem a obtenção de lucro, mas a reprodução de seus meios de produção e a subsistência da comunidade familiar. $\mathrm{O}$ produtor familiar pode renunciar à renda da terra, ao lucro e à amortização de seu capital, pode até renunciar a um salário correspondente ao pago pela indústria, e se satisfazer unicamente com a possibilidade de sua reprodução simples.

Na agricultura, portanto, a empresa capitalista parece não apresentar vantagens significativas no plano técnico e ser mais vulnerável, no plano econômico, que a unidade familiar tradicional.

O terceiro argumento levantado por Servolin para explicar a permanência dessa forma de produção pré-capitalista é a instituição da propriedade privada da terra; a compra de terra significa a mobilização de um capital totalmente improdutivo, o que pouco interessa a empresas capitalistas que procuram uma rápida circulação de dinheiro. Ou, como diz Alberto Passos Guimarães, “o investimento dedicado à compra da terra (...), ou ao pagamento da renda da terra arrendada, desvia do produtor capitais que, se aplicados na produção, não só reduziriam seus custos como possibilitariam sua expansão. Desse modo, o investimento desviado da produção atua como um limite à acumulação de capitais" (Guimarães, 1979, p. 151). 
Isso significa que, ao lado do desenvolvimento de uma agricultura tipicamente capitalista, a pequena produção tradicional continua reproduzindo-se. As duas formas de produção passaram a coexistir, especializando-se em produtos específicos, em formações sociais ou em momentos históricos diferentes.

2.2 Apropriação do sobretrabalho camponês pelo capital e estratégias das grandes empresas alimentícias

Não é durante o processo de produção propriamente dito que o capital se apropria do sobretrabalho camponês: é no processo de circulação dos produtos agrícolas (Faure, 1977). Enquanto estamos na esfera da produção agrícola tradicional, não distinguimos capitalista, proprietário fundiário ou proletário; há somente um produtor. Mas, quando esse produtor vende suas mercadorias a um preço mais baixo que seu valor o que só garante a reprodução de sua força de trabalho - está transferindo um excedente para o capital comercial ou industrial com que trata. Isso explica por que o modo de produção dominante capitalista integrou e subordinou, dessa maneira, elementos pré-capitalistas, apesar de que estes últimos podem significar, em outros aspectos, limites para a acumulação de capital, no conjunto da economia.

A indústria de transformação, no entanto, não pode ser considerada como um setor autônomo, beneficiário exclusivo da captação do excedente agrícola. Num sistema de economia concorrencial, o alcance de um lucro particularmente alto atrairia novas empresas para esse setor, o que automaticamente faria declinar a taxa de lucro.

O excedente agrícola somente poderá ser realizado pela indústria de transformação se esta possuir um controle monopólico de seu mercado, caso em que o sobrelucro poderá ser muito importante. Mas, nesse caso, ainda deverá resistir às pressões das classes dominantes, em sua luta pelo controle dos preços alimentícios. Este permite uma reprodução mais barata da força de trabalho e uma transferência do excedente agrícola para o resto da economia (Hairy, 1973), o que beneficia, em última instância, o capital em seu conjunto.
Que caminhos restaram ao grande capital concentrado para obter um sobrelucro na esfera alimentícia? Depois de seus esforços para conseguir o controle monopólico dos mercados de alimentos industrializados de grande difusão, começou a expandir-se em áreas novas, menos controladas pelo poder público. Passou a produzir alimentos sofisticados, de forte valor agregado, destinados prioritariamente às camadas de maior poder_ aquisitivo. Essa introdução e difusão crescente de alimentos "rentáveis" no mercado, além das mencionadas mudanças no padrão nutricional popular, leva, também, a um encarecimento gradual da alimentação no Brasil. Isso sem contar com os altos custos de marketing, publicidade, embrulhos sofisticados e atraentes etc., aos quais as grandes empresas alimentícias recorrem sistematicamente.

\subsection{Capital transnacional e produção agropecuária}

Os aspectos que garantiram a sobrevivência da pequena exploração familiar dentro de formações sociais predominantemente capitalistas são os mesmos que tornaram a produção direta pouco atraente para o grande capital transnacional: a especificidade do processo de trabalho agrícola, a concorrência com explorações familiares que não dependem do alcance de lucros e a necessária imobilização de um capital destinado à compra da terra. Todos esses aspectos restringiram a participação direta do capital transnacional na agricultura.

O setor de produção de leite, por exemplo, é particularmente adaptado a um esquema produtivo de pequenas unidades. A constituição de grandes estabelecimentos cooperativos ou estatais, na URSS e nos países de sua influência, levou-os a fracassos, tanto do ponto de vista técnico quanto financeiro: o tamanho "ideal" de uma exploração leiteira corresponde ao número máximo de animais de que um produtor pode cuidar (com eventual ajuda, para certos trabalhos periódicos). Ultrapassando esse limite, funcionará como simples justaposição de processos de trabalho individuais. Estudos específicos demonstraram que, nesse caso, a produtividade por animal não apresenta melhorias ou até mesmo diminui, o que não justifica investimentos suplementares para conseguir ganhos de escala (Servolin, 1979). 
O fato de não se dedicar à produção agropecuária direta permite também escapar aos riscos dessa atividade tão aleatória. O leite, por exemplo, apresenta uma produção muito irregular (excesso na época de chuvas, falta na entressafra). As empresas compradoras, motivadas por causas financeiras, podem decidir uma redução de seus estoques de laticínios durante a época de safra, e recusar-se a comprar leite de seus fornecedores: nesse caso, são estes que assumem o risco de sua produção e têm de arcar com os problemas enfrentados pelas empresas transformadoras no mercado.

Uma outra razão para não entrar na produção agropecuária propriamente dita já foi citada anteriormente: a compra de matéria-prima "barata", quando reforçada por uma posição de monopólio, pode garantir às empresas transformadoras a realização do excedente proveniente da agricultura. $^{2}$

As vantagens enumeradas, no entanto, não são estáticas, nem absolutas: em certas circunstâncias, a produção direta apresenta atrativos bastante fortes para compensar os problemas que provoca. No Brasil, por exemplo, incentivos fiscais e preocupações especulativas atraíram, para a agricultura, corporações transnacionais que nunca se tinham dedicado a esse tipo de atividade. De outro lado, os progressos da tecnologia agrícola podem mudar o quadro atual, que favorece as pequenas explorações.

Atualmente, é uma constante na política da Nestlé, por exemplo, nunca entrar na produção direta de leite (nem de cacau, café, açúcar ou outras matérias-primas de que precisa).

Para que pudesse funcionar economicamente, no entanto, contando com um abastecimento regular de matéria-prima de boa qualidade, foi preciso desenvolver mecanismos próprios de controle da produção, induzindo os produtores a utilizarem as técnicas que mais beneficiam a empresa. Isso implica um delicado jogo de equilíbrio entre modernização e conservação de técnicas produtivas tradicionais.

${ }^{2}$ Ao lado desses fatores, que, sem dúvida, são essenciais, temos de lembrar também o elemento político: a posição de uma empresa estrangeira que não possui rebanho, plantações, nem terras, mas se encarrega unicamente da transformação de produtos agropecuários, escapa mais facilmente às ameaças de eventuais correntes nacionalistas, dirigidas contra empreendimentos de capital transnacional no setor de produtos alimentícios básicos.
De um lado, é preciso aumentar a produção de leite, para aproveitar a economia de escala da fábrica e ampliar o lucro da empresa. De outro lado, esse aumento da produção não pode depender demais da aquisição, pelo produtor, de insumos modernos, que elevarão seus custos e, consequentemente, o preço de venda de sua matéria-prima: o volume disponível deve crescer, mas seu preço deve ser o mais baixo possível!

Aqui ressalta a importância de um serviço de assistência técnica, que faz a ligação entre a empresa e seus produtores, induzindo estes últimos a produzirem mais leite, sem aumentar demais seus custos.

\subsection{Implantação e consolidação das fábricas de leite Nestlé}

A localização dessas fábricas de leite no Brasil corresponde à evolução constatada em outros países da América Latina, onde o grupo suíço está implantado há várias décadas ${ }^{3}$ : sua instalação começou em locais relativamente próximos aos maiores centros urbanos, e foi-se afastando cada vez mais para regiões menos industrializadas.

No Brasil, suas primeiras fábricas de laticínios foram implantadas na proximidade das cidades de São Paulo, Rio de Janeiro e, mais tarde, Belo Horizonte. As fábricas da década de 1960 já se encontram mais afastadas desses centros, no interior mais longínquo dos Estados de São Paulo, Rio e Minas Gerais. Durante a década de 1970, foram instaladas três fábricas de leite em pó: uma no Triângulo Mineiro, uma no Norte e uma no Nordeste do país.

Este último deslocamento não foi provocado única e exclusivamente pelo regime de incentivos fiscais que atrai investimentos industriais para essas regiões. Parece ser um meio da Nestlé evitar enfrentar a concorrência direta com outras empresas compradoras, e escapar, assim, à acusação de que seria responsável pela escassez do leite fluido no mercado. De outro lado, pode ser mais fácil, para a empresa, implantar fábricas em novas regiões do que lutar contra os fatores que contribuem para a descapitalização das unidades produtivas localizadas nas bacias leiteiras

${ }^{3}$ Nestlé, 1975 
tradicionais, tal como, por exemplo, o crescimento acelerado do preço da terra.

A empresa está sempre se deslocando, pois, para novas regiões (principalmente regiões de gado de corte), onde se instala como única compradora e começa a organizar novas bacias leiteiras. No Brasil, a localização dessas novas fábricas corresponde a mais uma vantagem: nas regiões escolhidas, a época de chuvas acontece exatamente na entressafra da bacia leiteira tradicional. Isso permitirá a produção máxima de leite em pó durante a época em que há maior falta desse produto no mercado.

Implantar uma fábrica de leite em pó numa região com pouca produção leiteira não é, porém, uma tarefa ao alcance de qualquer empresa. A Nestlé tem uma longa prática disso, e começa os contatos com seus futuros fornecedores até quatro anos antes de começar a construção da fábrica. Os técnicos de seu serviço de assistência aos produtores visitam as fazendas, convencem os fazendeiros a comercializarem o leite, que eventualmente já é subproduto de sua atividade, e lhes dão as informações necessárias para organizar (ou aperfeiçoar) sua produção. Assim, o fornecimento leiteiro já está assegurado no dia em que a nova fábrica começa a funcionar.

Segundo a própria empresa, o sucesso da implantação de suas fábricas depende de dois fatores básicos: a existência de uma eficiente equipe de assistência técnica e a organização de um bom sistema de recolhimento de leite. Esses dois fatores são essenciais ao desenvolvimento da produção leiteira das regiões escolhidas, mas constituem, também, as chaves da relação de subordinação criada entre a Nestlé e seus fornecedores.

\subsection{Assistência Nestlé aos produtores de leite}

O serviço de assistência técnica da empresa, a ANPL (Assistência Nestlé aos Produtores de Leite), foi criado em 1952 e contava, em 1976, com 107 técnicos responsáveis pela ligação entre a Nestlé e seus mais de 20 mil produtores não-associados a cooperativas. Segundo a empresa, esse serviço foi criado para resolver o problema da irregularidade do fornecimento e aumentar a produtividade, racionalizando a produção de seus fornecedores.

A ANPL apoia suas atividades técnicas em alguns pontos básicos. O primeiro é a necessidade de uma alimentação adequada para o gado, produzida, na medida do possível, na própria fazenda, para permitir uma economia de razões concentradas: a equipe técnica ajuda na formação de pastagens e de capineiras, e incentiva muito a introdução de silagem nas fazendas. Outra atividade essencial é sua ajuda na profilaxia do rebanho e na higiene da produção: seus técnicos ensinam, por exemplo, como aplicar vacinas e pulverizar o gado contra ectoparasitas, facilitando a aquisição dos remédios e equipamentos necessários.

A empresa participa ainda, ativamente, da melhoria progressiva do rebanho: mantém granjas experimentais, onde cria reprodutores de linhagem, para serem vendidos aos fornecedores pelo preço de custo, em prestações mensais retidas do pagamento do leite fornecido. Essa assistência financeira não se restringe à venda de bezerros pela empresa, mas atinge também a aquisição de insumos, a construção de silos ou estábulos etc. Raramente se trata de montantes muito elevados, mas, mesmo para quantias reduzidas e prazos de alguns meses, cria laços de forte dependência entre os produtores e a empresa.

Esse trabalho de assistência é baseado em pesquisas de campo regulares, que fazem um levantamento das técnicas produtivas utilizadas pelos produtores e da estratégia a ser seguida pela ANPL. No quadro 6, temos um apanhado das atividades deste órgão entre os produtores, de 1972 a 1976.

Fica claro, no quadro a seguir, o grande incentivo fornecido pela ANPL à formação de capineiras e de silos nas propriedades dos seus fornecedores. A tonelagem dos novos silos construídos com a ajuda da Nestlé se elevou a uma taxa média anual de $71 \%{ }^{4}$ Por outro lado, os financiamentos de equipamentos e máquinas parecem estar se tornando cada vez mais secundários.

\footnotetext{
${ }^{4}$ Comparando o número de silos com o das fazendas onde estão localizados, notamos que se trata, principalmente, de construções em fazendas que já possuem silos, e que são, portanto, estabelecimentos maiores.
} 
A empresa incentiva a compra de remédios e sementes pelos seus fornecedores de duas maneiras: ou comprando esses insumos em grande quantidade, para revendê-los, ou, então, facilitando sua aquisição direta, através de financiamentos. A ANPL também busca divulgar novas técnicas de seu interesse, através de reuniões de produtores de leite e publicação de folhetos e histórias em quadrinhos, redigidos em linguagem simples. Colabora, também, com organismos oficiais de assistência técnica, e mantém convênios com Escolas de Veterinária e com o Instituto de Zootecnia, da Secretaria de Agricultura de São Paulo.

\section{Quadro 6}

Atividades do serviço de assistência técnica da Nestlé

entre os produtores de leite (1972-76)

\begin{tabular}{lrrrr}
\hline & $1972-73$ & $1973-74$ & $1974-75$ & $1975-76$ \\
\hline Técnicos & 65 & 84 & 89 & 107 \\
Visitas de assistência técnica & 17.138 & 19.397 & 24.649 & 27.687 \\
Reuniões promovidas & 408 & 496 & 624 & 692 \\
Participantes & 4.855 & 6.514 & 7.859 & 7.936 \\
Construção de silos* & 513 & 918 & 980 & 1.808 \\
Tonelagem dos silos & 20.353 & 34.717 & 42.934 & 93.944 \\
Fazendas com silos & 2.612 & 3.200 & 3.236 & 4.004 \\
\% do total de propriedades & 15,9 & 18,3 & 16,4 & 20,4 \\
Formação dẹ capineiras (ha)* & 4.554 & 6.653 & 7.136 & 9.404 \\
Construção de estábulos* & 283 & 387 & 387 & 466 \\
Represas construídas* & 196 & 210 & 522 & 592 \\
Reprodutores bovinos & & & & \\
$\quad$ fornecidos* & 318 & 309 & 368 & 326 \\
Equipamentos e máquinas* & 446 & 496 & 442 & 365 \\
Arame farpado fornecido & & & & \\
(metros)* & 1.699 .300 & 1.358 .814 & 916.550 & 2.499 .250 \\
\hline
\end{tabular}

Fonte: Folheto Nestlé.

* Através de adiantamento em dinheiro pela ANPL.

As informações anteriores podem ser lidas em qualquer artigo de propaganda da Nestlé. A imagem que quer difundir sobre o trabalho de seus serviços de assistência é essencialmente técnica, e privilegia sempre sua colaboração para o aumento da produção. A função da ANPL, no entanto, é bem mais vasta que isso, e abrange mecanismos que a empresa desenvolveu para tentar subordinar os produtores.

O que interessa saber, no caso, é como funciona concretamente esse sistema de assistência técnica. Está organizado em torno de algumas fazendas prioritárias, que servem de foco de irradiação das técnicas a serem implantadas. ${ }^{5}$ A escolha das fazendas prioritárias é feita em função de uma pesquisa prévia sobre quem são as lideranças da região. Essas lideranças são constituídas, na maioria dos casos, de grandes produtores, mas podem, também, ser formadas de produtores médios ou pequenos que irão crescendo. São escolhidas por sua influência entre a população local é receberão o privilégio de uma assistência bem mais intensiva e de uma prioridade absoluta no trabalho dos técnicos (enquanto, muitas vezes, pequenos produtores isolados e de produção insignificante nunca viram os técnicos da empresa, em 27 anos de existência da ANPL).

O favorecimento das lideranças entre seus produtores de leite é importante para a difusão das novas técnicas de produção: os fazendeiros comumente são mais influenciáveis pelo que acaba de ser implantado na fazenda do "vizinho rico e bem-sucedido", do que pelos conselhos de técnicos que não arcam com os riscos da produção. De outro lado, é importante que a empresa possa contar com a simpatia dessas lideranças, para não ser ameaçada por elas na hora em que surgem novos concorrentes na região, em busca de leite cru. Como raramente um produtor muda de comprador sozinho (ele faz parte de uma corrente ou "linha de leite"), deverá convencer vários produtores da linha a mudar com ele, para que o transporte do leite até a nova usina seja mais "rentável". É evidente que, nesse esquema, interessa muito à Nestlé que as lideranças tenham estreitos laços de dependência em relação a ela, laços criados pelo medo de perder os benefícios de uma assistência técnica prioritária.

Com essa política de favorecimento de alguns fornecedores mais dinâmicos, o grupo transnacional participa, ativamente, do processo capitalista de diferenciação dos produtores: um número restrito, escolhido, pela empresa, por suas características pessoais de liderança e por suas possibilidades de capitalização, é incentivado prioritariamente a aumentar

\footnotetext{
${ }^{5}$ Assistência Nestlé aos Produtores de Leite, 1968.
} 
sua produção e sua renda, enquanto a grande maioria dos produtores é relegada a um segundo plano e recebe somente uma assistência episódica. ${ }^{6}$

A Nestlé, graças a seu serviço de ajuda técnica e à sua constante demanda de leite, que dá ao produtor a certeza de sempre conseguir vender seu produto, incentivou um aumento espetacular da produção nas regiões em que se instalou. Em Araras (SP), por exemplo, onde foi implantada sua primeira fábrica no país, de uma pequena produção inicial de 2 mil toneladas de leite fresco, em 1921, passou-se a industrializar $700 \mathrm{mil}$ toneladas, em 1975. Não se pode afirmar que tal crescimento se deva exclusivamente à presença da Nestlé na região, mas seu papel foi, sem dúvida, importante.

É inegável que o grupo suíço conseguiu aumentar a produção das regiões em que atua, mas já vimos, também, que esse crescimento nem sempre corresponde a um aumento proporcional da renda dos produtores. De outro lado, em certos momentos, a empresa está mais interessada em diminuir seu recebimento que em aumentá-lo. O que faz, nesse caso? Manda seus técnicos para o campo, aconselhando os produtores a diminuírem a administração de ração, porque suas vacas precisam descansar, e provoca, assim, um decréscimo da produção de leite. Ou, como disse um produtor ligado à empresa: "O papel do técnico é convencer o fazendeiro de que o que é vantagem para a companhia também é vantagem para ele".

Para conseguir influenciar os fornecedores dessa maneira, é necessário que estes sintam certa confiança no técnico da empresa. Isso explica a importância dada pela Nestlé (e realçaria em suas publicações) ao "bate-papo" que o técnico terá, com os produtores, sobre o tempo, a colheita etc. Esse "bate-papo" informal é, ainda, essencial para informar a empresa sobre as dificuldades ou os projetos de seus fornecedores.

A ANPL desempenha um papel importante na relação entre a empresa e seus fornecedores, mas esse papel também não pode ser superestimado: os produtores não escolhem vender seu leite para a Nestlé por causa de seu serviço de assistência técnica, mas, sim, porque é "boa

\footnotetext{
${ }^{6}$ Não podemos, no entanto, deixar de lado, aqui, outro aspecto dessa assistência técnica: a que está sendo levada aos produtores, através de reuniões e publicações especializadas, e que conta com um público mais amplo.
}

compradora" (ver mais para a frente). Além disso, tem-se notado, durante os últimos anos, que a empresa está desativando a ANPL em suas regiões de implantação antiga: ela não parece mais preencher uma função essencial, quando o fornecimento de leite é considerado satisfatório.

\subsection{Linhas de leite}

O segundo fator importante para o desenvolvimento da produção leiteira, na região de implantação de uma nova fábrica, é a organização de uma eficiente rede de recolhimento do leite. Quem organiza as linhas de leite e decide a respeito do itinerário e do horário é a empresa transformadora. Mas quem paga o transporte, da fazenda até o posto de recebimento e do posto de recebimento até a fábrica, são os produtores. Eles pagam à empresa um preço fixo de alguns centavos por litro de leite transportado, e esta paga, por sua vez, ao carreteiro, em função da quilometragem rodada. Essas duas quantias podem não ser iguais, sendo que, nesse caso, quem normalmente leva vantagem é a empresa.

Não deve ser essa vantagem financeira, no entanto, que motiva a Nestlé a controlar, a todo custo, a rede de transporte, mesmo em bacias leiteiras organizadas há décadas: é que isso lhe permite pressionar melhor os produtores, quando necessário. Se um grande produtor da linha, por exemplo, decide vender seu leite, de agora em diante, para um concorrente que lhe oferece um preço mais alto, a empresa pode ameaçar os fornecedores restantes de fortes acréscimos nos custos operacionais, ou de, simplesmente, abandonar a linha, esperando, assim, que eles consigam evitar a desistência. Em época de excesso de leite, ao contrário, e quando segue uma política de diminuir seu recebimento diário, pode simplesmente fechar uma linha, declarando-a "menos rentável".

\footnotetext{
${ }^{7} \mathrm{Na}$ época da pesquisa de campo realizada na cidade mineira de Três Corações, estava acontecendo o seguinte conflito: os produtores de uma linha haviam descoberto que seu carreteiro recebia somente $60 \%$ da quantia paga mensalmente por eles ao grupo suíço para tal fim. Como ele se queixasse de receber um salário insuficiente e a Nestlé se recusasse a aumentá-lo, o grupo de produtores decidiu contratá-lo de maneira direta, sem utilizar mais a empresa como intermediária. Esta reagiu, exercendo fortes pressões sobre os produtores, para que desistissem do plano, e acabou autorizando o aumento salarial, para que ele não se realizasse. 
Apesar de os fazendeiros pagarem a organização do transporte do leite, seu poder sobre ela é bastante reduzido.

Com o tempo, cada empresa compradora de leite estabeleceu, assim, seu "território", delimitado por suas linhas fixas de fornecimento. E esse território normalmente é respeitado por suas concorrentes: é somente em situações excepcionais que estas tentam expandir-se à custa de uma empresa de porte parecido, quebrando, desse modo, o acordo implícito vigente. Existem, no entanto, alguns territórios sobrepostos nas bacias leiteiras tradicionais, onde a luta pelo leite toma proporções mais sérias.

Já foram citadas, aqui, algumas técnicas de controle que podem diminuir a "independência" dos produtores em relação à Nestlé. Essas técnicas (assistência técnica e creditícia, controle de transporte) podem ser utilizadas pela empresa para pressionar seus produtores, nas ocasiões em que julga necessário. Não constituem, porém, mecanismos que controlem totalmente a produção leiteira regional, como seria no caso de a empresa assumir, ela própria, a produção, ou de desenvolver mecanismos de integração vertical.

\subsection{A Nestlé, os produtores e suas cooperativas}

As cooperativas de produtores de leite formam uma boa ilustração de alguns dos caminhos seguidos pelo movimento cooperativista dentre as possibilidades do atual modelo de desenvolvimento brasileiro.

As primeiras cooperativas leiteiras surgiram durante a década de 1930 no Estado de São Paulo, pela iniciativa de grandes e médios produtores. Eles tentaram organizar-se, a fim de responder à crescente demanda de alimentos para o mercado urbano. Como o leite é um produto altamente perecível, os produtores se encontravam numa situação de dependência muito grande em relação aos compradores, e sentiram, desde cedo, a necessidade de se unirem para comercializar seu produto, primeiro em cooperativas regionais e depois em cooperativas centrais.

Essa dependência dos produtores de leite é particularmente importante (eles não têm possibilidade de estocar seu produto para pressionar o setor de comercialização) e explica a rápida expansão do movimento cooperativista dentro do setor. Atualmente, cerca de 50\% dos produtores de leite brasileiros são filiados a uma cooperativa.

No que diz respeito a seu funcionamento e à sua autonomia de decisão, as cooperativas leiteiras regionais apresentam características bastante diversas: algumas entre elas funcionam de maneira independente, outras são filiadas a cooperativas centrais, outras ainda se ligaram a empresas de transformação de capital privado, entregando-lhes toda a produção de seus cooperados.

Os serviços prestados pelas cooperativas regionais aos produtores também não são uniformes, e dependem da própria cooperativa. Ao lado de um posto de recebimento de leite, esta poderá ter um armazém de abastecimento de insumos, um departamento de assistência técnica, um posto de inseminação artificial etc. Quanto às cooperativas centrais, elas também têm uma orientação própria na sua política leiteira. A Cooperativa Central do Estado de São Paulo, por exemplo, incentiva a produção de leite B, a Cooperativa Central do Paraná ressalta a necessidade de melhoria da qualidade do leite $\mathrm{C}$, enquanto a Cooperativa Central do Rio de Janeiro está especialmente preocupada com sua concentração e crescimento.

A evolução dessas cooperativas centrais é caracterizada por sua tentativa de melhorar, cada vez mais, sua capacidade competitiva, num comportamento que corresponde ao de qualquer empresa capitalista. Para sobreviver e crescer tiveram de se adaptar à estrutura econômica vigente como entidades empresariais: disputando o mercado com poderosas empresas estrangeiras, as cooperativas centrais começaram a produzir os mesmos produtos sofisticados que precisam de tecnologia importada e se lançaram em grandes projetos de propaganda e marketing. Nesse sentido, estão seguindo a tendência geral notada no setor leiteiro brasileiro como um todo, dedicando uma parte cada vez maior da matéria-prima recebida à produção de derivados de luxo. A participação do leite $\mathrm{C}$ na produção das cooperativas centrais filiadas à CBCL, por exemplo, caiu em um ano (de 1975 para 1976), de $64 \%$ para $57 \%$.

As cooperativas leiteiras centrais se beneficiam do mesmo fenômeno de captação de excedentes da produção que as outras empresas transformadoras, mas aqui a captação se faz em dois níveis: uma primeira 
vez, a nível dos produtores, e uma segunda vez, a nível das cooperativas regionais.

$\mathrm{Na}$ medida em que as cooperativas regionais se encarregam principalmente da entrega do leite in natura e em que as centrais (que dispõem de maior capacidade produtiva e financeira) cuidam da industrialização, somente estas últimas conseguem certa rentabilidade. É um modo que as centrais encontraram para reforçar o poder financeiro de que precisam, em sua concorrência com empresas de capital privado nacional e transnacional, transferindo os ônus de suas atividades para seus afiliados e retendo os lucros financeiros para si próprias.

Essa é a razão pela qual algumas cooperativas centrais apresentam balanços com resultados positivos, enquanto muitas regionais vivem em situação financeira precária. Muitas vezes, estas últimas são obrigadas a procurar recursos em outras atividades, tais como aluguel de carros ou venda de gasolina ${ }^{8}$ : são somente intermediárias no processo de captação de excedentes, repassando-os para as indústrias de derivados, ou seja, as cooperativas centrais.

De outro lado, algumas centrais já assumiram um comportamento de concorrência empresarial frente a suas próprias afiliadas: vendem-lhes insumos a preço de mercado, com lucro, ou chegam a abrir postos de recepção de leite nas áreas de influência de suas cooperativas regionais, quando isso lhes parece mais rentável.

Os conflitos entre centrais e regionais não podem ser vistos, no entanto, fora da situação de dependência mútua em que se encontram. A própria diretoria das centrais é escolhida por representantes de suas cooperativas afiliadas, e estas últimas possuem grande parte do capital das centrais. Muitas vezes, essa participação, compulsoriamente retida, chega até a ultrapassar o capital próprio de que as regionais dispõem para si. De outro lado, as cooperativas regionais precisam da organização centralizada das centrais, no que diz respeito ao transporte e à comercialização de sua produção. Dependem, pois, das centrais, através de vários mecanismos financeiros, econômicos e organizacionais.

\footnotetext{
8 “CADE investiga oito cooperativas de leite", in Jornal do Brasil, 27 de setembro de 1974.
}

Dentro desse quadro, não é de se estranhar que o cooperativismo leiteiro apresente um dos principais problemas do sistema associativo brasileiro em geral, o problema da não participação e da não identificação dos cooperados. Para eles, a cooperativa pode chegar a se assimilar a qualquer empresa comercializadora de leite: a palavra "cooperativa", tal como ela é usada por muitos produtores, serve para indicar a empresa para quem entregam suas matérias-primas, seja uma associação de produtores, seja uma empresa privada de capital nacional ou estrangeiro. Acontece frequentemente ouvir-se falar da Nestlé ou da Danone como de "cooperativas"! E de fato, não pode existir muita diferença, aos olhos dos produtores, entre os dois tipos de empresas: em muitos casos, as duas têm o mesmo comportamento, oferecem as mesmas vantagens etc. $\mathrm{Na}$ área leiteira, especialmente, é difícil falar em retorno financeiro aos cooperados, por causa da baixa rentabilidade do produto.

A necessidade de se adaptar às exigências de um mercado liderado por corporações de capital altamente concentrado e a consequente escolha, pelas cooperativas centrais, de um esquema fortemente empresarial, entra em choque com a difusão da ideologia cooperativista entre seus associados: se o fortalecimento do sistema de cooperativas se faz por sua transformação em empresas capitalistas cada vez mais concentradas, isso dificultará, necessariamente, a identificação do produtor com sua cooperativa e sua consequente participação associativa.

O controle do poder político, dentro das cooperativas locais, depende das diferentes características regionais e sociais: em algumas regiões leiteiras, a representação dos produtores é homogênea; em outras, os conflitos políticos dentro das cooperativas refletem a diversidade de suas condições de produção e de vida. Esses elementos devem ser levados em conta quando se tenta entender a situação de cada cooperativa específica.

Quais são, agora, as relações existentes entre as cooperativas regionais, tão diversas em vários aspectos, e as grandes empresas de laticínios de capital privado nacional ou estrangeiro?

Voltando ao exemplo da Nestlé, vemos que essas relações são complexas: em certos casos, são relações de concorrência para obtenção do leite cru; em outros, as cooperativas foram totalmente subordinadas à empresa. 
O fenômeno de subordinação das cooperativas às empresas privadas se desenvolveu particularmente na área do leite: muitas cooperativas leiteiras regionais se tornaram simples intermediárias entre a Nestlé, por exemplo, e seus produtores. $\mathrm{O}$ caso mais frequente é o das cooperativas que se encarregam do transporte do leite, recolhendo os frascos nas fazendas e entregando-os na fábrica. Outras vezes, as cooperativas também cuidam da venda de insumos, aconselhadas, nisso, pelo serviço de assistência técnica da empresa.

De um lado, essas cooperativas facilitam, sem dúvida, as relações entre a Nestlé e seus fornecedores, centralizando-as. De outro lado, porém, reforçam seu poder de barganha, em função da grande quantidade de leite de que dispõem. Podem utilizá-lo para conseguir certas vantagens por parte da empresa, mas essas pressões, pelo menos nas regiões de implantação antiga, onde a empresa não está mais interessada em expandir-se, ainda parecem surtir efeitos reduzidos.

Em certos casos, a subordinação das cooperativas à empresa é quase total. Na cidade de Três Corações, por exemplo, caso que analisaremos mais detalhadamente na parte a seguir, a cooperativa, cujos diretores têm uma estreita ligação com a Nestlé, tornou-se quase um departamento desta, fazendo serviços que mais nada têm a ver com sua função original. A cooperativa da cidade acabou servindo de departamento de contabilidade para a empresa: esta dá um cheque global para a cooperativa, que é encarregada de distribuir os pagamentos mensais a cada um dos produtores. Sua função quase que se limita a essa atividade.

Frente a essa evolução de um número crescente de cooperativas como órgãos subalternos das transnacionais, defrontam-se concepções contraditórias. A posição do Banco Nacional de Crédito às Cooperativas (BNCC) tenta frear esse fenômeno, não concedendo créditos às cooperativas subordinadas a empresas privadas; na área de laticínios, por outro lado, a Confederação Brasileira de Cooperativas Leiteiras considera isso como estimulante e "inteiramente normal num sistema onde as cooperativas têm a liberdade de fechar contratos com quem quiserem".

\footnotetext{
${ }^{9}$ Entrevista com o Presidente da CBCL, março de 1978.
}

\subsection{A empresa em Três Corações}

Para entender melhor a atuação da Nestlé em suas áreas de implantação, foi realizado um estudo de caso.

A primeira fábrica da empresa em Minas Gerais foi implantada em 1957, em Três Corações, pequena cidade de certa importância no Sul do Estado e conhecido centro de comercialização de gado. Nessa época, a região vivia basicamente de atividades agropecuárias, com destaque para a produção de café, leite e policultura alimentar. A cidade, estrategicamente localizada entre São Paulo, Rio de Janeiro e Belo Horizonte, já dispunha de vias de comunicação com esses centros consumidores e apresentava condições de clima e solo, muito favoráveis à expansão da pecuária leiteira existente.

Em 1958, um ano depois de sua implantação, a fábrica recebeu $6.300 \mathrm{t}$ de leite, de fornecedores localizados numa área de $985 \mathrm{~km}^{2}$. Em 1978, 20 anos mais tarde, a Nestlé de Três Corações dispunha de uma capacidade instalada de 360 mil litros por dia, e recebia leite de 1.589 produtores individuais e de um número ligeiramente maior de associados a quatro cooperativas regionais. ${ }^{10}$

Em sua área de recebimento, que abrange 36 municípios, não é a única compradora: convive com pequenas fábricas de queijo, algumas cooperativas regionais e dois laticínios de porte médio. No entanto, controla a parte mais importante da produção de leite $\mathrm{C}$ na região e nenhuma de suas concorrentes chega a ameaçá-la seriamente. ${ }^{11}$

\footnotetext{
${ }^{10}$ Alpinópolis, Lavras, Três Pontas e São Tiago.

${ }^{11}$ Esses municípios pertencem às microrregiões homogêneas $\mathrm{n}^{\circ} 191$ (quase inteira), 195 (parte oeste), 199 (parte noroeste), 198 (parte nordeste) e 190 (parte leste). Trata-se de Aguanil, Alpinópolis, Bom Sucesso, Camacho, Cambuquira, Campo Belo, Cana Verde, Candeias, Carmo da Cachoeira, Carme da Mata, Carmópolis de Minas, Coqueiral, Cristais, Ibituruna, ljaci, Ingaí, Itapecerica, Itumirim, Itutinga, Lambari, Lavras, Luminárias, Nepomuceno, Oliveira, Passa-Tempo, Perdões, Ribeirão Vermelho, Santana da Vargem, Santana do Jacaré, Santo Antônio do Amparo, São Bento Abade, São Francisco de Oliveira, São João Del Rei, São Tiago, São Tomé das Letras, Três Corações e Três Pontas. Suas maiores concorrentes locais são a Figuinha, em Oliveira, a Cacisa, em Campo Belo, e as Cooperativas de Lavras, Carmo da Cachoeira e Carmópolis. Sua área de atuação é delimitada pela presença da Anderson-Clayton a leste; da Vigor, a sudeste; da Vigor e da Danone, a sudoeste: da Parmalat, ao sul; e da Nestlé/Calciolandia, a noroeste.
} 
No que diz respeito às unidades produtivas, pode-se dizer, de um modo geral, que, nos estabelecimentos menores, a produção é dirigida principalmente para o autoconsumo, gerando pequenos excedentes comercializáveis, enquanto os estabelecimentos médios e grandes se dirigem prioritariamente ao mercado. A pecuária leiteira é uma atividade comum a todos os tamanhos de unidades agropecuárias, seja sob a forma de excedentes, seja sob a de mercadoria capitalista. Os produtores, no entanto, não se dedicam unicamente a esse tipo de produção: somente em alguns municípios da parte leste da área de recebimento, ela é uma atividade quase exclusiva. No restante, muitos produtores têm um rebanho misto (para leite e carne) e se dedicam, também, a amplas atividades agrícolas.

Em 1950, a produção de leite era pouco diferenciada: havia poucas diferenças de produtividade entre os vários municípios, sendo que os que apresentavam características ligeiramente mais avançadas encontravam-se espalhados por toda a área. Quando comparamos esses dados com os do Censo Agropecuário de 1970, destacam-se duas observações: primeiramente, os índices de maior produtividade, anteriormente mais espalhados, concentraram-se nos municípios centrais da área de recebimento da Nestlé, formando um eixo norte-sul que passa por Três Corações, Lavras e Santo Antônio do Amparo. Esse eixo, que corresponde ao centro de sua região de atuação, desenvolveu-se ao longo da principal estrada rodoviária que liga Belo Horizonte a São Paulo.

A segunda constatação concerne aos municípios de Três Corações e de seu posto de recebimento mais próximo, Lavras. Os dois, que apresentavam uma produtividade média em 1950, tornaram-se dois entre os quatro municípios com maior produtividade da região em 1970 (com 2,8 litros por dia e por vaca). Três Corações, mais particularmente, tornou-se o primeiro município produtor de leite do Sul de Minas, com uma produção de 18.865 mil litros em 1970.

Esses dados fornecem a indicação de que a empresa desempenhou, sem dúvida, um papel importante na melhoria da produção e da produtividade leiteira da região, particularmente nas áreas mais próximas aos seus postos de recebimento: favoreceu claramente a modernização das técnicas de produção, embora, como acabamos de ver, esse incentivo tenha sido dirigido prioritariamente a um número reduzido de fazendas. Não parece, no entanto, ter provocado o fim de outros cultivos. Numa primeira fase, pode ter relegado a um segundo plano de prioridades a produção de bens alimentícios de base, mas nunca isso chegou a significar um processo substitutivo, em decorrência da baixa rentabilidade do leite. Quando incentivou a expansão da pecuária leiteira da região, foi em pastagens naturais ou em áreas abandonadas pela produção cafeeira. ${ }^{12}$

Segundo pesquisa da empresa, a maior parte das propriedades de seus fornecedores é constituída de pastagens $( \pm 80 \%)$, qualquer que seja :o estrato a que pertençam. ${ }^{13}$ Essa constatação, no entanto, não define tais propriedades como tendo na pecuária sua principal atividade, porque, muitas vezes, as pastagens são terras cansadas ou acidentadas, que dificilmente poderiam servir para cultivo. Quanto à composição do rebanho, como se trata de uma bacia leiteira bastante antiga, já houve tempo suficiente para cruzamento com reprodutores leiteiros europeus e ele se constitui principalmente de gado cruzado (europeu-zebu).

As técnicas de produção leiteira utilizadas pelos fornecedores da Nestlé dependem, evidentemente, de sua capacidade de capitalização, que difere muito, segundo se trate de produção de excedentes ou de produção mercantil. Outro aspecto que deve ser considerado é o regional: na parte oeste, tradicionalmente uma área de produção de café e onde essa atividade foi intensificada, durante a última década, por um programa de incentivos oficiais, à modernização cafeeira se seguiu uma modernização das técnicas de produção leiteira: graças à sua maior rentabilidade, a cafeicultura tem condições de pagar salários mais altos à numerosa mão-de-obra que absorve e provoca uma diminuição da força de trabalho disponível para o setor leiteiro. Estimulou, assim, uma racionalização das técnicas produtivas deste último. Nas regiões não-cafeeiras, a baixa rentabilidade da produção leiteira tradicional freou o processo de modernização da última década.

\footnotetext{
${ }^{12}$ Isso é evidenciado no Censo: em 1950, 75\% da área foram classificados como "pastagen naturais e artificiais" e, em 1970, essa proporção tinha aumentado para 80\%, em prejuízo, principalmente, das terras não-utilizadas; as áreas de lavouras temporárias subiram, nesse intervalo, de $6,8 \%$ para $8,2 \%$.

13 Assistência Nestlé aos Produtores de Leite, 1973. Os dados provavelmente são superestimados, em virtude da forte proporção de grandes produtores na amostragem, e também porque certos pequenos produtores se agrupam para entregar seu leite, sendo levantados como um só produtor.
} 
$\mathrm{Na}$ área de recebimento como um todo, os estabelecimentos maiores alcançaram um nível de modernização muito alto: como se trata de uma área tradicionalmente leiteira, chegaram, ao longo dos anos, a uma infraestrutura bastante desenvolvida. Quanto a explorações menores, fizeram menos investimentos em instalações fixas e maquinaria agrícola, graças à sua menor capacidade de capitalização e ao caráter pouco compensador do preço do leite.

\subsection{Os fornecedores da fábrica de Três Corações ${ }^{14}$}

Uma primeira pergunta que se pode fazer é por que esses produtores preferem vender seu leite para o grupo transnacional e não para uma de suas pequenas concorrentes locais ou regionais.

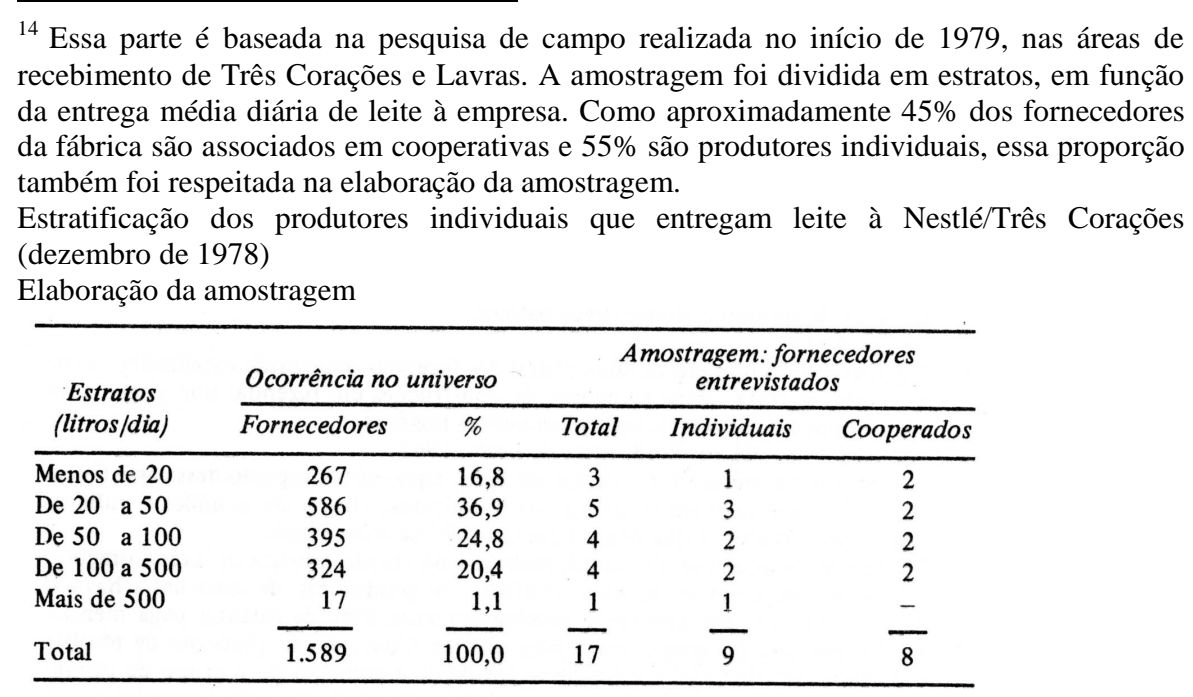

As entrevistas com os fornecedores se dividem em duas partes: a primeira, com o objetivo de caracterizar os produtores, corrobora, em grandes traços, o que foi descrito até agora; a segunda parte, que trata de sua situação atual como produtores de leite, de seus planos futuros e de sua relação com a empresa, será desenvolvida a seguir. Essas entrevistas com os fornecedores da Nestlé foram completadas por outras, com representantes de cooperativas, pequenos laticínios da região, técnicos de órgãos de assistência oficial, outros produtores de leite $\mathrm{C}$ e $\mathrm{B}$, e representantes locais da empresa.
Já vimos que a localização das linhas de leite é essencial e nem sempre muito dinâmica. A isso se soma o fato de que, geralmente, um produtor tem interesse em entregar seu leite, na safra, para o comprador com quem formou sua quota durante a entressafra. ${ }^{15}$ Esses dois aspectos dificultam, sem dúvida, a passagem dos produtores para uma nova empresa compradora.

O que mais motiva os produtores na escolha da empresa para a qual entregarão sua produção é, sem dúvida, o preço oferecido para o produto. O preço mínimo é tabelado, mas certas empresas podem preferir pagar alguns centavos a mais por litro, para garantir a manutenção do seu fornecimento: é o que acontece, frequentemente, quando uma empresa de porte maior se implanta numa região onde existe certa concorrência. Outro motivo importante é o da localização das fazendas em relação às usinas de beneficiamento: como o produtor é responsável pelo transporte do leite de sua fazenda até o posto de recepção e deste último até a usina, ele procurará entregar seu leite à usina mais próxima. Outra razão que os produtores gostam de citar, para explicar sua ligação a uma firma específica, é a garantia (relativa) que esta lhes dá para a compra de todo o leite produzido, durante todo o ano, graças à sua maior capacidade instalada.

A Nestlé apresenta mais um atrativo de peso para os produtores de leite da região: apesar de não pagar hoje um preço maior para o leite que o de concorrentes, é considerada urna empresa muito correta ("as outras prometem muito, mas não cumprem suas promessas"). Ela dispõe de capital de giro bem mais volumoso, e paga o leite recebido sempre em dia, sem atraso nem protesto, e ao preço combinado. As firmas menores, que lutam atualmente com sérias dificuldades financeiras, não oferecem a mesma vantagem para seus fornecedores.

Qual é a situação atual dos produtores da Nestlé na região?

\footnotetext{
${ }^{15}$ Ver a nota ${ }^{\circ} 11$ da Introdução (p.174).
} 


\section{Quadro 7}

\section{Estrutura de produção dos}

fornecedores individuais da Nestlé em Três Corações (1975-1978)

\begin{tabular}{|c|c|c|c|c|c|}
\hline \multirow[b]{2}{*}{ Produção diária } & \multicolumn{2}{|c|}{ Janeiro de 1975} & \multicolumn{2}{|c|}{ Dezembro de 1:978 } & \multirow[b]{2}{*}{$\begin{array}{c}\text { Diferença } \\
\text { entre }(a) \text { e (b) }\end{array}$} \\
\hline & $\begin{array}{c}\text { Número de } \\
\text { produtores (a) }\end{array}$ & $\%$ & $\begin{array}{c}\text { Número de } \\
\text { produtores (b) }\end{array}$ & $\%$ & \\
\hline Menos de 20 litros & 344 & 19,2 & 267 & 16,8 & -77 \\
\hline 20 a 50 litros & 667 & 38,6 & 586 & 36,9 & -81 \\
\hline 50 a 100 litros & 393 & 22,7 & 395 & 24,8 & +2 \\
\hline 100 a 500 litros & 303 & 17,5 & 324 & 20,4 & +21 \\
\hline Mais de 500 litros & 21 & 1,2 & 17 & 1,1 & -4 \\
\hline Total & 1.728 & 100,0 & 1.589 & 100,0 & -139 \\
\hline
\end{tabular}

Fonte: Elaboração da autora, a partir de dados fornecidos pela empresa.

A proporção observada entre o número de produtores e sua entrega diária de leite corresponde, aproximadamente, à estrutura fundiária da região: $70 \%$ dos estabelecimentos levantados pelo Censo de 1970 ocupam uma área de menos de 50ha (ou seja, 20\% da área total). De outro lado, a $16 \%$ dos estabelecimentos correspondem áreas de mais de 100ha (ou seja, $63 \%$ da área total).

Constatou-se, a partir de 1970, um reforço do processo de concentração fundiária, pela diminuição dos pequenos e médios estabelecimentos. $\mathrm{O}$ número total de estabelecimentos agropecuários na região também diminuiu de 21.777, em 1970, para 20.050, em 1975, apesar da incorporação de novas terras.

Isso foi provocado por um forte processo de valorização das terras. Esse processo ocorreu, principalmente, devido à expansão de cultivos modernos, destinados ao abastecimento das capitais, e também devido à implantação de um parque industrial em algumas cidades. Tal processo se nota principalmente na parte sul da região estudada, mais próxima ao Estado de São Paulo, e em volta de cidades que apresentam certo desenvolvimento industrial.

Voltemos ao Quadro 7: ele retrata a evolução da estratificação dos produtores, de janeiro de 1975 até dezembro de 1978: nesses três anos, 139 produtores abandonaram a empresa. As desistências se deram principalmente entre os pequenos produtores e não foram compensadas pelos ligeiros aumentos entre médios e grandes. Quanto à diminuição dos que entregam mais de 500 litros diários, é devida, provavelmente, à sua mudança para produção de leite B. As desistências foram maiores nas áreas de concorrência e não ocorreram com tanta frequência onde a Nestlé é a única recebedora, o que leva a crer que todos esses fornecedores não abandonaram necessariamente a produção leiteira.

A Nestlé não seria capaz de garantir a permanência de seus fornecedores, protegendo-os contra propostas de concorrentes? Parece mais que o grupo transnacional não está recorrendo ao esquema que montou para esse objetivo ("Antes, quando um fazendeiro pensava em largar a companhia, ela mandava técnicos para convencê-lo a ficar. Hoje, estão quase agradecendo ao produtor que quer sair").

$\mathrm{Na}$ época da pesquisa local (1979), todos os produtores da região se queixavam do baixo preço do leite e da sua pequena rentabilidade. Raros eram os que pensavam em continuar, no futuro, com a produção leiteira como principal atividade: somente quatro entre os 17 entrevistados - todos produtores de menos de 50 litros diários, que não tinham outras alternativas - declararam querer continuar produzindo leite nesses termos. Entre os outros pequenos produtores entrevistados, um se estava desfazendo de suas últimas vacas e trabalhando em fazendas vizinhas, um tinha parado recentemente e mudado para a cidade, e os outros estavam plantando café ou vendendo gado, reduzindo a importância de sua produção leiteira.

Entre os produtores maiores, muitos se dedicam à comercialização de gado e consideram a venda de leite uma atividade secundária. Para os fazendeiros que possuem gado comum, mestiço, é fácil passar para a venda de gado de corte, que lhes garante, atualmente, uma renda maior. Para os produtores mais capitalizados, porém, o problema é maior, porque fizeram investimentos, compraram gado leiteiro holandês, e estão ligados a compromissos bancários dos quais dificilmente conseguem livrar-se.

A falta de rentabilidade do leite se evidencia claramente nos investimentos feitos para a melhoria da produção leiteira. Essas melhorias foram pouco numerosas nestes últimos anos, mas, mesmo assim, os produtores compraram implementos agrícolas, reformaram pastos, 
plantaram capineiras, construíram silos etc. Independentemente de terem sido financiadas ou não, essas melhorias foram pagas de alguma forma, e os pagamentos não puderam ser efetuados exclusivamente com a renda de sua produção leiteira. Ao lado da venda de bezerros, comum a todos os estratos de produtores, os pequenos tiveram de completar essa quantia com a venda de excedentes agrícolas ou a venda de sua força de trabalho, e os produtores maiores, com venda de gado, terras, produtos agrícolas ou com recursos alheios à fazenda.

Todos os fornecedores se queixam da falta de rentabilidade do leite, mas eles se queixam, também, dos desestímulos que sofrem por parte da empresa: esta, durante a época da safra de 1978-1979, não aceitou um litro acima da quota que os produtores tinham apresentado durante a entressafra precedente, apesar de trabalhar somente com parte de sua capacidade instalada. Dessa maneira, obrigou seus fornecedores a desmamar as vacas antes da época ou a mandá-las para o abate.

Frente a todos esses desestímulos, frente a uma renda muitas vezes negativa, por que esses fornecedores continuam produzindo leite e entregando-o à empresa?

Como a maioria não contabiliza sua força de trabalho nem sua propriedade como custo, eles continuam sem perdas nem lucros, recebendo uma quantia de dinheiro líquido a cada mês. Esse dinheiro é essencial para pagar as despesas familiares como alimentação, vestuário e saúde, e algumas despesas mensais da exploração agropecuária, como a compra de rações, salários de empregados etc.: a produção leiteira fornece, mensalmente, ao produtor o capital de giro que lhe falta e que não consegue com a venda de suas colheitas agrícolas anuais. A renda do leite não é suficiente para permitir-lhe fazer investimentos, nem mesmo, muitas vezes, para cobrir os custos diários de sua exploração, mas é essencial, porque se trata de dinheiro líquido, com o qual ele pode contar para pagar parte de suas despesas mensais.

Ao produtor faltam alternativas que lhe garantam uma renda imediata e regular desse tipo. A atividade leiteira, mesmo não sendo rentável, é uma atividade segura: a certeza de conseguir vender a produção quase toda e a regularidade do pagamento compensam a fraca rentabilidade constatada.
Para todos os produtores, existe um risco sério em reorientar sua produção. Os grandes, ainda mais, têm capitais importantes imobilizados na exploração leiteira. Quanto aos pequenos, faltam-lhes, muitas vezes, alternativas de emprego, na agricultura ou em outro setor da economia.

O caráter complementar da pecuária leiteira, nesses estabelecimentos, favorece, sem dúvida, a empresa, porque lhe permite uma maior flexibilidade em termos de recepção: uma recusa de leite da sua parte provocará menos conflitos com seus fornecedores que no caso em que estes dependessem exclusivamente desse produto para sua subsistência. No caso que estudamos aqui, a empresa tem facilidade em transferir o risco da comercialização de seus produtos para seus fornecedores, adaptando seu recebimento a suas estratégias de mercado.

\subsection{Tendência migratória da Nestlé no Brasil}

É difícil distinguir o caráter da redução do recebimento da empresa em Três Corações: pode ser uma política passageira ${ }^{16}$ como pode significar, também, um desestímulo profundo à pecuária leiteira regional, se continuada a longo prazo. Esse fenômeno não pode ser devido somente a uma decisão da Nestlé em diminuir sua produção de leite em pó, porque está abrindo novas fábricas em outras regiões. Pode estar ligado, no entanto, a uma tendência constante no comportamento do grupo suíço, verificada tanto no Brasil quanto em outros países da América Latina ${ }^{17}$ : a tendência em se afastar cada vez mais dos núcleos industriais, criando novos centros mais dinâmicos para a produção de leite.

Nas regiões tradicionais, o setor leiteiro não consegue mais se expandir de maneira satisfatória para a empresa. Isso se deve, principalmente, ao caráter extensivo dessa atividade: a distância existente entre a elevação do preço da terra e o rendimento da pecuária leiteira ao produtor não permite maior expansão da produção. A empresa procura,

16 A empresa costuma recorrer a mecanismos de pressão para aumentar o preço de seu produto acabado no mercado consumidor. Manobras desse tipo são possíveis, graças à sua vantajosa posição no mercado de leite em pó (ver, por exemplo, "Produtores dizem que leite em pó integral vai sumir do mercado", in Folha de São Paulo, 29 de abril de 1977).

${ }^{17}$ Nestlé S.A., 1975. Essa tendência foi verificada em todos os países de pecuária extensiva e com condições de criar novos pólos de expansão leiteira. 
pois, regiões mais afastadas dos grandes centros urbanos, onde o preço da terra é mais barato e onde ela pode controlar a produção leiteira em condições de monopsônio absoluto: foge, assim, aos altos custos de produção, à concorrência na procura de sua matéria-prima e às acusações de diminuir o abastecimento de leite fluido nas capitais. É mais lucrativo, para a empresa, implantar uma fábrica em nova região do que lutar contra fatores estruturais que impeçam a expansão do setor leiteiro tradicional. Essa diminuição dos estímulos da Nestlé à pecuária de determinada região é facilitada pelo fato de que os produtores já criaram alguns mecanismos para absorver os riscos da comercialização leiteira.

Nessa tendência para a expansão territorial em áreas potenciais ainda pouco exploradas, a empresa contou, no Brasil, com a colaboração das políticas de incentivos fiscais regionais da Sudam, na Região Amazônica, e da Sudene, no Nordeste. Esses incentivos à desconcentração industrial vieram ao encontro de sua necessidade de expansão territorial, que surge em todo país em que a empresa esteja implantada há várias décadas, perto de centros urbanos de alto crescimento.

O estudo da situação em Três Corações, caso de implantação antiga da Nestlé, onde o leite já não é mais um produto dinâmico, poderia ser completado por uma pesquisa de campo numa região de instalação recente. Assim, poder-se-ia comparar a atuação da empresa em dois lugares: um, de expansão da produção leiteira, e outro, de quase-estagnação. Note-se que a atuação do grupo suíço na região estudada foi importante principalmente em sua época de implantação, quando teve de organizar e disciplinar seu mercado fornecedor. Depois, uma vez assegurado seu fornecimento, seu papel na região se tornou mais conservador. Por essa razão, seria interessante estudar, também, o caso de uma região de implantação recente da empresa.

\section{O leite em pó na ideologia dominante: a luta do seio contra a mamadeira}

A amamentação é parte integrante do processo reprodutivo; é a maneira natural e ideal de alimentar o lactente, constituindo uma base biológica e emocional inigualável para o desenvolvimento da criança.
Esse e outros efeitos importantes do aleitamento materno na prevenção de infecções, na saúde e bem-estar da mãe, no intervalo entre partos, na saúde da família, na própria família, na economia nacional e na produção de alimentos fazem com que a amamentação seja um aspecto vital da autoconfiança, dos cuidados primários de saúde e das atuais estratégias de desenvolvimento. Por essa razão, cabe à sociedade promover o aleitamento materno e proteger as mães grávidas e os lactentes de quaisquer influências que possam romper esse processo.

Declaração sobre alimentação de lactentes e crianças na primeira infância. Reunião Conjunta, Organização Mundial da Saúde/Unicef,

Genebra, 9-12 de outubro de 1979.

\subsection{Introdução}

Já faz algumas décadas que um problema precisa ser resolvido, a cada vez que nasce uma criança: como alimentá-la, no seio ou na mamadeira? Isso só se transformou em problema a partir do momento em que os preparados artificiais para recém-nascidos se tornaram disponíveis no mercado. Anteriormente, todas as mulheres seguiam a tradição de suas avós e de suas mães, amamentando seus filhos. No caso de a mãe não poder ou não querer amamentar, o bebê era confiado a uma ama-de-leite, e isso não significava nenhuma tragédia.

Atualmente, a situação é bem diferente: a mãe tem de escolher se alimentará seus filhos no seio ou na mamadeira. Essa é uma opção individual sua, mas, junto com as opções individuais de milhares de outras mães, acaba envolvendo grandes interesses comerciais. Uma única empresa virtualmente monopoliza, no Brasil, o mercado de leite em pó modificado para uso infantil: a Nestlé. É esta a principal empresa envolvida no lucrativo negócio de vender leite "maternizado" a mulheres que, quase sempre, têm todas as condições necessárias para alimentar seus filhos de maneira natural e autônoma.

\subsubsection{O seio perdeu a primeira partida}

As informações dadas às gestantes, por ocasião de exames pré-natais ou de sua internação nas maternidades, quase nunca abordam a questão da 
amamentação, como se a escolha entre alimentação natural ou artificial não acarretasse consequências importantes. Tal escolha é considerada um aspecto secundário, que habitualmente será resolvido dentro da própria rotina do hospital, até fora do conhecimento e da aquiescência das mães.

A falta de informações por parte das mães e sua crescente integração no esquema de produção e de consumo capitalista parecem ter levado a uma diminuição do aleitamento tradicional ao seio. Essa evolução foi constatada em todos os países de economia capitalista e em todas as camadas sociais, estendendo-se, gradualmente, dos países ricos para os pobres e das classes sociais mais privilegiadas para as classes trabalhadoras e marginais. ${ }^{1}$

No Brasil, vários estudos regionais realizados entre 1958 e 1969 demonstraram, como era de esperar, uma diferença notável entre a situação no campo e nas cidades. Verificou-se que, em várias áreas rurais do país, o período médio de amamentação natural era superior a nove meses. Nas regiões Urbanas e suburbanas dos Estados do Nordeste, do Rio de Janeiro e de Minas Gerais, ao contrário, o período da amamentação tem sido de cerca de três meses (Ulloa, [s/d]).

\subsubsection{Perigos da alimentação artificial}

A utilização de fórmulas artificiais tem acarretado graves consequências para muitos recém-nascidos. Cada vez mais acumulam-se dados que provam a superioridade incontestável do leite materno, tanto do ponto de vista nutricional e imunológico, quanto da necessidade de um contato mais intenso entre filho e mãe.

É bastante conhecido, entre os pediatras, o fato de que crianças alimentadas com mamadeira adoecem mais facilmente que as amamentadas no seio. Essas últimas apresentam taxas de morbidade e de mortalidade bem mais baixas que as alimentadas de maneira exclusivamente artificial. Estudos realizados também no Brasil confirmam essa constatação geral (Martins Filho, 1977).

${ }^{1}$ Um estudo significativo foi realizado nesse sentido, por exemplo, no Chile. Segundo esse trabalho, no final da década de 1950 , somente $5 \%$ das crianças chilenas de um ano eram alimentadas artificialmente. No início da década de 1970, essa proporção tinha chegado a $80 \%$ das crianças de dois meses de idade, sendo que elas apresentavam uma taxa de mortalidade três vezes mais alta que as outras, alimentadas ao seio (Plank e Milanesi, 1973).
Tal fenômeno toma proporções mais agudas ainda, quando o relacionamos com a origem social das crianças. Nas classes populares, a substituição da amamentação natural por urna mamadeira de leite em pó quase sempre provoca infecções e desnutrição. Pode, até mesmo, levar à morte. O problema colocado pelo alto preço dos preparados artificiais é essencial. ${ }^{2}$ Para compensar essa despesa, muitas mães administram o leite aos seus filhos excessivamente diluído, mesmo sabendo que isso diminui a capacidade nutritiva do produto. Somam-se, a esse fato, as péssimas condições higiênicas e sanitárias em que vive grande parte da população brasileira, e que não permitem seguir as instruções relativas ao uso de água pura, à esterilização das mamadeiras etc. Muitas mães são analfabetas e não leem a posologia indicada na lata, enquanto outras não têm geladeira para conservar o preparado. A administração de leite em pó acaba provocando, assim, sérios problemas de infecções respiratórias e gastrintestinais, alergias etc. ${ }^{3}$

Para as crianças provenientes de famílias de baixo nível econômico, o leite materno representa, sem dúvida, a fonte de proteínas mais simples, mais econômica e menos sujeita a contaminação. A amamentação natural, contudo, tem outra função importante: a de método de controle da natalidade. Sabe-se que é um método biológico eficaz para aumentar o intervalo natural existente entre partos sucessivos.

Nas camadas urbanas mais privilegiadas, a utilização de mamadeira interfere menos na saúde física do bebê. Estudos recentes, no entanto, provaram que pode levar a problemas de obesidade. Atualmente, está sendo pesquisada, também, a relação que parece existir entre alimentação artificial

\footnotetext{
${ }^{2} \mathrm{Na}$ época de redação deste trabalho (agosto de 1980), o custo de alimentação de cada criança de seis meses com leite modificado representava, aproximadamente, $18 \%$ do salário mínimo vigente. O aleitamento materno evitaria, portanto, importantes despesas, tanto no nível familiar quanto em nível macroeconômico.

${ }^{3} \mathrm{O}$ trabalho mais completo a esse respeito é o de Jelliffe e Jelliffe (1979). Um estudo sobre cuidados higiênicos e diluição do leite na preparação de mamadeiras, realizado em um distrito da cidade de São Paulo, revelou dados impressionantes nesse sentido: 96\% das mães classificadas no grupo socioeconômico mais baixo não seguiam as instruções segundo as quais devem ferver todo o material cada vez que preparam uma mamadeira. Quanto à diluição do leite, $49 \%$ não colocavam as quantidades aconselhadas, errando para mais ou para menos (Ulloa, [s/d]).
} 
e a frequente ocorrência de hipertensão e doenças coronárias na idade adulta.

Não só do ponto de vista fisiológico a amamentação natural tem um papel importante a desempenhar; também no desenvolvimento psíquico da criança, um contato íntimo e uma troca afetiva profunda entre mãe e filho são essenciais. Essa troca será facilitada pelo calor emocional e físico da amamentação, que é fonte de prazer tanto para a criança quanto para a mulher que amamenta.

\subsubsection{Na luta entre o seio e a mamadeira, o árbitro é a ideologia}

Apesar dos fatos enumerados anteriormente, comprovados e repetidos em numerosas pesquisas científicas, a proporção de mulheres que escolhem a amamentação natural está diminuindo cada vez mais.

O processo de urbanização da sociedade brasileira levou à introdução de novos hábitos, mais integrados no mundo do consumo que os anteriores.

Dentro desse processo, é interessante estudar o exemplo da desvalorização do leite materno, porque esta é claramente contrária aos interesses da maior parte da população do país, provocando sérios problemas de desnutrição e de mortalidade infantil.

Neste capítulo, propõe-se estudar as causas do processo supracitado na sociedade brasileira: quais são as razões alegadas pelas mães para renunciar à amamentação natural? Qual é a carga ideológica que transparece em suas argumentações? Quais são os interesses das multinacionais do leite nesse processo? Como conseguem influenciar as mães, e a sociedade como um todo, no sentido de favorecer seus negócios? Qual é a participação dos médicos pediatras e dos outros profissionais de saúde em tudo isso? Como o Estado vem intervindo nessa clara luta de interesses?

Mais importante, porém, do que uma simples enumeração de fatos, é a descrição do conflito latente, mais profundo, entre duas "concepções de vida" antagônicas: a tradicional, "baseada numa certa autonomia relativa das classes populares frente ao consumo de produtos supérfluos e de alto valor agregado, e a concepção de vida "moderna", urbanizada, imposta pelos interesses de acumulação do capital industrial. Essa imposição gradual, que acontece de maneira conflitiva e dialética, exige uma mudança na atitude da população consumidora frente a suas condições de existência. Somente através de mudanças ideológicas profundas, o capital conseguirá provocar as novas necessidades e os novos hábitos de consumo de que necessita em sua luta contra a tendência à queda de sua taxa de lucro.

\section{É o que estudaremos a seguir.}

3.2 Por que as mães brasileiras estão abandonando o aleitamento natural?

A tendência à alimentação artificial de recém-nascidos está-se espalhando entre todas as camadas sociais (e principalmente entre as classes urbanas e periurbanas), com uma força pouco suspeitada. Até nas favelas, as mães frequentemente recorrem à mamadeira de leite em pó para alimentar seus filhos. Um trabalho feito numa favela de Santos, por um posto da prefeitura daquela cidade, revelou que, em 1974, 92,6\% das crianças da favela com idade abaixo de um ano eram alimentadas artificialmente. O trabalho da equipe do posto se dirigiu principalmente para inverter essa situação. Um ano mais tarde, a proporção de crianças de menos de dez meses que eram amamentadas já tinha alcançado $45 \%$. Acontece, no entanto, que um remanejamento na equipe reduziu sua preocupação com esse problema: em 1977, a situação estava voltando à que existia no início do trabalho, ou seja, mais de $75 \%$ das crianças já estavam sendo alimentadas artificialmente (Silva, 1977).

Essa experiência demonstrou que, mesmo entre a população urbana mais carente, para quem a compra de leite representa uma importante despesa adicional e os riscos da contaminação são os maiores, a tendência a recorrer à alimentação artificial é predominante. Mas demonstrou, também, como a atitude médica pode interferir ativamente para inverter essa tendência.

Por que razão mulheres sadias, que têm todas as condições necessárias para amamentar seus filhos — impossibilidades fisiológicas são encontradas em menos de 5\% das mães — insistem em alimentá-los com mamadeira, expondo-se, assim, a infecções e desnutrição? 


\subsubsection{Leite "fraco" ou "insuficiente"}

As razões que as mães alegam, quando interrogadas a esse respeito, são principalmente a má qualidade ou a insuficiência do seu próprio leite. Isso foi constatado tanto a nível mundial (cf. Jelliffe e Jelliffe, 1979), quanto ao nível da situação no Brasil. Neste país, várias pesquisas demonstraram que cerca de $70 \%$ das mães desmamam precocemente seus filhos pelas razões de "leite insuficiente", "a criança não quis mais", "o leite era fraco" ou "o leite secou" (Ulloa, [s/d]; Souza, 1974; Aragão, 1977).

No entanto, a má qualidade e a fraqueza do leite citadas parecem não só ser extremamente relativas, como traduzir antes uma insegurança da mãe, frente à sua própria capacidade de amamentação, que um fato cientificamente demonstrado: tanto em volume quanto em composição, o leite materno de mulheres desnutridas é adequado para sustentação de seus filhos, além de conter os anticorpos necessários à sua defesa. A mãe precisa chegar a um estágio particularmente grave de desnutrição para que seu leite não contenha as calorias, vitaminas e proteínas necessárias ao desenvolvimento do lactente. E, mesmo nesses casos, o leite materno deve ser melhor do que qualquer outro tipo de alimento, uma vez que a mãe altamente desnutrida não dispõe de comida de boa qualidade para oferecer aos seus filhos.

No caso de insuficiência de leite, vários estudos médicos verificaram que complementar a amamentação com leite em pó modificado não seria a melhor solução: isso não só diminui gradativamente a secreção do leite materno, mas aumenta, também, a ocorrência de morbidade e mortalidade infantil. De outro lado, existe uma solução mais saudável e mais racional para resolver esse problema: a complementação equilibrada da dieta da mãe durante o período de lactação. Essa complementação alimentar da mãe, quando feita com base em verduras e cereais, não representa, de forma nenhuma, uma despesa maior para o orçamento familiar do que a compra de leite em pó, e significa uma segurança adicional para a saúde da criança (OMS/Unicef, 1979).

As razões alegadas acima - má qualidade e insuficiência do leite materno - não encontram, na grande maioria dos casos, comprovação científica. As mães entrevistadas parecem traduzir, com essas palavras, fortes pressões socioculturais, econômicas ou emocionais, que inibem seu reflexo de liberação de leite.

O ambiente impessoal e pouco tranquilizante dos serviços de saúde no Brasil contribui, sem dúvida, para o agravamento desse fenômeno. Nas maternidades, os médicos têm pouco tempo disponível para dar uma orientação pessoal a suas pacientes. O recém-nascido é separado de sua mãe e levado automaticamente para um berçário: a possibilidade de a mãe se sentir apreensiva e insegura, no ambiente hospitalar, pode inibir seu reflexo de lactação e provocar, assim, insatisfação na criança. Seus choros, por sua vez, serão interpretados como "leite insuficiente" ou "inadequado", e se recorrerá à alimentação artificial complementar, o que pode aumentar a insegurança da mãe frente a seu próprio leite, e diminuir-lhe, mais ainda, a quantidade, uma vez que é produzido em função da sucção do lactente.

Atualmente, todo o esquema de propaganda das empresas de leite em pó é montado em cima dessa inibição psicológica do reflexo natural de lactação: "O melhor leite é o materno. Mas, na falta deste, dê leite Nestlé para seu filho." As mães visadas pela propaganda não sabem que um impedimento fisiológico real só existe em menos de 5\% das mulheres. Vão considerar, pois, a inibição de seu reflexo de lactação como um fenômeno normal, e não lutarão ativamente para alterá-lo.

É importante, também, mencionar a evolução da atitude da sociedade em relação aos seios da mulher: de um símbolo fundamentalmente maternal e nutritivo, passaram a ser enfatizados, na época atual, em função de seu lado estético e erótico-sexual. As empresas de leite em pó acabam, pois, sendo beneficiadas pelos apelos profundamente eróticos a que recorrem outras empresas, em sua propaganda, utilizando os seios femininos como um "objeto que faz vender".
${ }^{4}$ Em relação a isso, é interessante mencionar que, segundo vários estudos recentes, não é a
amamentação em si que provoca um envelhecimento prematuro dos seios. A razão principal
desse fenômeno seria, em casos de gravidezes sucessivas, um relaxamento muscular geral,
que pode ser intensificado pela idade e por uma falta de cuidado da mulher com seu próprio
corpo.
159 
3.2.2 Classes sociais, expansão do capitalismo e diminuição da amamentação

No processo de industrialização e urbanização da sociedade, é inegável que os alimentos artificiais para recém-nascidos estão preenchendo uma junção importante: permitem a alimentação da criança sem exigir a presença da mãe, no caso de mulheres que precisam ausentar-se de casa para trabalhar, por exemplo. A crescente integração da mulher no processo de produção capitalista é, sem dúvida, uma das principais razões que impedem a divulgação da amamentação materna na sociedade brasileira. Como a legislação social lhe garante somente dois meses de férias depois do parto, ela será levada a abandonar a amamentação quando voltar a trabalhar.

$\mathrm{Na}$ situação atual, porém, este problema parece apresentar dimensões ainda reduzidas: as publicações existentes indicam que a proporção de mulheres que deixam de amamentar seus filhos por razões profissionais é notavelmente pequena (ver, por exemplo, o estudo referente a vários países do centro e da periferia, citado em Jelliffe e Jelliffe, 1979). Isto se deve provavelmente ao fato de que grande parte das mulheres trabalhadoras exercem sua profissão no próprio ambiente doméstico e familiar (empregadas domésticas, lavadeiras, camponesas etc) ou que já abandonaram seu emprego antes de a criança nascer.

Essa constatação foi confirmada, no caso brasileiro, por uma investigação realizada em uma cidade fortemente industrializada, pertencente à grande São Paulo (Aragão, 1977). Somente 2\% das mulheres entrevistadas naquela ocasião citaram seu trabalho como sendo a razão que as impedira de amamentar seus filhos, apesar de se tratar de uma região onde o trabalho feminino é comum. E essa proporção ainda poderia diminuir se fosse aplicada a legislação social que garante a existência de creches e dá às mulheres trabalhadoras o direito de deixarem seu local de trabalho toda vez que precisarem amamentar seus filhos (art. 399 da Consolidação das Leis do Trabalho). Essa legislação nunca foi aplicada na prática.

Não é necessário, porém, que as mulheres comecem elas próprias a trabalhar num esquema de produção capitalista, para que abandonem a amamentação. Em extensas áreas rurais tradicionais do país, por exemplo, observações médicas demonstraram a relação existente entre a expansão das relações de trabalho capitalistas e uma frequente redução da qualidade de vida e do nível de nutrição da população. A adoção de uma agricultura especializada leva ao abandono progressivo do cultivo de produtos de subsistência e a uma monetarização da sociedade rural, que permite a chegada, ao campo, de mercadorias anteriormente reservadas à população urbana. Graças ao processo de aculturação que acontece de maneira paralela, é incentivado o aparecimento de novas necessidades, tal como a da mamadeira e a do leite em pó.

Nas grandes cidades, os migrantes recém-chegados passam por um processo de aculturação mais violento ainda, e acabam tornando-se as principais vitimas do que começou a ser chamado de "desnutrição comercialogênica". O estudo de Mike Muller (1974), citado a seguir, demonstra que as camadas populares mais atingidas pelas pressões das transnacionais do leite em pó são formadas por ex-camponeses e trabalhadores rurais expulsos do campo, que vêm reforçar o exército industrial de reserva das metrópoles. O rompimento de seus laços socioculturais de origem provoca um "vazio ideológico", que os torna uma presa fácil para qualquer tipo de mensagem publicitária. Essa constatação amplia a tese de que, quanto mais baixa a classe social, tanto menos crítica sua atitude frente à mensagem publicitária, pelo seu menor conhecimento das técnicas de persuasão utilizadas (Cornaton, 1968).

A integração gradual das mulheres na sociedade capitalista, com sua organização urbana e consumista, implica uma diminuição correspondente de sua vontade de amamentar. Um estudo realizado em Campinas, entre 1974 e 1976 (e citado em Dias, 1977), demonstrou que um grupo de mães que tiveram mais de sete consultas pré-natais aleitaram seus filhos durante um período médio de dois meses e três dias. Para as mães que fizeram de um a seis exames médicos durante sua gravidez, o período de amamentação subiu para dois meses e 19 dias. Quanto às mulheres que não tiveram nenhuma consulta pré-natal, o tempo de aleitamento foi de cinco meses e 21 dias.

Esses dados podem ser interpretados utilizando o número de consultas pré-natais como indicador do grau de integração das mães no esquema de consumo capitalista: quanto maior o número de consultas, tanto maior o poder aquisitivo das mães e sua tendência ao consumo. As 
mulheres que não contaram com nenhuma consulta, ao contrário, vivem à margem das instituições de saúde e assumem a alimentação de seus filhos de um modo mais autônomo. 5

\subsubsection{A mamadeira dá "status"}

A grande maioria das mães não sabe indicar exatamente com que motivação escolheu a alimentação artificial para seus filhos. Uma razão que contribui para a inibição do reflexo natural de lactação deve ser procurada no prestígio ligado a um modo de vida moderno, urbanizado e que exige a adoção de novos hábitos de consumo. A valorização do "moderno" é intimamente ligada ao crescimento da oferta de produtos supérfluos. A propaganda divulgada pelos meios de comunicação de massa tenta provocar uma identificação dos ouvintes ou leitores com um "consumidor ideal". A esse "consumidor ideal", "homem e mulher modernos", radiantes de felicidade graças a suas opções consumistas, contrapõem-se o fracasso: a pobreza e o atraso das populações de tradição rural. "Inculto", "supersticioso", "sujo", "atrasado", "burro", o camponês tradicional representa, em sua autossuficiência, as raízes que o "homem moderno" precisa superar.

Dentro desse quadro, a mamadeira de leite em pó é um ótimo símbolo do modern way of life: mais "moderna", "higiênica", "científica" - e mais cara - que o aleitamento tradicional. Este, por sua vez, é desprestigiado e reservado às mulheres "caipiras".

Existe, também, uma relação inegável entre o ritmo agitado da vida urbana, que facilita o aparecimento de nervosismo e de estresse, e a inibição do reflexo de lactação, mencionada anteriormente. Nas comunidades rurais tradicionais, as mulheres encontram as condições de que precisam para viver e assumir seu papel de reprodutoras com tranquilidade. Nas cidades modernas, ao contrário, elas passaram a se envolver em situações que ultrapassam o âmbito restrito da reprodução e da alimentação familiar: o ritmo acelerado dos acontecimentos que as rodeiam, a divisão do trabalho - cada vez menos rígida - entre homem e mulher, assim como a maior

\footnotetext{
${ }^{5}$ Segundo outra interpretação, seriam os próprios profissionais da saúde que colaborariam para um desmame mais rápido. Essas duas interpretações dos dados não se excluem e são válidas. Continuarão sendo aprofundadas em sua ação recíproca, ao longo deste trabalho.
}

participação feminina no processo produtivo fizeram com que muitas mulheres assumissem responsabilidades mais diversificadas do que anteriormente.

Passaram, então, a ser constantemente requisitadas por numerosas atividades, que tornaram sua vida mais agitada e as privaram do clima de tranquilidade necessário a uma boa lactação. Por outro lado, é possível que essas mulheres prefiram — mesmo inconscientemente — administrar a mamadeira aos seus filhos para ganhar tempo para outras atividades, uma vez que a amamentação natural exige sua presença de maneira imperativa.

Os diferentes fenômenos mencionados acima exercem fortes pressões sobre as mulheres que estão em condições de amamentar. São essas pressões que elas traduzem por meio da informação de que pararam de alimentar seus filhos com leite materno, porque este seria "fraco" ou "insuficiente".

\section{3 ... E as empresas de leite em pó modificado para crianças?}

De 1957 para 1974, o número anual de nascimentos nos EUA caiu de 4,3 milhões para 3,1 milhões. Essa queda da natalidade, geral nos países de industrialização mais antiga, provocou uma queda correspondente no faturamento das indústrias de alimentos infantis nesses países. Para conservar sua taxa de lucro, elas tiveram de alterar suas estratégias de venda: aumentar a diversificação de suas linhas de produção e expandir suas vendas em mercados da periferia, cuja população está crescendo constantemente. ${ }^{6}$

\subsubsection{O "matador de bebês"}

Tais indústrias se instalaram, com fortíssimos esquemas de propaganda, em países que frequentemente não dispunham de redes de comercialização capitalista desenvolvidas, nem de mecanismos de controle ou de reação a esse tipo de publicidade.

${ }^{6}$ Os laboratórios Abbott, por exemplo, expandiram suas vendas internas de leite modificado para uso infantil de somente 9\% entre 1972 e 1973, enquanto seus negócios no exterior aumentaram em 32\% (Kucinski e Ledogar, 1977). 
Em 1974, um estudo publicado na Inglaterra sob o título evocativo de The baby killer ( $O$ matador de bebês) descreveu as consequências decorrentes dos métodos de venda de leite em pó pela Nestlé e a Cow \& Gate em alguns países africanos, asiáticos e centro-americanos (Muller, 1974).

As empresas recorriam a enfermeiras encarregadas de vender seus produtos, e estas visitavam as mães, nas maternidades ou em suas casas, distribuindo frequentemente amostras grátis. Em certos países, criaram estabelecimentos comerciais onde vendiam leite modificado, com descontos especiais, para as mães com menos recursos. Esses métodos de venda ainda eram reforçados por campanhas publicitárias maciças, doação de alimentos infantis e colocação de cartazes publicitários em maternidades etc. ${ }^{7}$

Depois de uma descrição detalhada da maneira pela qual a Nestlé e a Cow \& Gate impuseram seu produto, o autor demonstrou como a introdução do aleitamento artificial nesses países levou a graves problemas de desnutrição e de mortalidade infantil (daí, o título $O$ matador de bebês).

Na Suíça, The baby killer foi traduzido em alemão e publicado sob um novo título: Nestlé é responsável pela morte de milhares de bebês. A empresa reagiu contra esta citação explícita, movendo um processo contra o grupo responsável pela tradução, que acordou a opinião pública europeia para esse problema. No julgamento, a empresa foi aconselhada a mudar o estilo de sua propaganda, considerada como sendo imoral e não-ética em sociedades subdesenvolvidas.

Nos EUA, por outro lado, foi lançada, em 1977, uma campanha nacional de boicote aos produtos Nestlé, seguida, em 1978, por inquéritos, no Senado, sobre as atividades das empresas de leite em pó para crianças.

\footnotetext{
${ }^{7}$ Informações mais detalhadas sobre as práticas de venda das transnacionais de de leite em pó podem ser encontradas em Schweizerische Arbeitsgruppe for Entwicklungspolitik, 1974; Arbeitsgruppe Dritte Welt Bern, 1976 e Lappé e Collins (1977), além da já citada pesquisa de M. Muller (1974). Esses trabalhos denunciam a maneira violenta pela qual essas empresas impunham seus produtos em países periféricos.
}

\subsubsection{Mudança de tática}

Apesar dessas denúncias, as empresas citadas não pararam com a distribuição de leite em pó nos países da periferia: são extensos mercados onde esse produto de fabricação barata e de alto preço já tem uma aceitação popular generalizada. ${ }^{8}$ Por outro lado, as empresas precisam desses mercados porque seus países de origem não comportam mais condições de crescimento da demanda de alimentos infantis, como vimos anteriormente.

Não suspenderam a produção de leite em pó, mas mudaram radicalmente seu esquema de propaganda: os excessos denunciados foram desaparecendo aos poucos e a publicidade tornou-se mais sutil e difusa. A filial brasileira da Nestlé, por exemplo, abandonou, pelo menos nas grandes cidades, a prática de entregar latas de leite em pó para todas as mães que deixem as maternidades, como tinha feito anteriormente. Parou também com as campanhas publicitárias de massa para divulgar esse produto.

A estratégia da empresa no Brasil hoje não se dirige prioritariamente às consumidoras diretas, que seriam as mães, e sim aos seus principais conselheiros, os médicos pediatras, na esperança de que o saber médico se torne um intermediário na difusão de sua ideologia e, pela mesma ocasião, de seus produtos.

\subsection{A ideologia da comunidade de interesses}

Muito receosa das críticas segundo as quais seria responsável por desnutrição infantil em vários países, a Nestlé demonstra um extremo cuidado quando libera informações sobre seu funcionamento e suas atividades nos países periféricos. Aí, realiza um importante trabalho para apagar as contradições existentes entre seus interesses próprios e os das classes populares.

Como consegue resolver essa contradição? Realçando sua utilidade pública e falando de incentivo à produção leiteira nacional, pesquisa

${ }^{8} \mathrm{O}$ leite maternizado, ou leite modificado para uso infantil, é um leite de vaca desnatado ou semidesnatado (subproduto da fabricação de manteiga), diluído a um terço, aumentado em sua lactose e acrescido de óleos vegetais e vitaminas. Essa mistura barata poderia eventualmente ser vendida pela metade do preço do leite integral (Barbosa Filho, 1977, p.120). Atualmente, seu preço é mais caro. 
nutricional, trabalho junto a médicos pediatras etc. ${ }^{9}$ Desenvolve esses temas para mostrar como consegue alcançar "ao mesmo tempo, a felicidade de seus acionistas e das populações junto às quais trabalha no Terceiro Mundo" (Veiga, 1976).

Essa "comunidade de interesses" levantada por Veiga será analisada, aqui, em tomo de dois aspectos básicos, o de sua tarefa pediátrica e o de seu impacto econômico e humanitário nos países em que atua.

\subsection{1 "A Serviço dos profissionais de saúde"}

\section{A Nestlé e os médicos pediatras}

A indústria suíça enfatiza constantemente suas atividades no meio médico e quer ser vista como se colocando "a serviço da pediatria". Sua atuação nesse sentido é múltipla: patrocina congressos, organiza cursos de atualização para pediatras, faz doações a universidades e hospitais, edita o Boletim Informativo da Sociedade Brasileira de Pediatria e duas revistas científicas de pediatria. ${ }^{10}$ Citando as palavras da empresa:

${ }^{9}$ E bem óbvia a influência que grandes corporações tais como a Nestlé podem exercer sobre a opinião pública, através de artigos de jornalistas especializados. A estratégia das filiais da empresa não deve diferir da de sua matriz: procura-se, primeiro, um jornalista conhecido, que poderia ser favorável à sua causa. O serviço interno de publicidade da empresa o informa sobre os problemas a serem tratados e providencia, para ele, os documentos necessários. É preciso que ele sempre conserve um tom de "objetividade": "É excelente que o Sr. Keller nos assista escrevendo artigos sobre multinacionais, mas deve-se evitar que pareça ser pago pelas corporações. Isso privaria seus artigos de toda credibilidade (...) Seria também útil procurar saber como ele poderia ajudar-nos a melhorar a imagem das grandes firmas, mas aqui também deveria ser evitado que sua colaboração com o nosso grupo minasse a influência que tem sobre seus leitores e diminuísse, assim, o valor do que ele faz". (Carta de G. Altwegg, Diretor Associado da Nesfie suíça, a H. Fehr, Vice-Diretor da Hoffinan-La Roche, em 23 de novembro de 1973, citada em The infiltration of the UN system by multinational corporations, [s/d], p.40).

${ }^{10}$ A empresa enumerou, em seu relatório de diretoria de 1976, por exemplo, sua colaboração aos seguintes acontecimentos durante o ano de 1975. "Curso Nestlé de Atualização em Pediatria", Juiz de Fora (MG); "Encontro Nestlé de Prática Pediátrica", Uberaba (MG); "Curso de Neonatologia", Manaus; "Primeira Jornada Campista de Pediatria", "Sexta Jornada Fluminense de Pediatria" e "Primeira Reunião Materno-Infantil de Campos", Campos; "Décimo Curso de Atualização em Pediatria do Hospital Andarấ", Rio de Janeiro; "Segunda Reunião de Pediatria Social dos Estados Nordestinos", Aracaju; "XI Congresso
Esses cursos, como também palestras, ciclos de conferências e congressos, com a presença dos maiores nomes do país e do exterior na matéria, têm sido a maneira que encontramos de levar aos médicos dos mais diferentes pontos do país a nossa contribuição para que se estabeleça um intercâmbio de informações e [que eles] recebam as ideias mais novas em seu importante campo científico. (Cinquenta anos de uma presença familiar $[\mathrm{s} / \mathrm{d}]$ )

Esse tipo de atuação resulta numa influência direta na formação dos pediatras brasileiros e num importante controle das informações que podem chegar até eles, seja através de publicações especializadas, seja através de cursos ou congressos.

A produção escrita da pediatria brasileira é quase totalmente controlada pela empresa. Esta aproveita seu controle para difundir sua ideologia ou para, pelo menos, impedir que seja questionada. O mesmo fenômeno pode ser apontado em sociedades e congressos médicos e começa a ser denunciado pelos próprios pediatras:

Algumas sociedades especializadas, pelos seus prêmios, pela sua ajuda financeira e numerosos outros favores, funcionam, na realidade, como departamentos de propaganda da principal indústria de leite em pó do país. (...) O resultado dessa situação é que a questão do leite, através da desnutrição, torna-se sério problema médicosocial do país, sendo, não raro, sua abordagem reduzida nos congressos médicos, para não constranger os industriais que "generosamente" os financiam (...). (Barbosa Filho, 1977) $)^{11}$

Nos congressos nacionais de pediatria, é prática corrente os participantes realizarem sua inscrição e suas reservas através da empresa.

Pan-Americano de Pediatria", "IV Congresso Latino-Americano de Pediatria"; "XIX Congresso Brasileiro de Pediatria", São Paulo; "Primeiro Congresso Pediátrico do Espírito Santo", Vitória etc. (Diário Oficial do Estado de São Paulo, 28 de abril de 1976, p.74).

${ }_{11}$ Um claro exemplo desse controle pode ser encontrado nos acontecimentos que "perturbaram" o Congresso de Nutrição realizado em agosto de 1977, no Hotel Nacional do Rio de Janeiro. Durante esse congresso, foi divulgado, entre os participantes, um abaixoassinado que denunciava certas práticas da Nestlé em países do Terceiro Mundo. O abaixoassinado foi retirado da circulação a pessoa responsável por sua divulgação ficou retida pelo Serviço de Segurança do Congresso durante toda a duração do encontro. 
Quanto aos conferencistas, ela se encarrega de seus honorários, assim como de vários custos acarretados pela viagem. ${ }^{12}$

A empresa é muito bem informada sobre tudo que concerne à profissão pediátrica: tem, por exemplo, uma lista completa dos médicos pediatras dos principais Estados, coisa que nem a Associação Médica tem condições de informar.

A preocupação da Nestlé em controlar - ou, pelo menos, em influenciar — os pediatras se concretiza dentro de um duplo processo: de um lado, vimos que tenta apropriar-se do conhecimento médico, influenciando os temas de ensino nas universidades, as pesquisas e os encontros científicos. De outro lado, aproveita-se do poder médico, para melhor chegar aos consumidores. São os próprios profissionais de saúde que, como prestigiosos intermediários, divulgam a ideologia da empresa de uma forma eficiente e dificilmente questionável.

Por que a Nestlé escolheu essa estratégia para difusão de seus produtos? A resposta a essa pergunta é muito simples: se a empresa se dirige a você, consumidor, através de sua propaganda clássica, e tenta persuadi-lo a comprar uma lata de leite em pó para seu filho, sua reação vai ser uma; mas se é um médico especialista, um pediatra, que lhe aconselha a mesma coisa, sua reação vai ser bem diferente. A mensagem tem um peso maior, porque passa pela aprovação da autoridade médica. A empresa usa a imagem ideológica do "médico-especialista-proprietário do conhecimento", para tentar impor seus produtos nos hábitos de consumo cotidiano. O costume de doar alimentos aos filhos de pediatras durante seu primeiro ano de vida tem, fora do objetivo de ganhar a simpatia desses pediatras, uma consequência da mesma ordem: "Se os próprios pediatras administram produtos Nestlé aos seus filhos, esses produtos devem ser bons e podemos imitá-los".

A empresa publica livretos de divulgação de regras de puericultura, que são distribuídos aos pediatras, os quais, por sua vez, podem dá-los aos seus clientes. Analisamos dois exemplares desses fascículos (Castro Filho, 1974 e 1977): nota-se que destacam o fato de terem sido escritos por um médico, mas nenhum dos dois cita a empresa como sendo seu órgão

\footnotetext{
12 Alguns anos atrás, a empresa colocava até companhia feminina à disposição dos congressistas.
}

financiador ou editor. Parecem brochuras que respondem à requerida "objetividade científica". No entanto, ambos apresentam a Nestlé como a única produtora de alimentos infantis no Brasil e dedicam $85 \%$ de suas páginas à descrição dos leites em pó e dos alimentos infantis preparados dessa empresa. Esse tipo de propaganda disfarçada tem um peso maior e provoca resultados mais importantes do que a publicidade tradicional, exatamente porque apela para a autoridade médica.

A opção da Nestlé de utilizar os médicos como intermediários em suas vendas deu resultados inegáveis. Vários estudos demonstraram a relação existente entre a "medicalização" do parto (medida pela crescente divulgação de exames pré-natais e de partos hospitalares) e a diminuição da amamentação. Vale a pena citar um desses trabalhos aqui, porque demonstra a existência dessa causalidade de uma forma aguda. Registrou a tendência gráfica do declínio do aleitamento natural numa comunidade de origem rural, durante 25 anos, e constatou um aumento inesperado dessa atividade durante o biênio 1967-1968. Essa época coincide exatamente com o fechamento do único hospital da cidade (Campos Júnior, 1978)!

\section{A Nestlé e as mães}

Receosa de críticas, a Nestlé é bastante discreta e sutil nos folhetos que distribui nas maternidades brasileiras. A propaganda para seus leites em pó e alimentos infantis é integrada dentro de uma vasta campanha para difusão de métodos modernos de tratamento das crianças. Em Cuide bem de mim. Como cuidar do bebê nos seus primeiros 12 meses de vida, por exemplo, uma brochura editada pela empresa e distribuída em maternidades, não faz uma propaganda direta e exclusiva para os produtos que coloca no mercado: a alimentação do neném é somente um dos temas abordados. O livreto traz numerosas informações sobre aspectos de puericultura moderna. Parece ter sido escrito para crianças de uma sociedade ocidental muito desenvolvida: as recomendações de higiene do bebê e de limpeza do seu meio ambiente não correspondem, de maneira alguma, às condições da maioria da população brasileira.

Graças às ilustrações de folhetos desse tipo, à sua propaganda e a suas atraentes embalagens, a empresa provoca, nas mães das várias classes da sociedade, uma associação entre um rosto de neném feliz, sadio e rico, e 
as latas de produtos infantis Nestlé. As mães de famílias pobres aprendem (como empregadas domésticas, por exemplo) que as mães de classe média e alta - que também querem dar "o melhor" para seus filhos e são mais "informadas" que elas - usam mamadeira e leite em pó. São levadas, assim, através da propaganda da empresa e da imitação dos costumes da classe dominante, a desvalorizar o leite materno e a adotar métodos "modernos", que exigem sua integração dentro do sistema capitalista de distribuição e de consumo.

Vimos que a propaganda feita pela Nestlé nas maternidades brasileiras faz parte de uma campanha mais vasta de conselhos dirigidos às mães. A empresa participa ativamente da difusão de regras de uma puericultura moderna mais adaptada à sociedade de consumo.

Em lugar de valorizar os métodos que reforçariam a autonomia das classes populares em relação ao mundo do consumo, os programas de saúde pública deixam a iniciativa ao setor privado. Este elogia os princípios de uma puericultura ocidental consumista, esperando que, uma vez aceitos tais princípios, isso provocará um aumento no consumo dos produtos que coloca no mercado. ${ }^{13}$

\section{As instituições de saúde}

O ambiente dos serviços brasileiros de saúde já foi mencionado como podendo inibir o reflexo de lactação das mães. Um aspecto essencial desse problema reside no modelo organizacional das maternidades em torno de berçários, copiado da situação tradicionalmente encontrada nos EUA. Segundo esse modelo, os recém-nascidos são separados de sua mãe logo depois do parto e levados para um berçário, onde serão entregues aos cuidados de enfermeiras. Cada uma delas é encarregada de 20 a 30 crianças, e lhes dará automaticamente a mamadeira, antes que sejam levadas até as mães, e sem o consentimento prévio destas últimas. É uma fácil solução encontrada pelos hospitais para diminuir os — segundo eles - inúteis vaivéns entre o berçário e os quartos das mães. Permite diminuir o número de

${ }^{13}$ Esse fenômeno foi analisado como um dos aspectos do processo de expropriação dos meios de sobrevivência autônoma das classes populares em Veiga (1976). Existem alguns programas oficiais de incentivo à amamentação materna, porém, em face dos recursos aplicados pela Nestlé esse esforço parece ser ainda bastante marginal e descontínuo. enfermeiras e, por conseguinte, os custos de funcionamento do hospital. Alimentadas com leite em pó, as crianças ficam mais rapidamente saciadas. Seu tempo de digestão é maior do que se tivessem ingerido leite materno e elas, consequentemente, dormem mais, o que garante maior tranquilidade às enfermeiras.

A separação entre mãe e filho dura 12, 24 ou 48 horas, segundo o regulamento interno da maternidade. Habitualmente, a entrada das mães no berçário é proibida e elas somente poderão dar a primeira mamada depois desse período. Isso influenciará negativamente seu reflexo de lactação, assim como o reflexo de sucção das crianças, já acostumadas, nessa altura, ao uso da mamadeira.

Essa separação brutal não é nociva apenas do ponto de vista da amamentação: quando consideramos os processos emocionais que ligam a mãe ao seu filho, a importância de sua proximidade física no pós-parto é essencial. Constatações médicas recentes confirmam que a proximidade pós-natal mãe-filho não somente facilita a amamentação, mas também diminui grande parte das ansiedades, e inseguranças futuras da mãe frente aos cuidados que deverá administrar à criança. Tal proximidade leva a um relacionamento mais calmo e instintivo (Klaus e Kennell, 1978).

\subsubsection{Interesses econômicos e missão humanitária}

Da mesma forma como a Nestlé se orgulha de sua "tarefa pediátrica", apresenta uma grande preocupação em provar seu impacto econômico e humanitário nos países em que atua. Grande parte de seu discurso é orientado para a justificação de seu comportamento comercial, como correspondendo a interesses que seriam comuns à população e à própria empresa.

Tentar-se-á retratar alguns aspectos desse discurso, que revelam um conjunto de valores a que a empresa recorre de maneira sistemática, para justificar-se e convencer o público de sua utilidade. ${ }^{14}$ Para isso, serão ${ }^{14}$ Não se pretende chegar, neste trabalho, a um estudo exaustivo do problema, uma vez que
isso suporia um instrumental metodológico mais completo, do qual a autora não dispõe
agora, nem do ponto de vista da análise ideológica, nem do da análise estritamente
linguística. Limita-se a oferecer certo material descritivo, resultante de algumas observações 
analisados a seguir alguns trechos de "mensagens" divulgadas pela Nestlé: artigos publicados em seu nome, ou a seu respeito, durante os últimos 15 anos (entrevistas com diretores da empresa, relatórios de atividades etc.) e que têm como objetivo declarado a "informação" do público. ${ }^{15}$

Num folheto de divulgação, em que o grupo suíço desenvolve esse tema da comunidade de interesses, ele o formulou da seguinte maneira:

A Nestlé não é uma sociedade filantrópica e suas atividades não consistem em 'levar ajuda' aos países não-industrializados. Ocorre, no entanto, que a própria natureza das atividades da empresa nesses países - transformar lá mesmo uma matéria-prima que ela se esforça por aumentar em quantidade e qualidade - é um fator de desenvolvimento econômico. Nós nos encontramos, portanto, em presença de uma comunidade de interesses na qual o progresso de uma das partes gera imediatamente uma melhoria para a outra. (Nestlé, 1975)

É inegável que, em um primeiro momento, a Nestlé incentivou muito a produção de leite em todas as regiões em que se implantou no Brasil. Esse aumento da produção de leite, no entanto, não implica necessariamente uma melhoria nas condições de vida dos produtores dessas regiões: eles formam um interlocutor extremamente fracionado para a empresa, e foram subordinados a ela em vários aspectos.

O holding suíço encaminha, na citação anterior, o tema de uma ideologia econômica e política mais vasta, de molde desenvolvimentista: "uma melhoria da produção levaria necessariamente a vantagens imediatas para o país", sem que sejam mencionados os aspectos essenciais da distribuição e do consumo dentro desse país.

Encontramos, em um pequeno artigo intitulado "Exemplo para as demais", vários aspectos constantes do discurso da empresa. Escrito para o

de caráter quase intuitivo. Elas contêm, sem dúvida, a indicação de certas temáticas que poderão ser aprofundadas em estudos posteriores.

${ }^{15}$ Para facilitar a exposição, são citados fragmentos selecionados. A autora está consciente das limitações inerentes a essa metodologia de trabalho: citações, retiradas do seu contexto, podem ser interpretadas de maneira polissêmica e manipuladas para provar qualquer coisa. No entanto, essa metodologia pareceu a única possível no quadro deste estudo, pressupondose, evidentemente, que os fragmentos escolhidos reflitam um certo sentido contido na unidade do texto original do qual foram extraídos.
Suplemento Agropecuário do diário Estado de Minas, de 11 de janeiro de 1975, e dirigido, pois, para um público de fazendeiros, o artigo tem objetivo de divulgação. Sua compreensão é fácil, de modo que a leitura das mensagens se realiza sem obstáculos.

O fundador da empresa, Henri Nestlé, é apresentado como cientista humanista, mais do que como homem de negócios:

(...) na cidade suíça de Vevey, no ano de 1886. Um químico se entregava, naquela época, a pesquisas alimentares. Possuía grande paixão pelas experiências e muita criatividade. Embora não houvesse no século XIX tanta carência de produtos alimentares, como a que hoje avassala a humanidade, suas pesquisas se dirigiam para o aperfeiçoamento de alimentos necessários a salvaguardar vidas humanas mais frágeis e ajudá-las a se desenvolverem sadiamente. Ao perseguir esse objetivo, descobriu a fórmula de uma farinha composta que foi imediatamente utilizada para alimentar crianças com falta de assimilação. Esse novo alimento correspondeu plenamente e muitas vidas infantis foram salvas. Henri Nestlé era o nome deste químico abnegado, que depositava em seu trabalho de pesquisador muito amor e carinho.

Outra constante é a colocação do problema nutricional brasileiro como uma das razões fundamentais que motivaram a empresa a investir no país:

Em 1921,0 Brasil, com sua extensão continental, era um país que dependia da importação de quase todos os produtos, principalmente os destinados à alimentação. Era, realmente, um período difícil na vida dos brasileiros. Sérios problemas de nutrição elevavam os índices de mortalidade infantil. Sentindo o problema brasileiro e vendo as boas perspectivas de mercado, uniu o útil ao agradável, e, nesse ano de 1921, na cidade de Araras, em São Paulo, foi instalado o primeiro centro industrial do grande complexo empresarial suíço.

Uma vez que o artigo foi escrito para agricultores, a maior parte dele é dedicado à descrição das excelentes relações que unem a empresa e seus fornecedores. Baseando-se nessa descrição e no aspecto nutricional mencionado anteriormente, o autor conclui:

A Nestlé não pertence às chamadas 'empresas multinacionais', cujas atuações são discutidas e discutíveis. Onde finca suas raízes, os benefícios saltam à vista. 


\section{Empresa humana}

As firmas alimentícias têm uma importante vantagem em relação a empresas de outros setores industriais: em termos de propaganda, podem enfatizar sua "luta contra a fome", utilizando imagens comoventes de criancinhas subnutridas. Nesse sentido, a Nestlé fala da responsabilidade que assumiu perante a comunidade:

Mais que um simples trabalho, a indústria alimentar tem uma elevada missão a cumprir. ${ }^{16}$

Numa entrevista à revista francesa Entreprise, o presidente da matriz suíça diz o seguinte:

(...) somos muito sensíveis ao nosso papel de serviço público. Nós nos esforçamos em fabricar alimentos de primeira necessidade, entre outros alimentos infantis. Isso nos leva muitas vezes a investir sem nos preocuparmos em ganhar dinheiro, pelo menos numa primeira etapa: é absolutamente impossível para nós parar a fabricação de um produto que responde a uma necessidade fundamental sob o pretexto de que ele não seja rentável. Não podemos enriquecer-nos com a pobreza dos outros! ${ }^{17}$

É muito importante para a Nestlé conseguir impor essa imagem de "empresa humana". No mesmo artigo, interrogado sobre os possíveis perigos do "gigantismo" do grupo suíço, o presidente da empresa continua:

Não vejo absolutamente como o tamanho constitui um obstáculo. Quando alguém me faz essa pergunta, eu respondo: "Em que e a quem estamos prejudicando? Não seria ao contrário uma garantia de qualidade para o consumidor, uma garantia de seriedade que ele não teria comprando um produto fabricado por alguém que não é conhecido? Uma grande sociedade não se pode permitir errar gravemente e menos ainda errar durante muito tempo! Não é assim que a concentração das fabricações permite obter preços de custo e preços de venda muito mais vantajosos? Enfim, como pretender que os grupos internacionais sejam os lobbies? Contrariamente ao que se poderia crer, somos muito menos poderosos que muitos grupos de interesse. Não temos nem força política nem força eleitoral e não podemos evidentemente nos entregar a violências".

\footnotetext{
${ }_{17}^{16}$ J.P. Brulhart, diretor-presidente da Cicobra/Nestlé, em Atualidades Nestlé no 50, 177, p.5.

${ }^{17}$ Entreprise, $\mathrm{n}^{\mathrm{o}} 821,5$ de junho de 1971, pp.38-49.
}

Não é fácil aproximar e combinar dois termos que, habitualmente, são vistos como excludentes ("gigantismo" e "empresa humana"). No entanto, apesar de parecerem combater-se reciprocamente, dentro do discurso da empresa, eles brilham por sua concordância. No nosso caso, o entrevistado não respondeu à pergunta que lhe foi feita (uma pergunta que tratava de poder econômico) e seguiu um duplo raciocínio:

1) para o consumidor, o tamanho da empresa é uma garantia de qualidade e de baixos preços;

2) quem representa o verdadeiro perigo e deve ser combatido são esses "grupos de interesse" a que faz alusão: os lobbies... os sindicatos de trabalhadores que têm força política e recorrem à "violência", para impor suas exigências...

A interpretação do leitor, forçando sua identidade com a figura do consumidor, é uma técnica muito utilizada para justificar situações polêmicas. Encontramos o mesmo argumento, por exemplo, num artigo escrito em defesa do grupo suíço em um contexto diferente: responde à acusação de que a empresa eliminaria pequenas indústrias regionais de laticínios e transformaria seus fornecedores de leite em quase empregados.

(...) Porque não podemos esquecer que não existem apenas a Nestlé e o produtor ou fornecedor. Existe também o povo, o consumidor. Formam trilogia. E na cooperação, no bom entendimento entre os três, repousa o progresso de uma sociedade livre e civilizada. ${ }^{18}$

Nesse artigo, dirigido aos produtores (ele é intitulado "Sr. produtor e fornecedor de leite"), o autor tenta camuflar a contradição existente entre a empresa e seus fornecedores, introduzindo um terceiro elemento mediador: o povo, os consumidores. E o aparecimento desse terceiro personagem, que engloba tanto o primeiro quanto o segundo, muda a natureza do conflito; de conflito de classe, ele se torna simples desentendimento entre pessoas, que,

${ }^{18}$ E, em outro trecho: “(...) Duvidamos apenas de uma coisa (falamos como povo, como consumidor, repetimos): estariam esses subprodutos do leite por melhores preços, isto é, mais baixos, caso não existisse na região uma grande fábrica de laticínios? A situação de antigamente (anterior à Nestlé) era melhor que a de hoje, isso levando em conta o poder aquisitivo daquela época? Não estamos defendendo a Nestlé, nem os produtores; raciocinamos apenas como consumidores". ("Sr. produtor e fornecedor de leite", in Voz do Rio Verde, jornal local da cidade de Três Corações (MG), 2 de junho de 1963. Grifos da autora.) 
no fundo, têm interesses comuns. A todos importa que as mercadorias cheguem ao mercado consumidor ao menor preço possível!

No entanto, nos dois trechos citados, os autores se "esquecem" de dizer que o setor da alimentação no Brasil é muito concentrado. Não é possível continuar a considerar a concorrência como quadro de referência, e ignorar que vários monopólios ou quase-monopólios são responsáveis por uma parte importante da produção, e capazes de controlar seu volume e seu preço.

\section{Empresa familiar}

Nesses dois artigos, a Nestlé se defende apelando para o interesse dos consumidores. Existem outros meios de "fazer esquecer" seu caráter transnacional e seu gigantismo. Um deles é facilmente encontrável em suas propagandas. Na ocasião de seu quinquagésimo aniversário, em 1971, a filial brasileira do grupo publicou uma brochura intitulada Cinquenta anos de uma presença familiar. E, desde então, essa presença familiar acompanha a marca Nestlé como um epíteto próprio. Encontramo-lo nas propagandas da empresa e nos artigos escritos sobre ela. E perguntamo-nos: por que essa visível predileção da Nestlé por essa fórmula?

A explicação pode ser procurada na dupla significação da palavra "familiar". Sendo uma presença familiar, significa, evidentemente, que a empresa é conhecida por todos os brasileiros, está presente em sua vida cotidiana. Mas, ao lado desse conteúdo manifesto da frase, existe outro, latente, que tem a ver com o segundo significado do significante "familiar". Nesse sentido, quando a Nestlé pretende ser uma empresa familiar, escolhe uma fórmula que sugere a realidade mais distante possível de uma superpoderosa e perigosa empresa transnacional. Pode ser uma forma de despreocupar o público a seu respeito, provocando, em sua imaginação, imagens que associam com a palavra "família": tamanho pequeno, ausência de perigo, segurança emocional, confiabilidade etc. Nada disso é explícito. Tudo fica no domínio do não-dito e das associações inconscientes.

O próprio diretor-presidente do grupo no Brasil gosta de se referir aos empregados e trabalhadores da empresa como formando Uma grande família, a "grande família" da empresa. (Atualidades Nestlé, no 50, 1977, p. 5) Ele recorre, nesse caso, a uma técnica bastante utilizada pela classe no poder quando trata, por exemplo, da "família brasileira" e mascara, dessa maneira, os conflitos de classe existentes dentro da sociedade.

\section{A "mãe-Nestlé", "babá do Brasil"}

Fora do símbolo da família, existe outro, bastante utilizado pela empresa na sua apresentação ao público: o da maternidade. $E$ isso mesmo que se pode ver em um texto publicado na Banas, revista de conteúdo econômico-financeiro dirigida a empresários. O texto citado faz parte da introdução a uma entrevista com o diretor-geral da filial brasileira do grupo suíço, publicada com o seguinte título: "Nestlé: a babá de 50 anos" e que trata da situação da indústria alimentícia no país e das perspectivas comerciais da empresa. Escreve, a propósito, o jornalista:

O seu nome mesmo é Nestlé, a babá de todos os brasileiros, de 0 a 100 anos. Sua missão tem sido a de cuidar da comida que é saúde. E nisso ela vai ainda mais longe, fazendo um trabalho de mãe pra filho. Começou como ama-de-leite, só cuidando do nosso leitinho. Mas o Brasil cresceu e ela teve de tratar também da gente grande produzindo chocolate, sopinhas e, agora, supergelados $(. . .)^{19}$

Esse estilo infantilizado e sentimental, que nada tem a ver com a forma em que se concebem habitualmente os artigos da Banas, justifica-se unicamente pelo tipo de produto que a empresa coloca no mercado: alimentos infantis. Fica explícito que ela tem uma "missão" e que sua relação com os brasileiros ("todos os brasileiros de 0 a 100 anos", sem exceção, nem diferença de classe) é de "mãe pra filho".

$\mathrm{O}$ que significa essa mensagem, que identifica a empresa com a imagem da mãe? A maternidade é sinônimo de amor, abnegação no trabalho e sacrifício sem esperança de retribuição. A mãe (figura particularmente valorizada numa cultura predominantemente latina), e, portanto, a "Mãe-Nestlé", deve gerar, nos filhos, um amor correspondente e uma gratidão sem limites.

Observando a estrutura do artigo de que faz parte a citação, vemos que o leitor, antes de poder ler a entrevista com o diretor-geral da empresa é submetido a uma introdução e não pode escapar à sua mensagem ("Nestlé

\footnotetext{
${ }^{19}$ Banas, $1^{\circ}$ de novembro de 1971 , pp.12-16
} 
= Mãe"). Antes de passar à leitura de tendências econômicas, expressas em dados estatísticos, quadros e gráficos, ele deve impregnar-se da ideia do amor materno que o grupo suíço sente em relação ao povo brasileiro e de sua missão filantrópica: primeiro vem a mensagem sentimental e ideológica, e depois "os negócios".

Até em artigos "informativos", como acabamos de ver, encontramos referências a certos motivos inconscientes de força insuspeitável (os temas da família e da maternidade): são esses mesmos motivos que impregnam, também, a publicidade visual e escrita da empresa, tal como veremos na próxima parte deste trabalho.

\subsection{Publicidade: análise de alguns mecanismos utilizados}

A preocupação da empresa com sua propaganda é constante. É muito difícil conseguir dados globais sobre esse aspecto de sua estratégia de vendas, porque são absolutamente confidenciais. Informações parciais, no entanto, puderam ser coletadas. A mais significativa delas se refere à editora Abril Cultural. Verificou-se, em 1973, que a Nestlé foi o maior anunciante daquela editora durante os anos anteriores, tendo investido, para publicidade em revistas da Abril Cultural, o equivalente a $\operatorname{Cr} \$ 1,5$ milhão, em 1971, e a Cr\$2,3 milhões, em 1972. Isso dá uma certa ideia da importância da publicidade da empresa, quando se sabe que sua promoção em revistas ainda é completada através de outros meios de comunicação, tais como a televisão e os cartazes na rua ou em pontos de venda (outdoors).

A publicidade referente ao produto que decidimos estudar aqui, o leite em pó para uso infantil, é promovida quase que exclusivamente dentro das maternidades e dos consultórios pediátricos. Este estudo seria incompleto, porém, se não abordasse certas mensagens publicitárias mais amplas, dirigidas ao público em geral. Foram escolhidos, pois, para análise, três anúncios publicitários que não se restringem a nenhum produto da empresa, mas em que ela se apresenta ao público falando de si mesma.

$\mathrm{Na}$ medida em que não se preocupa em descrever as qualidades de produtos específicos, evidencia, com maior clareza, sua interpretação do mundo. A ideologia em que está baseada - e que, ao mesmo tempo, quer difundir — aparece, de maneira mais clara, nessas imagens de mulher grávida ou de mãos dadas exibindo sua aliança, do que se representassem uma lata de leite em pó ou de leite condensado. O produto é envolvido numa rede de evocações emocionais e simbólicas fortemente carregadas, que reenviam ao inconsciente individual de cada leitor. Por outro lado, a publicidade favorece e reforça a absorção espontânea dos valores sociais dominantes.

Observemos os três anúncios publicitários selecionados, levando em conta seu caráter específico. Como mensagem tipicamente publicitária, evocam unicamente o que consideram ser essencial e negligenciam (ocultam) o resto. Elas operam um tipo de metonímia, apresentando uma parte da realidade como sendo o todo.

Vamos analisar, um por um, os elementos que a Nestlé achou importante destacar. Um indicador simples dessa importância é a ocorrência quantitativa de certas palavras nos textos. Vemos, por exemplo, que o termochave que serve de eixo central a essas propagandas é a palavra "vida". Encontramo-la 17 vezes, seja de maneira pura, seja sob várias formas do verbo viver. Chegamos a esse termo, carregado de forte conotação afetiva, através de outro grupo de palavras mais neutras: as que giram em torno dos termos "nutrição" e "alimentação" (essas palavras, ou outras formadas a partir da mesma raiz, aparecem no texto publicitário 22 vezes).

A linha lógica que se mantém nas três propagandas começa e termina com a imagem da vida, passando pelos produtos Nestlé, a alimentação e a saúde. "Os produtos Nestlé são fontes de vida" (propaganda $n^{\circ} 2$ ): voltamos à já abordada imagem da mãe. É sempre o mesmo símbolo que volta, sob formas ou aspectos um pouco diferentes. A repetição frequente dessas duas palavras ("Nestlé" e "vida") tem, como objetivo, a criação de um mecanismo associativo inconsciente no público. Encontra-se, aqui, novamente um processo de tipo metonímico, que apresenta uma parte da realidade como sendo o todo. Os produtos Nestlé não representam nada mais que uma das possiveis maneiras de se alimentar. A alimentação é um dos elementos que determinam o estado de saúde. A saúde entra em conta quando se trata de perpetuar a vida. Não existe, logicamente, nenhuma relação linear entre a Nestlé e a vida.

O estilo utilizado reforça ainda essa confusão: é um estilo de livres associações, de frases curtas, tocantes e desconexas, que não analisam 
fenômenos de causa e efeito. O pensamento é decomposto numa enumeração de fragmentos heteróclitos, que levam a um raciocínio brusco e inusitado. Exemplo:

\section{Propaganda $\mathrm{n}^{\mathrm{o}} 1$}

\section{OLHA QUE COISA MAIS LINDA}

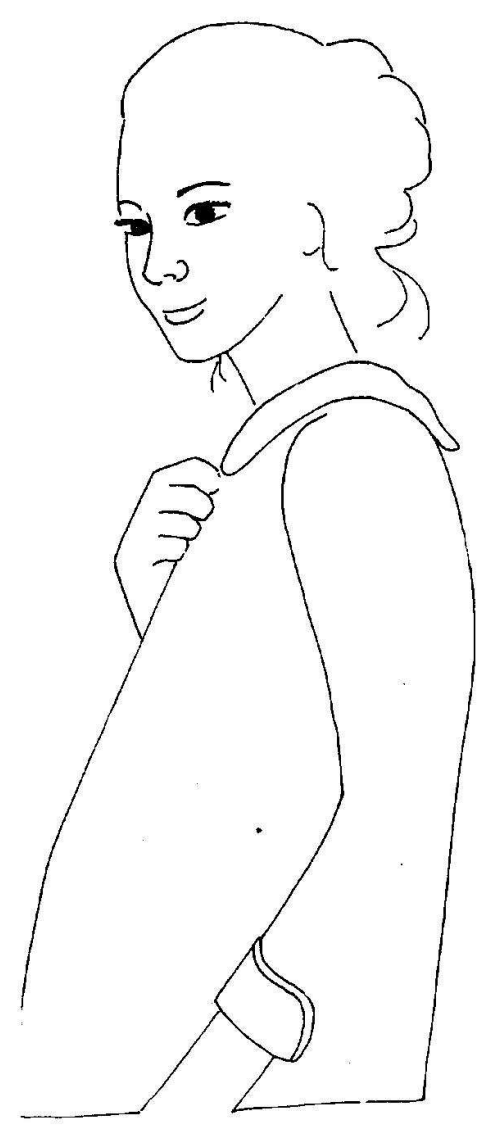

Nascer, crescer, viver. Verbos familiares, de todos os dias. Nas maternidades, nas escolas, pela vida afora.

Os produtos Nestlé são também uma presença familiar, de todos os dias. Eles alimentam quem nasce, fortalecem quem cresce, nutrem quem

Para que a vida se faça e se desenvolva e se prolongue sempre com mais saúde, força e beleza, veja quanta coisa se faz

Pesquisas para o desenvolvimento de novos produtos: nutritivos, saudáveis, gostosos.

Constante esforço na introdução de novas técnicas, novas ideias, novos conceitos alimentares.

Convênios com entidades direta ou indiretamente ligadas à melhoria da alimentação.

Programas de trabalho junto a médicos pediatras e nutricionistas, incluindo cursos e recursos para estudos.

Ajuda às donas-de-casa, num ininterrupto trabalho de pesquisa na combinação de alimentos (novas receitas, modos de preparo).

Entre inúmeras outras áreas de atuação, as acima citadas representam a contribuição dos produtos Nestlé à tarefa diária de elevar sempre mais os padrões alimentares da gente brasileira. linda?

Nascer, crescer, viver. Existe coisa mais

Produtos Nestlé

Uma presença familiar

Companhia Industrial e Comercial Brasileira de Produtos Alimentares

Fonte: Boletim do Leite, $\mathrm{n}^{\circ}$ 577, novembro de 1976, p. 31

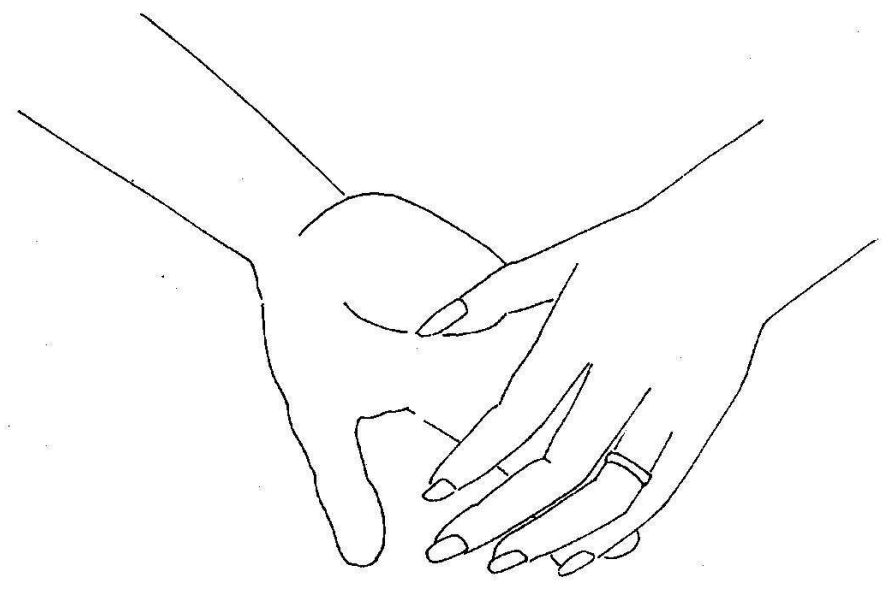

AS FONTES DA VIDA

O cordão umbilical, entre filho e mãe. O tubo respiratório, entre astronauta e cápsula. As mãos dadas, entre homem e mulher. Água, ar, amor.

Uma fonte de vida deve manter o homem: vivo, saudável, forte, produtivo, dinâmico.

Os produtos Nestlé são fontes de vida. Porque, entre as fontes primeiras (as matérias-primas) e a vida propriamente dita (você, seus filhos), realizam o trabalho de enriquecer, combinar, desenvolver e distribuir alimentos.

Uma imensa comunidade trabalha diariamente para conduzir o leite natural através dos caminhos que o levam até a lata de leite em pó, nutritivo e prático. São os caminhos da confiança, da qualidade.

Especialistas trabalham na elaboração e no desenvolvimento de novas fontes de vida. Em cada fábrica, um laboratório. Nossos técnicos estão sempre pesquisando e ensinando a respeito da melhoria de rebanhos e pastagens, silos e vacinações. Estudando uma vida sempre nova.

Ontem, leite condensado e em pó, farinhas enriquecidas, bebidas achocolatadas, café solúvel, caldos e sopas desidratadas, de preparo imediato.

Hoje, os alimentos infantis, à base de legumes, carnes e frutas, prontos para servir. Amanhã, novos produtos Nestlé.

Fica dito: da fonte à vida, produzindo fontes de vida.

Produtos Nestlé

Uma presença familiar

Companhia Industrial e Comercial Brasileira de Produtos Alimentares

Fonte: Brasil industrial, Banas, 1977-78. 


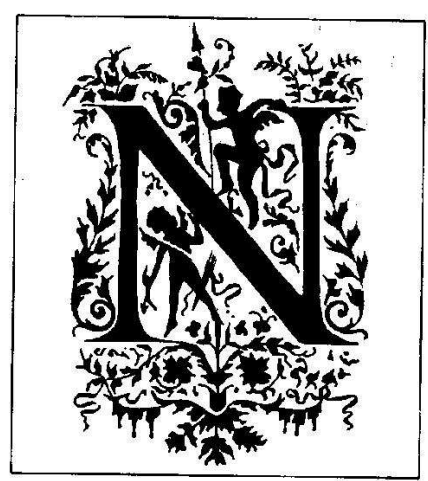

NINHO

Habitação das aves, para criação dos filhos. Abrigo, casa paterna (Pequeno dicionário brasileiro da língua portuguesa). Marca registrada (Nestlé) por uma empresa com intuitos bastante semelhantes, posto que dedicada à alimentação, às fontes da vida.

\section{NOVO}

Palavra da família das dinâmicas. Como agora, hoje, vida. Qualifica filosofia de operação de empresa que mantém as tradições de suas origens com o oxigênio da imaginação. Produtos Nestlé, por exemplo.

\section{NATUREZA}

Nossa matéria-prima. Nossa musa inspiradora e rima rica de nossos versos.

Dela vêm nossos produtos, que mantêm sempre a mesma certeza de poder nutritivo.

\section{NESTLÉ}

Nome próprio, enquanto nome de um químico que em 1866 encontrou a solução de um grave problema alimentar, ao salvar a vida de uma criança, lançando assim as bases da indústria de alimentação infantil. Nome comum, porque hoje, mais de um século depois, está em milhões de casas em todo o mundo, presença familiar

\section{Produtos Nestlé}

Uma presença familiar

Companhia Industrial e Comercial Brasileira de Produtos Alimentares

Fonte: Boletim do Leite, $\mathrm{n}^{\circ}$ 570, abril de 1976, p. 5.
O cordão umbilical, entre filho e mãe. O tubo respiratório, entre astronauta e cápsula. As mãos dadas, entre homem e mulher. Água, ar, amor.

Uma fonte de vida deve manter o homem vivo, saudável, forte, produtivo, dinâmico.

Os produtos Nestlé são fontes de vida. Porque, entre as fontes primeiras (as matérias-primas) e a vida propriamente dita (você, seus filhos), realizam o trabalho de enriquecer, combinar, desenvolver e distribuir alimentos.

(...) Fica dito: da fonte à vida, produzindo fontes de vida. (propaganda $\mathrm{n}^{\circ} 2$ ).

Nos três anúncios (e isso aparece mais claramente ainda no último, que é concebido como uma página de dicionário), notamos que a empresa não tenta apresentar-se através de raciocínios lineares, que dificilmente poderiam chegar à identidade "Nestlé = vida". Ao contrário, ela baseia sua estratégia publicitária em um discurso de "livres" associações, que tocam os leitores de uma forma não-racional, mas não menos profunda. Ela dirige seu discurso diretamente ao inconsciente de seu público, tentando exprimir-se na linguagem própria a esse inconsciente. ${ }^{20}$

A relação da Nestlé com o símbolo escolhido, a "vida", não aparece isolada. Ela se integra num elaborado complexo de relações que a empresa mantém com o mundo e as coisas. E é esse "todo" de representações, ideias e valores que vai determinar a maneira pela qual os representantes da Nestlé vão falar da "vida", interpretando a realidade e refletindo sua visão global do mundo.

Um primeiro tipo de valores que a empresa achou importante destacar, em seu discurso, são os que já foram mencionados várias vezes, e que podem ser chamados de "familiares" e "maternais". Na ideologia do grupo suíço, a existência da família é um ponto de referência fundamental. Não é uma casualidade o fato de que, como marca registrada, a empresa tenha escolhido um desenho representando um ninho de passarinhos, os pais alimentando os filhotes. Não é uma casualidade o fato de que a Nestlé

${ }^{20}$ É essa relação entre publicidade e inconsciente que permite aplicar, em análises publicitárias, o instrumental dos conceitos psicanalíticos, tais como simbolização, ambivalência, condensação etc. (Bardin, 1977). 
utiliza tanto o lema "uma presença familiar", para se apresentar ao público. Para ela, as "fontes da vida" estão ligadas ao matrimônio e à família, às mãos dadas com sua aliança (propaganda $n^{\circ} 2$ ). A empresa recupera os valores da ideologia dominante, apresentando, em seu discurso, argumentos de autoridade indiscutível.

Nesse contexto, é importante citar a preocupação da empresa com o programa de ensino de Educação Moral e Cívica nas escolas brasileiras. Para comemorar "50 anos de uma presença familiar", distribuiu, em 1972, 72 mil conjuntos de murais didáticos em escolas de primeiro grau, junto com Um Manual do Professor, dando sugestões para o aproveitamento das ilustrações. Entre estas, figuram "Deus e a família", "Bandeira nacional", "O futuro do Brasil" etc. ${ }^{21}$ Vemos como, ao usar a mensagem de "Deus", "família", "pátria", a empresa se fortifica, mas também está reforçando essas imagens-chaves da ideologia dominante.

Mas voltemos aos nossos anúncios. Podemos perguntar a nós mesmos o que evocam essas imagens de mulher grávida, mãos ligadas, ninho de passarinhos, vacas no pasto. Quais são os elementos comuns nessas frases que falam de um homem que salvou a vida de uma criança, de cordão umbilical, maternidade, escolas, natureza, casa paterna, abrigo etc.? Esses símbolos podem provocar reações afetivas individuais diversas, mas, mesmo assim, carregam uma certa conotação geral que dificilmente pode ser negada. Evocam situações de quietude, intimidade e harmonia familiar, felicidade de crianças: estas seriam as aspirações dos consumidores potenciais, aspirações com as quais a empresa espera que eles se identifiquem para que se tornem receptivos a outros aspectos de sua mensagem publicitária.

O segundo tipo de valores que chama atenção nos anúncios analisados é o que trata da seriedade profissional da empresa: esta quer ser vista como preocupada, acima de tudo, com a qualidade e a ininterrupta melhoria de seus produtos. Para isso, seus "especialistas" e "técnicos" fazem "pesquisas para o desenvolvimento de novos produtos", num "constante esforço na introdução de novas técnicas" e "num ininterrupto trabalho de pesquisa na combinação de alimentos" Essa apresentação da empresa como interessada prioritariamente na qualidade de seus produtos,

\footnotetext{
${ }^{21}$ Exame, junho de 1972
}

já aceita e interiorizada por grande parte dos consumidores brasileiros, permite-lhe pedir um preço mais alto que o de seus concorrentes para qualquer alimento que coloca no mercado.

Para desenvolver essa reputação de "seriedade", o grupo suíço tenta combinar dois termos contraditórios: o dinamismo e a tradição, ou, para citar as próprias palavras da empresa, ela apresentaria uma "filosofia de operação (...) que mantém as tradições de suas origens como o oxigênio da imaginação" (propaganda n ${ }^{\circ} 3$ ). As referências à novidade, ao moderno, são importantes para captar a atenção do leitor e provocar sua curiosidade. No entanto, aqui, esses elementos são temperados por outros, relativos à tradição e à experiência, os quais deveriam garantir a confiança dos consumidores. A novidade e a tradição, à primeira vista, deveriam excluirse mutuamente. No discurso publicitário, porém, o acasalamento de valores contraditórios desse tipo é um meio de persuasão muito utilizado. Bardin (1977) mostra que esse mecanismo provoca um alívio psicológico no público, frente às tensões provocadas pelas contradições da realidade. $\mathrm{O}$ produto seria apresentado como um reconciliador, uma síntese, entre elementos opostos. Conseguiria, assim, resolver o problema da ambivalência do desejo.

Outro exemplo dessa técnica pode ser encontrado na oposição existente entre a natureza bucólica (as vaquinhas, os pássaros, a inocência da infância) e as referências feitas a tecnologias sofisticadas (cápsula espacial, pesquisas de cientistas em laboratórios, vacinações etc.).

Apesar de tratar detalhadamente da "criação" de alimentos, os processos objetivos de produção e de mercado são pouco abordados. O mundo real da produção é representado de maneira vaga. Quando se fala em produção, é uma produção abstrata (a Nestlé produz "fontes de vida"). Nos raros momentos em que a produção é abordada de maneira mais concreta ("uma imensa comunidade trabalha diariamente para conduzir o leite natural através dos caminhos que levam até a lata de leite em pó" propaganda $n^{\circ} 2$ ), segue logo uma imagem que volta ao plano da abstração: "são os caminhos da confiança, da qualidade". A empresa utiliza, também, uma linguagem ambígua quando trata da colocação de seus produtos no mercado: fala em "distribuir" (e não vender) alimentos (propaganda $\mathrm{n}^{\circ} 2$ ). Deixa de mencionar a sociedade real e suas contradições. Tanto ao nível da produção, ("uma imensa comunidade") quanto do consumo ("100 milhões 
de brasileiros"), a Nestlé pressupõe a existência de um "coletivo geral", formado de interesses individuais idênticos. ${ }^{22}$

Do ponto de vista estilístico, observamos que a linguagem dos anúncios é muito repetitiva, chegando quase a formar uma verdadeira litania. Faz um uso abundante dos artifícios retóricos mais conhecidos, tais como rima, ritmo e melodia (exemplo: "Água, ar, amor", "Nascer, crescer, viver", "Ontem (...), Hoje (...), Amanhã (...)", "A mesma pureza, a mesma certeza", "Nome próprio (...), Nome comum (...)" etc.). O modo de expressão é frequentemente figurativo, simbólico, baseado nos vários significados contidos num mesmo significante, o que pode levar a evocativos jogos de palavras ("Da fonte à vida, produzindo fontes de vida").

Como conclusão, pode-se voltar aqui à técnica de persuasão que mais chamou atenção: a utilização constante de palavras de grande poder emocional e interpelativo, que evocam sentimentos ligados à maternidade $\mathrm{e}$ à harmonia familiar. ${ }^{23}$ Tais imagens são associadas a outras, que se pretendem mais "objetivas" e contêm informações sobre as atividades do grupo suíço como empresa alimentar. Os anúncios misturam constantemente vários níveis do discurso: são confundidos o nível da informação, que deveria "falar" à razão dos consumidores, e o nível de seus valores pessoais, que interpelam diretamente suas emoções. Essa confusão entre informação e emoção acaba provocando uma extensão subliminar das qualidades da mulher grávida ou do casal com aliança aos alimentos promovidos. Quem compra produtos Nestlé compraria, ao mesmo tempo (mas a nível inconsciente, é claro), a seriedade profissional da empresa, o amor materno e a segurança familiar que acompanham os alimentos como brinde.

22 Trata-se de um mecanismo já mencionado anteriormente, na análise de artigos "informativos" sobre a empresa.

${ }^{23}$ É bom lembrar, aqui, as observações de L. Althusser sobre a capacidade da ideologia de interpelar os indivíduos como sujeitos. Na publicidade, esse fenômeno é particularmente claro, até no estilo utilizado (forma imperativa dos verbos, uso da palavra "você", imagens de personagens de frente, que dirigem diretamente a palavra ao consumidor etc.)

\section{Conclusão}

Ficou claro, ao longo do texto precedente, que a Nestlé possui um amplo poder de influência sobre o setor leiteiro como um todo: conseguiu mudar vários aspectos desse setor, ao longo dos anos, em função de suas próprias necessidades de acumulação de capital. Seus planos de produção e sua estratégia comercial acabaram influenciando a quantidade e o tipo de produtos lácteos consumidos pela população do país.

Essa influência significou, na prática, uma diminuição do consumo de leite líquido entre as classes populares, e um aumento do consumo de derivados sofisticados, dirigidos, principalmente, às classes média e alta.

O poder da Nestlé começa ao nível da produção da matéria-prima.

Para uma empresa com tamanha força econômica, os produtores de leite formam um interlocutor fracionado e fraco. O elemento determinante da relação entre fornecedores e indústria — o preço de compra do leite - é fixado pelo Estado, de maneira a garantir a captação do sobretrabalho criado, na produção leiteira, pela empresa de transformação. Assim, os produtores não realizam sua renda fundiária, nem recebem remuneração pelo seu capital: o preço que recebem pelo leite garante, quando muito, a reprodução de sua força de trabalho familiar.

Os fornecedores de leite, apesar de proprietários de seus meios de produção, e mais particularmente da terra, foram subordinados à empresa em vários aspectos. Para eles, é particularmente difícil passar a vender seu produto para outra compradora: a dependência criada por serviços de ajuda sanitária e assistência técnica, venda de reprodutores e implementos agrícolas ao preço de custo etc. é reforçada pela rigidez das "linhas" de transporte do leite. A Nestlé oferece, também, aos seus fornecedores, uma garantia financeira que contrasta com os graves problemas enfrentados atualmente pelas empresas de laticínios de menor porte.

Através de seu controle da recepção do leite, impõe normas de qualidade e quantidade aos seus fornecedores. Para isso, é ajudada também pelo trabalho de assistência de seus técnicos. A empresa consegue transferir, assim, para os produtores, os riscos que enfrenta na comercialização de seus produtos, reduzindo seu recebimento quando não lhe convém expandir seus estoques. Sua influência é fundamental nas 
principais decisões do processo produtivo, como a quantidade de leite a ser produzida e as técnicas a serem utilizadas para isso.

Para os produtores, fica particularmente difícil abandonar a produção leiteira, apesar de sua rentabilidade pequena ou, muitas vezes, até negativa. Os mais capitalizados estão ligados a compromissos bancários que os obrigam a continuar produzindo nos mesmos termos. Aos pequenos produtores tradicionais, por sua vez, faltam alternativas que lhes garantam rendimentos regulares desse tipo.

Comprando grandes quantidades de leite nas bacias leiteiras próximas às metrópoles, o grupo suíço provocou uma redução do leite líquido disponível no mercado. De outro lado, começou a desenvolver amplas campanhas publicitárias, para provocar um novo tipo de demanda entre os consumidores. As "necessidades" do público foram redirigidas para laticínios cada vez mais sofisticados e cada vez mais caros, embora estranhos aos seus hábitos alimentares tradicionais.

O exemplo que foi tratado aqui, o da difusão do leite "maternizado", demonstrou claramente como as classes populares se tomaram as principais vítimas desse redirecionamento na nutrição de recém-nascidos: não somente expõem seus filhos a todos os perigos ligados à desnutrição, mas ainda gastam, para isso, parte importante de seu salário, tomando-se dependentes da aquisição de um produto muitas vezes supérfluo.

Como decorreu esse processo?

As análises disponíveis até hoje sobre-enfatizaram o papel das transnacionais do leite, culpando-as de desenvolver amplas campanhas publicitárias entre populações desprevenidas e "indefesas". Essa atuação, no entanto, deve ser vista dentro do quadro mais amplo da expansão do capitalismo no Terceiro Mundo: integra-se no movimento geral de acumulação do capital industrial e da evolução ideológica dele decorrente.

Esse processo depende da criação de novas necessidades, dirigidas para produtos com valor agregado cada vez maior.

Como a Nestlé foi muito criticada por suas campanhas publicitárias "abusivas", teve de tornar sua influência sobre os consumidores mais sutil: atualmente, são os profissionais de saúde os principais intermediários na difusão de sua ideologia e de seus produtos infantis.
Com a difusão do leite em pó "maternizado" entre mulheres capazes de alimentar seus filhos de maneira natural e autônoma, a empresa acabou reforçando a integração das classes populares no sistema capitalista de distribuição e de consumo. Quanto ao Estado, sua omissão quase total somente pôde favorecer esse processo.

Utilizando seu importante poder econômico, a empresa redirecionou, em seu favor, os setores de produção e de consumo de produtos lácteos, acabando, mais uma vez, com dois mitos ainda vigentes entre certos setores da sociedade brasileira: o da "independência" dos produtores rurais e o da "liberdade" dos consumidores.

Seria ingenuidade acreditar que a Nestlé possa perseguir outros objetivos além da extensão de seus mercados e de seu lucro. Não se trata de culpar as empresas transnacionais por este comportamento, que corresponde às suas necessidades dentro do processo de acumulação capitalista. Tratase, porém, de chamar a atenção para a gravidade desta evolução, tão complexa e presente em aspectos tão diversos da vida econômica e cultural do país. É preciso ser consciente da amplitude do fenômeno que está ocorrendo, tanto no campo quanto na cidade: a cada dia que passa, nossa dependência está crescendo, pela imposição de novos modelos produtivos e dos modelos culturais correspondentes.

Este trabalho tentou investigar alguns aspectos específicos da evolução citada, na esperança de que as informações recolhidas possam ser utilizadas dentro de uma luta mais ampla, que deverá ser desenvolvida a nível econômico, político e cultural. 


\section{Bibliografia citada}

Aragão, N., "O aleitamento ao seio em uma comunidade industrial. Inquérito sobre causas do desmame precoce na população infantil atendida pela Fundação de Assistência à Infância de Santo André”, in Amamentação materna, $2^{\circ}$ curso de temas atuais de perinatologia do Hospital Israelita Albert Einstein, 1977.

Arbeitsgruppe Dritte Welt Bern, Exportinteressen Gegen Muttermilch. Hamburgo, Rowohlt, 1976.

Assistência Nestlé aos Produtores de Leite/ANPL, $1^{a}$ pesquisa por amostragem das condições existentes nas fazendas que nos fornecem leite (mimeog.). Nestlé, 1968. Assistência Nestlé aos Produtores de Leite/ANPL, $2^{a}$ pesquisa por amostragem das condições existentes nas fazendas que nos fornecem leite (mimeog.). Nestlé, 1973.

Barbosa Filho, J., "O problema do leite maternizado (desnutrição comercialogênica)”, in Revista Médica HSE, 29(3), 1977, pp. 119-24.

Bardin, L., Les mécanismes idéologiques de la publicité. Paris, Délarge, 1977. Brasil Industrial. São Paulo, Ed. Banas, 1975 e 1977-1978.

Campos Júnior, D., "Evolução da prática do aleitamento materno em pequena comunidade de hábitos rurais. Estudo retrospectivo", in Jornal de Pediatria, v. 45 (5), 1978, pp. 333-42.

Castro, A.C., As empresas estrangeiras no Brasil, 1830-1913 (mimeog.). Campinas, UNICAMP, dissertação de Mestrado, Depto. de Economia, 1976.

Castro Filho, A., Regras de alimentação no primeiro ano de vida, [s/e], 1974.

Castro Filho, A., Alimentação infantil: orientação prática, [s/e], 1977.

Cicobra/Nestlé, 50 anos de uma presença familiar: 1921-1971, [s/e], [s/d].

Cornaton, M., "La publicité", in Economie et Humanisme, setembrooutubro de 1968.
Dias, L. Ribeiro, “A "ciência' para impor o leite em pó, in Movimento, 28 de janeiro de 1980, pp. 12-13.

Faure, C., "La production paysanne et l'exploitation capitaliste", in L'homme et la société, n9 45-46, julho-dezembro de 1977, pp. 51-68.

Fredericq, A., "O ciclo do leite", in Cadernos do CEAS, n" 66, março-abril de 1980 .

FIBGE, Censo agrícola, Minas Gerais, 1950 e 1960, Ed. IBGE/SEPLAN.

FIBGE, Censo agropecuário, Minas Gerais, 1970.

FIBGE, Censo agro pecuário, Brasil, 1970.

FIBGE, Sinopse preliminar do censo agropecuário de 1975, Minas Gerais, 1977.

Guia Interinvest: o Brasil e o capital internacional, 1975-76. Rio, Ed. Interinvest, 1975.

Hairy, D., Perraud, D., Saunier, P., e Schaller, B., "Quelques réflexions sur le prélèvement et l'accumulation dans la sphere agro-alimentaire", in Economie et sociétés, v. 7, n¹1-12, novembro-dezembro de 1973, pp. 2.411-29.

Iffland, C. e Stettler, A., Les investissements industriels Suisses au Brésil. Lausanne, Centre de Recherches Europeennes, 1973.

The Infiltration of the UN System by Multinational Corporations. Excerpts from Internal Files (mimeog.). Erklärung von Bern, Zurich, Ropress, [s/d].

Jelliffe D., e Jelliffe E., Human milk in the modern world. Psychosocial, nutritional and economic significance. Oxford, Oxford University Press, 1979.

Kautsky, K., A questão agrária. Porto, Portucalense, 1972.

Klaus, M.H. e Kennell, J.H., La relación madre-hijo. Impacto de la separación o pérdida prematura en el desarrollo de la familia. Buenos Aires, Ed. Médica Panamericana, 1978. 
Kucinski, B. e Ledogar, R.J., Fome de lucros. Atuação das multinacionais de alimentos e de remédios na América Latina. São Paulo. Brasiliense, 1976 (cap. IX: "Receita para a subnutrição").

Lappe, F. Moore e Collins, J., Food first: Beyond the myth of scarcity. Boston, Houghton Mifflin Co., 1977.

Martins Filho, J., "Aspectos pediátricos", in Amamentação materna, 20 curso de temas atuais de perinatologia do Hospital Israelita Albert Einstein, 1977.

Moricochi, L. et al., "Situação da pecuária leiteira em São Paulo", in Agricultura em São Paulo. Instituto de Economia Agrícola, 1973, v. I e II.

Muller, M., The baby killer. Londres, War on Want, 1974.

Nestle S.A., Présence de Nestlé dans les pays en voie de développement. Vevey, 1975.

Organização Mundial da Saúde/UNICEF, A boa iniciação nutricional. Como melhorar a nutrição de mães e crianças pequenas. Reunião conjunta OMS/UNICEF sobre alimentação de lactentes e crianças na primeira infância. Genebra, 9-12 de outubro de 1979.

Passos Guimarães, A., A crise agrária. Rio, Paz e Terra, 1979.

Pires, E. e Bielchowsky, R., Estrutura industrial e progresso técnico na produção de laticínios (mimeog.). Rio, FINEP/Centro de Estudos e Pesquisas, 1977

Plank e Milanesi, "Infant feeding and infant mortality in rural Chile", in Bull of the World Health Organization, 48, 1973, p. 208.

"Quem é quem na economia brasileira", edição especial da revista Visão. São Paulo, 1972 a 1977.

Rastoin, J.L., Croissance des firmes agro-alimentaires multinationales (mimeog.). Montpellier, Institut Agronomique Méditerraneen, [s/d].

Rastoin, J.L., Les cent premiers groupes mondiaux de l'industrie agroalimentaire. Montpellier, Institut Agronomique Méditerraneen, Série "Etudes et Documents", no 12, 1976.
Sampaio, P., Presença do capital estrangeiro na agricultura brasileira (mimeog.). São Paulo, CEBRAP, 1977.

Schweizerische Arbeitsgruppen fur Entwicklungspolitik, Nestlé ist Verantwortlich for den Tod Tausender von Babys. Berna, 1974

Servolin, C., "L'absorption de l'agriculture dans le mode de production capitaliste", in L'univers politique des paysans. Paris, Presses de la Fondation Nationale des Sciences Politiques, Cahiers de la Fondation Nationale des Sciences Politiques, no 148, 1972, pp. 41-77.

Silva, P.S.L. de Andrade e, "Aleitamento ao seio em uma comunidade de favelas", in Amamentação materna, $2^{\circ}$ curso de temas atuais de perinatologia do Hospital Israelita Albert Einstein, 1977.

Sorj, B., Estado e classes sociais na agricultura brasileira. Rio, Zahar, 1980.

Souza, F.A. Salles de, A regulamentação do mercado fluido $e$ a transformação tecnológica da pecuária de leite no Brasil (mimeog.) Universidade de Brasília, Depto. de Economia, 1979.

Ulloa, A. Garcia, Alimentação de crianças menores de 1 ano de idade, pertencentes a dois grupos socioeconômicos diferentes, atendidas por um Centro de Saúde da Capital do Estado de São Paulo, dissertação de Mestrado, Depto. de Nutrição da Faculdade de Saúde Pública da USP. São Paulo, [s/d].

Veiga, P.L., "Saúde e ideologia", in Opinião. Rio, 6 de agosto de 1976. 